UNIVERSIDADE DE BRASÍLIA

INSTITUTO DE CIÊNCIAS HUMANAS

PROGRAMA DE PÓS-GRADUAÇÃO EM HISTÓRIA

Juliano Medeiros

POR DENTRO DA ORDEM:

Os comunistas na Assembleia Constituinte de 1946 
Juliano Medeiros

POR DENTRO DA ORDEM:

Os comunistas na Assembleia Constituinte de 1946

Dissertação apresentada ao Departamento de História do Instituto de Ciências Humanas da Universidade de Brasília para a obtenção dos créditos correspondentes à disciplina de Dissertação em História.

Orientadora: profa. Dra. Lucília de Almeida Neves Delgado 
FOLHA DE APROVAÇÃO

Juliano Medeiros

\section{POR DENTRO DA ORDEM: \\ Os comunistas na Assembleia Constituinte de 1946}

Dissertação apresentada ao Programa de Pós-Graduação em História da Universidade de Brasília como parte dos requisitos para obtenção do grau de Mestre em História.

Aprovado em 22 de fevereiro de 2016.

\section{BANCA EXAMINADORA:}

Profa. Dra. Lucília de Almeida Neves Delgado (Orientadora)

Prof. Dr. Jaime de Almeida (História - UnB)

Profa. Dra. Maria Salete Kern Machado (Sociologia e Direitos Humanos - UnB) 


\section{AGRADECIMENTOS}

Este trabalho não teria sido possível sem as oportunidades oferecidas pelo Estado brasileiro a este filho de um operário e de uma dona de casa. Os quase vinte anos de estudos realizados integralmente em instituições públicas e gratuitas pavimentaram o caminho do interior do Rio Grande do Sul à formação de excelência oferecida por duas das melhores instituições de ensino superior do país - a Universidade Federal do Rio Grande do Sul e a Universidade de Brasília - nas quais graduei-me e cursei o Mestrado em História. Começo, portanto, agradecendo ao corpo docente, aos técnicos administrativos e funcionários em geral de todas as instituições públicas que me acolheram durante estes anos. Oxalá mais filhos de operários e de donas de casa possam ter as oportunidades que o Estado brasileiro me ofereceu.

Agradeço também aos amigos e amigas que acompanharam nesta jornada pela história política do Brasil do século XX, em especial aos colegas Rafael Nascimento e Paulo Otero. Agradeço aos colegas de trabalho da Liderança do Partido Socialismo e Liberdade na Câmara dos Deputados e do mandato do Deputado Federal Ivan Valente (PSOL/SP), que incentivaram desde sempre minhas atividades acadêmicas, não obstante as dificuldades acarretadas pelas recorrentes ausências, especialmente os amigos Pedro Brandão, Karina Moura, Lilian Oliveira, Robson Santiago, Alexandre Varela, Elisabete Medeiros e Tetê Monteiro, em nome dos quais estendo meu agradecimento a todos os colegas que garantem o trabalho parlamentar do PSOL na Câmara dos Deputados, sobretudo aos companheiros Ivan Valente, Edmilson Rodrigues, Glauber Braga, Chico Alencar e Jean Wyllys, nossos bravos parlamentares com quem aprendo a cada dia.

Agradeço aos dirigentes da Executiva Nacional do PSOL na pessoa do camarada Luiz Araújo, nosso presidente nacional e companheiro de todas as lutas. Agradeço ainda o aprendizado constante dos amigos Aldenor Júnior, Gilberto Maringoni, Toninho Andrade, Maria José Maninha, Cid Benjamin, Luiz Arnaldo e Milton Temer, que relevam minhas incontáveis falhas e deficiências para seguir depositando suas confianças neste aprendiz do intelectual militante. Aos amigos do dia-a-dia, Kauê Scarim, Raphael Sodré e Mateus Ut_ız, meus agradecimentos pela paciência e apoio constantes.

Agradeço aos meus familiares que, apesar da distância, acompanham cada conquista com alegria. À Juliana Maia, mãe da minha pequena Clara, pela compreensão em relação à distância e ausência. Agradeço à professora Lucília de Almeida Neves Delgado, extraordinária historiadora brasileira, que depositou sua confiança em minha capacidade de lidar com as adversidades que acompanharam o desenvolvimento deste trabalho e, em nome dela, a todo o 
corpo docente do Programa de Pós-Graduação em História da Universidade de Brasília. Além dela, endereço meus agradecimentos à banca examinadora, composta pelos professores Jaime Almeida e Maria Salete Kern Machado, pela disponibilidade e interesse em tomar parte neste importante momento de minha formação acadêmica.

Agradeço, por fim, a Nádia Junqueira Ribeiro, grande incentivadora de todos os meus desafios acadêmicos nos últimos anos - da conclusão da graduação à aprovação na seleção do doutorado. Sua presença fez a jornada mais leve, mais bonita e mais engrandecedora. Sem ela eu jamais teria chegado tão longe. Sem ela jamais teria aprendido tanto sobre mim mesmo.

A essas e outras pessoas que, direta ou indiretamente, consciente ou inconscientemente, tornaram este empreendimento intelectual possível, endereço o meu muito obrigado. 
Os homens fazem a sua própria história, mas não a fazem como querem, não a fazem sob circunstâncias de sua escolha e sim sob aquelas com que se defrontam diretamente, legadas e transmitidas pelo passado.

Karl Marx O 18 Brumário de Louis Bonaparte 


\title{
RESUMO
}

A presente dissertação analisa a trajetória do Partido Comunista do Brasil (PCB) durante os trabalhos da Assembleia Constituinte de 1946. Para tanto, são abordados os antecedentes que permitiram a reorganização e legalização do partido, as eleições de 1945 e o perfil da bancada eleita naquele ano. Utilizando os registros disponíveis nos arquivos da Câmara dos Deputados acerca dos trabalhos da Constituinte, além de documentos oficiais do PCB, buscamos reconstituir a dinâmica no interior da bancada comunista, sua relação com as instâncias do partido, com as demais agremiações partidárias e com o governo do General Eurico Gaspar Dutra. Destacamos, ainda, as posições políticas do PCB no contexto da democratização dos anos 1940 e a política de "união nacional" desenvolvida pelo partido, a partir de sua II Conferência Nacional (1943), além das transformações vividas pelo partido durante sua adaptação à dinâmica partidária legal. Por fim, dedicamos parte deste trabalho a desenvolver algumas hipóteses sobre a relação entre as dimensões político-organizativas e seu impacto sobre o funcionamento da bancada comunista, bem como sobre a orientação política geral do PCB, explorando as formas de interação do partido com a democracia representativa de 1946.

Palavras-chave: Partido Comunista do Brasil; Assembleia Constituinte; Democracia.

\begin{abstract}
This dissertation analyzes the history of the Communist Party of Brazil (PCB) during the proceedings of the Constituent Assembly of 1946. It thus explores the background that led to the reorganization and registration of the party, the 1945 elections, and the profile of the chosen countertop that year. Using the records available in the Chamber of Deputys about the work of the Constituent and official documents of the PCB, we seek to reconstruct the dynamics inside the communist group, his relationship with instances of the party, the other party associations and the government of General Eurico Gaspar Dutra. We also highlight the PCB political positions in the context of democratization of the 1940s and the policy of "national unity" developed by the party from the Second National Conference (1943) and the transformations experienced by the party during its adaptation to the legal party dynamics. Finally, we dedicate part of this work to develop some hypotheses about the relationship between the political and organizational dimensions and its impact on the functioning of communist group as well as on the overall policy direction of the PCB, exploiting the party interaction forms with the representative democracy of 1946.
\end{abstract}

Keywords: Communist Party of Brazil; Constituent Assembly; Democracy. 


\section{LISTA DE SIGLAS}

ABI - Ação Integralista Brasileira

ANL - Aliança Nacional Libertadora

CTB - Central dos Trabalhadores do Brasil

CNOP - Comissão Nacional de Organização Provisória

CTB - Confederação dos Trabalhadores do Brasil

EUA - Estados Unidos da América

FEB - Força Expedicionária Brasileira

IC - Internacional Comunista

MUT - Movimento Unificado dos Trabalhadores

ONU - Organização das Nações Unidas

PAN - Partido Agrário Nacional

PCF - Partido Comunista Francês

PCI - Partido Comunista Italiano

PCUS - Partido Comunista da União Soviética

PDC - Partido Democrata Cristão

PDT - Partido Democrático Trabalhista

PL - Partido Libertador

POSDR - Partido Operário Social Democrata Russo

PPS - Partido Popular Socialista

PR - Partido Republicano

PRP - Partido da Representação Popular

PSB - Partido Socialista Brasileiro

PSD - Partido Social Democrático

PT - Partidos dos Trabalhadores

PTB - Partido Trabalhista Brasileiro

TSE - Tribunal Superior Eleitoral

UDN - União Democrática Nacional

UJC - União da Juventude Comunista

UNE - União Nacional dos Estudantes

URSS - União das Repúblicas Socialistas Soviéticas 


\section{SUMÁRIO}

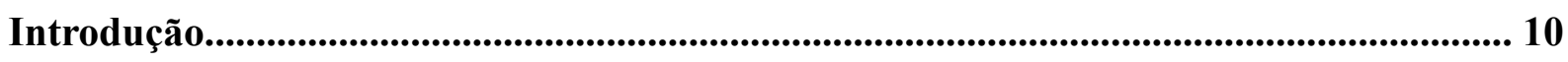

Capítulo 1 - Poder, Política e Partido na Historiografia Contemporânea....................... 18

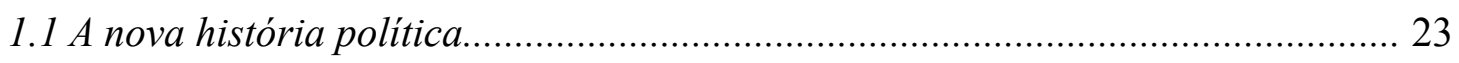

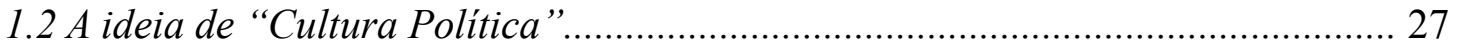

1.3 Perspectivas críticas sobre a história política.................................................... 31

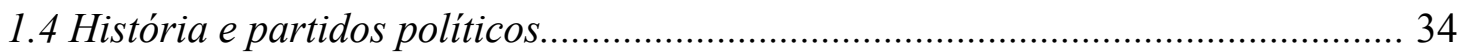

1.5 A especificidade histórica dos partidos comunistas............................................ 40

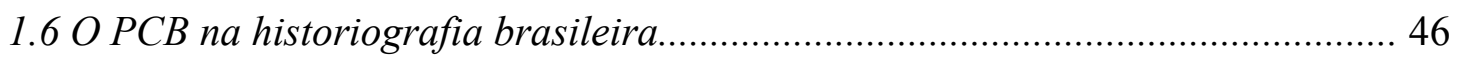

1.7 O PCB e a Assembleia Constituinte: panorama historiográfico.......................... 52

Capítulo 2 - Da tática da “união nacional” ao parlamento brasileiro............................... 56

2.1 O Brasil e o PCB num mundo em chamas.......................................................... 57

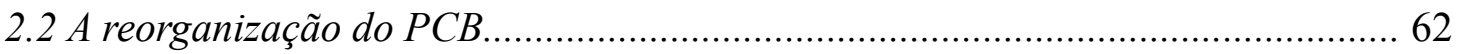

2.3 A transição de 1945: o PCB volta à legalidade ................................................. 67

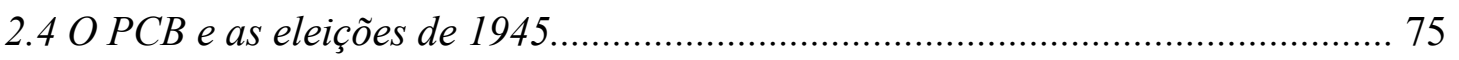

2.5 A bancada do PCB na Assembleia Constituinte: uma introdução......................... 82

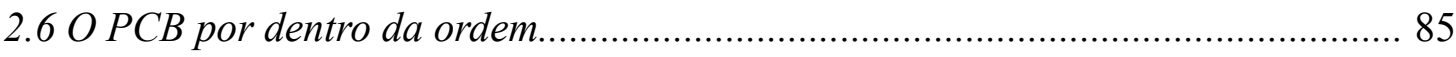

2.7 A luta por uma Constituinte democrática.......................................................... 89

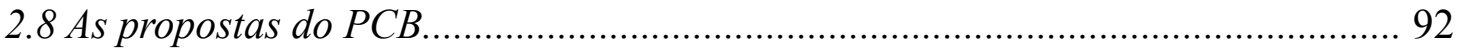

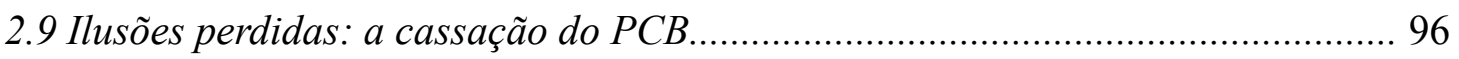

Capítulo 3 - Os comunistas e a democracia........................................................................ 101

3.1 O PCB e a democracia representativa ........................................................... 105

3.2 Dinâmica da bancada comunista na Assembleia Constituinte........................... 111

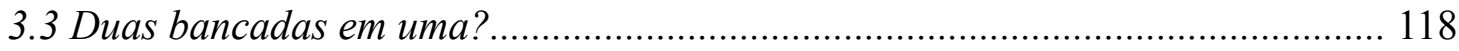

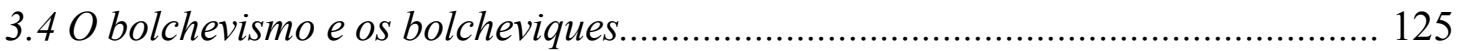

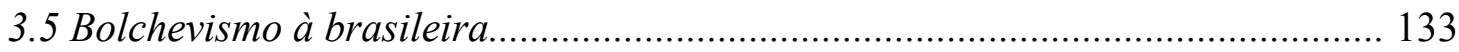

3.6 O PCB como organização de estado-maior..................................................... 141

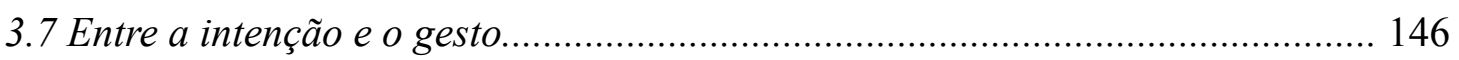

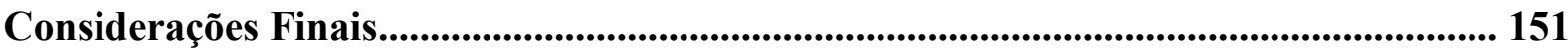

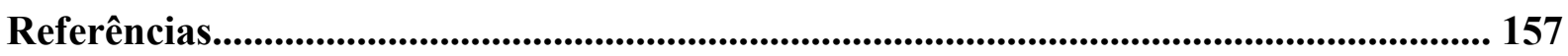




\section{INTRODUÇÃO}

É lugar comum afirmar que o PCB está entre os objetos mais vastamente analisados pela história política no Brasil. Não é para menos: até o início dos anos 1980 o partido era o principal representante, no Brasil, de uma corrente de pensamento que dividiu o mundo em dois durante a segunda metade do século XX. São dezenas de monografias, teses e dissertações, centenas de artigos, inúmeros livros publicados sobre diferentes aspectos de sua história. O interesse sobre este mítico "personagem" da política brasileira parece não ter fim. Quando pensamos que se esgotaram as possibilidades de abordagem, surgem novos estudos, biografias, filmes...

Nossa pesquisa, portanto, tem como objeto um ator vastamente trabalhado pela historiografia política no Brasil. Isso, ao contrário do que pode parecer, não torna a empreitada mais simples. Além disso, ao nos propormos a analisar a atuação do PCB em um espaço específico, a saber, a Assembleia Constituinte de 1946, nos deparamos com diferentes questões ainda hoje não resolvidas, como: a relação do PCB com a democracia representativa, seu papel no processo de democratização do pós-guerra e as razões que levaram à sua cassação, apenas para citar algumas das mais conhecidas.

Em 1946, o Partido Comunista do Brasil ${ }^{1}$ era a principal organização partidária da esquerda brasileira. Transcorridos mais de vinte anos desde sua fundação, em Niterói, no longínquo ano de 1922, o PCB se fortalecera, angariando crescentes simpatias entre os trabalhadores do campo e das cidades. Amparando-se no prestígio das experiências socialistas do leste europeu, o partido ampliou sua influência no movimento popular e manteve uma incontestável hegemonia entre as forças da esquerda, pelo menos até a fragmentação que se abateu sobre os comunistas após o Golpe de 1964. Desde então muitos estudos debruçaram-se sobre o PCB, construindo diferentes abordagens sobre a história do partido, atualizando e apresentando novas perspectivas e hipóteses. Por que, então, voltar a estudar o PCB?

O ano de 2016 marca os setenta anos da Assembleia Constituinte de 1946. Marca também os vinte e oito anos da promulgação da chamada "Constituição Cidadã" e os trinta e um anos do retorno do pleno direito à organização partidária no Brasil ${ }^{2}$. Nesse período, a

\footnotetext{
${ }^{1}$ Para manter fidelidade às fontes estudadas, optamos por utilizar o nome e a sigla que constam dos documentos do partido no período de referência, anterior, portanto, à cisão que levou ao surgimento de dois partidos comunistas: o PCB e o PCdoB, ambos reivindicando o legado anterior a 1962.

2 Emenda Constitucional $\mathrm{n}^{\mathrm{o}}$. 25, de 10 de maio de 1985, artigo 152. Disponível em: <http://www.planalto.gov.br/ccivil_03/constituicao/Emendas/Emc_anterior1988/emc25-85.htm>. Acesso em: 22, nov., 2013.
} 
multiplicação de legendas e suas variadas formas de interação com as esferas do poder estatal tornaram-se um campo fértil de estudo. Ao mesmo tempo, a chegada ao poder central de um partido cujas origens remontam a crítica à coerção violenta exercida por um Estado sempre forte sobre uma sociedade civil sempre fraca (KONDER, 1980, p. 23) estimulou a retomada dos estudos sobre a ação dos partidos socialistas e comunistas nos marcos da institucionalidade liberal. As recentes publicações sobre a história do Partido dos Trabalhadores $^{3}$, por exemplo, atestam a atualidade desta temática.

As vicissitudes da experiência petista à frente do governo federal, as mediações entre o programa partidário e a realidade concreta, as táticas para enfrentar cada conjuntura específica, os limites impostos pelo modelo de representação parlamentar e as propostas que deram origem ao partido, em síntese, as articulações entre meios e fins políticos, ampliaram o campo de possibilidades para o estudo da história dos partidos e do sistema político brasileiro nas últimas duas décadas.

Ainda são poucos os estudos, porém, que se dedicaram profundamente a um dos períodos mais controversos e ricos da vida do PCB, a saber, os poucos meses de legalidade entre 1945 e 1947 e a atuação de seus parlamentares na Assembleia Constituinte que sacramentou o fim da ditadura do Estado Novo. Com exceção da obra O PCB na Assembleia Constituinte de 1946, de Evaristo Giovanetti Netto ${ }^{4}$, e de inúmeros outros trabalhos que abordam a política geral do PCB naquele período, poucos são os estudos que se dedicaram de forma sistemática à experiência dos comunistas no parlamento brasileiro sob o governo do General Eurico Gaspar Dutra.

Ao mesmo tempo, nos últimos anos observa-se uma retomada do estudo das biografias, dando origem não só a publicações e trabalhos científicos, mas também a uma vasta produção audiovisual que se coaduna com os esforços de retomada da memória política do país através de diversas iniciativas institucionais. Assim, a pertinência do estudo dos anos de vida legal do PCB antes de sua cassação, em 1947, ganha especial relevância. Como destaca Lucília de Almeida Neves Delgado:

\footnotetext{
Em um país em que a democracia e as instituições democráticas sempre se constituíram num dramático enigma histórico, a pesquisa e os estudos das lutas e da vivência política das classes subordinadas - a quem mais de perto interessa a questão democrática - são, sem dúvida, autojustificáveis, senão uma necessidade (DELGADO, 2011, p. 22).
}

\footnotetext{
${ }^{3}$ Destaque para o estudo dos professores Lincoln Secco, História do PT, e Mauro Luís Iasi, As metamorfoses da consciência de classe: o PT entre a negação e o consentimento, além de uma série de dissertações e monografias.

${ }^{4}$ NETTO, E. G. O PCB na Assembleia Constituinte de 1946. São Paulo: Editora Novos Rumos, 1986.
} 
Entre os diversos trabalhos acadêmicos e jornalísticos dos últimos anos, destacam-se os estudos que abordam a atuação de organizações e dirigentes comunistas, como Luís Carlos Prestes, Carlos Marighella, João Amazonas, Maurício Grabois e Gregório Bezerra, muitos deles protagonistas da resistência à Ditadura Civil e Militar que se instalou em 1964. Porém, quando da cassação de seu registro, em maio de 1947, o PCB tinha quinze deputados federais e um senador, que perderam seus mandatos no ano seguinte. Onde estão os personagens dessa história? Ora, quando foi colocado novamente na ilegalidade, o partido atuava abertamente, com sedes conhecidas, uma rede de imprensa de largo alcance e uma influente atuação no movimento popular. No entanto, não demorou para que o intervalo democrático, que vigorou na América Latina imediatamente após o fim da Segunda Guerra Mundial, fosse solapado pela estratégia de contenção levada a cabo pelo governo dos Estados Unidos da América após a conferência de Potsdam ${ }^{5}$ e pela poderosa ideologia da "guerra fria".

Integrado à legalidade, com o fim do Estado Novo, o PCB tomou parte no processo de reordenamento político-institucional, buscando ampliar sua presença no aparato sindical e ocupar espaço na esfera parlamentar. Essa política resultou na eleição de uma bancada de deputados federais no pleito de 1945, composta por Carlos Marighella, Maurício Grabois, João Amazonas, Jorge Amado, Gregório Bezerra, José Maria Crispim, Joaquim Batista Neto, Osvaldo Pacheco, Abílio Fernandes, Alcides Sabença, Agostinho Dias de Oliveira, Milton Caires de Brito, Alcedo Coutinho e Claudino da Silva. Além disso, o partido elegeu Luís Carlos Prestes ao senado federal e conquistou $10 \%$ dos votos para a presidência da república. Essa bancada de parlamentares tomou parte na Assembleia Constituinte de 1946 e teve ativa atuação frente a vários temas de grande relevância nacional. Contudo, o partido enfrentou inúmeras contradições à medida que buscava articular seu papel de representante políticoinstitucional de uma classe trabalhadora cada vez mais inquieta e, assim, mantinha no Congresso Nacional os discursos em defesa da "ordem e tranquilidade", comprometendo-se cada vez mais com as regras do novo jogo da democracia representativa (SILVA; SANTANA, 2007).

Unido em torno da tática da "união nacional", que preconizava o abandono da proposta de "revolução agrária anti-imperialista" da Aliança Nacional Libertadora (ANL) dos anos 1930, em favor da união em torno de Vargas, para alcançar a paz e a democracia, o PCB marchou na Assembleia Constituinte, lutando desde o início pela consolidação de uma

\footnotetext{
${ }^{5}$ A Conferência de Potsdam, na Alemanha, ocorreu entre julho e agosto de 1945. Nela os aliados vitoriosos na Segunda Guerra Mundial (EUA, Inglaterra e URSS) estabeleceram os marcos da nova ordem mundial pósguerra.
} 
democracia liberal típica. Esse esforço, no entanto, não pode esconder diferenças importantes no interior da bancada comunista. Analisando as fontes disponíveis, notamos a existência de “duas bancadas em uma". De um lado, um grupo de deputados mais atuante, responsável pela maioria das emendas do PCB ao projeto de Constituição, que participou das principais comissões de trabalho da Constituinte e realizou a maioria dos discursos e encaminhamentos em nome dos comunistas, formada pelos intelectuais e pelos deputados oriundos das classes médias. De outro, um grupo mais discreto e menos atuante, embora majoritário, formado pelos deputados de origem operária. Mas a que se devia essa dinâmica de funcionamento excludente e antidemocrática da bancada comunista, que reproduzia uma inusitada divisão entre trabalho manual e intelectual nas suas atividades parlamentares?

Nossa hipótese busca atestar a relação entre a divisão da bancada comunista em duas e os padrões organizativos assimilados pelo PCB, ao longo dos anos de 1930, durante o processo de "bolchevização" dos partidos comunistas em todo o mundo. De acordo com essa hipótese, ao adotarem um modelo de organização centrado em determinados pressupostos teóricos e políticos, o PCB aprofundou, em seu interior, um fosso já natural na estrutura social brasileira entre "letrados" e "não letrados". Diante disso, utilizando o modelo analítico de Daniel Aarão Reis Filho sobre as “organizações de estado-maior”, buscaremos demonstrar ao longo deste trabalho os mecanismos de coesão que sustentaram uma estrutura de funcionamento antidemocrática no partido. Estrutura que se refletiu na atuação dos deputados comunistas na Assembleia Constituinte tais como, o "complexo de dívida" para com o partido, ente que liberta os militantes das tarefas", que mantém os militantes sob permanente estado de tensão; a "celebração da autoridade", muitas vezes transformada em culto à personalidade e apologia dos chefes; a "síndrome da traição", que ronda permanentemente organizações que agem à margem da legalidade; a função legitimadora dos "modelos internacionais"; o elogio aos "intelectuais revolucionários", dentre outras. Este modelo analítico, embora proposto inicialmente para o estudo das organizações de esquerda que lutaram contra a Ditadura Militar nos anos 1960/1970, é perfeitamente aplicável à análise do PCB - bem como de qualquer outra organização tipicamente leninista - do período democrático que se inicia em 1945.

Optamos por utilizar um referencial teórico capaz de identificar as abordagens mais relevantes acerca do poder, da política e dos partidos na historiografia contemporânea, destacando as teorias disponíveis para o estudo dos partidos políticos, as principais correntes na produção de uma história política e o panorama atual dos estudos acerca do PCB na historiografia brasileira. Além disso, buscamos ancorar nosso trabalho nas contradições 
disseminadas na sociedade brasileira da época e nas representações que o PCB, a sociedade e os demais agentes políticos tinham em relação à atuação parlamentar da bancada comunista. Para tanto, além de um trabalho inscrito no campo da história política, nossa pesquisa buscou dialogar com novas abordagens surgidas ou amparadas em outros campos do conhecimento.

A história política hoje é tributária de novas abordagens estimuladas pelo trânsito de conhecimentos com outras disciplinas, como demonstram as pesquisas sobre as eleições como revelador da opinião social de um determinado momento. No que diz respeito às teorias sobre os partidos, buscaremos dialogar criticamente com as três principais abordagens que se propõem a analisar a origem e o desenvolvimento dos partidos políticos. A primeira dessas vertentes é aquela conhecida como institucional, abarcando a relação entre os primeiros parlamentos e a formação dos partidos, oferecida por Duverger. A segunda, privilegia a análise dos partidos surgidos como resultado de crises históricas, tais como os partidos socialistas no final do século XIX ou os partidos democratas-cristãos no século XX, que evoluíram de acordo com as necessidades das classes trabalhadoras até o processo de “oligarquização", representada pela obra de Robert Michels. E, por fim, a terceira vertente, oferecida por Antônio Gramsci, a partir da qual os partidos se relacionam organicamente com o processo de modernização política e social, como elementos constituintes da sociedade política (o Estado) e da sociedade civil (as instituições não governamentais que disputam suas posições fora das esferas estatais de poder).

Consideramos, assim como Gramsci, que uma história dos partidos políticos só pode ser feita numa perspectiva panorâmica, isto é, levando-se em conta que essa é a história de grupos sociais que "não são isolados: têm amigos, afins, adversários, inimigos" e que "só do quadro complexo de todo o conjunto social e estatal - e frequentemente com interferências internacionais - resultará a história de um determinado partido" (GRAMSCI, 1976, p. 24).

Este trabalho está, portanto, dividido em três capítulos. O primeiro, busca exatamente situar o recorte teórico-metodológico de nossa pesquisa no contexto das discussões acerca das noções de "poder" e "política" nos estudos históricos; abordar as principais alternativas teóricas e metodológicas para o estudo dos partidos políticos, localizar a importância do PCB na historiografia brasileira, as principais abordagens possíveis para o estudo do partido e as pesquisas desenvolvidas acerca da participação do PCB na Assembleia Constituinte de 1946. Em resumo, o primeiro capítulo pretende apresentar um panorama das opções teóricas e metodológicas, recortando o objeto e destacando suas possíveis abordagens. Não é uma estrutura usual nos dias de hoje, mas nos parece colaborar com a síntese que procuramos 
realizar entre uma abordagem mais propriamente descritiva e as discussões teóricas sobre a política do PCB no período estudado.

No segundo capítulo nos dedicamos a apresentar os contornos gerais da política de "união nacional"; o processo de reorganização do partido, a partir da Conferência da Mantiqueira, e as divergências que lá surgiram; a legalização do PCB e sua participação no processo eleitoral de 1945. Em seguida, nos dedicamos a apresentar, em linhas gerais, as características da Assembleia Constituinte e a atuação da bancada comunista no contexto de adversidades permanentes criadas pelo governo Dutra e seus representantes - amplamente majoritários - no interior da Constituinte; os projetos de lei e as principais batalhas travadas pelo PCB. Dedicamos, ainda, parte do segundo capítulo a apresentar o perfil dos constituintes eleitos pelo partido, bem como as características da bancada (escolaridade, idade, profissão etc.) com vistas a fundamentar as discussões que desenvolveremos no terceiro capítulo. Destacamos também o empenho do PCB em assegurar uma Constituinte democrática e as dificuldades impostas pelos demais partidos e pela imprensa em geral. Por fim, dedicamos algumas páginas ao processo de cassação do PCB que levou o partido à ilegalidade em março de 1947 e seus efeitos sobre a bancada comunista no parlamento brasileiro.

No terceiro capítulo buscamos realizar a síntese entre as discussões de caráter historiográfico sobre o estudo dos partidos políticos e a trajetória do PCB entre sua reorganização, marco inicial da adoção da tática de "união nacional", e seu retorno à ilegalidade, poucos anos depois. Para tanto, começamos apresentando as diferentes abordagens sobre o processo de cassação do registro do PCB e como elas, cada qual à sua maneira, trazem consigo diferentes perspectivas sobre a relação do partido com a democracia e a institucionalidade criada pela limitada democratização de 1945.

Começamos pela questão de fundo que se apresenta em diversas abordagens historiográficas, que busca compreender em que medida os comunistas estavam realmente comprometidos com a construção de um sistema democrático em 1945. Negando as perspectivas psicologizantes do partido (que atribuem ao PCB características como ingenuidade, cinismo, otimismo etc.) buscamos abreviar o abismo construído por parte da historiografia entre um sujeito coletivo organizado em torno de um projeto político e a realidade social historicamente constituída ao seu redor.

Em seguida, nos dedicamos a abordar a complexa relação do PCB com a democracia, recorrendo mesmo a interlocutores de outras áreas do conhecimento, como Norberto Bobbio. Questionando a associação automática entre democracia partidária e compromisso com a institucionalidade democrática, tentamos demonstrar como, na verdade, as limitações que o 
PCB demonstrou sobre a leitura da realidade estão assentadas mais numa superestimação do potencial que aquela transição democrática oferecia que numa suposta ausência de "compromisso" democrático, não importando se atribuído à "natureza" dos partidos comunistas ou ao PCB especificamente.

Ao analisar detalhadamente a divisão entre "letrados" e "operários" no interior da bancada comunista, constatamos, a partir dos anais da Assembleia Constituinte, que a hipótese se confirma na quantidade de iniciativas legislativas tomadas por cada uma das bancadas, bem como pela hostilidade dirigida pelos deputados conservadores sobretudo aos deputados de origem operária no decorrer dos trabalhos da Constituinte. Confirmada a hipótese, buscamos aquelas que nos parecem ser as razões últimas que levaram a bancada a reproduzir uma divisão exógena, importada do partido. Por sua vez, encontramos nas origens do movimento comunista em geral, e dos partidos comunistas em particular, as pistas que nos levam a compreender a gênese das chamadas "organizações de estado-maior". Com a colaboração do modelo analítico oferecido, pudemos atestar as características dessas organizações reproduzidas no PCB: como partido leninista afiliado à III Internacional (a Internacional Comunista), os comunistas brasileiros dos anos 1940 herdaram um partido resultante de um processo de "bolchevização" que buscou homogeneizar todas as organizações comunistas à imagem e semelhança de seu homônimo soviético. Neste longo percurso histórico, cuja origem reside nos fundadores do movimento comunista e passa tanto pela ruptura entre bolcheviques e mencheviques quanto pela construção do "partido proletário de novo tipo" (como modelo a ser seguido), está a gênese do padrão organizativo excludente e antidemocrático encontrado em muitas organizações de estado-maior.

Seguindo o objetivo de evitar a análise a partir daquilo que o PCB "deveria ter feito" (BRANDÃO, 1997, p. 16), dedicamos a parte final do referido capítulo a demonstrar que o PCB, apesar de suas enormes limitações, muitas delas impostas por condicionantes alheios ao partido, aportou uma contribuição decisiva ao limitado processo de democratização, demonstrando um firme compromisso - pouco importa se sincero ou não - ao processo de construção de um sistema político democrático e um sistema econômico e social que assegurasse os mais amplos direitos sociais, mesmo sob os limites da institucionalidade liberal. O forte reformismo do $\mathrm{PCB}$, portanto, não pode ser tomado em comparação à revolução que muitos acreditam ser o dever dos comunistas promover: tal reformismo era possivelmente a posição mais radical que um partido, nos marcos da legalidade instaurada em 1945, poderia adotar para alargar os limites daquilo que as elites nacionais estavam dispostas a conceder. 
Nossa conclusão aponta no mesmo sentido. Não buscamos “absolver" ou “condenar" o PCB, como parte da historiografia fez especialmente a partir dos anos 1980. Nossa intenção é demonstrar a força dos condicionantes externos sobre as organizações políticas e como determinadas opções organizativas podem proteger ou tornar vulnerável mesmo o mais sólido dos partidos.

Utilizamos como fontes, além dos jornais da época, resoluções do PCB e documentos oficiais, sobretudo aqueles disponibilizados pela Câmara dos Deputados. A digitalização completa dos Anais da Assembleia Constituinte de 1946 poupou-nos muitas horas de trabalho sobre livros pesados e amarelados. Da mesma forma, a digitalização dos Diários da Constituinte permitiu compreender melhor a dinâmica dos trabalhos legislativos e ter acesso a informações complementares que foram preciosas para a execução deste trabalho. A extensa bibliografia sobre o PCB, descrita ao final do primeiro capítulo, também foi indispensável para o desenvolvimento desta pesquisa, bem como as obras de Sérgio Soares Braga, Quem foi quem na Assembleia Constituinte de 1946, editada pela Câmara dos Deputados em 1998, e de Evaristo Giovanetti Netto, O PCB na Assembleia Constituinte de 1946, publicada em 1986 pela editora Novos Rumos, principal estudo até hoje sobre a presença dos comunistas naquele espaço legislativo. Da mesma forma, foram fontes indispensáveis os documentos do PCB, na época sistematizados por Edgard Carone em $O P C B$ (1943-1964), segundo volume, publicado pela editora Difel em 1982, e por Moisés Vinhas em O Partidão (Ed. Hucitec, 1982). A vasta quantidade de documentos oficiais, tais como leis, decretos e decisões judiciais, também digitalizadas nos últimos anos, facilitaram enormemente o processo de pesquisa desenvolvido ao longo deste trabalho.

Considero que a História do $\mathrm{PCB}$, que se mistura à própria História do Brasil, de suas instituições e de seu sistema político, ainda tem muito a nos dizer. Despindo-nos da condição de "juízes da história" e lançando um olhar compreensivo sobre os homens e mulheres que se dedicaram à tarefa de transformar o Brasil a partir de suas crenças e valores, àqueles e àquelas que perderam suas vidas, afastaram-se de seus entes queridos, foram presos, torturados e perseguidos - não como indivíduos tomados por uma ideologia estrangeira incompatível com o povo brasileiro -, olhando para estes poderemos, quem sabe, compreender a importância que o PCB e os comunistas em geral deram à formação do Brasil moderno. Este trabalho tem como objetivo ser uma singela contribuição a tal esforço. 


\section{CAPÍTULO 1}

\section{PODER, POLÍTICA E PARTIDO NA HISTORIOGRAFIA CONTEMPORÂNEA}

Partido Comunista do Brasil (PCB) foi objeto de incontáveis estudos desde sua criação, em 1922. Portanto, tomá-lo como tema principal deste trabalho exige uma série de cuidados adicionais. Primeiro, pela variedade de abordagens historiográficas possíveis; segundo, pela amplíssima bibliografia disponível sobre suas diferentes fases históricas; e terceiro, pelas muitas perspectivas teóricas que cercam, atualmente, o estudo dos partidos políticos em geral - e dos partidos comunistas em particular. Consideramos possível, no entanto, combinar uma abordagem, senão original, pouco desenvolvida para o estudo da história do PCB a uma opção teórico-metodológica condizente com o desafio de localizar corretamente o lugar dos comunistas brasileiros no processo de democratização da política e das instituições nacionais entre 1945 e 1947. Para tanto, buscaremos apresentar no presente capítulo um breve panorama das principais abordagens teóricas entre política, história e poder, definindo nossas opções metodológicas para o estudo do PCB, suas especificidades históricas e sua posição na historiografia brasileira, sem o qual se torna impossível justificar a escolha de nosso objeto.

Ademais, importa destacar que este trabalho se situa no campo da história política. No entanto, a variedade de perspectivas que o objeto "político" permite abarcar exige que situemos a condição atual dos estudos que se propõem a analisar os fenômenos políticos em sua dimensão histórica. Sendo assim, começaremos com uma breve digressão acerca do lugar ocupado pela política desde o surgimento da História como disciplina.

A história política foi a modalidade mais significativa da historiografia do século XIX, período da consolidação tanto dos Estados-Nação no mundo europeu e americano quanto do estabelecimento de tradições propriamente nacionais. Seus autores supunham que uma descrição fiel dos fenômenos do Estado e de seus agentes corresponderia à reconstituição exata do processo histórico (MENDONÇA; FONTES, 2012, p. 55). Também nesse período, a História ganhou um novo sentido: o de conhecimento controlável e demonstrável, chamado científico, cognoscível e explicável a partir da utilização de métodos e teorias. A História cujo renascimento se organiza e se estrutura na passagem do Iluminismo para o Romantismo, e se 
consolida ao longo do século XIX nos cenários do positivismo, do historicismo e das escolas metódicas, é a História como ciência. (MARTINS, 2010, p. 9).

Neste percurso, foram estabelecidos parâmetros tidos como indispensáveis para que o conhecimento histórico pudesse ser considerado "confiável". Nessa época foram produzidos os primeiros grandes tratados, que buscavam normatizar a produção historiográfica, sobretudo na França e na Alemanha, com Buchez, Ranke, Droysen, chegando até Langlois, Seignobos e Karl Lamprecht. Com diferenças importantes entre eles, esses pioneiros da história-ciência tinham em comum a crença na possibilidade de um conhecimento histórico objetivo, imune às influências, paixões e opiniões dos indivíduos que o produziam. Para alcançar esse objetivo, recomendavam manter-se a máxima fidelidade às fontes, que exprimiriam em si mesmas os acontecimentos históricos. O historiador, assim, seria um especialista na tradução dos fatos registrados nas fontes para a forma de conhecimento histórico, de acordo com o paradigma das ciências naturais, de mínima influência do sujeito sobre o objeto. Com isso, escassas dúvidas pairavam sobre o papel central que a personalidade dos grandes líderes e estadistas exerciam sobre a história; os temas históricos giravam em torno de batalhas, relações internacionais, decisões ou hesitações dos ocupantes dos principais postos políticos (MENDONÇA; FONTES, 2012, p. 55). Esse atrelamento ao poder constituído acabou por caracterizar a História como um instrumento útil à difusão da ideologia das classes sociais hegemônicas, elevando seus heróis e construindo uma memória histórica que privilegiava as elites.

Contudo, não tardaria para que essa forma de encarar a produção do conhecimento histórico fosse colocada em xeque. Fora do ambiente acadêmico, outras perspectivas teóricas já questionavam duramente aquela produção historiográfica. É notório o exemplo de Georges Plekhanov, pioneiro do marxismo na Rússia, que dedicou boa parte de sua obra a criticar as perspectivas metódicas e historicistas presentes na França e Alemanha no final do século $\mathrm{XIX}^{6}$. Porém, é no decorrer do século seguinte que a hipervalorização da história política e o predomínio dos métodos descritivos serão mais fortemente combatidos. René Rémond, influente pensador das novas abordagens do político na disciplina histórica, destaca a surpresa ao ver perpetuada a "caricatura de uma história política cada vez mais distanciada da realidade da disciplina histórica". O historiador francês aponta que:

\footnotetext{
${ }^{6}$ Plekhanov desenvolve, ao problematizar o lugar relegado aos sujeitos na produção historiográfica da época, uma crítica absolutamente original às opções teórico-metodológicas dos historiadores de seu tempo a partir da abordagem materialista-dialética da História. Para mais informações sobre a crítica de Plekhanov ao historicismo, cf. PLEKHANOV, G. A Concepção Materialista da História. Rio de Janeiro: Paz e Terra, 1978.
} 
Durante séculos, a chamada história política - a do Estado, do poder e das disputas por sua conquista ou conservação, das instituições em que ele se concentrava, das revoluções que o transformavam - desfrutou junto aos historiadores de um prestígio inigualado devido a uma convergência de fatores. Talvez eles a achassem mais fácil de reconstituir por basear-se em fontes que tinham a dupla vantagem de ser regularmente constituídas - já que estabelecidas por uma administração cuja função era operar por meio de textos que deixavam um vestígio escrito - e estar classificadas e conservadas, e, portanto, acessíveis em um momento posterior. No Antigo Regime, a história era naturalmente ordenada tendo em vista a glória do soberano e a exaltação da monarquia. As revoluções que derrubaram os regimes monárquicos não destronaram a história política de sua posição preeminente, apenas mudaram seu objeto. Em vez de fixar-se na pessoa do monarca, a história política voltou-se para o Estado e a nação, consagrando daí em diante suas obras à formação dos Estados nacionais, às lutas por sua unidade ou emancipação, às revoluções políticas, ao advento da democracia, às lutas partidárias, aos confrontos entre as ideologias políticas. (RÉMOND, 2003a, p.15).

Notamos, pois, que as mudanças sociais ocorridas no processo de amadurecimento da História enquanto disciplina não foram suficientes para alterar a predominância do político sobre as demais dimensões do conhecimento histórico. Só nas primeiras décadas do século $\mathrm{XX}$, quando uma nova geração de historiadores se insurge contra a hegemonia do político, privilegiando os estudos sobre o trabalho, a produção, as trocas, as técnicas, a cultura, enfim, sobre o social e o econômico, é que o político perde força. Para esta nova geração, a história política dava uma atenção desmedida aos humores e às vontades dos dirigentes políticos. Caía no psicologismo e perdia-se em conjecturas sobre as suas verdadeiras intenções, como se estas pudessem mudar o curso de uma história que é essencialmente conduzida por movimentos impessoais e anônimos, cuja amplidão transcende às escolhas individuais (Ibid., p. 18). Como é comum a toda nova tradição que sente a necessidade de contrapor-se ao que considera ultrapassado, a chamada Escola dos Annales pôs abaixo o edifício daquela história política "tradicional". Porém, em que pese sua defesa de uma história-problema, por muito tempo suas abordagens não estimularam uma renovação da história política: ao contrário, bloquearam-na ${ }^{7}$. (MENDONÇA; FONTES, 2012, p. 56).

As grandes matrizes teóricas que disputaram entre si a hegemonia do pensamento científico ao longo do século XX - o marxismo e o liberalismo - num primeiro momento também dificultaram a renovação da história política. Se por um lado os Annales rechaçaram por muito tempo a dimensão do político em favor de perspectivas sociais e econômicas, por outro, teorias com grande influência no âmbito do pensamento marxiano - com destaque para

\footnotetext{
${ }^{7}$ Esta afirmação, no entanto, não deve servir para reforçar a interpretação - corrente na historiografia brasileira de que a negação do político na França tenha significado sua debacle em âmbito mundial. Na Inglaterra, Itália, Alemanha e Estados Unidos, dentre outros países, a história política, como história do poder, continuou a ser desenvolvida por diversos historiadores. (RAMOS, 2010, p. 01).
} 
o "estruturalismo" dimensão política, já que, para aquelas, esta seria apenas o reflexo das relações econômicas e sociais. Apesar disso, foi com base nessas matrizes que as ciências sociais continuaram a interpretar a realidade, ainda que convivendo com contínuas ondas de renovação.

O pensamento liberal, cujas bases remontam às obras de Locke e Hobbes, considera que a sociedade é composta de indivíduos cuja natureza suscita condutas incompatíveis com a vida em sociedade (agressividade, egoísmo etc.), razão pela qual o Estado seria a expressão de um "pacto" a partir do qual os direitos naturais tidos como fundamentais - a vida e a propriedade - estariam preservados. Longe de qualquer desígnio divino, o Estado incorporaria um poder acima da sociedade, graças ao seu temível monopólio da força e à condição de representante dos interesses "gerais" da sociedade, fruto do contrato social firmado entre governante e governados que substituiu o Estado de natureza por um Estado civil (MENDONÇA; FONTES, 2012, p. 56).

A obra de Marx e Engels, por sua vez, situa-se filosoficamente em oposição à interpretação liberal. Para eles, a sociedade não pode ser tomada como mero somatório de indivíduos que se sociabilizam exclusivamente no âmbito político, conforme supõem os teóricos liberais. Marx e Engels concluem que as relações sociais, que têm como finalidade última a reprodução material e espiritual da existência, são, em primeiro plano, relações sociais de produção. Nessa perspectiva, o Estado emerge como resultante dessas relações, encontrando as raízes de seu poder nas formas de dominação vigentes na vida social (econômica, social, cultural, política etc.). Para Marx e Engels, portanto, o Estado não seria um elemento "externo" à sociedade, como pensavam os liberais, mas produto direto das lutas sociais e da dominação de uma classe sobre as demais ${ }^{9}$.

Essas concepções - liberal e marxiana - seguem tendo enorme influência sobre as formas de conceber o Estado e o poder. Logo, não seria possível imaginar que a produção historiográfica sobre a política enquanto forma de exercício do poder ${ }^{10}$, pudesse renovar-se ignorando-as. Numa formulação precisa, Ciro Flamarion Cardoso destaca que a política poderia ser definida como a resultante - dinâmica e ao mesmo tempo sistêmica - de todos os fenômenos implicados pela conquista e pelo exercício do poder. Uma formulação inspirada na teoria machiaveliana, segundo a qual a política exprime consigo a lógica objetiva da luta pelo

\footnotetext{
${ }^{8}$ Para conhecer uma avassaladora crítica marxiana ao estruturalismo de Louis Althusser cf. THOMPSON, E.P. $A$ miséria da teoria - ou um planetário de erros. Rio de Janeiro: Zahar Editores, 1981.

${ }^{9}$ Cf. MENDONÇA; FONTES, 2012, p. 56.

${ }^{10}$ Para aprofundar a discussão acerca das dimensões do poder para o historiador cf. CARDOSO, C. F. História e Poder: uma nova história política? In: CARDOSO, Ciro, VAINFAS, Ronaldo (org.). Novos domínios da história. Rio de Janeiro: Elsevier, 2012.
} 
poder. Essa lógica, porém, não estaria em reduzir causas justas - como a verdade e a justiça ao interesse do Príncipe, mas em deixar claro que a justeza dessas causas só triunfará como resultado da melhor utilização da política como arma contra seus adversários (MORAES, 2007, p. 48).

A história política renovou-se também no bojo de uma intensa polêmica sobre as dimensões do poder. Com suas apropriações e as relações por elas geradas, com seus mecanismos de imposição e transmissão, com sua perpetuação através da ideologia, com sua organização através das redes de atores sociais e com suas possibilidades de confrontação através do fenômeno das Revoluções, é o poder o objeto que constitui mais propriamente o objeto do historiador político (BARROS, 2009, p. 5). Para uma historiografia do poder, Cardoso alerta que:

\footnotetext{
O estudo da autoridade supõe que sejam considerados pelo menos três elementos: os detentores do poder (real ou formal); o fundamento constitutivo do poder dos detentores; e o modo em que tais detentores o possam ser, o que remete à questão da dominação e suas formas. Se "política" é um termo polissêmico [...], também o é outra noção fundamental: a de poder (CARDOSO, 2012, p. 41).
}

Com isso, ele defende que a política como campo da história deve ser observada a partir do poder, dos meios pelos quais ele é exercido, dos atores implicados nas relações de dominação e nos mecanismos por eles utilizados para mantê-las eternizadas. Cardoso não ignora, portanto, que a renovação da história política foi alimentada também pelas controvérsias quanto ao lugar do poder na pesquisa histórica. Segundo ele, várias tentativas foram desatadas no sentido de desviar a ênfase da política para o poder e, então, mediante algum tipo de construção do conceito de poder que negasse propriamente em sua análise o poder estatal, “propor 'novos objetos', diferentes daqueles que se ocupa a Ciência Política. Dentre tais tentativas, a mais famosa entre nós é, provavelmente, a de Michel Foucault ${ }^{11}$, (Ibid., p. 46).

Também para Rémond, a política é a atividade que se relaciona com a conquista, o exercício e a prática do poder. Assim, os partidos são políticos porque têm como finalidade, e seus membros como motivação, a chegada ao poder. Mas Rémond destaca que não se trata de qualquer poder. Para o autor francês, “o abuso, a partir de 1968, da noção de poder e a

\footnotetext{
11 “O poder não existe. Quero dizer o seguinte: o poder não existe, em um determinado lugar, ou emanando de um determinado ponto, algo que é um poder, me parece baseada em uma análise enganosa e que, em todo o caso, não dá conta de um número considerável de fenômenos" (FOUCAULT, M. Microfisica do Poder. Rio de Janeiro: Graal, 2010, p. 248). Para o pensador francês, o poder é uma dimensão que regula as relações entre grupos e indivíduos, podendo ser sutil, móvel e de difícil caracterização, já que envolveria não apenas meios repressivos, mas também persuasivos, dificilmente percebidos pelos próprios agentes a ele relacionados.
} 
extensão de sua aplicação, desencadearam sua diluição: tudo seria relação de poder, no ensino, na família, nas relações interpessoais". Ele pergunta, então, se seriam "a escola e a família, sociedades políticas, e os conflitos de que são teatro, conflitos políticos?" (RÉMOND, 2003a, p. 444). A crítica, ainda que velada, também é direcionada às abordagens foucaultianas. A resposta de Rémond é direta: só é política a relação com o poder na sociedade global, isto é, aquela que constitui a totalidade dos indivíduos que habitam um espaço cujas fronteiras sejam precisamente políticas. E na experiência histórica ocidental, ela se confunde com a construção histórica denominada "nação", que tem como instrumento e símbolo, o Estado (Idem).

Isso não significa que outras formas de expressão do poder para além do Estado não devam ou possam ser objeto da história política. Assim como Rémond, descartamos a solução fácil de definir o político simplesmente pela determinação arbitrária das questões que fariam parte de seu domínio, como se houvesse um espaço que lhe seria exclusivo, a exemplo do que sugere a Ciência Política (Ibid., p. 442). O político não tem fronteiras naturais: ora ele se dilata, até incluir toda e qualquer realidade da vida social, ora ele se contrai. Mas ao contrário de Rémond, não acreditamos que o domínio do político possa se definir "pelas flutuações do espírito público". A clareza com que o político assume proeminência na vida dos indivíduos tem a ver com a intensidade dos conflitos que se produzem no interior das sociedades e na relação destas entre si.

Embora seja necessário considerar que o político existe por si mesmo, como realidade própria, nem por isso o historiador deve crer que o político mantenha todo o resto das relações sociais sob sua dependência, da mesma forma que é preciso considerar que o político não está a salvo de determinações externas e de pressões de todo o tipo (Ibid., p. 445).

Ao fim e ao cabo a escrita da história acaba por estabelecer escolhas que denotam determinados posicionamentos interpretativos diante do poder, entrelaçando-o inseparavelmente com a política e desvendando mudanças e continuidades. Como lembra Falcon, segue havendo duas maneiras de olharmos a relação entre história e poder: uma, que busca detectar e analisar as muitas formas que revelam a presença do poder na própria história; e outra, que questiona as inúmeras formas através das quais o poder se manifesta na produção do conhecimento histórico (FALCON, 1997, p. 97). Dos embates em torno da segunda forma de encarar o problema do poder surgiu e se disseminou no limiar do século XX uma nova história política, que enriqueceu as interpretações acerca da história dos partidos políticos. 


\subsection{A nova história política}

Nas últimas décadas inúmeras publicações atestam um novo interesse pela esfera do político, revisitado sob uma ótica diversa daquela adotada há mais de um século pela historiografia tradicional e que definia a política apenas por seu conteúdo políticoinstitucional (RÉMOND apud D'ALESSIO; JANOTTI, 1996, p. 123).

Os trabalhos de E. P Thompson, Maurice Agulhon, Jacques Le Goff, Raymond William, Marc Ferro, Jaques Julliard e René Rémond, dentre outros, apontaram um "alargamento" da compreensão do domínio do político (D’ALESSIO; JANOTTI, op.cit., p. 124). Como emergência de experiências e tensões coletivas, o político voltou a ser aspecto central em diversos trabalhos de pesquisa histórica que o colocaram no centro de suas preocupações.

Hoje se tornou lugar comum ver trabalhos que destacam a crescente valorização da história política. Esse maior interesse pelos temas do político é atribuído por alguns historiadores a uma "mudança de eixo" que colocou a democracia no lugar da revolução como tema central das preocupações acadêmicas, provocando profundas transformações nas ciências sociais em geral e na história em particular (CAPELATO, 1996, p. 161). Ao mesmo tempo, segundo Cardoso, "ao longo do século XX, a história política tendeu a abandonar as ingenuidades do narrativismo tradicional em favor de posições mais de acordo com a moderna ciência política", o que favoreceu sua renovação (CARDOSO, 2012, p. 45). Junto com isso, vimos a proposta de "deslocamento" no campo da história política para novos objetos, como os movimentos sociais, grupos minoritários e expressões culturais diversas (Ibid., p. 162).

A crítica dos Annales aos historiadores da escola metódica, que trabalhavam no tempo curto, enfatizando o evento político oficial, foi um primeiro alerta contra a ingenuidade de ver a realidade apenas a partir das aparências que o imediato oferece. É também o que sugere a noção marxiana de ideologia: aquilo que parece não é aquilo que realmente é (D'ALESSIO; JANOTTI, 1996, p. 124). Analisemos os debates mais relevantes ocorridos no processo de renovação da história política para identificarmos as diferenças de abordagem que trouxeram novos problemas a resolver.

Como vimos, a renovação da história política se deu na esteira das polêmicas envolvendo a noção de poder. Para parte dos novos historiadores políticos, o poder não seria exercido apenas pelo Estado e suas instituições, mas através de várias formas de controle violentas ou consensuais - exercidas cotidianamente, como entre membros de uma família, de uma vizinhança ou de uma comunidade falante. Redefinida desta maneira, os objetos da nova 
história política seriam todos aqueles atravessados pela "noção de poder" e não apenas aqueles diretamente relacionados com o exercício do poder estatal ou da ação dos grupos dominantes (BARROS, 2009, p. 7).

Assim, teríamos, de um lado, aqueles antigos temas que, apesar de terem sido rejeitados pela historiografia das primeiras décadas do século passado, voltam agora à tona com um novo sentido: a diplomacia, as instituições, os partidos e mesmo a trajetória de indivíduos que ocuparam lugar de destaque no exercício do poder. De outro lado, além dos temas relativos às grandes unidades políticas - o Estado e as instituições que com ele se relacionam diretamente - estão novos objetos como movimentos sociais, ideologias, símbolos, discursos e outras expressões que encarnam ou representam formas de exercício do poder. Em muitos desses temas a nova história política produziu forte interação com outros campos da História, como a cultura (Ibid., p. 107).

Relegando o Estado e os grupos dominantes a uma posição secundária, uma nova história política disseminou sua própria noção de poder, traduzida, sobretudo, a partir da chamada "história vista de baixo", voltada ao comportamento político-eleitoral de segmentos anônimos das "massas" e dos "homens comuns" em seu cotidiano, enfatizando o estudo de seus valores, práticas simbólicas e ritos. Daí a boa acolhida que tiveram conceitos como imaginário, discurso e representação, demonstrando uma crescente interação entre os historiadores políticos e a História Cultural (MENDONÇA; FONTES, 2012, p. 60).

Entretanto, o surgimento de uma nova história política não se alimentou somente das novas perspectivas oferecidas pelos chamados "culturalistas". Outros autores também contribuíram fortemente com sua renovação. Após a Segunda Guerra Mundial, cresceu enormemente a circulação de diversas obras sugerindo uma retomada dos temas políticos. No campo do pensamento marxiano ocidental ${ }^{12}$, exerceram grande influência as obras de Gramsci, Luckács, além da chamada Escola de Frankfurt e da prestigiada New Left Review, trincheira de historiadores como Hobsbawn, Hill e Thompson (FALCON, 2007, p. 105). Também os Annales, apesar de seu papel de precursores no ataque à história política tradicional, deram, a partir de suas gerações mais recentes, sua contribuição para a renovação deste campo do conhecimento histórico. Abandonando a projeto de uma "história total", a nouvelle historie concluía que não havia mais a história, mas "múltiplas histórias". Assim, a terceira geração dos Annales foi buscar em autores de outros campos do saber - como Hannah

\footnotetext{
${ }^{12}$ Como "marxismo ocidental" referimo-nos às perspectivas que, referenciando-se criticamente no pensamento de Karl Marx e Friedrich Engels, não se vinculavam à história "oficial" produzida pelos historiadores associados à linha soviética. As abordagens estruturalistas, embora normalmente não sejam associadas a essa corrente "ocidental”, tampouco fazem parte da escolástica produzida com o nome de história da URSS.
} 
Arendt, Max Weber e Norbert Elias - inspiração para renovar o estudo do político, aproximando a história de novas concepções como poderes (ao invés de poder), saberes e práticas discursivas (Ibid., p. 107). As interações entre a História e outros campos das ciências sociais - notadamente a Antropologia e a Ciência Política - enriqueceram as possibilidades interpretativas dos historiadores e tiveram papel decisivo na renovação da história política, como nos permite perceber a influência do conceito de "Cultura Política", tomado da ciência política.

Além disso, preocupações metodológicas foram acrescentadas à discussão sobre o lugar do político na produção do conhecimento histórico, ampliando o escopo em torno de suas polêmicas para além do problema do poder. Desde os anos 1970 a retomada do interesse pelos estudos da história política vinha alimentando intensos debates, como lembra Barros (2009):

Em 1972, por exemplo, em um artigo que se propunha a traçar um panorama das
tendências da história política mais recente, Jacques Le Goff lançava uma instigante
pergunta, que terminou por dar título ao ensaio: "A política será ainda a ossatura da
História?" (LE GOFF, 1975). Já em 1974, em um texto menos panorâmico do que
polêmico, Jacques Julliard contribuía para o conjunto de ensaios da obra coletiva
Faire de l'Histoire com uma digressão sobre A Política que principiava com uma
afirmação sobre a má reputação da História Política entre os historiadores franceses,
acompanhada de uma descrição de seus principais vícios e pecados (JULLIARD,
1988, p. 180). Extremamente provocativo, este texto gerou uma resposta incisiva de
René Rémond sob a forma de uma dupla introdução que apresentava precisamente
uma obra coletiva de historiadores que se orgulhavam de se auto-qualificarem como
historiadores políticos e que trazia o sintomático título "Por uma História Política",
publicada logo depois. (BARROS, 2009, p. 2).

As contundentes críticas, dirigidas particularmente por Jacques Julliard à história política tradicional em seu célebre A Política (1988), também atingiram a nova história política. O historiador francês se perguntava então se a história política poderia superar a imposição do factual - e, portanto, do descritivo - em favor de uma abordagem que privilegiasse a longa duração (JULLIARD, 1998, p. 185). A ele, Rémond respondeu lembrando que a política também se inscreve na duração - e talvez até na longuíssima duração (RÉMOND, 1994, p. 19). As instituições, por exemplo, são duradouras mesmo quando os regimes se sucedem. Ademais, existiriam constantes que assegurariam as tradições do pensamento, configurações que são estáveis como, por exemplo, a separação entre direita e esquerda, além de outros hábitos e comportamentos, como heranças que evoluem lentamente, de geração em geração (Idem). 
Como destaca Barros (2009), um exemplo interessante neste sentido é a experiência de Annie Krigel ao trabalhar com o que ela mesma denominou como "etnografia política" do Partido Comunista Francês, como uma espécie de contra-sociedade, com suas próprias hierarquias, regras, rituais, códigos de linguagem, uma sociedade autônoma, enfim (KRIGEL, 1968 apud BARROS, 2009, p. 15). Interpretações como as de Krigel reapareceriam décadas depois nos estudos que utilizam o conceito de Cultura Política para a análise de objetos como partidos políticos, marcando um ponto de inflexão na aproximação entre a História e a Ciência Política.

\subsection{A ideia de "Cultura Política"}

No bojo do processo de renovação da história política e de sua aproximação com outras áreas das ciências sociais, o conceito de Cultura Política ${ }^{13}$ foi incorporado ao instrumental teórico-metodológico dos estudos históricos, sendo largamente utilizado em inúmeros trabalhos acadêmicos nos últimos anos, muitos deles dedicados ao estudo de partidos políticos, como o PCB. Por unir dimensões da Ciência Política, dos estudos culturais e da Antropologia, a proposta teve boa acolhida entre os historiadores mais vinculados à crítica dos "grandes objetos" da história política.

O conceito foi apresentado por Gabriel Almond e Sidney Verba nos anos 1960, na clássica obra The Civic Culture: political attitudes and democracy in five countries ${ }^{14}$. Em sua formulação original, a Cultura Política seria um conjunto de percepções, sentimentos e avaliações capazes de expressar o sistema político de uma sociedade. Para os cientistas políticos estadunidenses, o estudo da Cultura Política tinha como finalidade enaltecer a "cultura política democrática" como superior às demais. Para eles, a grande questão que se colocava então era entender as condições para o estabelecimento da democracia - entendida como o sistema político norte-americano, em contraposição ao soviético - e sua manutenção (CASTRO, 2008, p. 3). Isso porque, após a Segunda Guerra Mundial, os estudos da Ciência Política buscaram encontrar um equilíbrio entre estabilidade democrática e exercício da cidadania, compreendendo o funcionamento da democracia de massas. O enfoque elitista e realista - no qual as qualidades individuais de civilidade, tradição e tolerância das elites se

\footnotetext{
13 Para diferenciar o conceito de Cultura Política da referência nominal a uma ou mais culturas políticas específicas, utilizaremos o primeiro termo com letras maiúsculas e, o segundo, com letras minúsculas.

${ }^{14}$ ALMOND, G.; VERBA, S. The Civic Culture: political attitudes and democracy in five countries. Newburry Park: Sage, 1989. Numa livre tradução: A cultura cívica: atitudes políticas e democracia em cinco países.
} 
integram à apatia moderada das massas, vistas como salvaguardas da democracia - estava na base dos primeiros estudos da Cultura Política (RENÓ, 1998, p. 74).

Nos anos de 1980 e 1990 historiadores franceses, muitos deles engajados no processo de renovação da história política, questionaram os limites nacionais e etnocêntricos desta abordagem inicial. Para desvendar o fenômeno, os franceses defendiam a tese de que várias culturas políticas poderiam coabitar num mesmo espaço, questionando Almond e Verba sobre a possibilidade de distintas "civilizações" compartilharem de culturas políticas idênticas. Nas palavras de Berstein (2009):

\begin{abstract}
Os historiadores entendem por cultura política um grupo de representações, portadoras de normas e valores, que constituem a identidade das grandes famílias políticas e que vão muito além da noção reducionista de partido político. Pode-se concebê-la como uma visão global do mundo e sua evolução, do lugar que aí ocupa o homem e, também, da própria natureza dos problemas relativos ao poder, visão que é partilhada por um grupo importante da sociedade num dado país e num dado momento da sua história. Jean François Sirinelli (1992) propôs considerá-la "uma espécie de código e [...] um conjunto de referências, formalizados no seio de um partido ou mais largamente difundidos no seio de uma família ou de uma tradição política”. (BERSTEIN, 2009, p. 31).
\end{abstract}

Em outras palavras, uma cultura política ofereceria um repertório que dá àqueles que aderem a ela formas comuns de enxergarem o mundo, interpretando-o e atuando sobre ele. Os franceses aceitavam a ideia de que existe uma relação direta entre as atitudes e valores políticos dos cidadãos e o funcionamento dos sistemas políticos, em que a cultura seria uma forma de integração dessas dimensões. Mas discordavam de Almond e Verba na aplicação do conceito, pois não acreditavam na existência de culturas políticas nacionais homogêneas, destacando que várias culturas políticas poderiam conviver numa mesma sociedade, negandose e influenciando-se mutuamente. Aproximando-se da perspectiva francesa, Motta (1996) nos dá definição semelhante ao considerar a Cultura Política como um:

[...] conjunto de valores, tradições, práticas e representações políticas, que é partilhado por um grupo, sendo que esse conjunto acaba por expressar uma identidade coletiva e por fornecer leituras comuns do passado, bem como inspirar novos projetos para o futuro (MOTTA, 1996, p. 123).

Para Berstein, a base dessas culturas políticas seria um determinado "substrato filosófico" disseminado nas sociedades. Por exemplo, quando alguém defende que é natural que um operário se organize enquanto classe contra a opressão de seu patrão, está aderindo aos princípios marxistas da luta de classes; quando outro sustenta que qualquer presença do 
Estado na economia é uma afronta à liberdade, está expressando os valores do liberalismo. Esse substrato presente nas sociedades se expressa livremente e encontra referências históricas e símbolos que, junto com uma representação da sociedade atual e seus impasses, constituem uma cultura política (BERSTEIN, 2009, p. 34). Assim, a cultura política seria um fenômeno ao mesmo tempo plural (por isso a ideia de "culturas políticas"), evolutivo (isto é, inscrito historicamente nas transformações da sociedade), individual (profundamente enraizado nos valores de cada pessoa) e coletivo (formador de identidades grupais). (Ibid., p. $35)$.

Mas, apesar de largamente utilizado, o conceito de Cultura Política também tem sido alvo de inúmeros questionamentos. De determinadas vertentes marxianas surgiu a crítica de que a noção de Cultura Política desconsideraria a ação dos aparelhos ideológicos do sistema capitalista; de correntes do pensamento liberal veio a acusação de que a Cultura Política ignoraria a possibilidade de escolha racional dos indivíduos a partir da fórmula “custo/benefício" (RENÓ, 1998, p. 72).

Ronald H. Chilcote, estudioso do PCB, aponta que a ideia de Cultura Política sofreria de um latente reducionismo, ao mesmo tempo em que mantém um viés favorável ao modelo liberal-democrático, baixo valor explicativo e falta de autonomia (CHILCOTE, 1994, apud RENÓ, 1998, p. 76). Imersa em preconceitos ocidentais de modernidade, a Cultura Política tomaria os países capitalistas industrializados como mais propensos a alcançar uma cultura democrática “cívica”. Para Chilcote, as alternativas teóricas mais viáveis para uma visão radical da cultura e da socialização fazem parte da contribuição marxista: os dois principais eixos do debate são a socialização na formação da consciência de classe e a visão humanista do marxismo, que enfatizam a capacidade cultural humana de transformação da realidade e eliminação da alienação através da politização dos valores ${ }^{15}$.

Como Chilcote, consideramos que há importantes lacunas na proposta de Cultura Política, especialmente no que diz respeito à necessidade de definição quanto aos conteúdos das culturas políticas (que, a rigor, estão em permanente transformação), e à controversa separação entre cultura e estrutura política e as dúvidas sobre o caráter causal desta relação ${ }^{16}$. No caso do PCB dos anos 1940, por exemplo: que cultura política um partido recémreagrupado, saindo da clandestinidade e ingressando no sistema liberal-democrático expressaria? Há uma cultura política comunista "padrão" a partir da qual poderíamos classificar os partidos um a um? Ciro Flamarion Cardoso lembra que, para os historiadores da

\footnotetext{
${ }^{15}$ Cf. Ibid., p. 77.

${ }^{16}$ Cf. Ibid., p. 76.
} 
política na longa duração, o historiador que se propusesse escrever a história política como recriação de uma cultura política, deveria dar ênfase tanto naquilo que as pessoas pensavam que estavam fazendo e nas razões pelas quais o queriam fazer, quanto no resultado real (muitas vezes não pretendido) de suas ações.

Assim, para Cardoso, os historiadores da política deveriam se dedicar tanto às intenções e preocupações dos indivíduos, quanto aos eventos da política (2012, p. 44). Além disso, haveria uma enorme deficiência na proposta metodológica em Berstein, uma vez que:

[...] considera temas como "mentalidades", "representações" ou "imaginário" como algo antônimo à realidade. Se os "traumatismos" - notadamente fenômenos de natureza socioeconômica - sugeridos por Bernstein podem transformar ou mesmo extinguir uma cultura política, porque estes elementos foram suprimidos da análise historiográfica em favor das "representações"? (CARDOSO, 2012. p. 45).

Para Renó (1998), a perspectiva atual da Cultura Política (posterior aos anos 1990) é a de uma teoria "culturalista" da política, na qual as preferências são ensinadas e criadas. Assim, a cultura condiciona as escolhas e a ação política. A proposta da Cultura Política tenderia a repetir, segundo Mendonça e Fontes, a trágica separação que a história social manteve diante das dimensões do poder e da política por décadas (2012, p. 59).

Apesar de suas flagrantes limitações, não seria justo nem inteligente ignorar as contribuições que a proposta da Cultura Política aportou aos estudos históricos. Mesmo porque sempre que a dimensão cultural foi deixada de lado o que se viu foi a hipervalorização das estruturas e o menosprezo pelo poder das ideias. Dulce Pandolfi, como veremos à frente, deu importante contribuição aos estudos sobre o PCB ao utilizar a noção de "cultura política comunista" para reconstruir em forma de registro historiográfico a memória e identidade criadas pelo partido ao longo de sete décadas, identificando a centralidade que essas categorias têm para a manutenção de projetos partidários dessa natureza.

Outras propostas, alternativas à ideia de Cultura Política, também buscaram desvendar a relação entre política, cultura, dominação e identidade. Para Castro, a "teoria da hegemonia" de Antônio Gramsci seria uma concepção alternativa para o estudo da cultura política (2008, p.16). Segundo a teoria de Gramsci, os setores dominantes nas sociedades ocidentais não exercem sua dominação apenas pela coerção. A opressão das elites seria resultado da combinação entre força coercitiva e liderança moral. A essa combinação Gramsci dá o nome de hegemonia, um poderoso mecanismo através do qual as classes dominantes garantem e justificam sua dominação, constituindo um sistema de crenças e valores que são assimilados 
pelo conjunto da sociedade ${ }^{17}$. Assim, a hegemonia seria uma forma de dominação que se manifesta através do consentimento "espontâneo" das massas em relação à direção imposta pelos grupos dominantes. Para Gramsci, as classes - ou frações de classe - que exerciam seu domínio o faziam através de uma direção "político-cultural" (COUTINHO, 2007, p. 64). Vemos aqui a centralidade que a cultura tem na proposta de Gramsci e o papel que cumpre em sua forma de compreender a política e as relações de dominação.

Como se nota, a proposta de Cultura Política enriqueceu as possibilidades interpretativas dos historiadores políticos, não obstante os inúmeros questionamentos que o conceito suscitou nos círculos acadêmicos. Mas, ao se converter em paradigma "hegemônico" para o estudo de determinados objetos do "político", o conceito tornou-se um obstáculo a outras abordagens tão ou mais ricas que ele próprio. Daí a necessária retomada de outras perspectivas para o estudo do político na história.

\subsection{Perspectivas críticas sobre a história política}

Como vimos, a história política se renovou na segunda metade do século XX, graças ao esforço combinado de diferentes correntes da historiografia ocidental. As mudanças processadas no interior da tradição dos Annales (que trouxeram consigo um renovado interesse pela política), os embates no campo do pensamento marxiano (que culminaram com a derrocada do estruturalismo) e a crescente influência das ideias de Foucault (sobre o poder e as relações de dominação) levaram a uma retomada dos estudos históricos sobre a política em suas mais variadas dimensões.

Também vimos que o processo de "ressurgimento" da história política, embora tributário de diferentes ondas de renovação das tradições historiográficas, não se deu sem conflito. Apesar de terem em comum a negação da forma tradicional de fazer história política - uma história dedicada aos feitos das elites governantes - as diversas formas de abordagem do político guardam entre si importantes diferenças. As polêmicas envolvendo o uso da noção de Cultura Política são apenas a demonstração mais recente das divergências existentes no campo da história política hoje.

\footnotetext{
${ }^{17}$ Marx já havia chegado a uma conclusão semelhante, ao considerar que a dominação de uma classe sobre as outras faz com que só sejam consideradas válidas, verdadeiras e racionais, as ideias da classe dominante. $\mathrm{O}$ tema das fontes constituintes dos valores, ou seja, da relação entre as "relações materiais" e os valores, seguem sendo objeto de controvérsia ainda hoje, sobretudo após o estrago provocado pelo estruturalismo althusseriano. Gramsci, por sua vez, avança em relação a Marx, na medida em que explica o fenômeno, ao invés de limitar-se a detectá-lo.
} 
A enorme aceitação que a proposta culturalista encontrou entre os historiadores devese a um questionamento geral acerca da validade do estudo dos objetos tradicionais da história, como as civilizações, a economia, o Estado e os grandes processos de transformação, como as revoluções. Esse questionamento ampliou os horizontes da pesquisa histórica e enriqueceu as possibilidades de investigação. Mas obstruiu, por muito tempo, uma abordagem renovada desses mesmos objetos. Agora que o político ressurge com protagonismo e a capacidade explicativa dos estudos culturais revela suas limitações, outro embate se desenrola: o lugar da ação política nos novos estudos históricos.

De um lado, ignorando as dimensões institucionalizadas da política, ganhou força uma abordagem que privilegiava os discursos, as representações e o imaginário. Como sinônimo de poder, o político estaria "pulverizado" em toda parte. De outro lado, desconsiderando que a política tem seu lugar, a tentativa de localizar nas “determinações sociais do poder" todas as explicações para o que acontece no âmbito do político. Como destaca Falcon, ambas as abordagens são problemáticas:

\begin{abstract}
Em face das muitas tendências e das variações e ênfases ou preferências observáveis no bojo do movimento de renovação da história política, é conveniente fazer uma distinção entre as orientações mais moderadas e as mais radicais. Radicais, do nosso ponto de vista, são as interpretações que conduzem o historiador a subsumir a política na esfera do poder, de modo que se perde de vista quase por completo sua autonomia. Por outro lado, como muitas abordagens do poder remetem às suas determinações sociais, a tendência passa a ser substituir a história política por algum tipo de história das formas de dominação, não vindo ao caso se baseada na matriz teórica marxista, weberiana ou outra qualquer (1997, p.89).
\end{abstract}

Como, então, contornar as armadilhas presentes nessas interpretações e dar à política, ao poder e ao Estado, lugares adequados na produção de uma história política crítica? Será necessário aqui, superar os obstáculos epistemológicos expressos de maneira antagônica nas ideias de que "tudo é política" e de que "a política não existe" (Idem). A resposta, nos parece, está na teoria de Antônio Gramsci.

A grande descoberta de Marx e Engels no campo da teoria política foi a afirmação do caráter de classe de todo fenômeno estatal. Essa conclusão os levou, contrapondo-se a Hegel, a "desfetichizar" o Estado, já que este seria expressão das contradições presentes na sociedade como um todo (COUTINHO, 2007, p. 123). Como expressão da dominação de classe, sua manifestação se daria, sobretudo, na forma de um Estado coercitivo, cujo objetivo supremo seria o de manter inalterado o status quo. Num tempo em que a participação política encontrava limitações materiais, em que a ação das classes subalternas se dava em rompantes 
de fúria ou na forma de pequenos círculos conspiratórios, não é estranho que Marx e Engels tenham uma visão tão estreita do Estado $^{18}$.

Quando Gramsci desenvolve seus estudos, no final dos anos 1920, a política e o Estado, em especial na Europa Ocidental, haviam passado por profundas transformações. Numa de suas anotações, por exemplo, Gramsci destaca que "o conceito de organização em Marx permanece ainda preso aos seguintes elementos: organizações profissionais, clubes jacobinos, conspirações secretas de pequenos grupos, organização jornalística" (GRAMSCI, 1975 apud COUTINHO, 2007, p. 125). O espanto de Gramsci com a noção marxiana de organização se expressa num momento em que a política ganhava dimensões de massas, com grandes sindicatos operários e partidos que congregavam milhares de membros - como os partidos fascista e comunista, na Itália dos anos 1920.

Para Gramsci, o Estado em sentido amplo comporta duas esferas principais: a sociedade política (o Estado em sentido estrito) e a sociedade civil (na qual estão as organizações responsáveis pela elaboração/difusão das ideologias: o sistema escolar, as igrejas, os partidos políticos, os sindicatos e toda a organização material da cultura) ${ }^{19}$. Para ele, é a soma dessas duas dimensões (sociedade política + sociedade civil) que formam o Estado (GRAMSCI, 1975 apud COUTINHO, 2007, p. 125). Ambas servem para manter o domínio de classe, mas uma utiliza meios formais de coerção, e outra, uma refinada forma de dominação cultural, a hegemonia.

O conceito de Estado ampliado cria, assim, uma unidade orgânica entre duas dimensões mutuamente dependentes. Em Gramsci, o poder estatal, mesmo representando uma dominação de classe, não poderia realizar-se apenas por meios coercitivos: para ele, a própria construção das vontades torna-se o objeto de uma disputa política que se desenvolve na sociedade civil (MENDONÇA; FONTES, 2012, p. 63).

Gramsci pensa o Estado ampliado (sociedade civil + sociedade política) como um terreno de permanente interação. Desse modo, o poder não estaria nem "concentrado" no Estado, nem "disseminado" pela sociedade. Ele transitaria entre essas duas esferas numa relação dialética. A cultura, como componente da sociedade civil, cumpriria papel fundamental na conformação dessa realidade, conforme demonstram Mendonça e Fontes:

\footnotetext{
${ }^{18}$ É necessário lembrar, porém, que não há consenso entre os pesquisadores sobre as opiniões de Marx e Engels acerca do Estado. As polêmicas entre Lenin e Nikolai Bukharin às vésperas da Revolução Russa de 1917 são bastante ilustrativas da dificuldade que os marxistas tiveram em determinar uma interpretação "correta" da teoria do Estado em Marx. Para conhecer mais sobre as divergências entre Lenin e Bukharin cf. COHEN, S. Bukharin - uma biografia política. São Paulo: Paz e Terra, 1990.

${ }^{19}$ Para Gramsci: jornais, revistas, editoras, meios de comunicação de massas etc.
} 
Cultura, para Gramsci, compõe-se do conjunto dos projetos e visões de mundo pautado por valores, crenças e auto percepções de indivíduos e grupos sobre seu lugar social - desenvolvidos por cada classe ou fração em permanente disputa [...]. É a disputa pela afirmação da hegemonia de certa fração de classe - organizada em seus aparelhos privados de hegemonia - que institui não só a política, como o Estado ampliado, ambos indissociáveis da cultura. Logo, em Gramsci, cultura e política estão inseparáveis, mas não à maneira dos que pretendem reduzi-las ao espaço etéreo das ideias e representações sem vínculos com a base socioeconômica de onde emergem, tampouco como os que as analisam como um conjunto homogêneo, desprovido de conflitos e tensões, "apaziguados" por abordagens culturalistas (Idem).

Ao definir o lugar da política, do poder e da cultura, no contexto de permanentes e incontornáveis tensões de classe, Gramsci oferece-nos uma alternativa teórica às perspectivas reducionistas que perseguem o objetivo de produzir uma história "puramente" cultural ou política. No caso de um partido político, como o PCB, que expressa através dos ritos, memórias, linguagem, e mesmo da estética, uma determinada cultura política, temos um manancial inesgotável para a pesquisa histórica, de acordo com as abordagens gramscianas.

Nosso objeto de pesquisa - um partido político comunista - encontra-se nessa intersecção. Como aparelho difusor de cultura, o PCB compunha a sociedade civil, expressando e disputando determinadas visões de mundo. Mas quando ascende à Assembleia Constituinte, em 1946, passa a compor a sociedade política (o Estado), e vive as contradições de transitar entre essas duas esferas. Como vemos, a partir dessa abordagem, as possibilidades teóricas para o estudo dos partidos políticos tornam-se variadas, cabendo-nos aprofundá-las antes de dar início ao estudo do PCB em si.

\subsection{História e partidos políticos}

Retomando Gramsci, consideramos que uma história dos partidos políticos só pode ser feita numa perspectiva panorâmica, isto é, levando-se em conta que esses organismos são grupos sociais que "não estão isolados: têm amigos, afins, adversários, inimigos" e que "só do quadro complexo de todo o conjunto social e estatal (e frequentemente com interferências internacionais) resultará a história de um determinado partido" (GRAMSCI, 1976, p. 24.).

No entanto, como vimos, há diferentes propostas teórico-metodológicas para o estudo dos partidos políticos e é necessário debruçar-se sobre elas antes de aderir a uma teoria. A mais conhecida - e a que por mais tempo influenciou os estudos acerca dos partidos políticos - é aquela apresentada por Maurice Duverger na obra Os Partidos Políticos, publicada pela primeira vez em 1951. Antes dele, porém, outros pensadores já haviam se dedicado a refletir sobre os sistemas políticos e os partidos. Já no século XVIII, filósofos como David Hume 
(1742) e Edmund Burke (1770) discutiam os aspectos positivos e negativos da atuação partidária diante dos interesses gerais da sociedade (PERES, 2009, p. 4). Por que então Duverger provocou um impacto tão profundo e duradouro sobre os estudos acerca dos partidos políticos? Basicamente, porque ele foi o primeiro a propor a um modelo teórico e metodológico completo de análise organizacional dos partidos políticos: uma "teoria geral dos partidos".

Assim como na história política tradicional, os estudos acerca dos sistemas políticos no fim do século XIX eram extremamente formalistas, concentrando suas atenções nas instituições, leis e governos. Na virada do século, porém, surgiram novas abordagens que propunham analisar as "forças vivas" que moveriam a política na nascente democracia de massas: os partidos políticos (Ibid., p. 5). Nesse contexto surgiram os primeiros estudos de sociólogos como Ostrogorski (1903) e Michels (1911), pioneiros na utilização de metodologias científicas para o estudo dos partidos políticos. Inspirados neles e noutros pensadores $^{20}$, Duverger desenvolveria um estudo panorâmico sobre a genealogia dos partidos políticos modernos, sua composição, funcionamento, dentre outras características componentes de uma teoria geral dos partidos.

No processo de estudo dos partidos políticos, Duverger identificou dois grandes grupos nos quais os partidos políticos modernos poderiam ser classificados. O primeiro seria formado pelos "partidos de quadros", e o segundo, pelos "partidos de massas". Os primeiros, mais antigos, teriam surgido na origem da democracia representativa, formados por grupos aristocráticos que já ocupavam os espaços de representação parlamentar, desvinculados, portanto, de demandas sociais ou corporativas. Os "partidos de massas", por sua vez, teriam sua origem em grupos sociais organizados que decidiram lutar pelo poder através da representação parlamentar, como os sindicatos, por exemplo, criando estruturas políticas de "baixo para cima".

A origem de cada um desses tipos partidários traria consigo determinadas características que permitiriam uma classificação geral dos partidos num destes grupos. Os partidos de quadros (mais burgueses e aristocráticos) se caracterizariam por pouca atividade de recrutamento (ação preponderantemente eleitoral), financiamento autônomo através das próprias elites partidárias, pouca complexidade administrativa, direção personalista, pouca consistência programática e ideológica. Já os partidos de massas, encarnariam exatamente o

\footnotetext{
${ }^{20}$ Peres (2009) destaca que antes de Duverger, Max Weber já havia antecipado, num texto chamado Gesammelte Politische Schriften, a distinção entre "partidos de notáveis" e "partidos de massa", distinção explorada e aprofundada por Duverger em 1951.
} 
oposto: dedicação permanente ao recrutamento de novos membros, atividades constantes de doutrinação e propaganda, financiamento militante, complexidade na organização e existência de uma burocracia dirigente, disputas orientadas por divergências programáticas, estrutura decisória fortemente hierárquica e baixo personalismo das lideranças (PERES, 2009, p. 16). A partir desta divisão, Duverger estudará as características de cada um desses grupos, abordando o grau de centralização, de relevância das regras internas, a política de financiamento, de filiação, o caráter dos objetivos, a dinâmica dos processos decisórios, a disciplina partidária, dentre outros temas.

Como fica evidente, Duverger identifica os partidos de quadros, formados de cima para baixo, a partir dos grupos parlamentares, sem a adesão de setores sociais organizados, aos velhos partidos oligárquicos - liberais ou conservadores - presentes em todas as democracias existentes no início do século XX. Ao mesmo tempo, identifica os partidos de massas com os partidos socialistas e comunistas, normalmente de origem proletária e mais ideológicos que as velhas máquinas partidárias. Essa associação nos parece correta, sobretudo no que diz respeito às origens e características gerais dos partidos "de quadros" e "de massas". Porém, as muitas transformações vividas pelo mundo desde o lançamento de $O s$ Partidos Políticos defasaram parte daquela abordagem, exigindo críticas e atualizações.

As teses de Duverger partem do mesmo "elitismo" de seus antecessores, que acreditavam que democracia seria sinônimo de oligarquia. Para ele, a democracia seria apenas um espaço mais adequado para o recrutamento de uma "elite política" que exerceria funções de mando na estrutura do Estado. Nas palavras do próprio Duverger:

\footnotetext{
A significação mais profunda dos partidos políticos é que eles promovem a criação de novas elites, que restituem o verdadeiro sentido da representação, o único sentido real. Todo governo é oligárquico por natureza: mas a origem das oligarquias e sua formação podem ser muito diferentes, e é isso o que determina sua ação. É preciso substituir a fórmula governo do povo para o povo pela seguinte: governo do povo por uma elite oriunda do povo (DUVERGER, 1987).
}

Para Duverger, a superioridade dos partidos de massas consistiria precisamente no fato de estes estarem mais aptos a "recrutarem" uma elite política mais vinculada aos interesses populares que os "partidos de quadros", estando assim em melhores condições de realizar o sentido fundamental da democracia representativa.

A tese de Duverger, além de elitista, sofre ainda outras limitações. Baseada essencialmente na experiência parlamentarista europeia, sua aplicação a outras realidades é frágil. Ademais, mesmo em se tratando dos sistemas políticos da Europa, o modelo ignora 
transformações decisivas como o crescimento de antigos "partidos de quadros" e o definhamento de típicos "partidos de massas". Da mesma forma, desconsidera composições "híbridas" que reúnem características de ambas as classificações e ignora a possibilidade de formações políticas que não se referenciem a partir, exclusivamente, da sua relação com o parlamento. Assim, apesar de oferecer uma alternativa metodológica inovadora e de "historicizar" o fenômeno dos partidos políticos, parece-nos que a fórmula dicotômica entre partidos de "quadros" ou de "massas" é demasiado limitada ${ }^{21}$.

Outra abordagem nos é oferecida por Angelo Panebianco, que se dedica menos à classificação dos partidos e mais à sua dinâmica interna. Ele considera que o estudo acerca dos partidos políticos se inscreve mais amplamente no que ele denomina "estudos organizacionais" e deve servir-se de teorias disponíveis neste campo para explicar a dinâmica das organizações partidárias.

Ao contrário de outros estudiosos das organizações partidárias, Panebianco considera impossível analisar as atividades dos partidos, seja a partir de sua formação social, seja a partir dos objetivos por ele proclamados. De acordo com ele, a ideia de "partido operário" ou "partido burguês" não faria sentido, já que o próprio partido seria um sistema autônomo de desigualdades - que, apesar do epíteto "autônomo", guarda relação com as desigualdades sociais externas ao partido - sendo impossível compreendê-lo considerando exclusivamente a análise social de seus quadros.

Dessa forma, o fato de um partido ter mais operários ou indivíduos oriundos das elites econômicas, pouco diz a respeito de sua dinâmica de funcionamento. Por outro lado, Panebianco também considera um erro analisar um partido segundo os objetivos proclamados através de sua ideologia. Seria mais correto, para ele, aceitar que "os partidos perseguem políticas para ganhar eleições mais do que tentam vencer eleições para perseguir políticas"

\footnotetext{
${ }^{21}$ Exemplo disso deu-se no início dos anos 1980 nas discussões sobre o perfil do Partido dos Trabalhadores (PT). Composto por diferentes correntes da esquerda brasileira, o PT uniu diferentes propostas organizacionais com o objetivo de construir um perfil de funcionamento condizente com os objetivos de construção de um socialismo democrático. Nesse contexto, duas alas se opuseram fortemente: de um lado, as organizações políticas oriundas da luta clandestina contra a Ditadura Militar, com seu padrão militar de organização, inspirado na experiência bolchevique. De outro, setores sociais ligados ao novo sindicalismo operário da Grande São Paulo, às comunidades eclesiais de base e intelectuais moderados, advogavam a ideia de um partido amplo, distante da experiência dos partidos comunistas, ademais identificada com o autoritarismo da experiência stalinista. Os primeiros defendiam a ideia de um "partido de quadros", isto é, altamente hierarquizado, com um comando e instâncias firmemente organizados e com padrões mais rígidos de filiação; os segundos, defendendo um "partido de massas", imaginavam um grande partido de corte popular, composto por trabalhadores assalariados de baixa instrução, profissionais liberais, lideranças populares e por todos aqueles que se identificassem com a vaga ideia de um "governo dos trabalhadores". Esse debate arrastou-se durante os primeiros fóruns nacionais do jovem partido, até que foi superado pela engenhosa fórmula "partido de massas e de quadros", demonstrando que a terminologia de Duverger já não encontrava eco sequer quando apropriada diretamente pelos atores envolvidos na construção de um novo partido político.
} 
(PANEBIANCO, 2005, p. 8). O autor reconhece, porém, que a tese de que os partidos existem unicamente para alcançar vitórias eleitorais não explica o fato de alguns partidos adotarem políticas que, deliberadamente, dificultam sua vitória ou crescimento eleitoral.

Para Panebianco, o debate teórico sobre a organização dos partidos políticos encontrase diante de quatro dilemas interpretativos. O primeiro opõe a proposta racional e a proposta natural. $\mathrm{Na}$ proposta racional, as organizações existem para a realização de objetivos específicos, à luz dos quais se pode compreender toda a natureza das mesmas. Na proposta natural, o único objeto em comum é a própria manutenção da organização, através da qual cada membro busca viabilizar seus próprios objetivos individuais. Em alguns casos, esse “dilema" é apresentado na forma de transição da proposta racional (quando a organização se forma em torno de objetivos coletivos) para a proposta natural (quando o que mantém a organização é a busca por ganhos individuais). A essa transição, Michels chamou "teoria da substituição dos fins".

O segundo dilema consiste na relação entre incentivos "coletivos" e incentivos "seletivos". Para Panebianco, os partidos - e organizações em geral - só podem existir mediante o oferecimento de "incentivos organizativos", por meio dos quais os integrantes do partido manteriam seu vínculo com a organização. Nessa visão utilitarista, os incentivos coletivos seriam de natureza ideológica ou de solidariedade, o que manteria o tecido da organização unido. Os incentivos seletivos, por sua vez, seriam incentivos de poder, status e ganhos materiais (Ibid., p. 18). Segundo Panebianco, os dois tipos de incentivo estão em contradição permanente, mas são ambos indispensáveis à sobrevivência da organização: sem incentivos coletivos, o partido perderia vigor militante, enquanto a falta de incentivos seletivos levaria a um desinteresse pelo cumprimento de tarefas de direção:

\footnotetext{
Esse raciocínio explica por que os objetivos oficiais prescritos pela ideologia organizativa não são uma mera fachada; por que pelo menos algumas atividades limitadas no sentido de seu cumprimento devem ser realizadas; por que, finalmente, a atividade em franco contraste com os fins oficiais pode resultar, geralmente, em custos intoleráveis para a organização (Ibid., p. 21).
}

Um terceiro dilema apontado por Panebianco diz respeito à liberdade de ação dos dirigentes partidários diante das chamadas "coerções organizativas", isto é, os limites que a dinâmica da própria organização impõe a seus chefes. Para uns, a liberdade dos líderes partidários é enorme, já que eles controlam as instâncias partidárias e sua legalidade, as finanças, as políticas de recrutamento de novos militantes etc. Para outros, as ações das 
direções estão diretamente ligadas às negociações internas, muitas vezes fragilmente construídas, o que reduziria o espaço de manobra dos líderes em favor da estabilidade interna.

Por fim, um quarto dilema trata da "adaptação ao ambiente" versus o "predomínio" do partido nos ambientes em que se disputa com outras organizações partidárias. No primeiro caso estão aqueles partidos que se limitam à disputa de pequenos "nichos" eleitorais, adaptando-se à situação de predomínio de outros partidos. Ao contrário, as organizações que buscam predominar política e eleitoralmente seriam movidas por uma posição muito mais agressiva, pleiteando lugar de liderança dos sistemas políticos nos quais estão inseridas.

Como vemos, Panebianco apresenta uma série de questões adicionais àquelas inicialmente apresentadas por Duverger. Referenciando-se nas teorias de Michels e Pizzorno sobre os partidos, Panebianco propõem um esquema no qual o desenvolvimento das organizações partidárias poderia ser visto em três etapas fundamentais: a) gênese, b) institucionalização, c) maturidade. Mais uma vez, vemos uma proposta teórica alheia aos processos históricos e às dinâmicas nacionais.

Uma terceira perspectiva teórica (além das abordagens de Duverger e Panebianco) nos é oferecida por Berstein (1996). O autor, referência da nova história política, defende que há quatro critérios que permitem definir os partidos enquanto objeto específico de estudo. $\mathrm{O}$ primeiro seria o critério da duração no tempo, que garante ao partido uma existência mais longa que a vida de seus fundadores, permitindo que ele responda a uma tendência da opinião pública. O segundo, seria o da extensão no espaço, o que supõe uma organização nacional com estruturas locais. O terceiro, seria o da já conhecida "aspiração ao exercício do poder", exaustivamente discutido neste capítulo. E o quarto, por fim, seria o da vontade de contar com o apoio da população, seja recrutando militantes, seja atraindo votos (BERSTEIN,1996, p. 62). Como vemos, Bernstein se afasta pouco dos cientistas políticos estadunidenses em sua intenção de classificar as características que definem um partido político. De acordo com a abordagem sugerida por ele, partidos que tiveram poucos anos de vida, ou que não têm na "busca por votos" uma das suas razões de existir, ou ainda, que tenham uma inscrição regional ou local, não teriam relevância para a pesquisa histórica.

Além disso, para Berstein é papel dos historiadores "perceber a distância fundamental para a compreensão dos fenômenos históricos, entre a realidade e o discurso" já que "entre um programa político e as circunstâncias que o originam há sempre uma distância considerável, porque passamos então do domínio do concreto para o do discurso" (Ibid. p. 61), Como se nota, também para Berstein, a política e sua linguagem estão fora do mundo do concreto. 
Evidentemente, essa perspectiva, embora limitada, traz elementos importantes para a renovação do estudo dos partidos políticos. O mesmo Berstein, que considera o político como pertencente "à esfera do discurso e das representações especulativas" (Ibid. p. 60), adicionou contribuições relevantes às pesquisas sobre partidos ao destacar a importância do estudo do poder e da formação ideológica das organizações partidárias, avançando consideravelmente nas limitadas proposições dos cientistas políticos.

A pergunta que se coloca aqui é se alguma dessas teorias seria capaz de compreender a especificidade de um partido como o PCB, sua dinâmica interna, o peso dos ritos e tradições comunistas, as pressões da relação com os setores sociais por ele representados, dentre outros fatores indispensáveis ao desenvolvimento de nossa pesquisa acerca da presença dos comunistas na Assembleia Constituinte de 1946.

\subsection{A especificidade histórica dos partidos comunistas}

As abordagens sugeridas por Duverger, Panebianco e Berstein podem ser utilizadas para estudar qualquer partido. Algumas delas - como é o caso da proposta duvergeriana admitem que haja, nos partidos comunistas, uma especificidade tal que os torna diferentes dos demais. Para ele, os partidos comunistas fariam parte dos "partidos totalitários", e por essa razão, suas ações, funcionamento, estrutura e ideologia teriam características próprias. A proposta comunista, por exemplo, assumiria no esquema de Duverger um papel central, já que ela seria a forma pela qual o partido manteria o controle total da vida de seus membros (PANDOLFI, 1995, p. 45). A origem dos partidos comunistas também seria diferente dos demais cuja gênese foram os grupos parlamentares. Além de ter origem nos sindicatos, os comunistas teriam uma forma organizativa muito mais centralizada e coesa, e seus partidos teriam uma "eficiência organizacional" maior que a de seus concorrentes não comunistas (Idem). Outra abordagem que também classifica os partidos comunistas como "totalitários" é aquela oferecida por Neuman (1965), segundo a qual, "visando a constituições de governos monolíticos e negando a seus filiados qualquer possibilidade de escolha, esse tipo de partido exigiria uma submissão absoluta" (Ibid., p. 46). Como vemos, persiste entre muitos autores percepções formais acerca da natureza dos partidos comunistas - "centralizados", "totalitários", “disciplinados" etc. - que, além de reproduzir visões superficiais e preconceituosas, deixam escapar aquilo que os diferencia realmente dos demais partidos políticos: seu sentido de missão. 
Umberto Cerroni, filósofo italiano, sugere uma abordagem alternativa para definir a especificidade dos partidos comunistas. No artigo Para uma Teoria do Partido Político, Cerroni apresenta um histórico da difusão dos partidos políticos, a relação destes com as transformações vividas pelas instituições estatais e apresenta as dimensões que formam o partido político moderno: a de "partido-programa" e a de "partido-máquina". No mesmo estudo, Cerroni desenvolve uma vasta análise sobre o espaço reservado, no que ele chama de "sociedade de massas" aos partidos comunistas, apontando as possibilidades para a conquista do poder e a transformação da sociedade sem a necessidade do uso da força. (CERRONI, 1982 apud ROSA, 1996, p. 65). Neste estudo, Cerroni inclui um elemento distinto dos demais: a natureza política dos partidos comunistas - isto é, organizações que têm como finalidade proclamada a derrubada da ordem na qual estão inseridos - é o que faz de sua estrutura organizativa algo absolutamente singular, e não o inverso. Por isso, Cerroni conclui que ser um partido de "quadros" ou de "massas" não é uma opção que possa ser feita a priori, a partir de classificações arbitrárias, mas é resultado da inserção da organização, de sua leitura acerca de uma realidade sócio-política específica e de suas opções (Ibid. p. 67).

Outro pensador italiano, Lucio Magri, aprofunda a abordagem de Gramsci e Cerroni num artigo intitulado Problemas da teoria marxista do partido revolucionário. Nele, o partido é visto como uma força de vanguarda que busca a hegemonia diante de uma vasta e complexa formação de forças sociais, políticas e ideológicas. Magri rejeita a visão do partido que surge como "dono da verdade revolucionária" tal como consagrado pela tradição leninista do partido político: para ele, o partido é o instrumento de elaboração de uma verdade que é resultado da crítica constante às condições materiais existentes (MAGRI, 1977, p. 53). De acordo com ele, no "capitalismo maduro", o partido comunista surge como corpo orgânico, como transcendência da individualidade para a superação da oposição entre indivíduo e sociedade. Assim, o partido não exigiria a suspensão da liberdade individual de seus membros; ao contrário, a integração de suas crenças na forma de uma vontade geral constitui um passo necessário e imprescindível para a verdadeira fundação da liberdade, que se alcança na negação dos parâmetros impostos pela sociedade do consumo e da alienação (Ibid., p. 60).

Numa perspectiva oposta, Daniel Aarão Reis Filho sugere que os partidos comunistas sejam estudados como “organizações de estado-maior”. Segundo ele, essas organizações, por sua natureza, estruturam a coesão de seus membros com base em postulados e mecanismos de funcionamento que nem sempre estão subordinados às contingências da realidade imediata 
(como as eleições, por exemplo). Para ele, a herança marxista-leninista ${ }^{22}$ é o que determina a natureza das organizações de estado-maior. Essa herança diz respeito: a) ao processo da revolução socialista; b) ao papel do proletariado nessa revolução; c) ao papel do partido de vanguarda e aos mecanismos de coesão necessários à manutenção destes elementos como “mitos fundadores” (REIS FILHO, 1989, p. 107).

A obra de Marx tem inúmeras referências ao caráter histórico - e, portanto, finito - do capitalismo. Para ele, a existência de uma classe como o proletariado, com enorme potencial revolucionário, colocava em xeque a continuidade do sistema de exploração capitalista. Engrossava o otimismo de Marx o fato de o capitalismo ter contradições endógenas que se revelavam na forma de crises econômicas, guerras e concorrência desenfreada, o que ampliaria a exploração dos trabalhadores e sua necessidade de auto-organização na forma de um partido de classe. Sua crença de que o capitalismo poderia ser substituído por outra forma de organização social, porém, não se devia a uma "profissão de fé", mas a uma análise profunda que combinava o estudo do desenvolvimento histórico do capitalismo a uma filosofia da história que rompeu com a tradição do idealismo alemão. Por isso a proposta comunista surgiu reconhecendo a necessidade de partir das "condições objetivas" do desenvolvimento das forças materiais para desenvolver sua atuação política.

No entanto, no decorrer da história dos partidos comunistas, o que vimos foi a transformação da ideia de superação do capitalismo ora numa "promessa", horizonte inalcançável que ilumina a caminhada, ora num fenômeno inevitável, apocalíptico. Para o marxismo vulgar, desenvolvido pelos partidos comunistas ao longo da primeira metade do século XX, a revolução seria inerente ao processo histórico. Ela seria um destino, uma lei natural, cuja realização prescindia da vontade dos homens, não porque dispensáveis, mas porque determinadas historicamente pelas contradições do próprio capitalismo, já que a ação das massas a favor da revolução é um subproduto de seu próprio desenvolvimento (REIS FILHO, 1989, p. 108).

Sendo a revolução a promessa final da empreitada comunista, ela deveria ser acelerada por aquela classe que, como vaticinou Marx, está em antagonismo completo com a dinâmica do capital: o proletariado. Mas os proletários, dispersos e ocupados com sua sobrevivência, não poderiam desenvolver a consciência de sua condição de exploração senão através da organização política. Aqui entra o papel central do partido da classe, ilustrado no Manifesto

\footnotetext{
${ }^{22}$ A rigor, só podemos falar de Partidos Comunistas a partir da lógica do "marxismo-leninismo", termo consolidado ao longo da década de 1920 como sinônimo de "bolchevização" dos partidos afiliados à III Internacional Comunista, dirigida pelo Partido Comunista da União Soviética (PCUS). Até 1918 os bolcheviques usaram a denominação original do partido: Partido Operário Social Democrata Russo.
} 
Comunista como aquele que "teoricamente tem sobre o resto do proletariado a vantagem de uma compreensão nítida das condições, da marcha e dos fins gerais do movimento proletário" (MARX, 2012, p. 12). O partido seria indispensável porque, como forma suprema de organização política, exprimiria a vontade de libertação, consciente ou não, de toda a classe trabalhadora. E como exército em guerra contra a burguesia, o proletariado precisaria de um comando, representado pelo partido da classe e seus revolucionários profissionais, uma organização de elite (REIS FILHO, 1989, p. 114-136).

Combinando esses três elementos - inevitabilidade histórica da revolução, missão revolucionária do proletariado e imprescindibilidade do partido de vanguarda - temos, segundo Reis Filho, os postulados que conferem a razão de existir dos partidos comunistas e têm importância chave em sua estruturação enquanto organizações de estado-maior. Como destaca Reis Filho:

\footnotetext{
Na própria concepção de organização há, portanto, um duplo sentido excludente e antidemocrático: a vitória das lutas sociais, articuladas em termos de interesses imediatos das pessoas comuns, depende de uma teoria e de um Partido que não são e nem podem ser - patrimônio dos movimentos sociais. Estes são incapazes, por sua própria natureza, de atingir e dominar a teoria e de se organizar como Partido (REIS FILHO, 1989, p. 136).
}

Embora um pouco exagerada - já que os partidos comunistas, como quaisquer outros partidos, sempre buscaram atrair indivíduos para suas fileiras ao invés de obstruir o ingresso de novos elementos, como dá a entender a afirmação de Reis Filho - a percepção sobre o caráter excepcional dos partidos comunistas como organizações de estado-maior pode ser realçada pela equidistância que manteve separados os comunistas "leninistas" dos setores não organizados das massas.

Outras abordagens teóricas buscaram abordar o tema da relação entre o partido de "vanguarda" e os trabalhadores em geral, desde Leon Trotsky até Rosa Luxemburgo e György Lukács. No entanto, a que abordou de forma mais completa o problema do partido comunista no sistema político das democracias de massas, embora inscrita rigorosamente nos marcos do leninismo, foi a obra de Gramsci. Buscando enfrentar questões até então negligenciadas, ele sugere uma superação teórica à tese da "inevitabilidade da cisão entre os interesses do núcleo dirigente partidário e os interesses de sua referência social" (DEL ROIO; NERES, 2013, p. 141).

Gramsci desenvolve suas concepções sobre o partido a partir das polêmicas envolvendo as posições de Amadeo Bordiga, antigo dirigente comunista, que questionava o processo de "bolchevização" das frações marxistas do movimento operário italiano. Gramsci, 
que considera as posições de Bordiga "esquerdistas",23, desenvolverá uma séria de conclusões críticas que buscam "atualizar" política e organizativamente o Partido Comunista Italiano PCI.

Gramsci contesta a ideia de que o partido possa "dirigir a classe através de uma imposição autoritária vinda de fora", reivindicando formalmente a condição de "órgão revolucionário desta classe" (GRAMSCI, 2004 apud DEL ROIO; NERES, 2013, p. 147). O partido só pode conquistar a legitimidade de dirigir a classe operária na medida em que ele esteja vinculado à sua dinâmica real, fazendo com que os trabalhadores, assim, reconheçam o partido como seu. Gramsci pensa os partidos como elementos integrantes da sociedade civil, isto é, atores que compõem o conjunto de organizações que disputam suas concepções, valores e posições no interior das sociedades. Sua teoria da hegemonia teve impacto direto sobre sua formulação acerca do partido, inicialmente um mero apêndice da teoria leniniana ${ }^{24}$. Assim, Gramsci não compreende o partido comunista como portador de qualquer legitimidade natural para colocar-se como partido dirigente dos interesses da classe trabalhadora, mas como mais um partido que, na arena da sociedade civil, disputaria essa condição.

Anos mais tarde, já preso pelo regime fascista, Gramsci aprofundará seus estudos sobre a organização partidária. Concluirá que o partido comunista equivaleria ao moderno príncipe, numa alusão à obra de Maquiavel, e seria o único capaz de superar os resíduos corporativistas - os momentos "egoístico-passionais" da classe operária - e contribuir para a formação de uma vontade coletiva nacional-popular, ou seja, de um grau de consciência capaz de permitir uma iniciativa política que englobe a totalidade dos extratos de um país, transformando os interesses populares em interesses nacionais (COUTINHO, 2007, p. 169). Nos Cadernos do Cárcere, conjunto de anotações que desenvolveu ao longo de seus anos de prisão, o pensador italiano dialoga não apenas com seus adversários à esquerda, mas questiona as teses de Michels sobre a "lei de bronze da oligarquia", que apresenta a tendência à burocratização e oligarquização como inexoráveis aos partidos operários ${ }^{25}$.

\footnotetext{
${ }^{23}$ O próprio Lenin questionará as posições de Bordiga, em especial, sua defesa do abstencionismo eleitoral. Para aprofundar no conceito de "esquerdismo" cf. LENIN, V. Esquerdismo, doença infantil do comunismo. São Paulo: Editora Global, 1981. Para a atualidade do conceito de esquerdismo hoje cf. MEDEIROS, J. A atualidade de Esquerdismo, doença infantil do comunismo. In: Um mundo a ganhar - e outros ensaios. Rio de Janeiro: Editora Multifoco, 2012.

${ }^{24}$ Como teoria "leniniana" refiro-me à obra de Vladimir Ilicht "Lenin". As demais referências ao termo "leninista" referem-se à concepção de partido e à teoria organizativa implementada pelos partidos comunistas a partir da "bolchevização" do movimento comunista internacional disseminada por seus organismos internacionais, sob influência do Partido Comunista da URSS, após a morte de Lenin (1924).

${ }^{25}$ Como vimos, um dos pensadores que influenciaram toda uma geração de pensadores da política - incluindo Maurice Duverger - foi Robert Michels. Suas teses elitistas consideravam que a democracia seria plenamente impossível, já que os sistemas representativos sempre levariam à formação de uma oligarquia. Além disso,
} 
Para responder a este tema, Gramsci questiona precisamente a questão da democracia no interior dos partidos operários. Ele considera que a ruptura entre os interesses das cúpulas dirigentes e as bases é um problema real, que se resolve a partir do funcionamento das organizações. Para isso, estabelece uma contraposição entre "centralismo democrático" e "centralismo burocrático"26. Na interpretação de Del Roio e Neres:

\begin{abstract}
O primeiro tipo de centralismo, o único efetivamente capaz de criar uma articulação orgânica entre as forças econômicas e políticas que precisam ser organizadas, apresenta características de um "centralismo em movimento", de "uma contínua adequação da organização ao movimento real", combinando "os impulsos oriundos de baixo com o comando pelo alto", permitindo assim, "uma contínua inserção dos elementos que brotam do mais fundo da massa na sólida moldura do aparelho de direção" e assegurando a "acumulação regular das experiências" (GRAMSCI, 2001 apud DEL ROIO; NERES, 2013, p. 153).
\end{abstract}

Já o centralismo burocrático, estaria alheio à dinâmica viva do movimento histórico, seria incapaz de compreender as necessidades das massas e serviria tão somente como mecanismo perpetrador da liderança de uns sobre os outros. Com essa diferenciação, Gramsci não nega, portanto, que a burocratização seja uma tendência que pode afetar os partidos operários, mas contesta o determinismo da "lei" de Michels, uma vez que a forma com que cada partido se relaciona com sua própria democracia definiria outras possibilidades que não a oligarquização.

Para Gramsci, o funcionamento democrático do partido favorece a disciplina, não como uma imposição extrínseca, determinada por uma cúpula burocrática, mas como uma exemplificação concreta de liberdade, que "ao invés de anular a personalidade do militante", apenas impõe limites àquelas atitudes que poderiam comprometer o conjunto da coletividade (DEL ROIO; NERES, 2013, p. 154).

Portanto, a eficiência política da organização partidária decorre essencialmente da manutenção de mecanismos de funcionamento democráticos e da preservação de vínculos orgânicos com as massas proletárias. Como notamos, as formulações de Gramsci acerca da

considerava que a burocratização dos partidos operários era inevitável, devido à contradição entre "os interesses de reprodução da organização partidária e os interesses próprios de sua referência social". Para mais detalhes sobre a "lei de bronze da oligarquia" cf. MICHELS, R. Sociologia dos partidos políticos. Brasília: Editora da UnB, 1981.

${ }^{26}$ Apresentado por Lenin no Congresso do Partido Operário Social Democrata Russo, em 1902, o conceito de "centralismo democrático" compreende uma dinâmica de funcionamento amplamente democrática, onde as questões são debatidas exaustivamente antes de deliberação no interior das instâncias. Uma vez decidida (pelo voto ou através do consenso) seria dever de todos os militantes da organização, de forma disciplinada fazer cumprir de forma centralizadas as decisões da maioria sem questionamentos. Para saber mais sobre o conceito de centralismo democrático cf. LENIN, V. Que fazer? - Problemas candentes do nosso movimento. São Paulo: Expressão Popular, 2013. 
organização comunista, inscritas na tradição leninista, são tipicamente de "estado-maior". No entanto, as posições de Gramsci questionam a ideia de que estas organizações seriam necessariamente antidemocráticas.

Neste sentido, encontramos nas posições de Cerroni uma boa síntese entre as formulações de Gramsci sobre o partido e as de alguns dos pensadores clássicos que o sucederam, pois engloba tanto a visão liberal da associação de homens em função de determinados princípios ou interesses comuns, como a versão organizacionista (Duverger, Stálin, Michels), que vê na organização burocrática seu correspondente moderno (BRANDÃO, 1997, p. 24.). Nas palavras do autor:

Si con la expresión partido-programa designamos el planteo ideal de partido, y con el término partido-aparato o partido-máquina la formación técnico-institucional, podemos decir que la teoria del partido político tiende a extraer la segunda noción de su conexión orgánica con la primera a fin de estudiar las tendências y, si se quiere, las leyes de formación, funcionamiento y desarrollo del partido político, así como los instrumentos con los cuales los partidos luchan por el poder (CERRONI, 1977, p. 11).

Cerroni, no entanto, chama a atenção para o risco dessa operação de separação entre o político e o organizacional. Para ele, é preciso estar atento para o risco de desarticular a noção mesma de política moderna, perdendo de vista sua dupla natureza, a que Gramsci definia como "bestial e humana", baseada tanto na força do consenso quanto da autoridade, do individual e do universal. Nessa perspectiva, condena as abordagens "tradicionais" no estudo dos partidos políticos (representadas por Michels, Weber e Duverger), que tratariam a política como uma "ciência autônoma" (Ibid. p. 12). Para Cerroni - tal como para Gramsci - o partido político é um ente organicamente vinculado à dinâmica geral da sociedade e do Estado, partícipe das modificações requeridas pelo desenvolvimento social e político. Logo, "leis" como a da hipertrofia burocrática só valem para determinadas condições históricas e não podem ser tomadas como categorias atemporais, como sugerem alguns autores.

Assim, a teoria dos partidos de Cerroni - de clara inspiração gramsciana - parece responder mais adequadamente ao estudo dos partidos comunistas que aquelas oferecidas pelas diversas vertentes do pensamento liberal. Não apenas por acentuar o caráter histórico das formações partidárias, mas por vinculá-las à dinâmica das sociedades como aparelhos político-culturais, para usarmos um termo de Gramsci.

\subsection{O PCB na historiografia brasileira}


Como vimos, há na historiografia contemporânea diferentes formas de abordar a trajetória dos partidos políticos. Essa variedade de abordagens se deve, dentre outros fatores, à aproximação que as controvérsias existentes no âmbito da Ciência Política tiveram com a História, transformando o estudo dos partidos num típico campo interdisciplinar de trabalho.

No caso dos partidos comunistas, e do PCB em particular, a variedade de interpretações torna a empreitada ainda mais difícil, já que a amplitude dos estudos sobre o partido, ao mesmo tempo em que fornece uma ampla base de dados para a pesquisa histórica, contrapõe diferentes interpretações dos mesmos fenômenos. Daí o porquê de, apesar da abundância de trabalhos sobre o PCB, o partido seguir sendo objeto de trabalho dos historiadores, direta ou indiretamente ${ }^{27}$.

O PCB é de longe o partido mais estudado pelos historiadores brasileiros. São centenas de obras que seguem analisando as origens do partido, suas diferentes "fases", suas formas de organização, sua cultura política, a memória construída em torno de si, e mesmo sua extinção ${ }^{28}$.

Além disso, há inúmeros trabalhos sobre a relação do partido com a Internacional Comunista, os impactos das transformações ocorridas no interior do movimento comunista internacional, os sistemas de alianças desenvolvidos em diferentes momentos históricos, os influxos teóricos que tiveram impacto sobre o partido (em especial, no surgimento de dissidências), além de uma infinidade de pesquisas sobre personagens históricos cuja trajetória está profundamente ligada ao "partidão".

Comecemos, pois, acentuando mais uma vez a especificidade histórica dos partidos comunistas, lembrando que, diferente de outros partidos estritamente nacionais, o PCB como todos os partidos comunistas na primeira metade do século XX - fazia parte do que chamamos a pouco de "movimento comunista internacional". Essa característica foi exaustivamente abordada por dezenas de estudos a partir de uma disjuntiva fundamental para o entendimento dos partidos comunistas no período estudado: qual o grau de influência que a

\footnotetext{
${ }^{27}$ Dois dos mais importantes fenômenos editoriais na área da história, publicados nos últimos anos, versam sobre personagens que marcaram profundamente a história do PCB e da esquerda brasileira em geral: Luís Carlos Prestes e Carlos Marighela. Cf. REIS FILHO, D. A. Luís Carlos Prestes. São Paulo: Companhia das Letras, 2014; MAGALHÃES, M. Marighela - o guerrilheiro que incendiou o mundo. São Paulo: Companhia das Letras, 2012.

${ }^{28}$ Rigorosamente, o Partido Comunista Brasileiro, fundado em 1922, foi extinto em seu X Congresso Nacional, realizado em março de 1992. Naquele fórum, a maioria dos delegados presentes decidiu por extinguir a agremiação e criar em seu lugar o Partido Popular Socialista (PPS), seguindo o curso de outros PCs que optaram pela autoextinção após o fim da URSS. Isso não significa, no entanto, que não reconheçamos no partido que hoje leva o nome de PCB (registrado junto ao Tribunal Superior Eleitoral só em 1996) a tentativa louvável de manter vivo o legado do partido criado em Niterói, sete décadas antes. Esse reconhecimento e a simpatia que pode ensejar, no entanto, não estão acima dos fatos históricos.
} 
Internacional Comunista (até sua extinção, em 1943) e o Partido Comunista da União Soviética (PCUS) exerceram sobre os demais partidos comunistas no mundo? A resposta a essa pergunta pode ensejar distintas interpretações sobre a história do PCB. Se, como Paulo Sérgio Pinheiro ou Ronaldo H. Chilcote ${ }^{29}$, acreditarmos que o partido era pouco mais que um apêndice de seu homônimo de Moscou, então a leitura da história do partido estará determinada por essa condição. Se, ao contrário, considerarmos, como Marcos Del Roio, que apesar da profunda ligação do PCB com o movimento comunista internacional e sua direção soviética, o partido guardava nível razoável de autonomia - conforme demonstram experiências notáveis, como a criação da Aliança Nacional Libertadora (ANL), meses antes da tática das Frentes Populares ser aprovada pela Internacional Comunista - então as possibilidades de interpretação da história do PCB se ampliarão enormemente ${ }^{30}$.

Esse é apenas um exemplo das muitas controvérsias historiográficas envolvendo o PCB. Nossas opções, descritas ao longo do presente capítulo, não nos eximem da necessidade de apresentar outras abordagens possíveis com as quais nos bateremos ao longo deste trabalho e que podem, mesmo que partindo de premissas teóricas distintas, agregar enorme contribuição às interpretações aqui desenvolvidas.

É o caso da já mencionada proposta de análise a partir da noção de cultura política. Pelo menos duas obras merecem ser mencionadas como exemplo de contribuição teórica, pois, embora não sejam predominantes neste trabalho, aportam importantes elementos para o entendimento da dinâmica do PCB no interior da Assembleia Constituinte de 1946, objeto último deste trabalho. Refiro-me aos estudos de Dulce Pandolfi, Camaradas e Companheiros - História e Memória do PCB (1995), e de Jorge Ferreira, Prisioneiros do Mito: cultura e imaginário político dos comunistas no Brasil (2002), ambos referenciados nos novos estudos da história política e no conceito de cultura política. Utilizando uma vasta bibliografia combinada a dezenas de relatos de antigos militantes e dirigentes do PCB, Pandolfi busca reconstituir a autoimagem que o partido tinha de si mesmo, em diferentes momentos históricos, para compreender como esse elemento subjetivo influenciou opções táticas ao longo do tempo, num cenário que invariavelmente impediu a realização da prometida revolução, objetivo final do partido. Com essa preocupação, Pandolfi destaca que:

\footnotetext{
${ }^{29}$ Para aprofundar o tema Cf. PINHEIRO, P. S. Estratégias da Ilusão: a revolução mundial e o Brasil (19221935). São Paulo: Companhia das Letras, 1991; e CHILCOTE, R. H. Partido Comunista Brasileira: conflito e integração. Rio de Janeiro: Edições Graal, 1982.

${ }^{30}$ Para conhecer a posição de Marco Del Roio sobre o tema cf. DEL ROIO, M. O impacto da Revolução Russa e da Internacional Comunista no Brasil. In: REIS FILHO, D. A.; MORAES, J. de. História do Marxismo no Brasil. Vol. 1. Campinas: Editora da Unicamp, 2007.
} 
$\mathrm{Na}$ prática, os partidos comunistas que não conseguiram tomar o poder, ou seja, todos os partidos comunistas não-governamentais, como foi o caso do PCB, enfrentaram uma profunda contradição. Concebidos em função de uma irreversível crise do capitalismo e tendo como objetivo realizar uma revolução em escala mundial, esses partidos se defrontaram com outro contexto histórico. Diferentemente do previsto, conviveram com um sistema capitalista relativamente estável e tiveram que atuar tanto em regimes liberais-democráticos como em regime autoritários, abertamente anticomunistas. (1995, p. 61)

Essa contradição, que marca toda a trajetória do PCB (e das organizações comunistas que atuam nos marcos da legalidade liberal-democrática em geral), é um elemento fundamental para entendermos a relação de seus militantes, nas suas diversas frentes de atuação, com os setores sociais com os quais o partido se relacionava; seu sistema de alianças e a tática de cada período. No mesmo sentido, Jorge Ferreira aprofunda ainda mais a análise da cultura e do imaginário político dos comunistas brasileiros, buscando localizar as representações do "sagrado" como elemento constitutivo da vida social dos integrantes do PCB, e como o marxismo transformou-se num dogma para gerações inteiras de dedicados militantes comunistas. Não por acaso o partido foi descrito como o "santo dos santos, para nós e para a classe operária” pelo Comitê Central do PCB, em 1955 (FERREIRA, 2002, p. 36). Demonstrando mais uma vez a especificidade dos partidos comunistas, lembra que ele se apresentava como a organização que "decifrava o conhecimento do passado, não se confundia com as quimeras do presente e dominava os códigos do futuro, verdadeiramente grandiosos da humanidade" (Ibid. p. 40).

Na mesma trilha de Jorge Ferreira, mas radicalizando-as, também Daniel Aarão Reis Filho aponta a força de aspectos psicológicos e culturais fortemente presentes no interior dos partidos comunistas. Analisando as chamadas "organizações de estado-maior", que nos anos 1960 e 1970 travavam a luta contra a Ditadura Militar, quase sempre grupos político-militares de inspiração leninista, Reis Filho aponta características gerais que também podem ser encontradas na cultura política presente no PCB dos anos 1940, tais como: o "complexo de dívida" para com o partido, ente que liberta os militantes; o "massacre das tarefas", que mantém os militantes sob permanente estado de tensão; a "celebração da autoridade", muitas vezes transformada em culto à personalidade e apologia dos chefes; a "síndrome da traição", que ronda permanentemente organizações que agem à margem da legalidade; a função legitimadora dos "modelos internacionais"; o elogio aos "intelectuais revolucionários", dentre outras $^{31}$.

\footnotetext{
${ }^{31}$ Em O Fantasma da Revolução (São Paulo: Edunesp, 1993), Marcelo Ridenti desenvolve uma dura crítica às interpretações de Daniel Aarão Reis Filho. Como lembra Brandão, "no fundo, igualando tudo sob o 'modelo da III Internacional', Reis Filho toma as características da decadência da esquerda - a absolutização das formas de
} 
Como fica claro nas contribuições de Ferreira, Pandolfi e Reis Filho, seria impossível abordar a história do PCB hoje sem levar em conta aspectos ligados à cultura, às representações e ao imaginário político, elementos que formavam a base da identidade do "ser comunista". No caso deste trabalho, que buscará compreender a dinâmica interna da bancada pecebista na Assembleia Constituinte, uma dinâmica fortemente marcada por esses e outros elementos, como a divisão social e intelectual do trabalho parlamentar, teremos forçosamente de recorrer às contribuições aportadas por esses estudos.

No entanto, há outras abordagens historiográficas que igualmente serviram de base para nossa compreensão acerca do período estudado. No campo da história intelectual, destacamos as obras de Gildo Marçal Brandão, A esquerda positiva - as duas almas do Partido Comunista - 1920-1964, publicada em 1997, e o artigo de João Quartim de Moraes, $A$ evolução da consciência política dos marxistas brasileiros, publicada na coletânea História do Marxismo no Brasil - Volume II (2007), como dois exemplos de abordagens complementares e que enfocam a evolução teórica e política do PCB.

Brandão propõe analisar em que medida uma "contra-elite" política, vinculada às classes subalternas e tardiamente comprometida com a formulação de um caminho nacional para o socialismo, contribuiu para o desenvolvimento capitalista e para a construção de uma ordem democrática para o país (BRANDÃO, 1997, p. 13). Para tanto, toma como problema central em seu estudo as razões pelas quais a questão democrática, que emerge com força a partir de 1945, passa progressivamente para o segundo plano em benefício da questão "nacional". Para responder a essa questão, analisa aspectos como o tipo de marxismo então praticado, a leitura do desenvolvimento capitalista vigente e as concepções de ação política predominantes para formular algumas hipóteses com as quais buscamos dialogar criticamente, em especial aquela que ressalta o caráter excepcional dos assensos de massa de 1942-1947, como momentos em que as tendências mais dogmáticas são sufocadas por uma dinâmica imposta pela luta política “de fora para dentro" (BRANDÃO, 1997, p. 51).

Por sua vez, João Quartim de Moraes oferece em seu artigo uma análise do percurso intelectual do marxismo brasileiro, destacando os esforços de legitimação teórica das teses do partido ao longo do tempo. Para isso, destaca os obstáculos propriamente intelectuais e teóricos para a construção de um programa capaz de interagir de forma "realista" com a realidade brasileira, apontando os antecedentes históricos e políticos com os quais os

organização e de luta, a radical estraneidade com o mundo da política real - como se fossem da esquerda em geral. Ao invés das organizações armadas serem consideradas, como tradicionalmente, expressões radicalizadas do pacifista PC, é este o assimilado ao modo como aquelas viam o mundo e a política” (1997, p. 36). Este tema será aprofundado no capítulo III deste trabalho. 
comunistas se depararam ao longo de seu desenvolvimento intelectual, bem como as dramáticas inflexões representadas pelo processo de "bolchevização" do partido ou pelo predomínio do raciocínio econômico como base da autonomização teórica do comunismo brasileiro.

Cabe destacar as inúmeras obras que compõem uma história propriamente cronológica do $\mathrm{PCB}^{32}$, expressa na produção de dezenas de historiadores. Essa primeira leva de estudos, anteriores à renovação crítica da historiografia acerca do PCB, engloba obras como as de José Antônio Segatto, Breve História do PCB (São Paulo: Ciências Humanas, 1981) e A Formação da Classe Operária no Brasil (Porto Alegre: Mercado Aberto, 1987); de Eliezer Pacheco, O Partido comunista Brasileiro, $1922-1964$ (São Paulo: Alfa e Ômega, 1984); de Leandro Konder, A democracia e os comunistas no Brasil (Rio de Janeiro: Edições Graal, 1980); de Nelson Werneck Sodré, Contribuição à História do PCB (São Paulo: Global, 1984); de Dinarco Reis, A Luta de Classes no Brasil e o PCB (São Paulo: Novos Rumos, 1985); de Boris Koval, História do Proletariado Brasileiro - 1857-1967 (São Paulo: Alfa e Ômega, 1982), bem como relatos e abordagens de antigos dirigentes do partido como os presentes em A Formação do PCB, de Astrojildo Pereira (Lisboa: Edições Prelo, 1976) e em O Partidão A luta por um partido de massas, $1922-1974$ (São Paulo: Hucitec, 1982), de Moisés Vinhas, ou ainda, em relatos memorialísticos como os de Agildo Barata, em Vida de um Revolucionário - memórias (Rio de Janeiro: Editora Melso, sem data), de Leôncio Basbaum, em Uma vida em seis tempos (São Paulo: Alfa Ômega, 1976) e de Octávio Brandão, em Combates e Batalhas (São Paulo: Alfa Ômega, 1978).

Até mesmo os trabalhos recentemente publicados por Anita Leocádia Prestes, como Os comunistas brasileiros: Luiz Carlos Prestes e a politica do PCB (São Paulo: Editora Brasiliense, 2010) podem ser considerados parte da leva de trabalhos inscritos na historiografia "tradicional" do PCB, embora problematizem questões anteriormente relegadas a um segundo plano pelos historiadores do partido. Essas obras, embora reúnam diferentes perspectivas acerca da história do $\mathrm{PCB}$, compõem um conjunto que poderia ser classificado como uma historiografia "pecebista".

Por fim, não podemos deixar de mencionar as obras que compõem a revisão crítica da história do PCB, revisão esta que tem início nos anos 1970, levada a cabo por historiadores

\footnotetext{
${ }^{32}$ Gildo Marçal Brandão considera as tentativas de reconstituir uma história geral do PCB como parte de uma historiografia "oficialista", uma vez que aceita as versões que o próprio PCB construiu de si mesmo. Exagerada, essa perspectiva ignora o papel que esses estudos cumprem na formação de um quadro geral da história do partido, onde a própria perspectiva de onde cada autor "fala" enriquece, a partir de sua vivência dentro ou fora do partido, as capacidades interpretativas de que dispomos hoje.
} 
brasileiros e estrangeiros, como: Raimundo Santos, em A primeira renovação pecebista (Belo Horizonte: Oficina de Livros, 1988); Ronald H. Chilcote, em Partido Comunista Brasileiro: conflito e integração (Rio de Janeiro: Edições Graal, 1982); John W. F Dulles, em $O$ Comunismo no Brasil (Rio de Janeiro: Nova Fronteira, 1985); Vânia Malheiros Barbosa Alves, em Vanguarda Operária: Elite de Classe? (Rio de Janeiro: Paz e Terra, 1984); e Evaristo Giovanetti Netto, no importante O PCB na Assembleia Constituinte de 1946 (São Paulo: Editora Novos Rumos, 1986), obra com a qual dialogamos centralmente no terceiro capítulo. Nestes últimos trabalhos são explorados os fundamentos do desenvolvimento histórico do PCB, fazendo aflorar as polêmicas que acompanham a produção historiográfica do "partidão" e que chegam às já mencionadas tentativas de interpretar a dinâmica do partido à luz da cultura política e da vida interna das organizações comunistas.

\subsection{O PCB e a Assembleia Constituinte: panorama historiográfico}

Nosso trabalho, como registrado na introdução à presente dissertação, busca analisar um determinado objeto - o PCB - inscrito num intervalo histórico, definido no ano de 1946, e num espaço - a Assembleia Constituinte. Analisar o PCB e a Assembleia Constituinte é quase como ter nas mãos dois objetos, tamanha é a complexidade dos estudos envolvendo esta e outras Constituintes. Ao mesmo tempo, o período que vai da aprovação da tese da "União Nacional com Vargas" (formalizada na Conferência da Mantiqueira, em 1943) até o fechamento do partido, em 1947, é considerado por muitos como um dos períodos mais ricos da história do PCB. Ainda assim, mesmo que obrigatoriamente mencionado nas abordagens mais globais da história do partido, a "guinada tática" do PCB foi estudada quase sempre como expressão da busca dos comunistas por localizar-se corretamente numa conjuntura de intensas transformações. Nesse contexto, a presença do partido na Assembleia Constituinte e a atuação de sua bancada são tomadas invariavelmente como mera reprodução da dinâmica geral que a política do PCB desenvolvia no período, sem que sejam esmiuçadas as características gerais da atuação de seus parlamentares e como estes se adaptaram àquele espaço francamente hostil aos comunistas.

Apesar dessa recorrente lacuna, há uma vasta bibliografia, tanto nos estudos históricos quanto na ciência política, que busca compreender esse rico momento da vida do PCB, desde sua reorganização (1943) e legalização (1945), até a cassação de seu registro (1947) e a proclamação de sua ruptura com a ordem liberal-democrática no chamado "Manifesto de 
Agosto" (1950). Como referência sobre o período de democratização dos anos 1940, citamos o já clássico PTB: do Getulismo ao Reformismo - 1945/1964 (São Paulo: LTr, 2011), de Lucília de Almeida Neves Delgado, que reconstitui o processo de formação daquela frágil experiência democrática a partir da perspectiva petebista, oferecendo, ao mesmo tempo, importantes elementos sobre a relação do partido de Getúlio Vargas com os comunistas naquele período. Contribuição semelhante nos traz Os Democratas Autoritários (São Paulo: Brasiliense, 1980), de João Almino, que estuda o tema das liberdades individuais, de associação política e sindical na Constituinte de 1946, temas caros à bancada do PCB. No campo das fontes bibliográficas, indispensáveis são as obras de Edgard Carone, $O P C B$ 1943 a 1964 (São Paulo: Editora Difel, 1982), e de Moisés Vinhas, O Partidão - a luta por um partido de massas (São Paulo: Hucitec, 1982), que reúnem os documentos publicados pelo Comitê Central do partido nesse período e permitem compreender os pressupostos da política de "união nacional" e seus mínimos detalhes.

Sobre a política do PCB no período temos diversos bons estudos, alguns privilegiando aspectos específicos da atuação do partido, outros abordando mais globalmente suas posições, seus "erros" e "acertos". No caso das obras que abordam um aspecto particular da ação do PCB no intervalo democrático destaca-se o denso estudo de Marco Aurélio Santana, Homens Partidos - comunistas e sindicatos no Brasil (São Paulo: Boitempo Editorial, 2001), especialmente seu primeiro capítulo, em que analisa a atuação do PCB na luta institucional. Aliás, o título do capítulo não poderia ser mais ilustrativo dos dilemas daquele momento histórico: "O partido e os sindicatos na redemocratização (1945-1947): o PCB na corda bamba".

Outras obras merecem ser mencionadas, seja pelo pioneirismo de privilegiar este período, seja pela variedade de interpretações que aportam. É o caso de Partido Comunista Brasileiro: conflito e integração (Rio de Janeiro: Edições Graal, 1982), do brasilianista Ronaldo H. Chilcote. Mesmo tendo como referência teórica para o estudo dos partidos as teorias de Duverger e Michels - o que leva o autor a "encaixar" o PCB nas "leis" propostas por esses autores - Chilcote oferece um panorama inicial das dificuldades enfrentadas pelo PCB diante de sua incorporação à institucionalidade liberal-democrática. No mesmo sentido vai o estudo John W. F. Dulles, O Comunismo no Brasil (Rio de Janeiro: Nova Fronteira, 1985), publicado pouco depois e com um capítulo dedicado aos anos 1940 e à relação do PCB com as instituições.

Trabalhos mais recentes aprofundaram os estudos acerca da presença do PCB na Assembleia Constituinte sobre diferentes perspectivas. Anita Leocádia Prestes aborda a 
influência das ideias de Luís Carlos Prestes sobre a linha do partido após sua legalização no já citado Os Comunistas no Brasil, especialmente nos capítulos III e IV. Leocádia, como observou recentemente Daniel Aarão Reis Filho, no entanto, peca por seu viés "defensivo, glorificante e retrospectivo" (REIS FILHO, 2014, p. 511). A propósito, as recentes biografias de Prestes e Marighela, escritas respectivamente por Mário Magalhães e Daniel Aarão Reis Filho, também trazem contribuições à compreensão do período estudado sobre outros vieses.

Ainda no marco das revisões críticas da história do PCB nos anos 1940 está a excelente coletânea Corações Vermelhos (São Paulo: Cortez, 2003), organizada por Antônio Carlos Mazzeo e Maria Izabel Lagoa, e que traz ao menos um artigo indispensável sobre os anos 1940 com o título de "Insistente Desencontro: o PCB a revolução burguesa no Brasil", de Lúcio Flávio Rodrigues Almeida. Na mesma direção vai o artigo de Fernando Teixeira Silva e Marco Aurélio Santana, "O equilibrista e a política: o 'Partido da Classe Operária' (PCB) na democratização (1945-1964)", publicado na coletânea organizada por Jorge Ferreira e Daniel Aarão Reis Filho, Nacionalismo e Reformismo Radical - 1945/1964 (Rio de Janeiro: Civilização Brasileira, 2007). Por fim, não podemos deixar de destacar o já mencionado livro de Dulce Pandolfi, Camaradas e Companheiros: história e memória do PCB, que enriquece os estudos sobre a política de "união nacional" na perspectiva da cultura política, com importantes depoimentos de militantes e dirigentes que viveram "os impasses da legalidade" (PANDOLFI, 1995, p. 144) e os usos políticos que a experiência de 1945 teria no processo de legalização do partido, quatro décadas depois.

Esses e outros trabalhos abordam, sobre diferentes perspectivas, a atuação do PCB na Assembleia Constituinte de 1946, via de regra, a partir de uma leitura mais geral da política do partido em curso naquela conjuntura. Poucos autores, porém, dedicaram-se a conhecer a atuação legislativa do partido, isto é, a tradução parlamentar de suas bandeiras de luta e agitação política. Sem isso, qualquer avaliação sobre a natureza da política sustentada pelo PCB naquele momento histórico parece-nos incompleta. Por isso, o presente trabalho tem uma espécie de "interlocutor oculto". A obra de Evaristo Giovanetti Netto, O PCB na Assembleia Constituinte de 1946, torna-se inevitavelmente uma referência com a qual mantivemos um permanente diálogo crítico, na medida em que se constitui como único estudo sistemático sobre a atuação do PCB na Constituinte de 1946. Tal diálogo objetiva enriquecer as contribuições sobre o tema e enfrentar alguns "mitos" que subsistem na obra de Giovanetti, como a obsessiva tese da consciente "colaboração de classes" levada a cabo pelo PCB no interior da Constituinte. 
Como o próprio autor admite, Giovanetti opta por uma abordagem estritamente superestrutural da análise do fenômeno. Por isso, seu trabalho limita-se a duas dimensões: a primeira, a experiência do PCB na esfera parlamentar, e a segunda, o PCB no contexto da transição do Estado Novo para o regime que o autor denomina "democracia autoritária" (NETTO, 1986, p. 2). Evidentemente, nossa proposta é considerar essas dimensões indispensáveis ao estudo do nosso objeto, um objeto inserido tanto na sociedade política quanto na sociedade civil. Porém, pretendemos ir além: desvendar a dinâmica interna da bancada do PCB e identificar os mecanismos exteriores e ulteriores que determinam seu funcionamento dentro e fora da Assembleia Constituinte, testando algumas hipóteses e apresentando algumas novas interpretações. 


\section{CAPÍTULO 2}

\section{DA TÁTICA DA “UNIÃO NACIONAL" AO PARLAMENTO BRASILEIRO}

Apesar do renovado interesse pela história do $\mathrm{PCB}$, a trajetória do mais longevo partido brasileiro ainda é repleta de lacunas. Mas aos poucos estas lacunas vão sendo preenchidas por sucessivas levas de trabalhos que abordam diferentes aspectos de sua história. José Antônio Segatto, estudando o período que vai da revisão crítica - iniciada em 1954, realizada pelo partido em relação ao chamado Manifesto de Agosto - até o golpe civil-militar de 1964, afirma que "a história do PCB não se explica por si mesma; ela só pode ser explicada por suas relações concretas com a sociedade e o Estado, com todas as mediações possíveis" (SEGATTO, 1995, p. 25).

O período de que trata este capítulo, a saber, da reorganização do partido na chamada Conferência da Mantiqueira (1943), quando foi oficializada a política da "união nacional com Vargas", até o início dos trabalhos da Assembleia Constituinte (1946), é extremamente controverso. Especialmente porque foi nele que o $\mathrm{PCB}$, entrando em contato com um novo ordenamento político-institucional, viu-se diante dos dilemas de ser um partido "dentro da ordem". Trata-se, portanto, de um período de "viragem" na política do partido e de ajustes na forma como ele interpretava as mudanças que o país e o mundo atravessavam.

A alteração de rota que o PCB inicia poucos anos após a malograda insurreição de 1935 já suscitou as mais apaixonadas discussões. Nosso objetivo, no entanto, é colocar a história em seu lugar. Como assevera Brandão:

\footnotetext{
O fato de que um movimento ou programa políticos tenham sido superados não exclui, como se sabe, a possibilidade de terem sido válidos historicamente, cumprido uma função relativamente necessária. Um tal exame visará então tanto suas condições de possibilidade como seus limites, o que implica dizer que só poderá ser bem-sucedido se tomar como fio condutor a recuperação dos problemas reais com base nos quais aquelas respostas foram formuladas. (1997, p. 23).
}

Evidentemente, dicotomias como aquelas que opõem atualidade/superação, necessidade/possibilidade, são sempre complexas quando se trata de uma pesquisa histórica, embora não consideremos que essas são abordagens exclusivas de disciplinas como a sociologia ou da moderna ciência política. Nosso objetivo, em outras palavras, será construir 
um olhar compreensivo das condições históricas nas quais homens e mulheres, que construíram o Partido Comunista do Brasil como "elite política da classe operária", asseguraram sua intervenção no âmbito da Câmara dos Deputados durante um dado período de tempo específico. Não buscamos, ao contrário da historiografia crítica sobre o PCB dos anos 1980, apontar se o partido não pôde ou não quis liderar um dado processo histórico, antes, pretendemos examinar o papel desempenhado por ele na realidade concreta da democratização ${ }^{33}$ política dos anos 1940. Para tanto, comecemos identificando nosso objeto no interior das transformações que o Brasil e o mundo viviam naquele momento.

\subsection{O Brasil e o PCB num mundo em chamas}

No início dos anos 1940, o mundo estava mergulhado em incertezas. O conflito entre as potências do eixo (Alemanha, Itália e Japão) e os aliados (Estados Unidos, Inglaterra e União Soviética) se convertia em guerra total na Europa. Muitos se perguntavam até onde o nazifascismo poderia chegar. Para se ter uma ideia, só no ano de 1940 a Alemanha invadiu e conquistou os seguintes países: França, Noruega, Holanda, Bélgica, Luxemburgo e Dinamarca (no ano anterior Hitler já havia conquistado a Polônia e os Sudetos). No mesmo período são erigidos o campo de concentração de Auschwitz e o muro que formava o gueto em torno de Varsóvia, dando início à perseguição antissemita como política de Estado do nazismo.

No Brasil, as contradições diante deste cenário não podiam ser mais agudas. Governando com poderes ditatoriais desde o golpe que instituiu o Estado Novo, em 1937, o presidente Getúlio Vargas optou por manter uma posição de neutralidade diante do conflito na Europa. Só em 5 de junho de 1940, dez meses após a invasão da Polônia pelos exércitos de Hitler, o Brasil daria o primeiro passo concreto para a entrada na guerra ao lado dos aliados, aprovando em reunião ministerial a total colaboração industrial com o esforço de guerra desatado pelos Estados Unidos.

No plano interno, as mudanças processadas ao longo dos anos de 1930 aceleravam-se. Apesar da crise econômica que o mundo capitalista vivera no fim dos anos de 1920, com impactos severos sobre o Brasil, o país continuava se transformando. Entre 1930 e 1937, o

\footnotetext{
${ }^{33}$ Usaremos o conceito de democratização por compreendermos que a ideia de redemocratização é inexata quando nos referimos aos anos 1940. Consideramos, como Fernando Limongi, que a experiência democrática iniciada em 1945 é a primeira da história política do país, apesar de todas as suas enormes limitações históricas (LIMONGI, 2012, p. 38).
} 
Produto Interno Bruto (PIB) cresceu em média 7\% ao ano. Entre os anos 1920 e 1940 o número de operários quase triplicou (de 300 mil para 800 mil) e ampliou-se a mecanização da produção agrícola nas áreas voltadas à exportação; o número de tratores, por exemplo, aumentou de 1700 unidades em 1930 para 8500 unidades dez anos depois. A inflação mantinha-se dentro de patamares razoáveis (entre 4\% e 7\% durante toda a década) e só com os impactos da guerra, no início da década de 1940, ela aumentaria, chegando a cerca de $15 \%$ ao ano (VINHAS, 1982, p. 67).

No final da década de 1930, já durante o Estado Novo, os serviços de estatísticas do governo promoveram pesquisas que atestaram as desigualdades regionais e sociais que marcavam o país. Foram pesquisados os orçamentos de operários, comerciários e empregados de categoria modesta, com renda não superior a $420 \$ 00$ por mês. A maior quantidade de salários concentrava-se na faixa entre 200\$000. Os trabalhadores dos municípios do interior recebiam menores salários e despendiam proporcionalmente mais com alimentação, vestuário, farmácia e atendimento médico do que os moradores das capitais, que, por sua vez, gastavam mais com habitação (ALBERTI, 2002, p. 296). Um trabalhador rural, no entanto, recebia salários bem menores. Os mais mal remunerados (cortador de cana, tratador de animais, apanhador de café, dentre outros) recebiam cerca de $4 \$ 000$ por dia. Ao final do mês, o salário dificilmente passava dos 100\$000, metade do salário médio de um operário (Ibid., p. 297). Como se nota, apesar de as condições gerais da economia serem estáveis (com crescimento relativamente alto e baixa inflação), a desigualdade mantinha-se como marca da estrutura social brasileira.

No plano político, embora se aproximasse dos aliados ocidentais, o governo de Vargas continuava guardando fortes características autoritárias. Enquanto os direitos sociais eram valorizados através de mecanismos que buscavam a inclusão sob controle estatal, o processo político seguia negando os princípios básicos da democracia liberal (DELGADO, 1997, p. 96). O governo apregoava a ideia de que uma sociedade unida pela busca de objetivos comuns não precisaria de canais para a expressão de conflitos indesejáveis - como o parlamento. À perseguição dos comunistas por ocasião do levante de 1935, seguiu-se a perseguição dos integralistas $^{34}$. Após o levante de março de 1938, o governo desatou uma forte campanha repressiva que culminou na prisão de Plínio Salgado, líder dos "camisas-verdes", em janeiro de 1939.

\footnotetext{
${ }^{34} \mathrm{O}$ integralismo era movimento político de extrema-direita, organizado na Ação Integralista Brasileira, de inspiração fascista, fundado em 1932 e extinto em 1937. Foi reorganizado em 1945 sob a sigla do PRP (Partido de Representação Popular).
} 
No início dos anos 1940 o equilíbrio entre política interna e externa tornava-se cada vez mais difícil. Ao mesmo tempo em que aceleravam os entendimentos diplomáticos com os Estados Unidos e reprimiam os grupos fascistas internos, Getúlio Vargas seguia expressandose de forma dúbia sobre o cenário internacional. Num discurso realizado a bordo do encouraçado Minas Gerais, Vargas falaria com simpatia acerca das mudanças que o mundo vivia, expressando indisfarçável simpatia pelos países do que mais tarde se conheceria como "eixo" Berlim-Roma-Tóquio. Mesmo com o constrangimento gerado pelas manifestações, consideradas por parte dos Estados Unidos favoráveis ao fascismo, o presidente brasileiro voltaria a manifestar-se nos mesmos termos, na Ilha do Viana, poucos dias depois (REIS FILHO, 2014, p. 215). Ao mesmo tempo, os desentendimentos com o governo inglês acerca do trânsito de navios brasileiros no Atlântico ampliou o mal-estar com os aliados e a disposição de Vargas em manter-se neutro ${ }^{35}$. Em março de 1941, o navio brasileiro Taubaté foi metralhado por aviões alemães enquanto cruzava o Mar Mediterrâneo, aumentando as pressões pela entrada do Brasil na guerra. A partir de então, tornaram-se recorrentes os ataques de submarinos alemães a embarcações brasileiras. Entre fevereiro e agosto de 1942 foram 22 barcos atingidos. O Brasil, no entanto, só declararia guerra ao Eixo em 31 de agosto daquele ano (SILVA, 1974, p. 67).

Enquanto isso, o PCB vivia um "intervalo" como organização política. Abatido pela repressão que se seguiu à insurreição de 1935, o partido estava disperso em diferentes núcleos com distintas leituras sobre a realidade do país e do mundo. A historiografia sobre o partido, embora seja farta sobre o período de reorganização do PCB, é quase inexistente quanto à situação dos militantes comunistas entre 1935 e 1943. As condições de vida dos pecebistas que resistiram a esse "intervalo" são praticamente ignoradas em quase todas as obras que abordam o partido nesse período.

Após o levante liderado pelo PCB em 1935, Vargas instituiu um Tribunal de Segurança Nacional para julgar quaisquer iniciativas subversivas. Dois anos depois, em meio aos preparativos das eleições presidenciais de 1938, o governo anunciou a descoberta de uma falsa conspiração comunista, intitulada "Plano Cohen". Com esse pretexto, Vargas materializou seu Golpe de Estado, fechando o Congresso Nacional e extinguindo todos os partidos políticos em novembro de 1937. Nascia o chamado "Estado Novo", inspirado nos regimes autoritários da Itália e de Portugal (CHILCOTE, 1982, p. 85). No ano seguinte, os

\footnotetext{
${ }^{35} \mathrm{Em} 1^{\circ}$ de dezembro de 1940 um navio da armada britânica deteve o navio mercante brasileiro Itapé e retirou de bordo 22 passageiros de nacionalidade alemã. $\mathrm{O}$ episódio originará protestos do diplomata brasileiro Osvaldo Aranha ante a embaixada britânica, no Rio de Janeiro.
} 
integralistas foram colocados na ilegalidade após uma malsucedida tentativa de tomada do Palácio Presidencial. A perseguição aos comunistas foi retomada e dezenas de militantes do PCB foram presos no final do ano de 1939. Em novembro desse ano Prestes é condenado pelo assassinato da jovem Elza Fernandes ${ }^{36}$.

No plano externo as resoluções da Internacional Comunista abandonavam gradualmente as concepções voluntaristas que marcaram a política do Comintern $^{37}$ desde o final dos anos 1920. A teoria da classe contra classe, que privilegiava uma associação automática entre a socialdemocracia e os movimentos nazifascistas como parte de uma mesma classe burguesa multifacetada, passava a ser substituída pela proposta de "frente nacional popular anti-imperialista”. Essa proposta foi formalizada entre julho e agosto de 1935, no VI Congresso Mundial da Internacional Comunista, sendo incorporada ao escopo teórico do PCB. A nova orientação, materializada na formação da Aliança Nacional Libertadora (ANL), não impediu, no entanto, o prematuro levante de novembro do mesmo ano (DEL ROIO, 2007, p. 97). Ainda assim as novas diretrizes formuladas pela liderança do movimento comunista internacional seguiriam repercutindo sobre o partido após a derrota de 1935 e alimentando muitas polêmicas entre os comunistas. Durante a preparação às eleições presidenciais de 1937, por exemplo, o partido se dividiu: algumas seções regionais defendiam o lançamento simbólico de Prestes como candidato, enquanto outros defendiam o nome do escritor paraibano José Américo de Almeida. A natureza dessa polêmica é controversa, havendo diferentes versões sobre $e^{38}{ }^{38}$. O que sabemos é que o então Secretário-Geral do partido, Lauro Reginaldo da Rocha, o "Bangu", venceu a disputa com o apoio da Internacional Comunista, ainda que a candidatura do escritor paraibano nunca tenha saído do papel devido ao golpe de 1937.

Paralelamente, o PCB seguia denunciando o caráter autoritário do governo de Vargas, afirmando que este preparava um "golpe militar-fascista" (SEGATTO, 1981, p. 49). Com o

\footnotetext{
${ }^{36}$ De acordo com Leôncio Martins Rodrigues, todo o secretariado nacional seria envolvido pelo caso da jovem Elza Fernandes (que se chamava, na verdade, Elvira Copelo). Companheira do Secretário-Geral do partido à época, Antônio Maciel Bonfim (o "Miranda"), Elza foi presa em janeiro de 1936, quando o PCB estava imerso em absoluta clandestinidade. Libertada dias depois, o Comitê Central do partido entendeu que Elza colocava em risco a segurança da organização e tomou a decisão extrema de eliminá-la. O crime só foi desvendado em 1940. Apesar de abominável, o autor ressalta, no entanto, que esta não foi uma prática adotada pelo PCB ao longo de sua história (RODRIGUES, 1997, p. 379).

${ }^{37}$ Comintern era a sigla pela qual era conhecida a Internacional Comunista.

${ }^{38}$ Entre todas as poucas e contraditórias explicações disponíveis, parece-nos mais confiável aquela oferecida por José Lauro Segatto, por parecer-nos melhor documentada, e segundo a qual a divergência situava-se nas condições para que o PCB outorgasse apoio a um dos candidatos que disputaria a eleição de 1937. Enquanto o grupo liderado por Hermínio Sachetta (e que romperia com o PCB em seguida) deveria dar apoio mediante a discussão de uma plataforma prévia. Para "Bangu", ao contrário, o apoio deveria ser concedido sem qualquer contrapartida programática por parte do candidato apoiado (SEGATTO, 1989, p. 50).
} 
aprofundamento da escalada repressiva e a decretação do Estado Novo, o PCB praticamente deixa de existir enquanto organização nacional. As ações do partido limitam-se a algumas iniciativas dispersas em São Paulo, Bahia e Rio de Janeiro e a inação parecia indicar a virtual extinção do PCB (CARONE, 1976, p. 217).

O governo Vargas, porém, dava sinais contraditórios que alimentavam entre os comunistas a esperança de que ele poderia vir a compor uma aliança nacional popular antiimperialista. Embora o governo buscasse controlar o movimento sindical e proibisse a organização política dos operários, Vargas tomou medidas de defesa da economia nacional, aumentando o imposto sobre as importações e taxando em $8 \%$ a remessa de lucros ao exterior. Ao mesmo tempo, a criação de uma indústria siderúrgica nacional foi interpretada por muitos comunistas como uma medida anti-imperialista.

Este elemento, aliás, é decisivo para a compreensão das mudanças táticas operadas pelo PCB no final da década de 1930, mudanças estas que levaram ao abandono da proposta de "revolução agrária anti-imperialista" da ANL em favor da "união nacional com Vargas". Não são poucos os historiadores que atribuem exclusivamente - ou predominantemente - às orientações da Internacional Comunista os ajustes táticos promovidos pelo partido a partir de 1938. No entanto, outros autores nos chamam a atenção para o fato de o fortalecimento do nacionalismo no Brasil ser uma tendência estimulada por diferentes frações políticas e, em particular, pelo Estado Novo, o que poderia ter favorecido o desenvolvimento de posições nacionalistas também entre os comunistas brasileiros.

Desde os anos de 1920, o PCB havia seguido as orientações da Internacional Comunista em favor de uma revolução "democrático-burguesa". Segundo este esquema teórico, levando em conta o atraso dos países "coloniais" ou "semifeudais", como o do Brasil, a tarefa central dos comunistas deveria ser a de estimular o desenvolvimento de um sistema capitalista forte, capaz de prover de operários a segunda fase da revolução, que teria um caráter efetivamente socialista (PRESTES, 2010, p. 39). O esquema era uma cópia das leituras de Lênin acerca do desenvolvimento capitalista na Rússia czarista e era mecanicamente transplantado pela IC para outras realidades. No decorrer dos anos 1930, com a ascensão do fascismo, ganhou força a proposta das "frentes populares antifascistas", que assumiram um papel central na estratégia comunista ao longo da década e que, no Brasil, manifestou-se na criação da $\mathrm{ANL}^{39}$.

\footnotetext{
${ }^{39}$ Marcos Del Roio chega a afirmar que a ANL foi criada independentemente das orientações da Internacional Comunista, destacando-a como uma "pioneira experiência de frente popular, antes mesmo que esta se realizasse
} 
Apesar do fracasso da experiência brasileira, as frentes populares foram bemsucedidas em outros países, como França, Espanha e Chile. Isso manteve viva, mesmo após a desastrosa experiência da ANL, a possibilidade da via da unidade antifascista como alternativa real aos comunistas brasileiros. Ademais, a política "frentista" alimentava-se de certo caldo de cultura que destacava o elemento nacional em detrimento do elemento puramente classista. Como destaca Anita Leocádia Prestes:

\begin{abstract}
Como procurei mostrar em trabalhos anteriores, o nacionalismo - ou seja, as propostas de caráter nacional-libertador - esteve cada vez mais presente na política do PCB, seja no início dos anos 30 , culminando com a participação dos comunistas na Aliança Nacional Libertadora e nos levantes antifascistas de 1935, seja no período posterior, de 1938 a 1945, quando o partido adotou a consigna de "União Nacional" com o próprio Getúlio Vargas visando derrotar o fascismo e alcançar a democracia. (PRESTES, 2010, p. 41).
\end{abstract}

Assim, o PCB alimentou-se do que Hobsbawm denominou "nacionalismo antifascista", que emergiu entre todos os setores democráticos no período da guerra (HOBSBAWM, 1990, p. 174). Não é estranho, portanto, que apenas um ano após o golpe do Estado Novo, denunciado pelo próprio PCB, os comunistas fossem tragados por um obsessivo antifascismo, no qual o partido e sua identidade comunista eram relegados a um segundo plano em relação ao "combate principal" contra o inimigo fascista. Em carta endereçada por Luís Carlos Prestes ao tenente Severo Fournier, escrita em 1938 na prisão, o líder pecebista apontou as prioridades dos "patriotas" brasileiros: democracia, nacionalismo (este expressamente descrito como sinônimo de emancipação econômica) e bem-estar do povo (PRESTES, 2010, p. 43). Não por acaso, ao descrever a emancipação econômica esperada, o cavaleiro da esperança apontara a "criação de uma indústria pesada e efetivamente nacional" (Idem). Pouco depois dessas linhas, Vargas daria início à criação da siderurgia pesada no Brasil. Estava pavimentado o caminho para a "união nacional" entre os comunistas e o ditador do Estado Novo.

\title{
2.2 A reorganização do $\mathrm{PCB}$
}

Como vimos, no final dos anos de 1930 processava-se um movimento contraditório de aproximação unilateral: enquanto o governo aprofundava seu caráter nacionalista e, ao mesmo tempo, ampliava a repressão contra os comunistas, o contingente restante do PCB fora da 
prisão deslocava-se para uma política de aproximação com o governo do Estado Novo. Nos anos de 1940 e 1941 quase não há registro de atividade política do PCB. Conforme destaca Moisés Vinhas, “o partido só subsiste pela ação de indivíduos e pequenos grupos isolados" (VINHAS, 1982, p. 73). No entanto, a situação do país diante do cenário da guerra começava a mudar. Os acordos de cooperação firmados com os Estados Unidos em 1941 e a entrada definitiva deste na Segunda Guerra Mundial, transformaram o conflito de guerra europeia em guerra das democracias ocidentais contra o nazifascismo. Para completar, a invasão da União Soviética, em junho de 1941, permitiu que os poucos comunistas que ainda resistiam às novas diretrizes se entregassem de corpo e alma à cruzada antifascista, redimindo-os em relação ao apoio prestado em favor do acordo de não-agressão, firmado anos antes entre Hitler e Stálin ${ }^{40}$.

Da prisão, Prestes conclamava a população à união nacional contra o fascismo e defendia o envio de tropas brasileiras para lutarem na Europa. Presentes nas organizações da sociedade civil, os comunistas buscavam influenciar entidades como a União Nacional dos Estudantes (UNE), a Ação Católica Brasileira (ACB) e os remanescentes do movimento tenentista para que se somassem à campanha contra o perigo nazifascista. Nesse processo de despertar das lutas sociais no país, ganhou força a necessidade de reorganização do partido. Desde meados de 1941, grupos dispersos reivindicavam a reestruturação nacional do PCB. Nesse momento já vigorava plenamente a tática de "união nacional" contra o fascismo, e a aproximação com o governo era total.

Com a entrada do Brasil na guerra, em 1942, e o apoio entusiasmado dos comunistas, a repressão diminuiu e as condições para a reorganização do partido melhoram (VINHAS, 1982, p. 73). Dirigentes experimentados, no entanto, questionaram a linha adotada e resistiram ao processo de formação de um novo comitê central, retardando a unificação dos grupos comunistas até 1943 (CHILCOTE, 1982, p. 89). Nesses primeiros anos da década de 1940 formaram-se três grupos: um deles, integrado por antigos militantes de São Paulo, mais afastado de Prestes, e dois outros que disputavam entre si a primazia da relação com o líder preso. Destes, um era formado por militantes oriundos da Bahia, mas que atuavam em São Paulo. O outro, era composto por jovens militantes do Rio de Janeiro e se autodenominava Comissão Nacional de Organização Provisória (CNOP), sob comando de Maurício Grabois e Amarílio Vasconcelos (Idem).

\footnotetext{
${ }^{40}$ O Pacto Molotov-Ribbentrop ou Pacto Nazi-Soviético foi um tratado militar firmado às vésperas da Segunda Guerra Mundial entre a Alemanha e a União Soviética, com vistas a impedir um confronto militar entre os dois países. Esse tratado definia uma paz de cinco anos entre Alemanha e URSS e criava condições para a invasão da Polônia, dos Países Bálticos e da Finlândia.
} 
O grupo da Bahia, liderado por Diógenes de Arruda Câmara, Carlos Marighella, Giocondo Dias, dentre outros, inicia contato com os demais, visando a reorganização do partido. Nas tratativas com os paulistas surgem resistências e os resultados não são positivos (SEGATTO, 1989, p. 53). No contato feito com o grupo da CNOP, mais vinculado a Prestes, a aproximação é bem-sucedida: são firmados entendimentos para a convocação de uma Conferência Nacional. Segundo Edgard Carone, esses entendimentos "se traduzem na aceitação da liderança de Prestes, que está preso. Os paulistas, por sua vez, se dizem contrários a esta liderança e acabam se marginalizando, enquanto os primeiros se ligam cada vez mais entre si" (CARONE, 1976, p. 232).

Convocada a II Conferência Nacional do PCB, que se realizaria em agosto de 1943 na Serra da Mantiqueira, surgem novas polêmicas entre os comunistas. Embora todos concordassem com a tática de "união nacional" contra o fascismo, havia diferentes ênfases em relação ao papel do PCB naquela conjuntura. O entendimento da $\mathrm{CNOP}$ em relação à "união nacional" é de que esta se inseria num esforço de guerra e que, portanto, nada deveria desviar os comunistas do foco principal: a luta contra o fascismo. Para alcançar esse objetivo, a aliança com o governo Vargas era estratégica, já que a vitória das forças aliadas levaria, inevitavelmente, a um avanço da democracia também no Brasil. Outro setor, liderado por Fernando Lacerda e influenciado pelas posições do Secretário-Geral do PC estadunidense, Earl Browder, defendia a extinção do PCB e a diluição da atuação dos comunistas no interior da "frente popular" contra o fascismo. Essa posição, impactada pela decisão de extinção da Internacional Comunista, tomada por Moscou em maio de 1943, assimilava as teses que afirmavam ser possível uma coexistência entre os países socialistas e as democracias liberais. Uma terceira posição, representada pelo núcleo paulista e liderada por Caio Prado Júnior, defendia a tática da "união nacional", no entanto, sem abrir mão das críticas a Vargas e sua ditadura (SEGATTO, 1989, p. 54). Realizada a Conferência da Mantiqueira, a posição da CNOP seria vitoriosa com o apoio do grupo baiano e de Prestes, que ainda se encontrava preso, mas que buscava influenciar os debates em curso. Sua importância era tamanha que ele acabara a Conferência eleito Secretário-Geral do partido, mesmo ausente. O documento intitulado "Ampliemos as bases para a União Nacional”, publicado em novembro de 1943 na revista Continental, esboça em linhas gerais as posições aprovadas na II Conferência Nacional do PCB:

A União Nacional há de ser a conjugação efetiva dos esforços de todos os patriotas do Brasil. São patriotas, independentemente dos matizes de suas opiniões políticas, os que aspiram para a Pátria bem-estar, progresso e cultura. [...] Evidentemente, 
essa união há de realizar-se em torno do Presidente Vargas, que dirige o país em guerra, postas de parte antigas pendências e dissensões, que, neste momento, não se podem alegar nem fazer prevalecer diante do quadro supremo da Pátria em luta, na mais difícil e penosa de todas as guerras (CARONE, 1982, p. 14).

Como se nota, o teor do documento abstrai completamente quaisquer outros temas e não apenas ignora, como chega a negar, os conflitos de classe. A posição vitoriosa na Conferência da Mantiqueira é clara: nenhuma dissensão, todo apoio ao governo de Vargas. Ao falar de "antigas pendências", nada faz lembrar que o partido havia sido dizimado, poucos anos antes, pelo mesmo governo ao qual agora outorgava seu apoio sem quaisquer reservas. Prestes foi, sem dúvida, um dos principais defensores e formuladores dessa linha política. Sobre o governo disse ele: Esta unidade, praticamente, pode e deve ser alcançada em torno do governo
constituído [...] e que já deu incontestavelmente grandes passos ao lado das Nações
Unidas: cortou relações com o Eixo, cedeu bases militares aos Aliados, de acordo
com a vontade nacional reconheceu o estado de beligerância, tem acompanhado a
política dos Estados Unidos e Inglaterra, assinou a carta do Atlântico, permite a
publicação de livros que nos dizem a verdade sobre a URSS, etc. (PRESTES, 2010,
p. 49).

Alguns anos depois, o próprio Prestes - criticando o documento final aprovado na II Conferência Nacional do $\mathrm{PCB}$, mas sem qualquer autocrítica às próprias posições questionaria a ênfase dada ao apoio incondicional no esforço de guerra, chamando a atenção para a necessidade de apontar a luta pela democracia no Brasil como elemento indissociável dessa luta. Para Prestes, "acertando no fundamental, não soube, no entanto, a Conferência assinalar que a luta pela guerra era inseparável da luta pela democracia no país" (Ibid., p. 50). Como se pode observar, as páginas da revista Continental deixavam transparecer não apenas um movimento tático de "trégua" com Vargas enquanto a guerra mundial durasse, mas também certo adesismo ao governo, posição que foi criticada posteriormente na primeira reunião do Comitê Central realizado após o registro do partido, em 1945.

A postura de apoio incondicional que o PCB mantinha em relação ao governo Vargas, porém, não era a única característica da política de "união nacional" que se desenvolveria após a reorganização do partido. Documentos publicados ao longo dos anos de 1943 e 1944 demonstram que o novo Comitê Central aprimorara as formulações oriundas da Mantiqueira. Na edição de $n^{\circ} 7$ da Revista Continental, publicada em março de 1944, por exemplo, o partido afirmava que, mais do que um esforço de guerra contra o fascismo, a "união nacional" era um movimento "pela pacificação da família brasileira" (CARONE, 1982, p. 18). O mesmo artigo menciona, como exemplos de união, a cooperação entre Cuba e Estados Unidos. No 
primeiro caso, Fulgêncio Batista é citado como governante que soube "interpretar os sentimentos democráticos de seu povo e unificá-lo" (Idem). Sobre os Estados Unidos, o artigo destaca a "união nacional" em torno do presidente Roosevelt, que compreendendo as necessidades históricas do momento, libertou o dirigente comunista Earl Browder, "o primeiro a lançar a candidatura de Roosevelt para um quarto período governamental, comparando o chefe do executivo norte-americano a Abraham Lincoln" (Idem). Como se vê, o fenômeno não era isolado. Enquanto nos EUA, o líder do PC estadunidense pregava "o início de uma era de colaboração íntima entre o campo socialista e os Estados Unidos", na Argentina, Vittorio Codovilla, secretário-geral do PC daquele país, acreditava que URSS e EUA poderiam encontrar saídas comuns aos problemas do desenvolvimento econômico em nível mundial. Em Cuba, os comunistas apoiariam o governo de Batista (que quinze anos depois seria deposto pelos guerrilheiros de Sierra Maestra) e, no Peru, o PC daquele país apoiara a candidatura de Manuel Prado, um representante da oligarquia liberal local (LÖWY, 2012, p. 28).

Num artigo publicado apenas dois meses depois, os comunistas voltaram suas baterias contra os "impacientes". Esses indivíduos, apesar de antifascistas, pecariam pela "falta de sensibilidade política" e pela busca de "soluções apressadas" que não compreendem a necessidade de "passar pelas etapas sucessivas e necessárias da sua evolução política" (CARONE, op. cit., p. 19). No mesmo artigo, os comunistas relegam abertamente a defesa do socialismo em favor da "cooperação", afirmando que alguns indivíduos:

[...] falando sobre o pós-guerra, através da imprensa, se referem ao socialismo como
a única solução para os problemas que se seguirão à vitória, sem levar em conta as
características históricas nacionais e o grau de desenvolvimento de cada país. Na
verdade, sobre o pós-guerra, o que existe de positivo são os princípios de
colaboração e solidariedade internacionais estabelecidos em Teerã por Churchill,
Roosevelt e Stálin, que criaram para cada povo possibilidades para o seu
desenvolvimento pacífico (Ibid., p. 20)

Mesmo a defesa da libertação dos presos políticos do governo Vargas era criticada pelos comunistas, para os quais "tudo isso é levantado como verdadeiras exigências, sem levar em conta que as desconfianças do passado ainda persistem" (Idem). Vemos, portanto, que a tática da "união nacional" vai se transformando gradualmente na tática da "união nacional com Vargas", com importantes desdobramentos sobre o partido. Essa nova etapa da tática implementada deixa de centrar-se exclusivamente no esforço de guerra e busca expandir a "união nacional" como modelo para o desenvolvimento das relações políticas do país em todos os níveis. A negação de quaisquer conflitos com a ordem vigente, sob pretexto do 
esforço de guerra, pouco a pouco vai moldando uma forte guinada conservadora na política do PCB. Mesmo os traços de browderismo, representado pelos constantes elogios aos aliados ingleses e, principalmente, estadunidenses, estão marcados pela ideia de que a "união nacional" deve ampliar-se, deixando de ser um processo excepcional gerado pelas necessidades da guerra e transformando-se em um projeto de desenvolvimento nacional. A noção de que a "união nacional" era um movimento pela pacificação da família brasileira talvez fosse a mais emblemática negação da fase insurrecional vivida anteriormente, tal como a crítica aos setores que reivindicavam o socialismo como projeto político para o pós-guerra.

Estas, no entanto, não eram as posições de todos os comunistas brasileiros. Mesmo o Secretário-Geral, Prestes, chegou a discordar desses pontos, respondendo a um documento de 1943, quando afirma que, além de apoiar o esforço de guerra do governo, os comunistas deveriam defender as liberdades populares e a anistia aos presos políticos (CHILCOTE, 1982, p. 90). O partido ainda viveu alguns durante anos dividido entre a CNOP - que dirigia a política do partido após formalizar a reorganização do PCB na Conferência da Mantiqueira e o Comitê de Ação - que reunia o grupo liderado por Caio Prado Júnior e que não tomou parte na reorganização do PCB em São Paulo. A transição que se iniciaria, no entanto, exigiria um esforço completo para colocar o PCB como reconhecido interlocutor político no novo período histórico que se iniciaria no pós-guerra. As opções desse curto período, no entanto, marcariam o partido e cobrariam seu preço por muito tempo.

\subsection{A transição de 1945: o PCB volta à legalidade}

Quando o exército soviético conquistou Berlim, em maio de 1944, o Brasil ainda era governado por um presidente que se mantivera no poder graças a um golpe de Estado. As transformações em curso com a eminente vitória dos aliados (embora a guerra no Pacífico ainda estivesse indefinida) não atingiam apenas a política do PCB: a pressão por novas eleições aumentava cada dia mais e Vargas estudava a melhor forma de conduzir a transição de modo a não perder o controle sobre o processo de formação de um novo sistema político. Enquanto os grupos de oposição ganhavam força, Getúlio fortalecia seus laços com as massas e com os setores sociais que eram representadas pelo Estado Novo. Segundo Octavio Ianni, o

objetivo era "evitar que o poder político fosse para as mãos das oligarquias remanescentes e seus aliados liberais e estrangeiros. [...] Estavam em jogo na democratização do Brasil tanto interesses de grupos conservadores como interesses econômicos estrangeiros" (IANNI apud SEGATTO,1989, p. 57). 
Com o fim da guerra, as pressões aumentavam. Ocorriam protestos contra o custo de vida e em defesa do emprego. Em janeiro de 1945 reuniu-se o primeiro Congresso dos Escritores, muitos deles identificados com os comunistas, que aprovava um posicionamento favorável à realização de eleições livres, democráticas e secretas. Às tradicionais forças oligárquicas somavam-se numerosos outros setores de oposição a Vargas - inclusive progressistas e de esquerda - o que foi tornando sua situação cada vez mais difícil. Ainda no primeiro semestre de 1945, o governo anunciou a realização de eleições livres, concedeu a anistia aos presos políticos, permitiu a legalização dos partidos (inclusive o PCB) e alimentou a campanha da "Constituinte com Getúlio" para manter o controle sobre a transição (VINHAS, 1982, p. 77).

Como destaca Luiz Werneck Vianna: em termos políticos, restaurava-se o constitucionalismo liberal que se procurava fazer conviver com a agenda nacionalista do esforço modernizante, este que previa a estatização das jazidas minerais, a nacionalização dos bancos de depósitos e a criação de indústrias de base, dentre outros. Já em 1944, porém, com o progressivo abandono do regime corporativo-autoritário, instituído pelo Estado Novo por meio das principais facções das classes dominantes, e com o isolamento político de Vargas, este proporá um novo sentido para a mobilização das classes subalternas (VIANNA, 1978, p. 248). Apesar de ambos defenderem uma democratização "pelo alto", as tensões entre Vargas e setores das elites aumentavam e, diante da pressão de setores das forças armadas, Getúlio renunciou em outubro de 1945. Num ano em que a democratização fora tema constante nos debates políticos, é emblemático que o marco inicial deste processo tenha sido um novo golpe militar, fato quase pitoresco, não encerrasse em si características de ruptura e continuidade que marcaram o processo de transição. Como afirma Lucília Neves Delgado:

A desestruturação do Estado Novo, entendida como um processo basicamente de
modificação política, comportou dois níveis de realidade que deram uma conotação
especial àquela conjuntura de transiçãa. Por um lado, esboçaram-se as características
do rompimento e da oposição que, sem dúvida alguma, foram carros-chefes do
desencadeamento do processo de desestabilização do Estado Novo. De outro lado,
articularam-se de uma forma que, à primeira vista, pode parecer paradoxal, pois
elementos de continuidade mantiveram-se ativos no interior do próprio processo de
transformação. A transição comportou, portanto, elementos de manutenção e de
ruptura da ordem. [...] A formação do pluripartidarismo, ocorrida naquele mesmo
ano, espelhou com clareza a duplicidade do processo (DELGADO, 2011, p. 31).

Como vemos, trata-se de uma "conjuntura de transição", cujo equilíbrio entre elementos de ruptura/continuidade esteve presente todo o tempo. Como destaca Octávio Ianni, 
as instituições jurídico-políticas reaproveitadas da ditadura do Estado Novo, e as criadas em 1946, favoreciam uma democracia burguesa razoavelmente autoritária. As greves operárias eram com frequência reprimidas com violência e apenas dois anos após sua legalização o PCB teve seu registro cassado (IANNI, 2004, p. 273). Mas não se pode ignorar que, assim como o novo regime político mantinha aspectos herdados do período anterior, ele também ensejou diversas novidades.

Uma das mais notáveis de tais instituições, e que nos interessa particularmente, foi a de um sistema político pluripartidário. A lei eleitoral de maio de 1945, elaborada pelo Ministro da Justiça, Agamenon Magalhães, permitia a constituição de partidos unicamente de caráter nacional, diferentemente do período anterior ao Estado Novo, quando eram permitidos partidos regionais. Esse aspecto simbolizava um salto de "modernização" do sistema político, que nesse aspecto passava a se assemelhar às principais democracias ocidentais.

Entre 1945 e 1965 atuaram cerca de 12 partidos. As principais siglas criadas após a instauração do pluripartidarismo foram a União Democrática Nacional (UDN), o Partido Social Democrático (PSD) e o Partido Trabalhista Brasileiro (PTB). Além destes, outros partidos foram criados no decorrer do processo de democratização, como Partido Social Progressista - ao qual pertencia o ex-interventor de São Paulo, Adhemar de Barros -, o Partido Democrata Cristão (PDC), o Partido Republicano (PR), o Partido Libertador (PL) e o Partido da Representação Popular (PRP), abrigo dos integralistas remanescentes (SOARES, 2001, p. 86).

Os três maiores partidos representavam diferentes extratos da sociedade brasileira e tinham origens distintas. A UDN, reunindo uma ampla frente com pouca coesão ideológica, tinha como centro a ferrenha oposição a Vargas. O caráter de frente oposicionista reunia diferentes posições do espectro político brasileiro, da Esquerda Democrática (que mais tarde daria origem ao Partido Socialista Brasileiro), passando por representantes das oligarquias que, de alguma forma, foram prejudicadas pelos anos de Estado Novo, até antigos getulistas ressentidos (Ibid., p. 95). No entanto, as bases de classe da UDN eram formadas por setores bem definidos: profissionais dos setores médios com alta qualificação (médicos, advogados, engenheiros, jornalistas, professores e industriais). Em sua ata de fundação, a UDN não conta com um único trabalhador manual. Num primeiro momento, ela foi um dos partidos mais fortes dos centros urbanos, representando o sentimento antigetulista em suas variadas expressões (antiestatismo, moralismo, elitismo etc.).

Outro partido importante era o Partido Social Democrático, uma das agremiações partidárias incentivadas por Getúlio no processo de transição. Ciente de que não poderia 
manter na mesma agremiação trabalhadores assalariados, líderes trabalhistas, chefes de oligarquias e interventores do Estado Novo, Vargas optou por incentivar a criação de dois partidos totalmente distintos: o PTB e o PSD. Em comum havia apenas o apoio ao líder máximo do país. Entre as principais características do partido estavam a forte descentralização (apesar de haver sido criado "de cima para baixo") e o poder dos diretórios regionais, como numa extensão do poder dos governadores, característica da Primeira República (Ibid., p. 87). Tendo origem como um partido de quadros, formado por ex-interventores, prefeitos e governadores, o PSD reunia lideranças fisiológicas com alto potencial eleitoral, que dependiam muito da máquina pública. Ainda assim, abrigando proprietários de terras, comerciantes e profissionais das pequenas cidades, tinha por si só um gigantesco potencial eleitoral. Maciçamente apoiado pelo eleitorado do interior do país, o PSD equilibrava posturas conservadoras e modernizantes. Suas posições diante das reformas preconizadas pelos comunistas, no entanto, eram essencialmente conservadoras, opondo-se a quaisquer medidas de caráter estrutural, como a reforma agrária, a reforma administrativa ou a extensão da legislação trabalhista ao campo (HIPPÓLITO, 1985, p. 49).

Concluindo as principais novidades do quadro partidário estava o PTB. O partido se dispunha a absorver os mesmos setores sociais que o PCB buscava representar: os trabalhadores urbanos e industriais. Contudo, criado sob a influência direta de Vargas, o PTB acabou sendo uma "segunda via" do varguismo, simbolizando a continuidade e a ruptura que a transição trazia consigo (DELGADO, 2011, p. 35). A primeira via seria o PSD, que representava os setores rurais vinculados ao poder local dos interventores, enquanto a segunda seria o PTB, representando o ideal do "trabalhismo" e os interesses dos trabalhadores urbanos assalariados. Nesse contexto o partido foi essencial como elo da manutenção entre os elementos do período anterior - o corporativismo e o controle por parte de Vargas do movimento operário - e os novos elementos da democratização - a liberalização política e a livre organização partidária (Idem). Assim, o principal objetivo do PTB era agrupar os trabalhadores em torno de uma legenda forte, identificada com as conquistas sociais do período anterior e capaz de defender os interesses corporativos destes setores.

Porém, o PTB não buscava apenas assegurar a influência de Vargas sobre os trabalhadores assalariados: também se dispunha a servir de anteparo à influência dos comunistas sobre esses setores sociais. Durante seu processo de reorganização o PCB crescera muito. De aproximadamente cem militantes ativos em 1942, subiu para quase três mil em 1943, alcançando cinquenta mil membros às vésperas de sua legalização, em 1945. No final do mesmo ano, o partido contava com quase duzentos mil filiados (SEGATTO, 1989, p. 56). 
Os getulistas, diante do crescimento do PCB, viram-se forçados a criar seu próprio instrumento de ação partidária, capaz de neutralizar ou bloquear o forte potencial expansionista que o PCB demonstrara em seus poucos meses de legalidade (DELGADO, 2011, p. 43). O próprio Getúlio, em suas anotações, destaca expressamente essa preocupação:

\begin{abstract}
Não há a menor dúvida de que a grande massa não é comunista, e normalmente, com uma orientação segura, ponderada e dentro da realidade, o Partido Comunista terá pouca possibilidade no Brasil. Não podemos, porém, subestimar o trabalho desse partido... não há dúvida de que, se não formos à Constituinte, dando assim ao povo possibilidade de votar em representantes que pelo menos lhes deem esperança da continuação do Presidente Vargas, uma percentagem considerável votará com o Partido Comunista, mais como protesto e menos como adepta essa ideologia (VARGAS apud DELGADO, 2011, p. 44).
\end{abstract}

Como vemos, o PCB era percebido como um importante ator no processo de transição. Não era para menos. O partido engajara-se decididamente no combate ao nazifascismo, apoiara as ações de Vargas no período mais crítico da guerra, ampliara sua influência de massas e ajustara seu discurso na defesa de um tímido programa de reformas, abandonando a retórica em torno da luta de classes e do socialismo. Naquela conjuntura, o realismo do PCB era uma forte ameaça à influência varguista sobre os trabalhadores.

Para os comunistas, o fim do Estado Novo era uma grande vitória. Embora a renúncia de Vargas só tenha ocorrido em outubro, as atividades do PCB já eram públicas ao longo de todo o ano de 1945. De fato, a leitura de que a vitória dos aliados na guerra aceleraria a democratização do Brasil, enfim, confirmava-se. Com a libertação de Prestes, em abril, o partido ganhou grande impulso. Em sua primeira aparição pública, desde que deixara a prisão, Prestes apontou as linhas gerais da atuação do partido no processo de democratização, num discurso proferido no estádio de São Januário, em 23 de maio, com a presença de alguns milhares de presentes:

Esta é a nossa posição, a linha política de nosso partido - unificação nacional para iniciar a solução dos graves problemas econômicos e sociais e chegarmos, de maneira pacífica, através de eleições livres e honestas, à Assembleia Constituinte e à reconstitucionalização democrática que todos almejamos (PRESTES apud CARONE, 1982, p. 31).

O centro do programa do PCB continuava sendo a defesa da "união nacional" e da liderança de Vargas no processo de transição. Mas há outros elementos que merecem destaque. Os comunistas defendiam uma série de medidas emergenciais que deveriam ser encampadas pelo novo parlamento e que esboçavam o programa do partido naquele espaço, tais como: a) combate ao capital estrangeiro e defesa da indústria nacional; b) amplo direito 
de organização sindical; c) combate à inflação; d) entrega de terras gratuitas às famílias dispostas à produção de bens para o abastecimento dos centros urbanos; e) redução do imposto do consumo e de todos os impostos sobre as trocas internas; f) aumento progressivo do imposto sobre a renda e criação de um novo imposto sobre o capital; g) elevação geral do salário, com aumento de real de 100\% do salário mínimo (CARONE, 1982, p. 35).

Como se vê, embora trate-se de um programa reformista de caráter radical para a época (e ainda para os nossos dias), a plataforma comunista estava há anos-luz das propostas de ruptura que antecederam a adoção da tática da "união nacional". No entanto, embora expressasse um conteúdo radical, de caráter anti-monopolista, anti-imperialista e antilatifundiário, o programa do PCB estava subordinado a uma tática de colaboração de classes. Para os comunistas, esse programa só poderia ser implementado pela cooperação entre todos os elementos comprometidos com o "progresso" da nação.

Nesse espírito, os comunistas combateram as forças oposicionistas que exigiam a renúncia de Vargas e, portanto, a divisão da nação. Prestes afirmara, no mesmo comício, que a saída do presidente "seria uma deserção e uma traição que não contribuiria de forma alguma com a união nacional" (CARONE, 1982, p. 36). Para dar o exemplo de compromisso com a transição pacífica sob comando de Vargas, o PCB se colocou como "esteio máximo da ordem e da lei". Conforme o partido, o momento era decisivo pois opunha o caos à "união nacional", a desordem à democracia, a guerra civil ao desenvolvimento pacífico. Como vemos, o PCB desembaraçava-se de quaisquer resquícios insurgentes, declarando-se comprometido com a transição levada a cabo pelas elites nacionais. Mas as manifestações públicas dos comunistas refletiam corretamente suas preocupações?

Quando se reúne pela primeira vez o pleno do Comitê Central do PCB, em agosto de 1945, novas questões surgem. O tom do documento intitulado Os comunistas na luta pela democracia, assinado por Prestes e aprovado naquela reunião, era mais analítico e menos propagandístico. Colocava no centro da agenda dos comunistas as tarefas do processo de democratização e apontava elementos de balanço em relação à atuação do partido no período anterior. Sobre a Conferência da Mantiqueira, o documento criticava o apoio "incondicional" ao governo. Segundo ele:

Acertando no fundamental, não soube a Conferência assinalar que a luta pela guerra era inseparável da luta pela democracia no país e, adotado, de maneira um pouco esquemática a política de apoio ao governo, não soube mostrar ao Partido e ao próprio governo o quanto seria este reforçado e o quanto seria mais sólida a união nacional, à medida que fossem dados passos no sentido da democracia, especialmente com a libertação dos presos políticos e a suspensão da censura à imprensa e restrições às liberdades civis (CARONE, 1982, p. 52). 
A linha política no período imediatamente posterior a 1943, como se vê, passara dos limites. Até os apelos em relação à "união da família brasileira", publicados na revista Continental em 1943, seriam criticados por Prestes. Para ele, a pacificação reivindicada pelo partido era unilateral, pois "nenhuma palavra se escrevia a favor dos que sofriam nas mãos do governo". Para Prestes, tratava-se de apresentar críticas “construtivas e serenas" aos erros do governo, ajudando este a se livrar dos elementos fascistas que ainda ocupavam posições no Estado brasileiro (Idem). Além disso, o Secretário-Geral do PCB insistia ainda na denúncia do Golpe de Estado em gestação por parte das forças reacionárias. Como se nota, mesmo as formas de encarar a transição e o apoio ao governo foram temas controversos no interior do PCB, tamanho o impacto das transformações em curso.

Pouco antes, o governo Vargas aprovara a Lei dos Atos Contrários à Economia Nacional, apelidada rapidamente de "Lei Antitruste", o que dificultou as operações dos monopólios estrangeiros no Brasil. Junto à lei, foi criada uma Comissão de Defesa Econômica com poderes para expropriar empresas que infligissem a segurança econômica e os interesses nacionais (REIS FILHO, 2014, p. 230). A lei, repudiada veementemente pelo embaixador dos Estados Unidos, foi vista como demonstração do compromisso de Vargas com um processo de desenvolvimento genuinamente nacional e deu novo argumento para a manutenção da aliança dos comunistas com o Ditador.

Na mesma reunião em que Prestes tecera suas críticas à orientação política do partido nos anos de 1943 e 1944, o PCB aprovou posição contrária à realização de novas eleições presidenciais antes da Assembleia Constituinte. Argumentava afirmando que qualquer eleição realizada sob a Constituição de 1937 (a "Polaca" do Estado Novo) não poderia ser aceitável, pois elegeria apenas mais um governo com poderes vastos e arbitrários, conforme previa aquela Carta.

Em meio à batalha pelo controle da transição política, Vargas incentiva um movimento em torno da proposta de realização da Assembleia Constituinte sem eleição presidencial, assim como defendido por Prestes e o PCB. O movimento difundiu nacionalmente a palavra de ordem "Queremos Vargas", tornando-se conhecido por isso como "movimento queremista". Motivado diretamente pelo Ministério do Trabalho, o movimento queremista confundia-se com os primeiros meses de vida do próprio trabalhismo, desaguando em grande medida no fortalecimento do PTB. No entanto, não devemos supervalorizar o papel do queremismo naqueles meses de 1945: o movimento queremista não foi mais que uma manifestação conjuntural, uma mobilização político-social que coincidiu, em seus objetivos, 
com uma das premissas iniciais do PTB, a saber, a preservação do mito de Vargas e da obra social trabalhista (DELGADO, 2011, p. 50).

A participação dos comunistas no movimento queremista é controversa. A historiadora Anita Leocádia Prestes, por exemplo, refuta a noção corrente de que os comunistas tomaram parte ativa no movimento queremista, mesmo que a consigna central do movimento coincidisse com a política recém-aprovada pelo partido, como vimos há pouco. Para ela, “os documentos da época relevam que, em momento algum, o PCB ou Prestes defenderam a palavra de ordem de 'Constituinte com Getúlio', bandeira do movimento queremista" (PRESTES, 2011, p. 73). O informe de Prestes à primeira reunião legal do Comitê Central do PCB (o chamado "Pleno da Vitória"), porém, contestava a versão de que os comunistas eram contrários à continuidade de Vargas durante a Constituinte. O que significa sua posição crítica diante de eleições realizadas “sob a carta de 1937”, senão um apelo em favor da realização da Assembleia Constituinte sob a condução de Vargas? No mesmo sentido vão as críticas do partido às duas candidaturas então apresentadas (Eurico Gaspar Dutra, pelo PSD, e Eduardo Gomes, pela UDN).

A mesma dúvida não pode ser levantada em relação à presença comunista no movimento queremista. Embora seja verdade que nos documentos do PCB não existem registros de adesão ao movimento, há relatos de lideranças queremistas que atestam a presença dos comunistas entre elas. Como destaca Lucília de Almeida Neves Delgado:

\footnotetext{
A análise que desenvolvemos é a de que o Movimento Queremista e o Partido Trabalhista Brasileiro tiveram uma relação quase que umbilical. No entanto, outras forças, além das trabalhistas, também estiveram presentes na articulação do queremismo. [...] Os comunistas destacaram-se por uma atuação marcante no seio do movimento queremista. A presença de militantes do PCB nesse movimento chegou, inclusive, a assustar setores sociais e partidos políticos mais conservadores (2011, p. 53).
}

Corroboram com essa tese as declarações de diferentes personalidades políticas da época, como Tancredo Neves e Segadas Viana, presentes na já clássica obra PTB: do Getulismo ao Reformismo (1945-1964), também da historiadora. Na mesma linha escreveu Moisés Vinhas, em seu O Partidão: a luta por um partido de massas (1922-1974), ao afirmar que "os comunistas apoiaram decididamente Getúlio Vargas e saíram às ruas para lutar pela 'Constituinte com Getúlio' ao lado dos queremistas" (VINHAS, 1982, p. 86). Essa constatação, porém, não deve servir para relativizar o engajamento do PCB nos esforços em favor da pronta democratização do país. A tática de "Constituinte com Getúlio" era, para a 
maioria dos comunistas, plenamente conciliável com a defesa da mais ampla democratização política.

Além disso, o queremismo expressou uma cultura política popular e a manifestação de uma identidade coletiva dos trabalhadores, resultado de experiências vividas e partilhadas entre eles. A presença de indivíduos originários das classes populares engajados no movimento queremista expressava a vinculação com Vargas de setores populares que os comunistas buscavam representar. $\mathrm{O}$ fato de os trabalhadores terem tomado as ruas por reivindicações políticas, - e não econômicas - sintetizadas na palavra de ordem "queremos Getúlio", atuou fortemente para atrair os comunistas ao movimento (FERREIRA, 2010, p. 19). Ao contrário de um partido surdo, confinado na realidade paralela do um leninismo estéril, o PCB parecia estar bastante conectado com os sentimentos populares.

Ao mesmo tempo, a iminente legalização do partido cobrava novas bases organizativas. Além da participação no movimento queremista, o PCB também organizava a luta sindical de forma paralela à estrutura oficial sustentada pelo Ministério do Trabalho. Com isso, estabelece o Movimento Unificado dos Trabalhadores (MUT), embrião para uma Central de Trabalhadores Brasileiros, que atuava como uma espécie de intersindical e cujo objetivo era a transformação da luta corporativa em luta política geral. A ampliação das células do partido dá origem aos "Comitês Populares" ou "Comitês Democráticos", organizados por bairros com o objetivo de lutar pela ampliação da democracia, contra a carestia e pela ampliação de direitos (SEGATTO, 1989, p. 59). Diante das novas necessidades organizativas, Prestes admitia que:

[e]m vez de um pequeno partido ilegal que fazia agitação e propagava a ideia geral do comunismo e do marxismo, precisamos agora de um grande partido realmente ligado à classe operária e às forças decisivas de nosso povo (CARONE, 1982, p. 42).

Num cenário de profundas transformações e incertezas, o PCB sentia-se cada vez mais preparado para a estreia na vida pública do país.

\subsection{O PCB e as eleições de 1945}

No dia vinte e nove de outubro de 1945, resultado da crescente polarização entre Vargas e o movimento queremista, de um lado, e os setores golpistas representados pela UDN, de outro, o Estado Novo chegara ao fim, graças a uma ação liderada pelo General Góis Monteiro, que forçou a renúncia do presidente. Sucederam-se alguns dias de incerteza nos 
quais a violência contra o PCB foi retomada. As sedes do partido foram invadidas e saqueadas, e alguns de seus dirigentes perseguidos e presos (PRESTES, 2011, p. 77). A situação, porém, não redundou numa derrota do processo de democratização, e uma fórmula híbrida acabou imperando. Nem o PCB conseguia o adiamento das eleições presidenciais para depois da Assembleia Constituinte, nem os setores conservadores conseguiam frear o processo de democratização (Ibid., p. 79). Neste contexto de impasse, no dia doze de novembro de 1945, José Linhares, presidente interino, convocou as eleições para a Assembleia Constituinte e para a Presidência da República para o dia dois de dezembro do mesmo ano, apenas vinte dias depois.

$\mathrm{O} \mathrm{PCB}$, mesmo perseguido nos dias que se seguiram ao golpe de vinte e nove de outubro, já havia solicitado seu registro junto à justiça eleitoral, no dia três de setembro. $\mathrm{Na}$ ocasião apresentara um programa enxuto, de apenas duas páginas, resumindo de forma genérica as posições do partido. No dia dez de dezembro, o PCB conquistou seu registro definitivo. É curioso notarmos a pequena batalha jurídica que o partido teve de enfrentar no decorrer do processo de registro junto ao Tribunal Superior Eleitoral (TSE). Questionado pelo relator do processo, Ministro Sampaio Dória, sobre uma série de questões presentes em seu programa, o PCB teve de explicar sua concepção de reforma agrária, de "união nacional", de socialização dos meios de produção e até sua associação ao marxismo-leninismo. Em suas repostas à diligência do TSE, o partido afastou-se completamente das concepções historicamente atribuídas aos comunistas. Sobre a proposta de reforma agrária, a resposta dos comunistas afirmava que "a questão das terras próximas às grandes cidades não tange com qualquer alteração no sistema capitalista, mas deve ser enfrentada por um governo democrático de base capitalista". Em relação à "união nacional”, afirma o PCB, que esta "não seria, pois, qualquer forma de ditadura, inclusive, é óbvio, a ditadura do proletariado". Sobre a socialização dos meios de produção, o partido afirmava que "o problema econômico imediato do Brasil ainda é o fortalecimento do capitalismo nacional, pois o proletariado sofre mais da debilidade do capitalismo do que do próprio capitalismo". Por fim, abjurando suas origens, o partido afirmava ainda, em relação à sua denominação, que "no programa do Partido Comunista do Brasil não se incluem os princípios marxistas-leninistas nem quaisquer outros princípios filosóficos” (BRASIL, 1945).

Evidentemente, a análise amiúde da batalha jurídica que levou à concessão do registro definitivo do PCB nos meses de setembro e outubro de 1945 não é objeto deste trabalho. Contudo, sua menção serve para ilustrar a obsessão do PCB em viabilizar sua entrada no sistema partidário que se estruturava, participando, assim, do novo ordenamento político- 
institucional que nascia, mesmo que tivesse de, ao menos formalmente, abrandar seu discurso e adaptar seus objetivos históricos à realidade dos anos de 1940.

O processo eleitoral de 1945 marca não apenas uma saída para a crise política que caracterizou os últimos meses de Estado Novo, ele também inicia nova fase no longo processo de modernização conservadora ${ }^{41}$ iniciado com a ascensão de Getúlio Vargas ao poder em 1930. Efetivamente, a eleição de 1945 representa a primeira experiência democrática do Brasil, considerando que, como lembra Fernando Limongi, a realização de eleições, por si só, não é condição suficiente para qualificar um regime como democrático (LIMONGI, 2012, p. 37). Conforme segue:

\begin{abstract}
Eleições não eram uma novidade na história política do Brasil, afinal, direta ou indiretamente, governantes foram eleitos por mais de cem anos, de 1822 até 1930. Ainda assim, há uma ruptura em 1945: as eleições passam a ser competitivas. Há uma mudança na natureza do processo eleitoral; o governo perde o controle que sempre tivera sobre o processo eleitoral (Ibid., p. 38).
\end{abstract}

As eleições de 1945 foram regulamentadas inteiramente pelo Decreto-Lei $n^{\circ} 7.856$, que estabeleceu parâmetros para o registro dos partidos e as condições para realização das eleições. As principais eram a organização partidária em bases nacionais, por meio de subvenções de no mínimo 10 mil eleitores em cinco unidades da federação; o voto obrigatório, universal, secreto e restrito aos indivíduos adultos e maiores de 18 anos alfabetizados; a adoção de duas fórmulas eleitorais: majoritária - para as eleições de prefeito, governador, senador e presidente da República - e proporcional - para as Câmaras Municipais, Assembleias Legislativas e Câmara Federal, dentre outras (GAMA NETO, 1995, p. 45). Embora o anúncio das eleições presidenciais já houvesse sido feito em fevereiro por Vargas, a definição da convocação da Assembleia Constituinte só foi tomada após a renúncia do presidente com o golpe de vinte e nove de outubro. É provável, portanto, que os partidos tenham montado suas estratégias em pouquíssimo tempo, de acordo com as possibilidades eleitorais de cada um. No caso dos comunistas, a eleição à Assembleia Constituinte foi definida como prioridade máxima em relação à eleição presidencial. Os maiores partidos, no entanto, fizeram aposta inversa, o que transformou as eleições à Constituinte e à Presidência da República em processos muito distintos entre si.

\footnotetext{
${ }^{41} \mathrm{O}$ termo modernização conservadora foi cunhado primeiramente por Moore Júnior (1975) para analisar as revoluções burguesas, que aconteceram na Alemanha e no Japão na passagem das economias pré-industriais para as economias capitalistas e industriais. Neste sentido, o eixo central do processo desencadeado pela modernização conservadora é entender como o pacto político tecido entre as elites dominantes condicionou o desenvolvimento capitalista nestes países, conduzindo-os para regimes políticos autocráticos e totalitários (MOORE JÚNIOR, 1975, p. 503).
} 
Candidataram-se à Presidência da República pela UDN o Brigadeiro Eduardo Gomes, herói da revolta do Forte de Copacabana; e pelo PSD o General Eurico Gaspar Dutra, Ministro da Guerra no período de Getúlio Vargas, candidato então apoiado pelo presidente e seu partido, o PTB. O inexpressivo Partido Agrário Nacional apresentou a candidatura do cafeicultor Mário Rolim Teles, e o PCB apoiou o engenheiro Yeddo Fiúza, ex-prefeito de Petrópolis.

O PCB já estava em campanha pelo país quando escolheu seu candidato a presidente. Em um comício no Largo do Machado, no Rio de Janeiro, em doze de novembro de 1945, apenas vinte dias antes das eleições, Maurício Grabois, candidato comunista à Assembleia Constituinte, tivera de explicar o perfil da candidatura a Presidente da República sem, no entanto, mencionar nomes. Segundo ele, considerando o "desinteresse popular para com as duas atuais candidaturas, de maneira que o PCB resolveu apoiar um terceiro candidato democrata, patriota, capaz de conduzir o Brasil para a necessária união nacional" (OLIVEIRA, 2012, p. 160). Todavia, o líder comunista não disse em momento algum quem seria esse "democrata".

O partido, internamente, já havia decidido que a prioridade seria a disputa de cadeiras à Assembleia Constituinte e, por isso, Luís Carlos Prestes seria ao mesmo tempo candidato ao Senado e a Deputado Federal por vários estados (o que era permitido na legislação da época). $\mathrm{O}$ candidato à Presidência da República pelo $\mathrm{PCB}$, portanto, deveria ter um perfil que expressasse a política da "união nacional". Devido a isso, o partido buscava fora dos seus quadros um nome mais amplo. Os possíveis candidatos que, segundo o Diário Carioca, foram cogitados, confirmaram essa tese: Luiz Frederico Carpenter, professor de Direito da Universidade do Brasil; Prestes Maia, ex-prefeito de São Paulo; Antônio Prado Júnior, exprefeito do Distrito Federal; Abraão Ribeiro, interventor da cidade de São Paulo; e Yeddo Fiúza, ex-prefeito de Petrópolis e ex-diretor do Departamento Nacional de Estradas de Rodagem - DNER (OLIVEIRA, 2012, p. 162). Apesar de não ter passagem pelo partido, Fiúza foi apresentado pela imprensa comunista como um dedicado militante antifascista e um administrador exemplar, poucos dias depois.

Isso, entretanto, não poupou Fiúza de ataques ferozes vindos de muitas direções. Os mais duros foram proferidos por Carlos Lacerda, que acusou o engenheiro de corrupto, integralista e de fazer-se de pobre mesmo tendo patrimônio muito acima da média (Ibid., p. 172-174). Grupos anticomunistas também trabalharam incessantemente contra o candidato do PCB, especialmente a Liga Eleitoral Católica, entidade criada em 1932 para "orientar" os eleitores católicos a cada pleito (SILVA, 1974, p. 88). 
A despeito de ser pouco conhecido, do escasso tempo disponível para a campanha, dos ataques lançados pelos inimigos do $\mathrm{PCB}$ e da prioridade do partido em relação à Assembleia Constituinte, pode-se dizer que a campanha de Yeddo Fiúza foi muito bem-sucedida: o engenheiro alcançou 569.818 votos $(9,71 \%$ do total). Atrás dele, o candidato do pequeno PAN, Mário Rolim Telles, fez pouco mais de 10 mil votos. $\mathrm{O}$ candidato eleito, com o apoio de Vargas, do PSD e do PTB, foi o General Eurico Gaspar Dutra, com 3.251.507 votos (55,39\% do total), enquanto o candidato apoiado pela UDN, Brigadeiro Eduardo Gomes, alcançou 2.039.341 (34,74\% do total) (NETTO, 1986, p. 101).

O desempenho surpreendente de Yeddo Fiúza repetia o bom resultado do PCB na disputa à Assembleia Constituinte: o partido alcançara a eleição de 14 deputados federais e um senador, Luís Carlos Prestes. O resultado atestava o crescimento do PCB que, gozando da boa reputação entre os setores populares, crescia rapidamente desde meados de 1945. Para termos uma ideia de sua influência, basta notar que o jornal Tribuna Popular, editado pela seção carioca do partido, tinha uma tiragem de 25 mil exemplares diários, equivalente às edições de $O$ Globo e outros jornais comerciais (GORENDER, 2005, p. 168). No auge de seu prestígio, após a libertação de Prestes, o partido alcançou a expressiva marca de 200 mil filiados, e tinha entre seus quadros artistas e intelectuais como Cândido Portinari, Di Cavalcanti, Lazar Segall, Jorge Amado, Graciliano Ramos, Oscar Niemeyer, Carlos Drummond de Andrade, Oswald de Andrade, dentre outros (KONDER, 2004, p. 67). Grandes comícios foram realizados ao longo da campanha e um avião chegou a ser fretado para que Prestes pudesse percorrer o país na curta campanha eleitoral. Nesses comícios, Prestes reafirmava sua defesa em favor da "ordem e da tranquilidade", condenava os "golpes salvadores" e se referia com respeito aos "patrões progressistas", que seriam aliados do “desenvolvimento pacífico" do Brasil (PRESTES, 2010, p. 83). Em Recife, o Secretário-Geral do PCB chegou a afirmar que "é preferível [...] apertar a barriga, passar fome, do que fazer greves e criar agitações" (Ibid., p. 87).

A campanha dos comunistas, no entanto, não se preocupava apenas com o conteúdo da política definida pelo Comitê Central. Também a forma era um aspecto que exigia a atenção do partido. Numa carta circular emitida pelo Secretariado Nacional a todos os Comitês Estaduais do PCB, acerca da mobilização para a campanha eleitoral de dezembro de 1945 , com uma série de diretrizes sobre os métodos de propaganda a serem utilizados, pode-se conhecer um pouco das estratégias de marketing que os comunistas buscavam empregar. Segundo esta circular, a campanha eleitoral deveria começar a utilizar métodos mais modernos, pois as novas condições de liberdade e legalidade políticas permitiriam que a 
propaganda se tornasse mais "agradável e atraente" (MONTEIRO, 2012, p. 96). De acordo com as sugestões desta carta: “[...] 'Shows', 'scketch' [sketch], números de dança e de músicas podem iniciar os comícios. Artistas de renome que são membros do partido ou estão de acordo com sua orientação, darão bastante relevo, etc." ${ }^{\text {"42 }}$. Além disso, apesar de advogar a ideia de que o mandato pertencia ao partido - chegando a exigir a renúncia do constituinte Mário Scott, para que Milton Caires de Brito assumisse sua vaga pelo estado de São Paulo, logo no início dos trabalhos da Constituinte - o PCB usava a biografia de seus parlamentares a seu favor (SANTANA, 2001, p. 49). A carta circular mencionada anteriormente recomendava um trato especial à trajetória pessoal do candidato, já que o partido reconhecia que os eleitores votavam em pessoas e não em partidos. Por essa razão, era sugerido dar amplo destaque à biografia dos candidatos “[...] mostrando não só os aspectos mais destacados de sua vida política, como também os lados comoventes de sua vida particular, como chefe de família e amigo de seus companheiros"43. As biografias deveriam sempre vir acompanhadas de fotografias "artisticamente feitas" em que o candidato era apresentado em sua atividade profissional (MONTEIRO, 2012, p. 97).

Mas se a propaganda teve um papel importante na estratégia dos comunistas, mais decisiva ainda foi a inserção dos quadros do partido na reorganização do movimento dos trabalhadores organizados. Seu esforço na construção de órgãos intersindicais, especialmente o MUT (Movimento Unificador dos Trabalhadores), manteve um vínculo estreito com as principais lutas em curso. Embora nem sempre favorável às greves e manifestações, o partido não perdia o vínculo com o movimento dos trabalhadores. Em São Paulo, a força dos comunistas concentrava-se em Santos e na capital. Na empresa Nitroquímica, em São Miguel Paulista, dos seis mil trabalhadores da fábrica, mil se filiaram ao PCB. No Distrito Federal, a força do partido concentrava-se nos metalúrgicos, têxteis, docas, transportes marítimos, estendendo-se ainda aos servidores públicos, estudantes, organizações de bairros e favelas, que tinham sua agenda própria. No Rio Grande do Sul, a influência comunista era forte entre os metalúrgicos e demais áreas de grande industrialização; e, em Pernambuco, o partido tinha influência sobre vários setores e elegeria o primeiro prefeito comunista do país, em Jaboatão dos Guararapes, região metropolitana em Recife, no ano de 1947 (VINHAS, 1982, p. 89). Ao contrário das teses que advogam em favor da ideia de uma "burocratização" do PCB em relação às suas bases operárias, Marco Aurélio Santana observa que, no período anterior ao golpe de 1964, este partido esteve efetivamente inserido no movimento operário e sindical

\footnotetext{
${ }^{42}$ Cf. Arquivo Público do Paraná. DOPS, 1945a, fl. 264.

${ }^{43}$ Cf. Ibid., fl. 264.
} 
(SANTANA, 2001, p. 32). Por isso, embora fosse surpreendente para um partido recém-saído da clandestinidade, seu bom desempenho pode ser plenamente explicado por esse forte enraizamento popular.

O resultado da participação comunista nas eleições foi muito positivo para o PCB. Apesar de uma bancada modesta, o partido alcançou 8,6\% dos votos válidos, consolidando-se como a quarta maior bancada (só atrás de PSD, UDN e PTB). A maioria dos votos do PCB veio dos centros urbanos, especialmente no Sudeste (Rio de Janeiro e São Paulo), onde havia um maior número de operários e mais tradição em termos de organização política. Mas o partido elegeu parlamentares também no Rio Grande do Sul, Bahia e Pernambuco, centros operários regionais de importância. Não há estudos que explorem a fundo a relação entre o bom resultado eleitoral do PCB e as movimentações táticas que o aproximaram do varguismo, sobretudo enquanto vigorou o movimento queremistas, mas não devemos considerar pura coincidência que o partido tenha concentrado seus melhores resultados nas regiões industriais, justamente nos lugares onde o "queremismo" demonstrou mais força no período imediatamente anterior às eleições.

O PCB poderia ter tido um desempenho ainda melhor, não fosse a fórmula aplicada pela legislação vigente que, conforme destaca Daniel Aarão Reis Filho, "atribuía valor desigual aos votos, segundo os estados e municípios do país, privilegiando-se áreas rurais em detrimento dos centros urbanos" - segundo ele, mesmo tendo alcançado 8,6\% dos votos, os comunistas elegeram apenas 4,7\% dos constituintes (REIS FILHO, 2014, p. 234). Considerando-se este e outros elementos, como o nível de mobilização, o engajamento de personalidades na campanha dos comunistas e o fortalecimento das instâncias de base em diversos estados, podemos compreender o porquê de aquela ser considerada até hoje a mais vitoriosa das campanhas que o PCB já enfrentou.

Apenas a título de comparação, quando foram eleitos os deputados à Assembleia Nacional Constituinte, em novembro de 1986, quatro décadas depois, o desempenho dos comunistas foi infinitamente mais modesto. Separados em duas agremiações desde 1962 PCB e PCdoB - os comunistas elegeram apenas três deputados constituintes cada um (num total de 487). Esses seis deputados somados representavam apenas 1,24\% do total de constituintes eleitos. Entre os partidos de esquerda que disputaram as eleições à Constituinte em 1986 (PT, PSB e PDT) apenas o partido de Leonel Brizola alcançou percentual equivalente àquele conquistado pelo PCB em 1945 (4,93\%), enquanto o PT conquistou 3,28\% e o PSB apenas 0,2\% das cadeiras na Constituinte (BRASIL, 1987, p. 16). 
Tal comparação, embora ressalvadas as realidades históricas absolutamente distintas que cercam as Constituintes de 1946 e 1987/1988, serve apenas para ilustrar o excelente resultado alcançado pelos comunistas nos anos de 1940 e a dimensão dessa vitória para os atores políticos da época.

\subsection{A bancada do PCB na Assembleia Constituinte: uma introdução}

A Assembleia Constituinte era composta por 297 deputados e 41 senadores, totalizando 338 Deputados Constituintes ${ }^{44}$. Na tabela abaixo, podemos ter um panorama dos deputados e senadores eleitos por cada partido, incluindo suplentes que tomaram posse.

Conforme segue:

\begin{tabular}{|c|c|c|c|}
\hline \multicolumn{4}{|c|}{ NÚMERO DE CONSTITUINTES ELEITOS POR PARTIDO $^{45}$} \\
\hline Partido & Senadores & Deputados & Total \\
\hline PSD & $26(63,5 \%)$ & $158(53,5 \%)$ & $185(54,7 \%)$ \\
\hline UDN & $11(26,9 \%)$ & $81(27 \%)$ & $89(26,9 \%)$ \\
\hline PTB & $01(2,4 \%)$ & $22(7,4 \%)$ & $23(6,8 \%)$ \\
\hline PCB & $01(2,4 \%)$ & $15(5,1 \%)$ & $16(4,7 \%)$ \\
\hline PR & $01(2,4 \%)$ & $11(3,7 \%)$ & $12(3,7 \%)$ \\
\hline PSP & $01(2,4 \%)$ & $07(2,3 \%)$ & $08(2,4 \%)$ \\
\hline PDC & - & $02(0,7 \%)$ & $02(0,6 \%)$ \\
\hline PL & - & $01(0,3 \%)$ & $01(0,3 \%)$ \\
\hline TOTAL & 41 & 297 & 338 \\
\hline
\end{tabular}

Fonte: BRAGA, S. S. Quem foi quem na Assembleia Nacional Constituinte de 1946.

Além do PCB, outros nove partidos elegeram representantes, sendo que os comunistas tinham a quarta maior representação. Cabe destacar que o PCB teve uma campanha muito abrangente, lançando candidatos em todos os estados (tal feito é igualado apenas pelo PSD e

\footnotetext{
${ }^{44}$ Em variadas fontes, afirma-se que a Assembleia Constituinte seria formada por 328 membros. Porém, os dados oficiais compilados no estudo de Sérgio Soares Braga (1998), confirmam o número de 338 parlamentares.

${ }^{45}$ BRAGA, S. S. Quem foi quem na Assembleia Nacional Constituinte de 1946. Um perfil socioeconômico e regional da Constituinte de 1946. Brasília: Câmara dos Deputados, 1998, p. 44. Entre os 81 deputados eleitos pela UDN, dois deles pertenciam à Esquerda Democrática, que em 1948 originaria o Partido Socialista Brasileiro (PSB). Além disso, cabe registrar que Partido Social Progressista organizou-se durante o processo constituinte pela união do Partido Popular Sindicalista (PPS), do Partido Republicano Progressista (PRP) e do Partido Agrário Nacional (PAN).
} 
pela UDN) e elegendo deputados em seis unidades da Federação (BA, PE, DF, RJ, SP e RS), a maior parte concentrada na região sudeste - só em São Paulo foram quatro deputados. Além disso, 12 dos 15 eleitos pelo PCB haviam sido presos políticos durante o Estado Novo. O partido contava, ainda, com a bancada mais jovem (a maioria tinha menos de 40 anos) e com o menor nível de instrução (a maioria não possuía curso universitário). Embora tenha tido seu melhor desempenho eleitoral no Distrito Federal (alcançando 21\%), também obteve um resultado significativo no Nordeste, onde elegeu três deputados $(14,3 \%)$ da bancada pernambucana. A maioria da bancada comunista, aliás, era de origem nordestina: nove deputados (BRAGA, 1998, p. 79).

Para termos um panorama do perfil da bancada comunista em relação às demais, tomemos como referência a bancada do PSD. Entre os senadores e deputados eleitos por aquele partido, havia 10 banqueiros, 19 industriários, 43 proprietários de terras, 28 advogados, além de vários médicos, engenheiros, jornalistas e professores universitários, dentre outras profissões. A bancada do PCB, por sua vez, era forma por dois jornalistas (Carlos Marighella e Maurício Grabois), um escritor (Jorge Amado), um contador (João Amazonas), um engenheiro militar (Prestes), dois médicos (Milton Caires de Brito e Alcedo Coutinho), um camponês (Gregório Bezerra) e sete operários (Batista Neto, Agostinho de Oliveira, Abílio Fernandes, Alcides Sabença, José Crispim, Osvaldo Pacheco e Claudino José da Silva). Portanto, a bancada comunista se diferia das demais não apenas por suas propostas, mas também pela origem social de muitos de seus membros (Ibid., p. 146).

A bancada eleita pelo PCB era formada por quadros experientes, muitos deles vinculados ao trabalho no movimento sindical ou na organização política do partido. Não dispomos de dados que possam atestar que a direção do PCB tenha estimulado alguma política que privilegiasse os nomes eleitos (a não ser Prestes, candidato prioritário do partido ao Senado). Porém, a eleição, tanto de dirigentes políticos experimentados quanto de uma expressiva representação de líderes operários, demonstra que o PCB soube tirar proveito do trabalho político desenvolvido junto aos trabalhadores e do prestígio de que gozavam alguns de seus dirigentes.

A bancada paulista do PCB era composta por quatro deputados, todos eles originários de estados da Região Norte e Nordeste do país: Milton Caires de Brito (eleito com 10.595 votos), destacado militante comunista na Bahia e um dos principais responsáveis pela reorganização do PCB após a Conferência da Mantiqueira; Jorge Amado (eleito com 15.315 votos), então já conhecido como um dos principais escritores do país; José Crispim (deputado comunista mais votado em todo o país, com 36.657 votos), ex-sargento do exército e ex-preso 
político; e Osvaldo Pacheco (eleito com 18.420 votos), estivador e líder sindical da cidade de Santos, (NETTO, 1986, p. 71).

A bancada do PCB da Bahia era formada por Carlos Marighela (eleito com 5.188 votos), já na época um dos mais respeitados líderes nacionais do partido. Preso pela primeira vez em 1932, retomou sua militância estudantil até ser convocado pela Direção Nacional do PCB. A partir de então atuou clandestinamente no Rio de Janeiro e em São Paulo, até ser novamente preso em 1936. Mais uma vez preso, em 1938, permaneceu no cárcere até a anistia de 1945, quando saiu da prisão para o Comitê Central do partido (BRAGA, 1998, p. 233).

A bancada pernambucana do PCB era formada por três dos quatro Constituintes eleitos pelo partido na região nordeste: Agostinho de Oliveira (eleito com 5.160 votos), antigo militante comunista e um dos mais destacados organizadores do PCB durante o Estado Novo; o médico Alcedo Coutinho (eleito com 2.917 votos), considerado o membro mais moderado da bancada comunista e com a votação mais baixa entre todos os eleitos; e Gregório Bezerra (eleito com 14.341 votos), histórico dirigente comunista, uma das principais lideranças populares pernambucanas desde os anos 1930 (Ibid., p. 515).

A bancada eleita pelo Distrito Federal (então localizado na cidade do Rio de Janeiro) foi a maior bancada do PCB em todo o país, com quatro constituintes (um senador e três deputados), de um total de 19 eleitos naquela unidade da federação. A bancada comunista no DF era composta por Luís Carlos Prestes (eleito com 157.397 votos), único senador do partido, preso político durante todo o Estado Novo (1936-1945) e principal liderança comunista nacional; Batista Neto (eleito com 14.177 votos), operário do Arsenal de Marinha e presidente do Comitê Metropolitano do MUT no Rio de Janeiro; João Amazonas (eleito com 18.379 votos), dirigente paraense que participou ativamente da reorganização do PCB após a Conferência da Mantiqueira, e foi um dos mais destacados dirigentes do MUT em todo o país, tendo sido ainda o deputado federal mais votado no Distrito Federal, com 18.379 votos; e Maurício Grabois (eleito com 15.243 votos), outro destacado dirigente e intelectual do PCB durante a clandestinidade do Estado Novo e ex-dirigente estadual do partido na Bahia (BRAGA, 1998, p. 290).

A bancada fluminense do PCB era formada pelo operário metalúrgico Alcides Sabença (eleito com 6.403 votos), fundador de vários sindicatos no Rio de Janeiro e membro da Comissão Política do partido em Volta Redonda, e por Claudino José da Silva (eleito com 11.291 votos), líder ferroviário com intensa trajetória na organização partidária após a Conferência da Mantiqueira, considerado o único constituinte negro dentre os 338 parlamentares que participaram dos trabalhos da Assembleia de 1946 (NETTO, 1986, p. 76). 
A bancada gaúcha, por fim, era composta por Abílio Fernandes (eleito com 5947 votos), operário metalúrgico e líder sindical, tendo sido presidente do sindicato dos metalúrgicos de Pelotas e Secretário-Geral da comissão política do PCB no RS, e por André Trifino Correia, ex-líder tenentista e integrante da Coluna Prestes, participou dos trabalhos constituintes por um curto período na condição de $2^{\circ}$ Suplente.

Esses deputados enfrentaram uma Assembleia Constituinte majoritariamente conservadora. Incidiam fortemente sobre ela interesses vinculados aos mais poderosos grupos econômicos nacionais e internacionais, o governo autoritário de Dutra e os limites impostos pela Constituição de 1937, então em vigor. Além disso, a composição PSD-UDN, variantes de uma oligarquia cindida, asseguraria a obstrução de quaisquer propostas mais progressistas (NETTO, 1986, p. 64).

O PCB, por sua vez, tinha dificuldades de equilibrar a proposta de "união nacional" com a realidade de um governo marcadamente autoritário e pouco aberto à influência dos comunistas. Prova disso foi a decisão do governo Dutra de decretar a ilegalidade do MUT em maio de 1946, muito embora ele tenha seguido existindo por mais alguns meses de forma clandestina. Pouco antes da posse de Dutra, o partido apontou as diretrizes para atuação de sua bancada parlamentar. Segundo destaca Anita Leocádia Prestes:

\footnotetext{
No que se refere à atuação da bancada parlamentar comunista na Constituinte, o Pleno [do Comitê Central] reafirmou os princípios incluídos no programa mínimo da União Nacional, divulgado pelo PCB em novembro de 1945, antes, portanto, das eleições de 2 de dezembro daquele ano. Entre os pontos mais importantes então aprovados deve-se destacar a defesa do direito de voto para todos os cidadãos brasileiros maiores de 18 anos, inclusive analfabetos, soldados e marinheiros. Da mesma forma, a garantia efetiva das liberdades de opinião, de consciência, de reunião, de associação, inclusive política, de manifestação e pensamento (PRESTES, 2010, p. 91).
}

Como se percebe, a plataforma da bancada de deputados à Constituinte teve como centro as tarefas de constituição de uma democracia liberal típica. Após oito anos de Ditadura, não era uma plataforma menos importante. Mas até onde poderia o PCB subordinar outras conquistas políticas e econômicas dos trabalhadores a essa tarefa?

\subsection{O PCB por dentro da ordem}

O PCB estreou na nova ordem institucional em um momento em que diversos partidos comunistas em todo o mundo viviam um vertiginoso crescimento. A política das "frentes 
populares", difundida pela Internacional Comunista como forma de combater o nazifascismo nos anos 1930, proporcionou significativas vitórias eleitorais para os comunistas no pósguerra. Na França e na Itália, por exemplo, seus respectivos partidos comunistas - PCI e PCF - tornavam-se maiores que seus concorrentes socialistas, conquistando pela primeira vez a condição de forças hegemônicas junto às classes operárias (PANDOLFI, 1995, p. 144). Nesses países, os comunistas promoveram uma política de alianças que buscava atrair para sua órbita partidos de fora do campo socialista. Na América Latina, de acordo com as leituras herdadas da Internacional Comunista acerca do estágio de desenvolvimento das forças produtivas em nosso continente, essas alianças privilegiavam a chamada "burguesia nacional" - fração supostamente progressista dos capitalistas dispostos a superar o estágio "semifeudal" de nossa formação socioeconômica. A tática de "união nacional" respondia também a essa lógica. O problema, como aponta Lúcio Flávio Rodrigues de Almeida, foi que nenhuma fração burguesa manifestou qualquer disposição de aproximar-se dos comunistas com o fim da Segunda Guerra Mundial:

\footnotetext{
Obviamente, esta era a posição da parte da burguesia mercantil-financeira, mais comprometida com o tipo de dependência em relação imperialismo, especialmente o norte-americano e que, internamente, adotava as posições mais antipopulares. Todavia, mesmo a fração industrial pouco afeita a concessões frente aos trabalhadores mobilizados e a um partido comunista que crescia exponencialmente, jogou todas as fichas na estratégia de adesão à cruzada liderada pelos Estados Unidos contra o "totalitarismo soviético" (ALMEIDA, 2003, p. 89).
}

O governo Dutra, como já demonstramos ser característico do período estudado, mantinha traços de ruptura e continuidade em relação ao governo de Vargas. Se, por um lado, desperdiçava o superávit da balança comercial acumulado por seu antecessor, exaurindo as reservas em moeda estrangeira e permitindo uma maior liberalização da economia - inclusive com estímulos à entrada de capitais estrangeiros no país; por outro, relaxava a política de crédito com vistas a retomar o investimento produtivo na indústria e incentivava medidas de planejamento com vistas a proteger a economia nacional (CHILCOTE, 1982, p. 104).

O fim da Segunda Guerra afetou a pauta de exportações e importações do Brasil. Com a volta ao mercado dos antigos fornecedores e com o início da recuperação econômica, caiu a exportação brasileira de matérias-primas e de manufaturas. Estas, que chegaram a representar $20 \%$ da pauta em 1945, caíram para 7,5\% em 1946, continuando em queda até alcançar menos de $1 \%$ em 1952. As importações enfrentavam as pressões resultantes da necessidade de reequipar a indústria e o intenso aumento dos preços internacionais (VIANA, 1990, p. 167). A 
desindustrialização se acentuou, aumentava a necessidade de investimentos externos, o que estimulou, nos anos finais do governo Dutra, a implantação interna de indústrias substitutivas de bens de consumo (sobretudo os duráveis), que ainda não eram produzidos internamente. Esta foi basicamente a fase de implantação das indústrias de aparelhos eletrodomésticos e outros artefatos de consumo durável (Ibid., p. 168).

No plano político, o Governo Dutra não mantinha tantas ambiguidades. Especialmente no que se refere às liberdades democráticas, por certo o tema mais caro na agenda política dos comunistas à época, Dutra colecionava medidas que reforçavam seu caráter fortemente conservador, governando com base em centenas de decretos-leis, enquanto era formulada a nova Constituição. Para se ter uma ideia, apenas entre fevereiro e setembro de 1946, período em que vigorou a Assembleia Constituinte, o Governo Dutra editou 1457 destes decretos-leis (REIS FILHO, 2014, p. 238). Um dos decretos mais graves, praticamente anulava o direito de greve. Em seguida viriam restrições ao direito de manifestação e de reunião. Até a metade de seu mandato como presidente, o governo de Dutra interviria em 143 sindicatos, além de fechar a Confederação dos Trabalhadores do Brasil (CTB), central sindical recém-criada pelo PCB. Após isso, Dutra rompeu relações diplomáticas com a União Soviética e pavimentou as condições para a cassação do registro do PCB.

Com o início da Constituinte, os comunistas assumiram uma posição extremamente delicada. De um lado, seguiam defendendo a política de "união nacional", mesmo tendo diante de si um governo com fortes tendências antipopulares. De outro, denunciavam a orientação conservadora que a Assembleia Constituinte tomara desde seu início, enquanto defendiam que os trabalhadores deviam se dedicar à construção da unidade nacional, da paz e da ordem social. Essa posição aparentemente contraditória não duraria muito tempo. Num informe político da Comissão Executiva ao Comitê Nacional, datada de quatro de janeiro de 1946, este organismo já assinalava não ter dúvidas "quanto ao caráter tremendamente reacionário das forças políticas agrupadas por trás da candidatura vencedora” e destacava que “o próprio candidato é perfeitamente conhecido pela sua persistente solidariedade, a mais negra reação do último decênio [...] sumamente comprometido por suas estreitas ligações pessoais com os bandos integralistas" (VINHAS, 1982, p. 120). O candidato a que o documento se refere é, logicamente, Eurico Gaspar Dutra. Já a reunião do Pleno, realizada no mesmo mês, aprovou uma caracterização mais branda do governo Dutra: "apoio franco e decidido aos seus atos democráticos e luta intransigente, se bem que pacífica, ordeira e dentro dos recursos legais, contra qualquer retrocesso reacionário" (PRESTES, 2010, p. 91). 
Acontece que, como vimos, os "atos democráticos" não eram uma característica do Governo Dutra.

No âmbito das lutas sindicais, exatamente pela caracterização que faziam, os primeiros meses de vida legal dos comunistas foram marcados por uma política dúbia. Embora impulsionasse o Movimento de Unificação dos Trabalhadores (MUT), o partido mantinha a orientação em favor da "ordem e tranquilidade". Fiel à tese da revolução democráticoburguesa, o PCB seguia apontando a necessidade de "tentar a harmonia entre operário e patrão nas relações capitalistas para melhor lutar contra o atraso, a miséria e a ignorância em que vegeta nosso povo" e "por meio da luta prática pelo rendimento maior do trabalho, será mais fácil atrair à união nacional as camadas mais progressistas da burguesia nacional" (Ibid., 102). Entretanto, ao longo do ano de 1946, a escalada repressiva por parte do Governo Dutra aumentou exponencialmente, levando o PCB ao seu maior dilema. Como pregar um clima de "união nacional" com um governo que reprime as liberdades democráticas? Como afirma Marco Aurélio Santana:

\begin{abstract}
A encruzilhada se constituía pelo fato de que o partido, devido à sua orientação política, via o espaço institucional parlamentar como centro indispensável de ação e, ao mesmo tempo, tentava vocalizar, ainda que de forma limitada, para um parlamento completamente adverso, as demandas da classe operária. Isso em uma direção. Na outra, o partido precisava, em busca de salvaguardar sua vida legal e a manutenção da democracia, voltar-se para os trabalhadores com reivindicações de cunho marcadamente político, de atenuação das demandas econômicas de classe. Mais difícil ainda era convencer sua militância disso (SANTANA, 2001, p. 50).
\end{abstract}

Independentemente da posição do PCB em relação ao Governo Dutra, a atuação da bancada comunista nunca negligenciou a luta pela ampliação das liberdades democráticas. $\mathrm{O}$ clima, no entanto, não poderia ser pior. Os comunistas eram hostilizados por todos os lados. Como destaca Daniel Aarão Reis Filho, o cerco ao PCB envolvia a polícia, o governo, as Forças Armadas, a imprensa, os partidos conservadores e até a esquerda não comunista. Cada um com suas motivações (REIS FILHO, 2014, p. 240). Os comunistas, apesar de apresentarem uma plataforma reformista bastante moderada, eram diuturnamente acusados de terem "tendências insanáveis à ditadura", de serem "agentes de Moscou" ou "autômatos a serviço do grande chefe, Stálin" (Idib., p. 236).

Ao contrário das apostas comunistas, a Assembleia Constituinte nasce profundamente conservadora. Primeiro, porque convive com um governo já instalado e cujas tendências autoritárias já assinalamos; segundo, porque tem de bater-se com uma legislação paralela e inibidora, utilizada por este mesmo governo ao longo de meses; e terceiro, pelos limites 
impostos pela utilização da Carta Magna de 1937, a "Polaca", como texto-base para os trabalhos da Assembleia Constituinte de 1946 (NETTO, 1986, p. 63). Além disso, há fortes indícios de que grupos econômicos estrangeiros tenham tentado interferir no processo legislativo com vistas a preservar seus interesses e impedir restrições a seus negócios no país. Essa luta em torno dos destinos da Assembleia Constituinte, contudo, não se dava sem a influência de forças da sociedade civil. Como destaca Giovanetti Netto:

O Estado resiste a todas as investidas contra seu poder, valendo-se da cooptação, quando possível, e da violência, quando necessário, renovando os seus quadros e mantendo-se entre tensões e conflitos que vão determinar o grau de articulação com setores da sociedade civil, bem como o seu afastamento ou aproximação com relação aos mesmos. Por outro lado, a sociedade civil busca de alguma forma se fortalecer em meio aos ruídos da democratização (NETTO, 1986, p. 28).

Foi neste cenário sobremaneira hostil e limitado que os comunistas atuaram. A política de "união nacional" ainda vigorava, mas a promessa de uma coexistência pacífica entre o campo socialista - liderada pela URSS - e as democracias ocidentais, com as quais os soviéticos estiveram aliados para derrotar a ameaça nazifascista, mostrava-se cada vez mais improvável. O cenário apontava, pelo contrário, para uma retomada do acirramento políticoideológico, com uma mudança acelerada na política externa dos Estados Unidos e da Inglaterra. Neste processo de recrudescimento, a diplomacia brasileira não tardou a alinhar-se às novas tendências inauguradas pelas potências ocidentais. Em pouco tempo a imprensa, as Forças Armadas, a Igreja Católica e todas as demais instituições do establishment aderiram ao discurso da luta da liberdade e da democracia contra o totalitarismo soviético.

\subsection{A luta por uma Constituinte democrática}

Cientes de que o cerco se fechava, os comunistas deram o combate para assegurar uma Constituinte, quanto mais democrática possível. Eles sabiam que, além de lutar para que medidas democratizantes fossem incluídas na nova Carta Constitucional, era preciso garantir que a própria Assembleia permitisse algum nível de influência de posições mais progressistas.

A primeira batalha do partido foi para impedir que um membro de outro poder - o ministro do Supremo Tribunal Federal, Valdemar Falcão - participasse da mesa diretora da Assembleia Constituinte durante a fase preparatória dos trabalhos. Já na sessão inaugural de $1^{\text {o }}$ de fevereiro de 1946, Maurício Grabois pediu a palavra em nome da bancada comunista e, logo após a instalação da reunião, formulou uma questão de ordem para questionar a condução da sessão pelo ministro Falcão, que também era presidente do Tribunal Superior 
Eleitoral, reivindicando que os trabalhos da Assembleia fossem conduzidos por um parlamentar. Em seguida, Grabois apresentou um projeto de Normas Regimentais para os trabalhos da Constituinte, assinado por onze dos quinze deputados constituintes do partido, além de Prestes (NETTO, 1986, p. 117). Essa proposição foi apoiada por Café Filho (PSP/RN), então futuro vice-presidente de Vargas. Na sessão seguinte, Carlos Marighella seria ainda mais duro, ao afirmar que "[...] o presidente do Tribunal Superior Eleitoral está investido de poderes por um decreto-lei baixado pelo governo, decreto que se apoia na Carta Constitucional de 10 de novembro de 1937, carta fascista, caducam renegada por seus próprios autores” (Ibid., p. 118). Ato contínuo, João Amazonas apelaria para que o ministro Falcão se retirasse do Palácio Tiradentes, em respeito à soberania da Assembleia Constituinte.

O tema ganhou repercussão nos jornais. Na edição do dia dois de fevereiro de 1946, o jornal Folha da Manhã descrevia, assim, a proposição da bancada comunista:

Os Comunistas, como tanta gente previa, quiseram tomar conta da assembleia por
um golpe felizmente mal engendrado. Aberto os trabalhos, na conformidade das
disposições legais existentes, pretenderam mudar da presidência do T.E.S [sic], o
Ministro Valdemar Falcão, a quem a lei conferia poderes para examinar os diplomas
de Deputados e Senadores, e o mais, até a eleição da Mesa da Assembleia. Para isso,
pediram a palavra, e uns sobre os outros, impugnaram a presença daquele
magistrado na mesa da Assembleia, chegando a chamá-lo de "corpo estranho" e a
aconselhar a retirada do recinto, se não fossem atendidos. [...] A maioria, que era
toda a representação que se achava no recinto da Câmara dos Deputados, com
exceção dos dezessete comunistas, assistiu às tentativas de perturbação da boa
marcha dos trabalhos, tranquila e confiante." (1946, p. 12).

O tema foi retomado nas sessões seguintes. Ao mesmo tempo, os comunistas questionaram a validade da Constituição de 1937 durante os trabalhos da Assembleia. Num clima de euforia democrática, a questão ganhou grande relevância junto à opinião pública. Os parlamentares da UDN se uniram aos comunistas contra os parlamentares do PTB e do PSD, numa até então inusitada aliança contra os resquícios do Estado Novo na Assembleia Constituinte. O deputado Otávio Mangabeira (UDN/BA) propôs a nomeação imediata de uma comissão de três membros para redigir um regimento interno, invalidando imediatamente os efeitos da "Polaca" sobre a Assembleia Constituinte. Buscando transformar a redação da nova Carta em um tribunal dos crimes cometidos pelo Estado Novo, a UDN apoiava qualquer iniciativa no sentido de demonstrar a natureza autoritária e ditatorial do regime liderado por Getúlio Vargas, chegando a lamentar que "a nova democracia brasileira se tivesse deparado na triste contingência de ser gerada, por assim dizer, do ventre do Estado Novo" (NETTO, 1986, p. 106). Ainda na primeira sessão preparatória, os comunistas usariam a palavra para atacar o 
Ministro do Trabalho, Indústria e Comércio, Otacílio Negrão de Lima, membro do PTB. Numa manifestação sobre a situação econômica dos trabalhadores brasileiro, o ministro afirmara que “[...] não se justifica no momento, o recurso extremo das greves, principalmente intempestivas, criando dificuldades ao governo democrático que se inicia e perturbando a vida pacífica da Nação” (Brasil, 1946, vol. I, p. 11). Em resposta, Carlos Marighella manifestara seu repúdio às declarações do ministro e destacou a posição dos comunistas "em favor dos atos democráticos do governo" e em oposição às medidas que pudessem representar retrocessos nas conquistas dos últimos meses. Chama a atenção o fato de Marighella, logo na primeira sessão, ter destacado minuciosamente aqueles acontecimentos que afastavam o PCB do apoio franco e aberto a Dutra: tal como sua participação no golpe que depôs Vargas em 10 de novembro de 1945 e o apoio dos integralistas infiltrados no Partido da Representação Popular (PRP), recebido por Dutra sem qualquer pudor. Mais que afirmar uma posição de independência, os comunistas buscavam fazer uma divisão clara de campos no interior da Constituinte.

A repercussão dos primeiros combates travados pelo PCB na Assembleia Constituinte não poderia ter sido pior. Como demonstra Evaristo Giovanetti Netto, praticamente toda a grande imprensa tratou de dar à atuação dos comunistas um caráter incompatível com a existência de instituições democráticas. Editoriais dos principais jornais se manifestaram contra o partido, como o Estado de São Paulo, que afirmou à época: "não há dúvida que o Partido Comunista representa, hoje, em todo o mundo, um elemento de perturbação da vida coletiva e que persiste em seu programa de revolução universal” (NETTO, 1986, p. 97). Além da imprensa, dezenas de deputados se sucediam nas tribunas do Palácio Tiradentes, afirmando sua inconformidade com a presença dos comunistas na Assembleia Constituinte. Em sucessivos discursos, os parlamentares reafirmaram mais ou menos os mesmos argumentos, a saber: a) a incompatibilidade do comunismo com a democracia e a liberdade (portanto, com sua presença numa instituição democrática como a Assembleia Constituinte); b) o exotismo da proposta comunista, totalmente descabida diante da índole pacífica e cristã do povo brasileiro; c) o fato de que consideravam o comunismo um efeito das injustiças sociais, logo, podendo ser combatido se fossem erradicadas as causas que o alimentavam; d) o tratamento para com os comunistas como inimigos da pátria, agentes de interesses estrangeiros e representantes de uma visão de mundo absolutamente minoritária na sociedade (Ibid., p. 98).

O Regimento Interno apresentado na sexta sessão ordinária da Assembleia Constituinte, previa que durante as sessões os constituintes não poderiam tratar de outros temas que não tivessem relação direta com as matérias constitucionais em discussão pela 
Assembleia, autolimitando seus poderes e sujeitando o legislativo a toda sorte de interferências. Além disso, foram apresentadas várias emendas com a finalidade de restringir o número de apartes, questões de ordem e discursos de um mesmo partido por sessão, haja vista a ativa participação dos comunistas durante os trabalhos da Constituinte. A ideia era impedir que os comunistas utilizassem a tribuna como espaço de "agitação política". Como se vê, a convivência com os demais partidos não era nada fácil, o que aumentava a sensação de isolamento no interior da Constituinte.

\subsection{As propostas do PCB}

Em 15 de março de 1946, menos de 45 dias após a instalação da Assembleia Constituinte, a Comissão de Constituição, presidida pelo senador Nereu Ramos (PSD/SC), reuniu-se para preparar o texto inicial que seria discutido pelos constituintes. Dividida em grupos temáticos, a Comissão tomou como base a Constituição de 1934, sob protesto dos comunistas. O relator do projeto era o deputado Cirilo Júnior (PSD/SP). Foram mais de dois meses até que o anteprojeto fosse apresentado ao plenário da Assembleia Constituinte, o que só ocorreu em 27 de maio. Ao todo, foram apresentadas mais de 4.000 mil emendas ao texto, sendo 180 delas oriundas da bancada comunista (FRANCO, 1978, p. 110). A versão final era conservadora e pouco inovava em relação à carta de 1934. Como afirma Giovanetti Netto:

[...] Se, de um lado, o projeto não era capaz suscetibilizar os setores populares, por outro, parecia assegurar aos donos do poder uma transição segura para o novo regime e um sono tranquilo, posto que intocados estariam seus interesses fundamentais. A Constituinte, a julgar pelo projeto que doravante nortearia os debates, não viera para mudar e sim para legitimar; a Constituinte não viera para afirmar o novo e sim para consagrar o estabelecido; não viera para reformular as estruturas do país, mas sim para consolidá-las. A Constituinte recuou diante dos desafios do pós-guerra, mostrou-se temerosa ante as novas experiências, apelou para a tradição e apegou-se aos valores já experimentados e adquiridos (NETTO, 1986, p. 121).

Como notamos, o resultado final do texto elaborado pela Comissão estava muito aquém das expectativas daqueles que acreditavam ser possível um anteprojeto que contemplasse os anseios históricos das classes populares. Ilusão que fora alimentada pelo PCB, graças ao excessivo otimismo dos comunistas em relação às perspectivas do pós-guerra. Aliás, otimismo que pode ser notado mesmo na passagem acima: se a Constituinte era composta majoritariamente de indivíduos ligados às classes dominantes e às velhas oligarquias, por que esperar que o resultado pudesse ser diferente? Como supor, como sugere 
Giovanetti Netto, que a Constituinte pudesse "afirmar o novo" ao invés de "consagrar o estabelecido"?

Os limites e fragilidades do texto apresentado para apreciação dos constituintes ascendeu uma "luz amarela" para os comunistas. A luta pela conformação de uma democracia, com amplas liberdades políticas, estava ameaçada. Por isso, na votação do texto principal os comunistas foram os únicos a se colocarem contra a proposta oriunda da Comissão de Constituição. Nesta ocasião, Prestes leu uma extensa declaração de voto da bancada do PCB, que sintetizava o posicionamento do partido diante dos limites e possibilidades apresentados pelo processo de democratização, em geral, e pela Constituinte, em particular. Embora seguisse insistindo que a Constituinte deveria "buscar a linha média capaz de harmonizar todas as tendências", ou seja, uma forma de consenso, Prestes registrava a insatisfação dos comunistas com o resultado apresentado pela Comissão de Constituição (NETTO, 1986, p. 122):

\begin{abstract}
Votamos contra o Projeto por ser no seu todo e na maioria dos seus capítulos a negação daquilo porque prometemos lutar nesta Casa. [...] O Projeto, no entanto, foi aprovado pelo plenário da Casa e aqui estamos para colaborar, para participar da tarefa de melhorá-lo na medida do possível. Pensamos, também, que a Constituição deve limitar-se à afirmação de princípios fundamentais do regime que se adota e não entrar em detalhes mais próprios de leis ordinárias ou mesmo regulamentos. A grande extensão do projeto não significa que trate de novos assuntos importantes, como chegaram a afirmar alguns de seus defensores. É extenso porque multiplica exceções, e, inúmeras vezes, se põe a limitar, senão a negar, direitos, preceitos e afirmações de próprio projeto (BRASIL, 1946, vol. XIII, p. 363).
\end{abstract}

Como se nota, a crítica dos comunistas não poupou aspectos formais do texto. Mas também o conteúdo do anteprojeto foi objeto da insatisfação da bancada do PCB:

Não se diz nada de prático sobre a reforma agrária, sobre a maneira de acabar com os restos feudais na agricultura, sobre a necessidade de ensino gratuito, sobre a gratuidade indispensável da Justiça, sobre medidas práticas que asseguram o progresso do Brasil (NETTO, op. cit., p. 363).

Inconformados com as limitações do texto apresentado, os comunistas apresentaram diversas emendas. Embora estritamente dentro dos marcos do sistema capitalista, as alterações sugeridas pelos comunistas buscavam aprofundar a democracia em todos os seus aspectos, seja na garantia de direitos fundamentais, seja na conformação de um sistema político o mais permeável possível às pressões populares. Marcadas por uma orientação reformista, as proposições do PCB eram condizentes com a leitura hegemônica entre os comunistas, a partir da qual o tema da "eliminação dos restos feudais" tinha grande importância. Por isso, mesmo 
propondo uma emenda que não questionava o direito à propriedade privada, os comunistas defenderam que este direito não poderia "ser exercido contra o interesse social ou coletivo" ou quando "anulasse, na prática, as liberdades individuais proclamadas pela constituição ou ameaçasse a segurança nacional" (PRESTES, 2001, p. 93). Outra emenda destacava que a propriedade privada estava condicionada "ao bem-estar, de modo que permitam a justa distribuição dele com iguais oportunidades para todos" (Idem). Ao mesmo tempo, a bancada comunista também apresentou emendas que previam:

[a] fixação do homem no campo, tomando as medidas necessárias para o fracionamento dos latifúndios, para o desenvolvimento das pequenas propriedades, para a criação de novo centros de população agrícola com as terras e as águas que lhes sejam indispensáveis (Idem).

Em relação ao sistema político, os comunistas apresentaram emendas que buscavam construir uma alternativa ao presidencialismo, em vigor desde a proclamação da República, mais de meio século antes. Em diversos discursos, os comunistas procuravam associar as variadas experiências autoritárias que marcavam a história republicana do país, à forma presidencialista de governo. Num discurso inflamado, Prestes chegou a afirmar que "em nossa pátria, a verdade é que o presidencialismo tem sido ditadura, sem a ditadura; benéfica ou maléfica, mas sempre a ditadura; o contrário, portanto, da democracia” (NETTO, 1986, p. 145). Por trás da crítica feroz ao presidencialismo, os comunistas defendiam o fortalecimento do legislativo, que segundo eles seria mais permeável às pressões populares. Simultaneamente, os comunistas apresentavam emendas que previam a extinção do Senado Federal, a redução da duração dos mandatos de presidente, senadores e deputados, e a convocação de eleições gerais noventa dias após o fim dos trabalhos da Constituinte. Ainda na perspectiva de ampliar a participação política das classes populares, o PCB propôs, através de uma emenda ao artigo $\mathrm{n}^{\circ} 150$, a ampliação do direito de voto aos marinheiros, cabos, soldados, sargentos e analfabetos. Esse contingente de brasileiros, somados, alcançava a incrível marca de 30 milhões de cidadãos e cidadãs privados do direito ao sufrágio universal (Ibid., p. 146).

Embora o projeto aprovado assegurasse "a inviolabilidade dos direitos concernentes à vida, à liberdade, à segurança individual e à propriedade privada”, propostas que ampliassem ou explicitassem esses direitos nem sempre eram bem recebidas. Emendas que visavam assegurar a livre circulação de livros ou a liberdade de reunião foram rejeitadas. No âmbito das liberdades políticas, o PCB propôs várias emendas para garantir o direito à livre organização dos trabalhadores. Sobre o direito de greve, o texto aprovado previa que, em seu 
artigo $\mathrm{n}^{\circ} 164$, aquele seria assegurado "desde que não prejudicasse o bem público" (ALMINO, 1980, p. 124). Contra este artigo, os comunistas propuseram uma emenda que previa a garantia do pleno exercício do direito de greve. É desnecessário lembrar os efeitos do decreto $\mathrm{n}^{\circ}$ 9070, que estava em vigor e restringia brutalmente a organização política dos trabalhadores. Isolada na defesa de sua emenda e diante de propostas que pioravam ainda mais o texto inicial, a bancada comunista resolveu apoiar a emenda $\mathrm{n}^{\circ} 3221$, apresentada pelo deputado Hermes Lima, da Esquerda Democrática (futuro Partido Socialista Brasileiro), que reconhecia o direito de greve e transferia para a legislação ordinária a sua posterior regulamentação (SANTANA, 2001, p. 52). Entretanto, como lembra João Almino, esta regulamentação já existia e era extremamente severa e restritiva (ALMINO, 1980, p.130).

Em relação à liberdade de imprensa, os comunistas lutaram para assegurar, tanto no texto da Constituição quanto no decorrer de todo o trabalho constituinte, a vigilância ao direito de livre funcionamento dos órgãos de imprensa, especialmente após a decisão do Ministério da Justiça de, baseado no decreto-lei $\mathrm{n}^{\mathrm{o}} 431$ de 1938, fechar por quinze dias o jornal Tribuna Popular, órgão oficial do Comitê Central do PCB. A essa luta aderiram outros parlamentares, especialmente os da UDN, que tinha uma importante presença de jornalistas entre seus quadros. Entre os deputados comunistas, é de Jorge Amado o protagonismo na defesa da liberdade de imprensa, não apenas em favor dos veículos de comunicação comunistas, mas também dos veículos de radiodifusão que viviam sob constante intervenção do Governo Dutra (NETTO, 1986, p. 149).

Os comunistas ainda enfrentaram outra polêmica relacionada à autonomia dos municípios. De acordo com o projeto aprovado pelos constituintes, a autonomia dos municípios não se estendia às capitais, estâncias hidrominerais e municípios com a presença de bases militares, cujos prefeitos seriam nomeados livremente pelos governadores, nem ao Distrito Federal, cujo prefeito seria nomeado pelo Presidente da República (Ibid., p. 170). A emenda $n^{\circ} 2819$, apresentada pelo PCB e defendida pelo deputado Maurício Grabois, eleito pelo Distrito Federal, buscava alterar os artigos 26 e 28 do projeto de Constituição para assegurar a plena autonomia desses municípios. Como a imensa maioria das emendas apresentadas pelos comunistas, a proposta foi rejeitada.

Outra polêmica que merece destaque é aquela relacionada aos temas religiosos. Pelo menos em dois deles os comunistas tiveram atuação destacada. A primeira, diz respeito ao preâmbulo da Constituição, que colocava os constituintes "sob a proteção de Deus". Como acontece hoje em dia, o tema foi objeto de acaloradas discussões. Os comunistas propunham, 
ao contrário, uma redação que não fizesse qualquer menção religiosa. A emenda $\mathrm{n}^{\circ} 2193$ trazia a seguinte redação:

Nós, representantes do povo brasileiro, reunidos em Assembleia Constituinte para organizar um regime livre e democrático que assegure a unidade, o progresso e a soberania da Pátria e o bem-estar do povo, decretamos e promulgamos a seguinte Constituição (NETTO, 1986, p. 173).

Na defesa da proposta, o comunista paulista Milton Caires de Brito fez questão de reafirmar que a posição do PCB não representava qualquer forma de intolerância religiosa, mas que buscava assegurar a liberdade religiosa como direito de foro privado. O mesmo argumento foi utilizado quando os comunistas se opuseram à obrigatoriedade do ensino

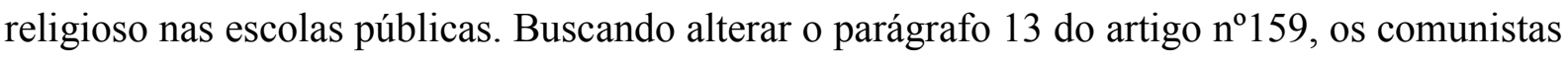
propuseram que o ensino religioso fosse transformado em disciplina facultativa. O máximo que conseguiram foi assegurar o direito de os alunos rejeitarem o ensino religioso mediante manifestação expressa dele ou de seu representante legal (Ibid., p. 172).

Como podemos notar, o esforço dos comunistas, desde a aprovação do texto base e do início da discussão das emendas, foi o de assegurar as condições para a ampliação das liberdades democráticas e dos direitos sociais. Não era pouco numa conjuntura tão complexa e diante de tamanho isolamento. Julgar os limites encontrados neste esforço, à luz do que julgamos hoje ter sido a melhor tática, é um exercício de história contrafactual inútil. Os comunistas, perante condições extremamente severas, buscaram criar as condições para a afirmação de uma verdadeira democracia liberal, coisa que o Brasil não tinha vivido até então. Este projeto, embora muito distante das pretensões revolucionárias do $\mathrm{PCB}$, representava um extraordinário salto de qualidade nas relações políticas ali existentes. Tanto é assim, que basta tomarmos como exemplo o destino da imensa maioria das emendas da bancada comunista rejeitada ou sequer admitida para discussão - para notarmos a correlação de forças extremamente desfavorável a quaisquer propostas democratizantes. Desde o começo se impôs uma forte resistência conservadora, que impediu que se viabilizassem os objetivos do PCB. O erro dos comunistas, no entanto, foi desconsiderar que esta resistência trazia consigo as condições para uma ofensiva muito mais violenta contra os comunistas e seu partido.

\subsection{Ilusões perdidas: a cassação do PCB}

Em 15 de julho de 1946 reunia-se a III Conferência Nacional do PCB. Faltavam apenas dois meses para a promulgação da nova Constituição, que aconteceria em 18 de 
setembro do mesmo ano. Já estavam suficientemente claros os limites do processo de democratização no Brasil, a hegemonia das classes dominantes sobre a Assembleia Constituinte, o caráter predominantemente conservador do governo do General Eurico Gaspar Dutra e o afastamento entre a URSS e as potências aliadas, que lideraram a luta contra o fascismo durante a Segunda Guerra Mundial. O cenário, portanto, mostrava-se cada vez mais difícil para os comunistas. A Conferência seria uma oportunidade de preparar o partido para as intempéries que pareciam avizinhar-se.

O documento aprovado, contudo, parecia reconhecer só parcialmente estas dificuldades. Se por um lado, reconhecia que era preciso engajar as massas "em apoio aos representantes democráticos que na Assembleia Constituinte enfrentam os restos do fascismo e da ditadura na luta pela Carta Constitucional progressista reclamada pelos supremos interesses da nação", por outro, reafirmava os princípios da "união nacional" com base "num programa mínimo de defesa e consolidação da democracia" que reunisse desde o proletariado até a burguesia progressista (CARONE, 1982, p. 67).

Em relação às greves e manifestações populares, a posição do partido também demonstrava dubiedade. Enquanto o partido aconselhava os trabalhadores "a lutarem por melhores salários, porque na medida em que o fizerem, estarão buscando uma saída pacífica para o descontentamento popular", defendia que a "a solução imediata dos problemas da carestia, da fome e da miséria exige cada vez mais a união nacional”.

Além disso, mesmo diante de todos os ataques desferidos contra o partido - que se aprofundaria um mês depois com o fechamento do Tribuna Popular - seguia-se preservando o governo Dutra de ataques mais frontais. Ao reafirmar a posição de "apoio franco e decidido aos atos democráticos do governo" e de "luta intransigente, se bem que pacífica, ordeira e dentro dos recursos legais contra qualquer retrocesso", o documento, aprovado em janeiro do mesmo ano pela Conferência, fez uma ressalva explícita ao afirmar que "o importante é saber desmascarar a camarilha fascista enquistada no governo, mobilizando grandes massas no sentido de exigir sua retirada dos cargos que ainda ocupam" já que "sabemos que o governo no seu todo não é composto de reacionários". O documento seguiu afirmando que "não se justificam ataques em bloco ao governo, porque tal não poderia ser a posição de quem, como nós, luta de fato pela união nacional" (CARONE, 1982, p. 68).

De resto, quase metade do documento é dedicada a orientações de natureza organizativa, como o fortalecimento do trabalho político junto às frentes de massas, em especial junto aos sindicatos e camponeses; o aperfeiçoamento da formação de quadros; e o aprimoramento da imprensa partidária. Ou seja, a III Conferência Nacional praticamente 
ignorava quaisquer riscos à existência do PCB. Tudo parecia concorrer para o fortalecimento do partido. E a promulgação da Constituição, em 18 de setembro, surgiu como confirmação dos melhores auspícios para a democracia brasileira.

Em dezembro, do mesmo ano, reunia-se o Pleno do Comitê Central. O informe político formulado pela Comissão Executiva para aquela reunião não poderia ter um título mais otimista: "Em marcha para um grande partido comunista de massa" (VINHAS, 1982, p. 123). Mesmo reconhecendo que "os agentes do imperialismo sabem que a liquidação de nosso partido é tarefa indispensável", a Comissão Executiva reafirmava a política de "união nacional”, uma política "de prudência e sangue frio, de ordem e paz, de luta corajosa e audaz, dentro da lei, contra as arbitrariedades policiais e na defesa intransigente dos preceitos constitucionais" (Idem). O otimismo não se resumia à conjuntura nacional. Sobre o cenário internacional, os comunistas consideravam que "a democracia avança como avalanche e não poderá ser facilmente vencida". O fortalecimento das chamadas "democracias populares e progressistas" como a Bulgária, a Iugoslávia e a Polônia seriam a prova, junto com o triunfo eleitoral dos comunistas franceses, de que a democracia vivia seus melhores dias. Assim como no Brasil, a presença dos regimes de Franco e Salazar na Espanha e em Portugal, respectivamente, não passava de "restos fascistas", que em breve seriam varridos pelo avanço democrático que tomava o mundo (Idem). Como se vê, o otimismo que dava a tônica do documento em nada fazia supor que o partido teria seu registro cassado dentro de menos de seis meses.

As eleições suplementares de janeiro de 1947 demonstraram a força real do PCB. O partido conquistou $9 \%$ dos votos totais do país, elegendo 64 deputados estaduais às assembleias legislativas de 15 unidades da federação. Só na Câmara Municipal do DF, o partido elegeu 18 vereadores, de um total de 50 cadeiras (Prestes, 2010, p. 102). Além disso, os comunistas ajudariam a eleger dois governadores: Adhemar de Barros, em São Paulo, e Otávio Mangabeira, na Bahia. O primeiro era do pequeno Partido Social Progressista (PSP) e o segundo da UDN. Um resultado que demonstrava o inegável crescimento do PCB durante pouco mais de um ano de vida legal e parecia confirmar, ao olhar dos dirigentes do partido, a justeza da tática de "união nacional". Diante disso, por que o partido deveria se preocupar com as ameaças de cassação?

Acontece que o cenário internacional, contrariando o otimismo pecebista, alterava-se rapidamente. A Conferência de Potsdam (julho/agosto de 1945) já encontrava mais dificuldades que a aquela realizada anteriormente, em Yalta. A chegada de Trumam à presidência dos Estados Unidos (Roosevelt falecera em abril) representava também a 
ascensão dos setores mais anticomunistas ao Pentágono. No ano seguinte, Churchill faria seu famoso discurso em Fulton (EUA), onde anunciou a existência de uma "cortina de ferro" sobre a Europa Oriental. Enquanto isso, os Republicanos conquistavam a maioria no Congresso dos EUA e a guerra civil na Grécia reiniciava (VIZENTINI, 2005, p. 200). Em março de 1947 é proclamada a Doutrina Truman, segundo a qual os Estados Unidos agiriam para proteger os "povos livres" de quaisquer "agressões totalitárias". Menos de três meses depois é lançado o Plano Marshall, com o alegado objetivo de "reconstruir a Europa" e assegurar a influência estadunidense no continente. Como condição, os partidos comunistas foram expulsos dos governos de "frente popular" e se opuseram ferozmente ao Plano Marshall. Com isto, estavam lançadas as bases para a chamada "Guerra Fria” (Ibid., p. 202).

No Brasil, o governo Dutra se considerava merecedor de atenções especiais por parte dos Estados Unidos, por causa da aproximação entre os dois países durante a luta contra o nazifascismo e do empenho do Brasil na criação dos organismos internacionais, liderados pelos EUA no pós-guerra. Além disso, o país contava então com uma Constituição liberal e um sistema pluripartidário livre e democrático, o que colaborava no esforço norte-americano de denúncia aos sistemas "totalitários" (FICO, 2000, p. 171).

O governo Dutra, empenhado em conquistar a condição de parceiro prioritário dos Estados Unidos na América do Sul, alinhou-se desde o começo com a política externa de Washington. No plano interno, isso se traduzia numa mudança radical de postura em relação aos comunistas. Se, como candidato a presidente, Dutra afirmara em relação ao PCB que reconhecia o direito de existência legal - "disputando eleitoralmente sua supremacia" e procurando "por meio de seus representantes influir na vida política e administrativa do país" (VINHAS, 1982, p. 122) -, no exercício de seu mandato, cedia cada vez mais espaço a posições abertamente anticomunistas, em especial no Ministério da Justiça que, como vimos, atuava com o intuito de impedir a livre organização do PCB e sua imprensa.

Desde o início dos trabalhos da Constituinte, os comunistas conviveram com ameaças e perseguições. O primeiro pedido de cassação do registro do PCB, por exemplo, data de março de 1946 e tinha como argumento o alegado caráter "ditatorial e internacionalista" da agremiação. Além disso, acusava-se o partido de estar a serviço da União Soviética e que, em caso de guerra, seus militantes lutariam contra o Brasil. O parecer do Procurador-Geral foi pelo arquivamento do processo, mas o Tribunal optou por não aceitar o parecer e deu prosseguimento à apuração. Outras ações foram impetradas enquanto as investidas contra os comunistas dentro e fora da Assembleia Constituinte eram aprofundadas. Vale destacar que, 
ao votar o capítulo II (sobre os direitos e garantias individuais), foi incluído o artigo $\mathrm{n}^{\mathrm{o}} 141$, parágrafo 13 , que previa que:

É vedada a organização, o registrou ou o funcionamento de qualquer partido político ou associação, cujo programa ou ação contrarie o regime democrático, baseada na pluralidade dos partidos e na garantia dos direitos fundamentais do homem (VILLA, 2011, p. 86).

Em maio de 1947, finalmente, o Tribunal Superior Eleitoral decidiu cassar o registro do PCB por 3 votos a 2, baseado exatamente na acusação de que o PCB recebia uma "firme e cuidadosa orientação político-partidária de procedência estrangeira, baixada das estepes sobre nós, como sobre tantos e tantos outros países" (NETTO, 1986, p. 190). Como observa Daniel Aarão Reis Filho, nota-se um contraste na votação dos ministros que participaram da decisão:

\begin{abstract}
Enquanto os juízes Sá Filho, relator do processo, e Ribeiro da Costa se atinham aos autos numa argumentação exclusivamente jurídica, evidenciando a inconsistência das provas, os demais, José Antônio Nogueira, Cândido Lobo e Rocha Lagoa, que votaram pela cassação, permitiam-se inflamados discursos políticos. O único argumento jurídico dizia respeito ao fato de que a Constituição vedava o funcionamento o funcionamento de partidos de contrariassem o regime democrático, baseado na pluralidade dos partidos e na garantia dos direitos fundamentais do homem. Para eles, o movimento comunista internacional e o PCB em particular eram incompatíveis com o enunciado constitucional (REIS FILHO, 2014, p. 241).
\end{abstract}

Como podemos perceber, a maioria dos ministros se amparou no clima gerado por toda a campanha anticomunista em curso na imprensa, no governo e no próprio parlamento, para viabilizar uma medida estritamente política, com pouca ou nenhuma base legal ,que seria tema da historiografia por muito tempo. 


\section{CAPÍTULO 3}

\section{OS COMUNISTAS E A DEMOCRACIA}

A cassação do registro legal do PCB, em maio de 1947, não teve efeitos imediatos sobre a bancada do partido no Congresso Nacional (já dividido entre Câmara dos Deputados e Senado Federal). A perda dos mandatos comunistas só se consumaria em janeiro do ano seguinte e, até março de 1949, as vagas do PCB não seriam ocupadas por outros partidos. Por ironia do destino, a perda de mandato eletivo não havia sido sequer prevista na nova Constituição. Por isso, foi editada a lei no 648 de 1949, estabelecendo em seu artigo primeiro que:

\footnotetext{
Os lugares tornados vagos nos corpos legislativos, em consequência do cancelamento do registro do Partido Comunista do Brasil, pela Resolução $\mathrm{n}^{\circ}$ 1.841, de 7 de maio de 1947, do Tribunal Superior Eleitoral, caberão a candidatos de outro ou de outros partidos, votados na eleição de que se tenham originado os mandatos (BRASIL, 1949, p. 01).
}

Após a cassação do registro do partido, seguiram-se intervenções em sindicatos controlados pelos comunistas; a CTB seria um dos primeiros alvos da ação do governo Dutra. Em algumas unidades da federação, a repressão aumentaria enormemente, com invasões às sedes regionais do partido e com o fechamento de jornais comunistas, sem qualquer ordem judicial. Mesmo assim, os comunistas mantiveram-se ativos em todo o país, numa espécie de "semilegalidade" (REIS FILHO, 2014, p. 245). Alguns atos isolados em favor do partido foram organizados, mas sem muito sucesso. A onda de apoio esperada pelos comunistas no caso de uma cassação não aconteceu. No Congresso Nacional, os deputados comunistas denunciavam indignados a cassação do registro do partido e subiam o tom contra o governo Dutra. Discutia-se o que seria dos mandatos dos parlamentares eleitos pelo PCB, uma vez cassado o registro partidário. Na tribuna da Câmara, João Amazonas bradava:

\footnotetext{
O que se vai decidir através destes debates - históricos, sem dúvida - é a sorte do próprio regime democrático, instituído no país pela Constituição de 1946. E é por isso, senhores, que a nação está voltada com a maior atenção para a Câmara dos Deputados na expectativa de que seus representantes saibam pesar a gravidade do momento político que atravessamos e, assim, repudiem, com coragem e patriotismo, as manobras do grupo fascista que detém em suas mãos o Poder Executivo Federal (RUY, 2011, p. 124).
}

Em julho, os comunistas teriam uma pequena vitória. Respondendo a uma consulta do PSD, o Tribunal Superior Eleitoral manteria seus mandatos mesmo após a cassação do PCB. Porém, a mesma corte negaria o registro de outro partido criado pelos comunistas - o Partido 
Popular Progressista -, através do qual pretendiam retornar à legalidade (REIS FILHO, 2014, p. 248). Nos primeiros meses após a cassação do registro do PCB, seu líder máximo, Prestes, manteve-se em isolamento total, só reaparecendo a uma sessão do Senado Federal em agosto de 1946 (Idem). Um dos episódios que colocara a opinião pública contra os comunistas havia sido protagonizado justamente por Prestes, meses antes, quando questionado de que lado ficaria no caso de uma hipotética guerra entre Brasil e União Soviética. Num arroubo de sinceridade, ele afirmara que, nesse caso:

\footnotetext{
faríamos como o povo da resistência francesa, o povo italiano, que se ergueu contra Pétain e Mussolini. Combateríamos uma guerra imperialista contra a URSS e empunharíamos armas para fazer a resistência em nossa pátria contra um governo desses, retrógrado, que quisesse a volta do fascismo (PRESTES, 2001, p. 95).
}

Em seu retorno ao Senado, Prestes proferiu um discurso em que denunciava a ofensiva contra a bancada comunista, mas reafirmava o compromisso do partido com a democracia e com o regime constitucional, convocando as forças progressistas a fortalecerem a "união nacional" e restringindo suas críticas aos "elementos fascistas", que cercavam o presidente Dutra. Uma fala defensiva, visivelmente amparada na vã esperança de que os recursos, impetrados junto ao TSE contra a cassação do registro do partido, pudessem ser acolhidos e a legalidade do PCB fosse reconquistada (REIS FILHO, 2014, p. 248). Não obstante a resistência dos deputados comunistas, o partido sofreria um novo revés apenas dois meses após o discurso de seu, então, Secretário-Geral. Em 27 de outubro, o Senado Federal aprovou resolução que cassava os representantes comunistas. Uma semana antes o governo Dutra rompera relações diplomáticas com a União Soviética e ordenara o fechamento de entidades ligadas ao PCB, como a União da Juventude Comunista (UJC) e a Associação Brasileira de Amigos da URSS. Em 10 de janeiro de 1948, o golpe de misericórdia: a mesa da Câmara dos Deputados declarou extintos os mandatos dos deputados e suplentes no PCB (NETTO, 1982, p. 191).

As interpretações sobre as responsabilidades dos comunistas na cassação do registro de seu partido são muitas e têm alimentado acalorados debates historiográficos. Não sendo objeto central deste trabalho, vale a pena somente destacar em poucas linhas a polêmica de fundo em torno do peso atribuído às posições políticas do PCB no processo que levou à sua cassação. Como vimos, o ano de 1946 foi marcado por um retrocesso geral em relação à presença dos comunistas na vida política do país. Enquanto aumentavam as pressões externas, com o início da chamada "guerra fria", no plano interno, as elites fechavam o cerco contra a 
presença dos comunistas no novo ordenamento político-institucional. Isso ficou evidente não apenas nos discursos de parlamentares da UDN, PSD e até PTB, ou nas centenas de editoriais dedicadas a atacar o PCB nos principais jornais do país, mas também nas próprias ações da polícia e do governo Dutra. Portanto, dar um peso excessivo à responsabilidade dos próprios comunistas pela tragédia que os acometeu, como se pudessem eles próprios, de forma isolada, evitar a cassação do partido, parece-nos uma abordagem equivocada, que ignora elementos alheios à governabilidade dos comunistas.

$\mathrm{Na}$ verdade, o processo que levou à cassação do PCB desnudou o caráter extremamente restrito assumido pela democratização "pelo alto", levada a cabo após a deposição de Getúlio Vargas. O cerco aos comunistas e às organizações da classe trabalhadora nunca deixaram dúvidas quanto aos limites do processo de instauração de uma nova ordem democrática representativa. Mas, com a proscrição do PCB, as intervenções nos sindicatos, o rompimento com a política nacionalista de Vargas e a retomada dos postulados do liberalismo econômico, o caráter autoritário do governo Dutra se concretizou plenamente (NETTO, op. cit., p. 193).

Este processo, no entanto, não foi plenamente percebido pelos comunistas. É falsa a ideia de que o PCB já se preparava para o pior, ao reforçar a criação dos Comitês Populares Democráticos ou a organização da CTB, como alguns autores chegam a sugerir (PRESTES, 2010, p. 101). Ao contrário, dispomos de indícios suficientes para sustentar que o PCB subestimou o ódio das elites contra o partido e não interpretou corretamente o novo momento político. Basta notar o discurso proferido por Prestes no dia do julgamento do pedido de cassação, na Casa do Estudante, no Rio de Janeiro, quando afirmou que "a cassação é inviável, o processo judicial parte de inexpressivo grupelho fascista, a burguesia progressista não tem interesse em tamanho disparate” (REIS FILHO, 2014, p. 243). Os comunistas cometeram severo erro de avaliação. $\mathrm{O}$ isolamento do partido era latente e pouco foi feito de eficaz para estreitar os laços do PCB com outros atores sociais antes da cassação do registro do partido. Os apelos à "união nacional" mostraram-se definitivamente inaudíveis. A tática de construção de uma aliança com a burguesia nacional comprovou-se um retumbante fracasso. Em sua biografia, Leôncio Basbaum dá a dimensão da estupefação dos comunistas ao afirmar que:

nenhuma só voz, quer de operários, quer da burguesia, se levantou contra o que era visível e flagrante violência contra os termos expressos na Constituição. Apenas alguns deputados ousaram fazer protestos simbólicos contra um fato consumado (BASBAUM, 1975, p. 89). 
Nos parece evidente, portanto, que os comunistas avaliaram de forma incorreta o cenário, continuando a apostar num avanço ad infinitum da democracia, quando o que se via, na verdade, era o início de uma contraofensiva conservadora.

Essas críticas, no entanto, devem ser examinadas à luz do conjunto da trajetória trilhada pelo PCB. Ademais, os principais objetos da crítica endereçada aos comunistas de 1946, pela historiografia contemporânea, relacionam-se com uma série de questões ainda não resolvidas na formação social brasileira, todas elas constitutivas da problemática da revolução burguesa: as "questões" agrária, nacional e democrática; por isso a dificuldade de estabelecer parâmetros fora da anacrônica dicotomia condenação/absolvição da política do PCB (ALMEIDA, 2003, p. 85). Como lembra João Quartim de Moraes:

\footnotetext{
Embora o fracasso de uma linha política não prove estar errada a teoria que a inspirou, qualquer partido que é levado a criticar pontos fundamentais de seu próprio programa põe em questão sua identidade orgânica e sua legitimidade política. Sem dúvida este é o preço a pagar para manter credível a pretensão de cientificidade do marxismo enquanto teoria revolucionária (MORAES, 2007, p. 47)
}

Por isso, conhecer as condições, que favoreceram a adoção da tática de "união nacional" e alimentaram falsas esperanças de uma democracia ampla e irrestrita entre os comunistas, é indispensável para compreendermos as escolhas feitas pelo PCB a partir de sua reorganização enquanto partido, em 1943. Com o fim da Segunda Guerra Mundial, combinaram-se diferentes fatores que favoreceram a adoção da política de colaboração de classes. No plano teórico, vigorava a interpretação etapista oriunda da Internacional Comunista, segundo a qual a América Latina era considerada uma formação social semifeudal ou semicolonial e, portanto, pré-capitalista. Sendo assim, a tarefa dos comunistas deveria ser a de derrotar as forças do "atraso" com o objetivo de desenvolver um capitalismo industrial moderno para, só depois, passar à etapa da luta pelo socialismo. Nesse arranjo teórico, o papel dos comunistas, como vimos anteriormente, seria o de aliar-se às suas respectivas "burguesias nacionais", para incentivar o desenvolvimento do capitalismo e da democracia. Essa perspectiva teórica vigorava desde o final dos anos 1930, quando a Internacional abandonara a tática da classe contra classe - que colocava os socialdemocratas como inimigos principais a serem combatidos. Quando a política das "frentes populares" foi adotada, no VIII Congresso da Internacional Comunista, não tardou para produzir bons frutos em países como Chile, China, Espanha e França (DEL ROIO, 2007, p. 101) e ser adotada amplamente em todos os países considerados "atrasados" economicamente. 
Essa tática - que, conforme vimos, era hegemônica entre os partidos comunistas na América Latina - ganhou enorme impulso com o final da Segunda Guerra Mundial. A derrota do nazifascismo e a colaboração dos países aliados na luta contra o inimigo comum foram interpretadas como prova do acerto político que representava a colaboração de classes. Noções vagas como "progresso", "democracia" e "paz" foram rapidamente incorporadas ao vocabulário dos comunistas, que antes privilegiavam conceitos como "luta de classes" e "ditadura do proletariado". Essa interpretação, no entanto, não foi aceita sem resistências no interior do PCB. Além das críticas oriundas no núcleo paulista - do qual fazia parte Caio Prado Júnior, dentre outros -, havia também resistências à colaboração com o governo Vargas, o que alimentou dissidências e resistências internas (PANDOLFI, 1995, p. 138).

Uma vez vitoriosa a política de colaboração com a burguesia nacional, a linha tática adotada privilegiou as chamadas "tarefas democrático-burguesas". Essas tarefas, basicamente, respondiam à necessidade de "destravar" o desenvolvimento das relações capitalistas de produção, de construir um sistema político democrático (nos marcos da democracia liberal) e de assegurar a soberania nacional dentro da nova ordem internacional pós-guerra. No plano econômico, ganhava relevância a reforma agrária - vista como forma de superar os "vestígios feudais" no campo - e a industrialização - como meio de garantir melhores condições de vida às massas urbanas e diminuir o poder das multinacionais na economia brasileira. Como se vê, a linha política privilegiava as questões democrática e nacional, mais que a perspectiva classista ou de construção de uma vanguarda proletária (ALMEIDA, 2003, p. 87).

\subsection{O PCB e a democracia representativa}

Mesmo assim, a questão de fundo que se apresenta em diversas abordagens historiográficas é em que medida os comunistas estavam realmente comprometidos com a construção de um sistema democrático em 1945. Para Leandro Konder, por exemplo, havia um compromisso tênue no PCB com as instituições democráticas no Brasil. Prova disso seria o fato de, após excluídos do jogo democrático, os comunistas defenderem o voto em branco nas eleições de 1950 e recorrerem à criação de sindicatos paralelos, negando a validade da participação nas instituições do novo regime (KONDER, 1980, p. 127). Já Berenice Cavalcante oferece-nos uma interpretação mais complexa, segundo a qual, por ser reduzida à sua dimensão jurídico-institucional, a questão democrática ocupa lugar cada vez mais secundário nas formulações dos comunistas na medida em que são asseguradas conquistas como a própria legalização do $\mathrm{PCB}$, a existência de uma imprensa livre e o funcionamento do 
Congresso Nacional. Segundo a autora, a não ser em referências esparsas sobre a defesa da democracia contra as "ameaças fascistas", o tema não ganha maior importância no discurso dos comunistas, que em nenhum momento se propõem a defender sua ampliação para outros campos para além das instâncias governamentais (CAVALCANTE, 1986, p. 170). Para Daniel Aarão Reis Filho, a cassação do registro do PCB deve-se, ao mesmo tempo, a uma confiança desmedida na frágil democracia que nascia e a um desprezo por seus limites:

O partido não se preparara para enfrentar a hipótese de cassação do registro legal, o
que exprimia um envolvimento, talvez demasiado, nas lutas institucionais.
Cretinismo parlamentar? Atualizava-se a velha crítica de Marx aos revolucionários
que se deixavam prender à atmosfera dos parlamentos, esquecendo ou subestimando
os conflitos em curso nas sociedades em que viviam. Por outro lado, para além dos
discursos, era duvidoso que os comunistas acreditassem mesmo naquele processo
democrático. Prova disso era a atmosfera de iniciados que ainda predominava,
herança do Estado Novo, povoada de segredos, marcada pela rispidez no trato, pelo
dirigismo vertical, sem falar na excessiva preocupação com a segurança, como se
revólveres e metralhadoras pudessem garantir alguma coisa; havia ali uma nostalgia
de enfrentamentos apocalípticos (REIS FILHO, 2014, p. 246).

A afirmação de Reis Filho, no entanto, contraria os inúmeros indícios de que os comunistas estavam pouco preparados para retomar a estrutura de quadros gradualmente substituída por uma estrutura de massas ao longo de 1946 (PANDOLFI, 1995, p. 169). Ao mesmo tempo, se a dinâmica do partido pode nos dizer muito sobre sua relação com a democracia, como veremos mais adiante, não nos parece explicação suficientemente consistente aquela que vê a derrota do PCB e sua cassação apenas como resultado de um falso compromisso com o processo de democratização da sociedade brasileira. Essa, aliás, é a mesma perspectiva de outros autores que, nas palavras de Brandão, consideram que a democracia política depende da organização democrática do ator político, e dimensiona a política brasileira com as lentes e os problemas colocados na vida interna do PCB (BRANDÃO, 1997, p. 35). É como se existisse a História do Brasil e, paralelamente, a história do partido, que, a rigor, se inscreveria na história do movimento comunista internacional, imune às vicissitudes da dinâmica histórica brasileira.

Neste plano, a relação dos comunistas com a democracia é tomada como um ponto de inflexão. Seriam os comunistas "verdadeiros" democratas? Ou consideravam a democracia um elemento instrumental no caminho rumo ao socialismo? Um discurso proferido em 1946 por Luís Carlos Prestes dá algumas pistas:

Para o proletariado de nossa terra, não se trata ainda da conquista de sua emancipação revolucionária, mas de conquistar o terreno para lutar por ela. E esse terreno pode ser grandemente ampliado se soubermos convenientemente e 
inteligentemente utilizar o sufrágio universal e o parlamento burguês (PANDOLFI, 1995, p. 144).

Notamos, em primeiro plano, a perspectiva claramente "etapista" explícita na mensagem do secretário-geral, segundo a qual o momento não era "ainda o da emancipação, mas de conquistar o terreno para lutar por ela". Isto é, a luta por um sistema liberaldemocrático melhora as condições para o desenvolvimento da luta pelo socialismo, objetivo final do partido da classe operária. Ao mesmo tempo, em segundo plano, está a relação aparentemente "instrumental" que a democracia representativa teria para os comunistas: ela seria um mecanismo que, se fosse utilizado de forma inteligente, poderia ajudar a conquistar aquele que é o fim último dos comunistas: que é a revolução social e a construção da sociedade socialista.

Outros autores, ao contrário de Reis Filho e Konder, atribuem a cassação dos comunistas em 1946 justamente ao seu "comprometimento excessivo" com as formas parlamentares de luta política, à confiança exageradamente depositada no processo de democratização, enfim, ao desmedido envolvimento com a democracia liberal-burguesa. É o caso das análises de Francisco Weffort, em menor medida compartilhadas por Dulce Pandolfi e Giovanetti Netto. Para Weffort, a linha política adotada pelo PCB entre 1945 e 1947 - a defesa da ordem democrática e da legalidade institucional - foi a grande responsável pela permanência do atrelamento da classe trabalhadora ao Estado e às lideranças políticas nacionalistas e populistas (WEFFORT, 1979, p. 12). Para Dulce Pandolfi, chama a atenção a mudança brusca da tática do PCB a partir de 1948, o que demonstraria o quanto o partido havia se afastado de sua identidade classista:

Se antes o partido tinha uma visão linear sobre os avanços do processo democrático, a noção de retrocesso parecia ter sido incorporada à visão do PCB. Durante a vigência da tese da União Nacional, sem fazer referência à terminologia marxista de luta de classes, os comunistas propunham uma política de cooperação entre o capital e o trabalho. Agora, porém, o partido chamava a atenção 'para a ativa luta de classes que se trava no país' (PANDOLFI, 1995, p. 170).

Como se o PCB estivesse "iludido" com as promessas do regime liberal-democrático, agora o partido despertara para a dura realidade de que, a rigor, jamais deveria ter confiado na possibilidade de convivência pacífica com seus adversários. O próprio Prestes afirmou isso ao Comitê Central em 1948. Nas suas palavras a cassação do PCB e de seus parlamentares "vieram despertar, fazer compreender aos que ainda não haviam compreendido e aos que se deixaram levar tranquilamente pelas ilusões reformistas" (CARONE, 1982, p. 99). Para Lúcio 
Flávio Rodrigues de Almeida, no período entre 1945 e 1947 as posições do PCB dificilmente podem ser criticadas por descaso em relação à democracia burguesa. Mesmo apontando as limitações do regime, o partido denunciou corretamente que este poderia sofrer restrições ainda maiores e procurou arregimentar forças para combatê-las (ALMEIDA, 2003, p. 90). Analisando a atuação dos comunistas na Assembleia Constituinte, Evaristo Giovanetti Netto assevera que:

O PCB deixou-se enredar pela trama de um processo determinado pelas linhas de continuidade e permanência e foi surpreendido por uma ofensiva dos grupos detentores do poder e do aparato burocrático e militar que não poupou os comitês do partido e as redações de seus jornais impondo aos comunistas a retração e o isolamento, revivendo práticas da ditadura e desfechando renovados golpes contra as conquistas de 45 (NETTO, 1982, p. 195).

Ele considera, ainda, que, apesar dos bons resultados eleitorais e do crescimento do PCB, a tática da "união nacional" não deve ser avaliada apenas em termos quantitativos. O que determinaria o sucesso ou o fracasso daquela política seria sua capacidade de, optando pela institucionalização, viabilizar um projeto de democratização consequente. Para ele, reside precisamente neste ponto a vulnerabilidade do projeto do PCB no período: a inflexibilidade do modelo teórico, o otimismo injustificado no pós-guerra e a falta de agilidade da direção teriam comprometido a ação política dos comunistas (Ibid., p. 194).

Como se vê, a relação dos comunistas com o processo de democratização da vida política do Brasil a partir de 1945 é fonte de importantes controvérsias historiográficas. Enquanto alguns atribuem ao PCB uma posição excessivamente passiva e otimista em relação ao processo de construção de uma institucionalidade liberal-burguesa que pudesse comportálos; outros acreditam que o grande erro do partido foi ter mantido, nos subterrâneos de sua direção política, um indisfarçável desprezo pela democracia representativa e pelas novas instituições que surgiam no processo de democratização. Além disso, muitas análises simplesmente ignoram as transformações que se processavam como parte da dinâmica geral da sociedade brasileira e da luta política entre diferentes blocos de poder. $\mathrm{O}$ tratamento psicologizante do partido (ingênuo, cínico, otimista) ajuda a aprofundar o fosso entre sua condição de sujeito coletivo, organizado em torno de um projeto político, e a realidade social historicamente constituída ao seu redor.

Nos parece bastante claro que os comunistas outorgaram seus melhores esforços na construção de um regime democrático. Isso se comprova não apenas pelos documentos do partido, pela orientação em vigor no plano do movimento comunista internacional ou pelo 
empenho de seus militantes na defesa da nova ordem institucional. Mas, sobretudo, pelas condições históricas que se abriram - e que foram corretamente identificadas por sua direção - para a transformação do PCB em um partido de massas. Esse projeto, perseguido por todos os partidos comunistas do hemisfério ocidental, tinha como objetivo, evidentemente, ampliar a influência comunista junto aos setores populares com vistas a fortalecer uma alternativa socialista.

Não está suficientemente claro em que medida os comunistas assimilaram uma visão efetivamente gradualista da chegada ao socialismo ou se, de fato, concebiam a ruptura revolucionária como etapa incontornável para a superação do capitalismo. De qualquer forma, não nos parece justo, sob nenhum ponto de vista, atribuir a um "descompromisso" do PCB em relação à democracia a causa por sua derrota em 1947. Optar por essa interpretação significaria ignorar o contexto nacional e internacional de ofensiva contra os comunistas em todo o mundo, além de todos os esforços do PCB na defesa da nova ordem que surgia, inclusive com apelos inflamados à "ordem" e à "tranquilidade". Como lembra Mazzeo, a política de colaboração sofreria uma interrupção não por iniciativa dos comunistas; ao contrário, estes estiveram todo o tempo empenhados em construir um partido para atuar dentro da legalidade liberal democrática (MAZZEO, 1999, p. 73).

O pensador italiano Norberto Bobbio lembra que, embora o termo "democracia" carregue consigo diferentes significados, existe um sentido preponderante segundo o qual democracia se entende como um conjunto de regras (as chamadas "regras do jogo") que consentem a mais ampla e segura participação da maior parte dos cidadãos de forma direta ou indireta nas decisões que interessam a toda coletividade (BOBBIO, 2001, p. 55). De acordo com essa concepção ampla do termo, não há quem possa questionar o compromisso do PCB com a instauração de uma certa democracia. O fato de que ela seja "qualificada" (burguesa, liberal ou oligárquica), ao contrário do que pensa Bobbio e outros defensores da tese da democracia como "valor universal", em nada diminui a qualidade do apoio dado pelos comunistas na luta por sua instalação em 1945/1946, por vezes até sacrificando compromissos classistas muito caros ao PCB.

Ademais, como discutimos no primeiro capítulo deste trabalho, a questão refere-se à existência de especificidades que distinguem os partidos comunistas dos demais: enquanto podemos circunscrever os objetivos das demais agremiações partidárias à máxima duvergeriana de "aspiração ao exercício do poder" (um poder pré-determinado pelas condições histórico-sociais), os comunistas proclamam a necessidade de construção de uma nova ordem social e política que transcende os limites do próprio exercício do poder. Se sua 
relação com a democracia é propriamente ética, política ou utilitarista, não consideramos que seja suficiente para determinar a ausência de compromisso democrático por parte do $\mathrm{PCB}^{46}$.

Além disso, sempre é bom lembrar que não existem agremiações partidárias cuja razão de ser seja, simplesmente, a defesa das "regras do jogo". A democracia, assim, é sempre um meio para viabilizar a chegada de um partido (ou de um conjunto deles) ao poder. Ou seja, no máximo um meio que serve a um fim.

Como foi dito, não é o objetivo deste trabalho aprofundar a questão da relação entre democracia e socialismo, tema que dispõe de uma vasta produção bibliográfica. Mas devemos destacar que as formulações do PCB, observando a necessidade de instauração de uma "democracia progressista" 47 , antecipa problemáticas que só voltarão a ser abordadas algumas décadas depois. Como afirma Lucio Magri acerca do pensamento de Gramsci:

\begin{abstract}
Resulta claro que el desarrollo de la concepción leninista del partido, la tentativa de superar los límites históricos, se completa com Gramsci em una dirección en todo opuesta a la de la socialdemocracia. Es decir, sin tratar de minimizar el carácter de vanguardia del partido, su extrañeza y su antagonismo radicales respecto de sistema, sino, por el contrario, llevando hasta las ultimas consecuencias el concepto de vanguardia, subrayando la capacidad del partido para imprimir a cada lucha un valor general, para ordenarla de acuerdo com um proyecto global, de darle así significado de ruptura. Es por eso que, sin separar jamás el momento previo a la conquista del poder del momento posterior, sin dogmatizar nunca formas particulares de administración del estado, Gramsci permanece, sin embargo, profundamente ligado al concepto de crisis revolucionaria y de dictadura proletaria, haciendo así una discriminacion precisa entre una sociedad capitalista y una sociedad socialista en términos de la sustitución de clase dirigente y de la transformación de las bases de la sociedad. (MAGRI, 1977, p. 54).
\end{abstract}

Claro que os pecebistas se viam inscritos na tradição "leninista" dos partidos comunistas, segundo a qual cada partido comunista nacional era uma versão local da tradição bolchevique inaugurada por Lenin e atualizada por Stálin. Não tinham superado intelectualmente as formas de interpretação da realidade baseadas na tomada violenta do poder, na ditadura do proletariado e na primazia do partido comunista como vanguarda da classe operária (embora, como vimos, já existissem tendências nessa direção), muito menos

\footnotetext{
${ }^{46}$ Segundo Bobbio, a perspectiva ética é aquela que pode ser identificada na famosa definição rousseauniana de liberdade, segundo a qual liberdade é a obediência às leis que cada um se determinou; trata-se da chamada "liberdade positiva". A perspectiva política é aquela cuja preferência pela democracia se justifica pelo fato de ser ela o principal remédio contra o abuso de poder. A terceira perspectiva, utilitária, acredita que a democracia é preferível à autocracia por acreditar que os melhores intérpretes dos interesses coletivos são os próprios interessados, fazendo da democracia uma "soma de opiniões" (BOBBIO, 2001, p. 85).

${ }^{47}$ O informe político da Comissão Executiva ao Pleno do Comitê Nacional, de dezembro de 1946, afirmava que "lutando pacificamente, e pelos meios estritamente legais, podemos chegar à democracia progressista capaz de assegurar a solução progressiva dos mais sérios problemas do nosso povo" (VINHAS, 1982, p. 124).
} 
conheciam a abordagem de Gramsci sobre o papel dos partidos comunistas nas sociedades ocidentais.

A questão de fundo é verificar em que medida os comunistas brasileiros, como afirma Magri, conseguiram levar às últimas consequências o conceito de "vanguarda política" da classe operária para dar a cada luta um valor geral e organizá-la de acordo com um projeto global que apontasse no sentido da superação de uma determinada realidade histórica marcada pela injustiça social, pela subordinação internacional, pelo atraso econômico e pelo autoritarismo político. E se fizeram isso livrando-se da "camisa de força" da bolchevização levada a cabo pelo partido desde sua reorganização - ou até mesmo contra ela (BRANDÃO, 1997, p. 51).

\subsection{Dinâmica da bancada comunista na Assembleia Constituinte}

O fato de estar, como acreditamos, profundamente comprometido com a construção de uma ordem política democrática no imediato pós-guerra, não é suficiente, contudo, para considerarmos o PCB um partido efetivamente democrático (assim como também não podemos considerar o contrário verdadeiro). O processo de "bolchevização" político e intelectual do partido nos anos 1930, resultado da uniformização dogmática dos partidos comunistas em todo mundo (a partir das diretrizes da Internacional Comunista), já foi vastamente abordado por diversos autores ${ }^{48}$ e comprova os efeitos danosos deste processo para a formação de um ambiente político aberto à crítica e à autocrítica. Como lembra Moraes, porém, a importância do fator internacional não pode ser exagerada: mesmo nos marcos do processo de "uniformização" dos partidos comunistas surgiram interpretações inovadoras como as de José Carlos Mariáteghi, no Peru, ou Mao Tsé Tung, na China (MORAES, 2007, p. 71).

$\mathrm{O}$ processo de reorganização do $\mathrm{PCB}$, que teve seu ápice com a Conferência da Mantiqueira, em 1943, não ignorou o acúmulo dos vinte anos anteriores, nos quais os comunistas brasileiros se esforçaram por compreender o marxismo e aplicá-lo como método de interpretação da realidade. As tentativas mais relevantes nesse sentido, até a reorganização do partido, haviam sido empreendidas por Otávio Brandão em seu Agrarismo e

\footnotetext{
${ }^{48}$ Sobre a evolução política e organizativa dos comunistas brasileiros, recomendamos o artigo $A$ evolução da consciência política dos marxistas brasileiros de João Quartim de Moraes. In: MORAES, J. Q. de. História do Marxismo no Brasil. vol. II. Campinas: Editora da Unicamp, 2007. Sobre a stalinização dos partidos comunistas na América Latina, ver a excelente introdução de Michel Löwy ao seu Marxismo na América Latina. In: LÖWY, M. Uma antologia de 1909 aos dias atuais. São Paulo: Editora Fundação Perseu Abramo, 2012.
} 
Industrialismo, obra de 1928, em que busca descrever as principais classes sociais e relações de produção no Brasil (MORAES, 2007b, p. 139). Depois disso, a maioria das interpretações seriam condicionadas às leituras oriundas da Internacional Comunista para os países da "periferia do capitalismo", como a construção das chamadas Frentes Populares Antifascistas.

Os homens que reorganizaram o partido em 1943 e foram eleitos em 1945 traziam consigo toda essa experiência. Ao passo em que ainda mantinham uma dependência intelectual dos "centros irradiadores" da ideologia oficial; era uma nova geração que assumia o controle de um partido esfacelado pelo Estado Novo e marcado por cisões e expurgos, o que promovia uma alta rotatividade entre seus dirigentes ${ }^{49}$. Mesmo assim, como vimos no capítulo anterior, o PCB lançou candidatos em todos os estados (feito igualado apenas por PSD e UDN) e elegeu deputados em seis unidades da Federação (BA, PE, DF, RJ, SP e RS), a maior parte concentrada na região sudeste, a mais industrializada do país. Só em São Paulo foram quatro deputados. Além disso, 12 dos 15 eleitos pelo PCB haviam sido presos políticos durante o Estado Novo. O partido contava ainda com uma bancada bastante jovem e com o mais baixo nível de instrução (a maioria não possuía curso superior). Embora tenha tido seu melhor desempenho eleitoral no Distrito Federal (alcançando 21\% dos votos), também obteve um resultado significativo no Nordeste, onde elegeu quatro deputados (um na Bahia e três em Pernambuco). A maioria da bancada comunista, aliás, tinha origem nordestina: nove deputados (BRAGA, 1998, p. 79).

Embora jovem, a bancada eleita pelo PCB era formada por quadros com alguma experiência, muitos deles vinculados ao trabalho no movimento sindical ou na organização política do partido. Não dispomos de dados que possam atestar que a direção do PCB tenha estimulado alguma política que privilegiasse os nomes eleitos (a não ser Prestes, candidato prioritário do partido ao Senado ${ }^{50}$. Porém, a eleição tanto de dirigentes políticos do partido quanto de uma expressiva representação de líderes operários demonstra que o PCB soube tirar proveito do trabalho político desenvolvido junto aos trabalhadores e do prestígio de que gozavam algumas de suas lideranças.

Entre os principais líderes do PCB eleitos estavam Carlos Marighella, Maurício Grabois, Jorge Amado, João Amazonas, Milton Caires de Brito, Alcedo Coutinho e, claro,

\footnotetext{
${ }^{49}$ Sobre a rotatividade dos dirigentes do PCB cf. RODRIGUES, L. M. "O PCB: Os dirigentes e a organização". In: FAUSTO, B. (Dir.). História Geral da Civilização Brasileira. Rio de Janeiro: Bertrand Brasil, 1997, volume III, tomo 10 .

${ }^{50}$ Leôncio Martins Rodrigues sugere que "Os deputados de origem popular provavelmente foram escolhidos para fins de demonstração do caráter operário do PCB ou por razões de seu eventual prestígio eleitoral". Não está claro em que ele baseia seu ponto de vista, razão pela qual esperamos a produção de novas pesquisas que possam elucidar o tema (RODRIGUES, 1997, p. 407).
} 
Luís Carlos Prestes. O Secretário-Geral do partido vinha do movimento tenentista dos anos 20 e notabilizou-se nacionalmente com a marcha protagonizada por ele pelo interior do Brasil para denunciar as injustiças da Primeira República. A "Coluna Prestes", como fícou conhecida, projetou Prestes como liderança nacional antes mesmo de sua entrada no Partido Comunista. Com o ingresso no PCB e o levante de 1935, Prestes tornou-se o preso político mais popular do Estado Novo. A campanha por sua libertação mobilizou milhares de pessoas no Brasil e no exterior. Não é de espantar, portanto, que ele tenha surgido como uma das figuras mais carismáticas da nascente democracia brasileira e tenha logrado um resultado eleitoral tão excepcional - já que, além de senador, Prestes obteve expressiva votação para deputado em vários estados.

O baiano Carlos Marighella foi líder estudantil em Salvador antes de ingressar no PCB. Preso pela primeira vez em 1932, retomou sua militância estudantil até ser convocado pela Direção Nacional do PCB. A partir de então atuou clandestinamente no Rio de Janeiro e em São Paulo, até ser novamente preso em 1936. Saindo da prisão, procurou reorganizar clandestinamente o PCB em São Paulo até ser novamente preso em 1938, permanecendo no cárcere até a anistia de 1945. Na ocasião, Marighella já havia sido eleito membro do Comitê Central do partido na Conferência da Mantiqueira e era um quadro respeitado no partido, especialmente pela forma com que resistiu à brutal tortura imposta a ele em suas passagens pela prisão no final dos anos 30 (Ibid., p. 233).

O também baiano Maurício Grabois iniciou sua militância na Juventude Comunista, dedicando-se à organização do partido nas Forças Armadas durante seu curso na Escola Militar (1932-1933). Militou na ANL e durante o Estado Novo atuou na clandestinidade, sendo preso em 1941. Libertado, foi um dos principais membros da Comissão Nacional de Organização Provisória (CNOP) e um dos principais organizadores da II Conferência Nacional do PCB, onde foi eleito membro no novo Comitê Central. Secretário Nacional de Divulgação e Secretário Nacional dos Setores de Massa e Eleitoral do PCB (1943-1945), foi novamente preso em decorrência da onda repressiva desencadeada por ordens do Chefe de Polícia do Distrito Federal, Coriolano de Góis, em dezembro de 1944. Na democratização foi editor do jornal A Classe Operária, órgão do PCB a partir de 1945 (Ibid., p. 295).

O paraense João Amazonas também era um quadro experiente no partido. Participou da Revolução de 1930 na região norte e incorporou-se à ANL tornando-se membro do comitê estadual do PCB em 1935. Preso no mesmo ano, tornou-se diretor da União Geral dos Sindicatos Proletários do Pará em 1936, logo após ser libertado. Durante o Estado Novo militou clandestinamente no movimento sindical, tendo sido responsável pela organização de 
vários sindicatos. Por essa atividade, foi preso em diversas ocasiões entre 1936 e 1940. Após fugir da prisão, deslocou-se clandestinamente para o Rio de Janeiro onde participou ativamente do trabalho de reorganização do PCB. Também foi membro da CNOP, sendo eleito Secretário do Trabalho Sindical e de Massas e membro do Comitê Central do PCB na Conferência da Mantiqueira. Na transição democrática destacou-se como um dos principais dirigentes do PCB, sendo reconduzido ao Comitê Central do partido PCB em 1945 (RUY, 2011, p. 19).

O escritor, jornalista e advogado Jorge Amado filiou-se à Juventude Comunista e ao PCB em 1932, sendo eleito membro do Comitê Dirigente da Juventude Comunista dois anos depois. Redator de $A$ Manhã, órgão da ANL, durante o Estado Novo teve um de seus romances, Capitães de Areia, apreendido em todo o País e queimado em praça pública (BRAGA, 1998, p. 724). Embora já fosse um escritor famoso, seus livros foram retirados de circulação pela censura, o que o estimulou a exilar-se primeiro na Argentina e depois no Uruguai, tendo sido preso por várias vezes entre 1941 e 1943. De volta ao Brasil, foi delegado pela Bahia e um dos vice-presidentes do I Congresso Brasileiro de Escritores, realizado em São Paulo (Ibid., p. 725).

O médico Milton Caires de Brito não chegou a ser eleito pelo PCB em São Paulo, tendo ficado na primeira suplência da legenda naquele estado. A vaga ficara com o ferroviário Mário Scott. No entanto, o partido forçara a renúncia de Scott para que Caires de Brito pudesse assumir sua vaga ${ }^{51}$. Com uma trajetória comum a outros deputados comunistas, foi membro da UJC a partir de 1935. Durante o Estado Novo, deslocou-se para São Paulo, onde foi um dos principais organizadores do PCB na clandestinidade, colaborando decisivamente para a reorganização do partido através da CNOP e sendo eleito membro de sua Direção Nacional na Conferência da Mantiqueira, da qual foi um dos principais organizadores. No contexto da democratização tornou-se membro do Comitê Central do PCB em agosto de 1945 (NETTO, 1982, p 74).

O também médico Alcedo de Moraes Coutinho foi eleito por Pernambuco. Participou do movimento tenentista na década de 1920 e tomou parte na Revolução de 1930, participando da marcha das forças revolucionárias no Estado da Bahia. Participou da ANL e do levante comunista de 1935 em Recife, sendo preso logo em seguida. Durante o Estado

\footnotetext{
${ }^{51}$ Segundo recorda Moisés Vinhas, "o ferroviário Mário Scott, eleito deputado à Constituinte, foi forçado a renunciar em favor do primeiro suplente, Milton Caires de Brito. Quando se discutiu o problema, em reunião na sede do Comitê Municipal, no Brás, Diógenes Arruda surpreendeu-se com a resistência de Scott à renúncia, que chegou a chorar e falar em suicídio" (VINHAS, 1982 p. 91). Efetivamente, Mário Scott se suicidou anos depois.
} 
Novo, após ser solto através de habeas corpus, foi deportado para o Rio de Janeiro, onde retomou sua militância clandestina no PCB (BRAGA, 1998, p. 511).

Esses deputados formavam a bancada dos "parlamentares letrados" do partido. Além de terem destacada atividade parlamentar e legislativa, tinham posições de comando na estrutura hierárquica do PCB e, não raro, assumiam posições de direção junto aos órgãos de imprensa do partido. Em sua maioria eram militantes profissionais, embora todos contassem com formação superior. Representavam menos da metade da bancada do PCB e somaram, nominalmente, pouco menos de 68 mil votos (sem contar a votação de Prestes, que foi candidato por vários estados diferentes). Apesar disso, ocuparam as principais posições no interior da Assembleia Constituinte.

No outro extremo da bancada do PCB estavam os "deputados operários". Eram a maioria da bancada do partido e somavam, nominalmente, mais de 112 mil votos. Só o exsargento do exército, José Maria Crispim, recebeu sozinho quase um terço deste montante: 36.657 votos. Essa bancada, apesar de receber mais votos e ser numericamente superior, ocupava espaços menos destacados na hierarquia partidária (em geral, membros do Comitê Central, não da Comissão Executiva Nacional) e tiveram papel secundário nos trabalhos da Assembleia Constituinte. A bancada operária do PCB era formada por Gregório Bezerra, Claudino José da Silva, Batista Neto, Abílio Fernandes, Alcides Sabença, Agostinho de Oliveira, Osvaldo Pacheco e José Crispim.

O pernambucano Gregório Bezerra, analfabeto até os 25 anos, experimentou atividades profissionais como a de operário da construção civil e entregador de jornais. Ingressou nas Forças Armadas em Pernambuco, onde permaneceu por 14 anos e alcançou o posto de sargento. Filiou-se ao PCB em 1930 e participou do levante de 1935, razão pela qual acabou expulso do Exército e condenado a 28 anos de prisão. Beneficiado pela anistia concedida aos presos políticos em 1945, participou ativamente da reorganização do partido em Pernambuco até ser eleito, em dezembro do mesmo ano, à Assembleia Constituinte com 14.341 votos (NETTO, 1982, p. 74).

O operário Agostinho Dias de Oliveira começou a trabalhar na Usina Santa Rita ainda adolescente. Iniciou sua militância política como caldeireiro na Great Western (1926) e durante o Estado Novo trabalhou como ajustador mecânico na Ford (1941-1943). Ingressou no PCB em 1929, sendo dirigente e membro da Comissão de Finanças da ANL em Pernambuco, tendo sido preso por diversas vezes em razão de sua atuação no movimento de 1935. Foi deportado para o Pará entre 1937 e 1938 e novamente detido em 1940. Conseguiu fugir da prisão, atuando clandestinamente em vários Estados e sendo eleito membro do 
Comitê Central do PCB na Conferência da Mantiqueira, embora não tenha podido comparecer pessoalmente à reunião. Reorganizou o PCB no Rio Grande do Sul e foi eleito deputado à Constituinte em 1945 com 5.160 votos (BRAGA, 1998, p. 510).

Operário do arsenal da Marinha, Joaquim Batista Neto nasceu no Ceará e ingressou no PCB em 1931. Como secretário político da célula do partido naquele arsenal, organizou o trabalho político dos comunistas chegando à presidência da Sociedade de Defesa dos Trabalhadores do Arsenal de Marinha da Ilha das Cobras, entre 1943 e 1945, durante o Estado Novo. Foi também presidente do Comitê Metropolitano do MUT no Rio de Janeiro nos anos de 1944 e 1945, quando se converteu numa das principais lideranças operárias do PCB em todo o país. Assumiu a cadeira de deputado na Assembleia Constituinte na vaga de Luís Carlos Prestes, que optou pelo Senado (NETTO, 1982, p. 73).

O também operário Abílio Fernandes, assim como Batista Neto, também foi beneficiado pela legislação de época que permitiu que Prestes fosse candidato por várias unidades da federação. Como primeiro suplente, Fernandes assumiu a cadeira que o Secretário-Geral deixara vaga no Rio Grande do Sul ao optar pelo mandato no Senado Federal. Natural de Pelotas, Fernandes iniciou sua militância no movimento sindical, atuando nos chamados "sindicatos livres" no início dos anos 30. Filiou-se ao Sindicato dos Operários Metalúrgicos e assumiu a tesoureiro da entidade em 1934. No final dos anos 1930 foi eleito presidente da União Sindical Pelotense e através desta entidade torna-se um dos principais dirigentes da greve do Sindicato dos Graniteiros de Capão do Leão, na qual tomam parte cerca de 600 trabalhadores. Em virtude destas atividades, é preso e processado por diversas vezes durante o Estado Novo. Participou da Conferência da Mantiqueira e foi eleito membro do Comitê Central do PCB, e dois anos depois, Deputado à Assembleia Constituinte com 5.947 votos (BRAGA, 1998, p. 590).

O líder sindical Osvaldo Pacheco nasceu em Sergipe e foi eleito com os votos dos estivadores do porto de Santos (SP). Militou em várias campanhas operárias e chegou à presidência do Sindicato dos Estivadores e à direção da Confederação dos Trabalhadores do Brasil (CTB). Após a vitória do franquismo na Guerra Civil Espanhola, participou do movimento dos trabalhadores do Porto de Santos que se recusaram a descarregar navios espanhóis em 1940. Filiou-se ao partido alguns meses antes do processo eleitoral, contrariando a trajetória da maioria dos deputados do partido. Foi eleito com expressivos 18.460 votos (NETTO, 1982, p. 77).

O operário metalúrgico Alcides Sabença foi eleito pelo PCB do Rio de Janeiro com 6.403 votos. Quando conquistou o mandato à Constituinte, Sabença tinha apenas 30 anos e 
trabalhava na Companhia Siderúrgica Nacional. Filiou-se ao PCB em 1931, então com 16 anos e exerceu intensa atividade política em vários movimentos sociais de trabalhadores, como a Juventude Estudantil Operária Popular e a Aliança Nacional Libertadora. Já no contexto da democratização do país, foi eleito Secretário Político do Comitê Distrital do PCB, em Volta Redonda (RJ), e um dos fundadores do Sindicato dos Trabalhadores nas Indústrias Metalúrgicas, Mecânicas e de Material Elétrico de Barra Mansa, no mesmo estado.

O ferroviário Claudino José da Silva era, ao lado de Sabença, outro deputado eleito pelo PCB no Rio de Janeiro. Como aprendiz de carpinteiro, integrou a diretoria do Centro de Carpinas e Classes Anexas de Mar e Terra da capital até que, em 1928, ingressou na Liga Operária da Construção Civil de Niterói e filiou-se ao PCB, sendo eleito, pouco depois, primeiro-secretário da entidade. Após a greve da Estrada de Ferro Leopoldina, foi escolhido delegado da Confederação dos Trabalhadores do Brasil (CTB) ao congresso da União dos Trabalhadores em Pernambuco, realizado no Recife, quando foi preso pela primeira vez por participar de reuniões sindicais. Libertado, mudou-se para João Pessoa (PB), onde continuou a atuar no PCB. Foi detido várias vezes, até ser deportado para Recife e, depois, para o Rio de Janeiro. Depois de várias outras prisões, foi condenado a dois anos em regime fechado. Libertado em 1943, passou a compor o grupo que formava a CNOP, com vistas à reorganização do partido. Na Conferência da Mantiqueira foi eleito ao Comitê Central Nacional do partido. Em 1945 foi o único negro eleito à Assembleia Nacional Constituinte com 11.231 votos (MEDEIROS, 2014, p. 31).

O deputado mais votado do PCB nas eleições de dezembro de 1945 foi o paraense José Maria Crispim. Eleito aos 34 anos, Crispim começou a trabalhar como servente de pedreiro aos 12 anos de idade. Também exerceu as profissões de aprendiz de alfaiate e comerciário. Após transferir-se para o Rio de Janeiro, concluiu o curso de Monitor de Educação Física no Exército e alcançou a patente de Sargento de Artilharia na guarnição da Vila Militar do Rio de Janeiro, quando se filiou ao PCB, em 1935. Preso logo após o levante comunista daquele ano, foi libertado dois anos depois, passando a organizar clandestinamente o PCB em São Paulo entre 1937 e 1941. Preso novamente, foi duramente torturado na prisão, tendo sido, em seguida, transferido para o presídio da Ilha Grande (RJ), onde permaneceu na condição de preso político até ser anistiado em 1945. No contexto da democratização, foi eleito Secretário do Comitê Municipal do $\mathrm{PCB} / \mathrm{SP}$, tendo sido, ainda, várias vezes preso mesmo após a anistia. Foi eleito com expressivos 36.657 votos, maior votação de um deputado do PCB depois de Prestes (BRAGA, 1998, p. 720) 
A bancada formada por Bezerra, Claudino, Batista Neto, Oliveira, Fernandes, Sabença, Pacheco e Crispim era a outra face da bancada até hoje mais conhecida do PCB na Assembleia Constituinte de 1946 e composta por nomes como Prestes, Jorge Amado e Marighella. Além de comprovar a forte presença do PCB junto aos setores operários e militares, o pouco interesse demonstrado pela historiografia pela atuação destes homens demonstra também como a dinâmica da institucionalidade pode ofuscar as classes subalternas, mesmo que estejam estas em condição de igualdade formal em relação aos demais personagens da história do PCB. Além disso levanta uma questão de fundo, a saber: a existência de "duas bancadas" tão diferentes dentro da bancada comunista na Assembleia Constituinte teve alguma repercussão na atividade parlamentar do partido? Ou simplesmente expressa uma dinâmica interna do PCB e sua defesa dos intelectuais revolucionários bem como sua vinculação a determinado arquétipo de dirigente comunista?

\subsection{Duas bancadas em uma?}

Como fica claro através da documentação oficial, a bancada comunista foi bastante ativa. Ao todo, o PCB apresentou 180 emendas ao texto da Constituição, muitas delas aprovadas. Porém, a atuação de cada parlamentar, seja nos debates, seja nas proposições legislativas, foi bastante diferente uma das outras. Como veremos, há duas bancadas em uma: uma bancada mais atuante, responsável pela maioria das emendas do PCB ao projeto de Constituição, que participou das principais Comissões e realizou a maioria dos discursos e encaminhamentos em nome dos comunistas, formada pelos intelectuais e pelos deputados oriundos das classes médias. Outra bancada mais discreta e menos atuante, formada pelos deputados de origem operária.

Segundo o estudo de Sérgio Soares Braga (1998), dos quinze constituintes efetivos, oito eram ou haviam sido trabalhadores manuais ${ }^{52}$ : Batista Neto (operário), Agostinho de Oliveira (ferroviário e operário), Gregório Bezerra (camponês e sargento do Exército), Abílio Fernandes (metalúrgico), Alcides Sabença (metalúrgico e carpinteiro), Osvaldo Pacheco

\footnotetext{
${ }^{52}$ Basicamente aquelas profissões socialmente qualificadas como tendo baixo nível de qualificação de educação formal, como operários, estivadores e camponeses. Ao analisar a ocupação das instâncias de direção do PCB, Leôncio Martins Rodrigues também explora a origem social de seus membros, oferecendo hipótese diversa da nossa, como se verá adiante. Ademais, na divisão proposta por ele, os militares, independente de formação ou patente, são considerados por ele como parte de determinada elite que se contrapõe aos dirigentes de origem operária. Ao contrário dele, nossa divisão - inspirada em Sérgio Soares Braga - separa os militares do PCB por patente e origem, chegando a um resultado diferente daquele encontrado em Rodrigues. Para mais informações cf. RODRIGUES, L. M.. "O PCB: Os dirigentes e a organização". In: FAUSTO, B. (Dir.). História Geral da Civilização Brasileira. Rio de Janeiro: Bertrand Brasil, 1997, volume III, tomo 10.
} 
(estivador), José Crispim (pedreiro, alfaiate e sargento do Exército) e Claudino Silva (ferroviário e carpinteiro). O restante da bancada era formado por dois jornalistas (Carlos Marighella e Maurício Grabois), um escritor e advogado (Jorge Amado), dois médicos (Alcedo Coutinho e Milton Caires de Brito), um contador e desenhista técnico (João Amazonas) e um engenheiro militar (Prestes). Apesar dessa divisão, a bancada comunista era, sem sombra de dúvida, a que melhor representava - ainda que de forma bastante desproporcional - os vários extratos da sociedade brasileira da época. Para termos um panorama do perfil da bancada comunista em relação às demais, tomemos como referência a bancada do PSD. Entre os senadores e deputados eleitos por aquele partido, havia 10 banqueiros, 19 industriais, 43 proprietários de terras, 28 advogados, além de vários médicos, engenheiros, jornalistas e professores universitários, dentre outras profissões. Portanto, a bancada comunista se diferia das demais não apenas por suas propostas, mas também pela origem social de seus membros (BRAGA, 1998, p. 132).

A hipótese da existência de "duas bancadas" que se distinguiam pelo papel que desempenhavam no transcurso da Assembleia Constituinte pode ser observada a partir de alguns dados disponibilizados pela Câmara dos Deputados. A composição das Comissões e Subcomissões, por exemplo, confirma esta hipótese. Na mesa da Assembleia Constituinte, espaço mais expressivo ocupado pelos comunistas, o representante do partido foi o jornalista Carlos Marighella ( $2^{\circ}$ Suplente de Secretário). Além disso, todos os deputados da "bancada dos intelectuais" estavam representados nas dez comissões e subcomissões nas quais o PCB teve assento. Entre os deputados da "bancada operária", composta por oito parlamentares, quatro não integravam nenhuma Comissão: Gregório Bezerra, Abílio Fernandes, Alcides Sabença e o único deputado negro da Constituinte, o ferroviário Claudino José da Silva. Prestes, embora formado em engenharia, tinha também uma formação militar, guardando características próprias e distintas tanto das profissões especializadas quanto das atividades manuais. Como líder da bancada, o único senador do partido não participou de nenhuma Comissão, privilegiando a atuação no plenário da Assembleia Constituinte.

Outro dado que demonstra a diferença de atuação no interior da bancada comunista está na apresentação de emendas. Das 180 emendas do PCB à Constituição, 123 foram apresentadas pelos deputados "intelectuais" e apenas 47 emendas foram apresentadas pelos deputados operários. Caires de Brito (23 emendas), Marighella (19 emendas), Amazonas (17 emendas), Grabois (17 emendas), Alcedo Coutinho (17 emendas) - todos eles juntos apresentaram o maior número de emendas. Em contrapartida, Gregório Bezerra (6 emendas), Claudino Silva (5 emendas), Alcides Sabença (4 emendas), Agostinho de Oliveira (5 
emendas) e Abílio Fernandes (1 emenda) - os deputados que menos emendas apresentaram eram todos da "bancada operária" 53 . Notamos, portanto, uma diferença visível na atuação dos deputados oriundos dos setores médios e daqueles oriundos dos setores populares. Aqui, a divisão entre trabalho intelectual e manual tomou uma dimensão simbólica, constituindo uma verdadeira divisão social do trabalho político na bancada do PCB.

A dificuldade dos deputados de origem operária era natural num espaço em que os procedimentos formais tinham considerável valor. Além disso, havia toda uma liturgia a que os comunistas estavam pouco habituados - mesmo os deputados que aqui consideramos "letrados". Num relato sincero, Gregório Bezerra descreve as dificuldades enfrentadas por aqueles lutadores sociais, em um espaço absolutamente hostil aos comunistas, tanto na forma quanto no conteúdo:

\begin{abstract}
As minhas atividades na Assembleia Nacional Constituinte na elaboração da Constituição da República de 19 de setembro de 1946 foram, em linhas gerais, modestas. Isso porque não era possuidor de uma cultura à altura do cargo de constituinte, como também pelo acúmulo de tarefas partidárias e de massa que caíram sobre os meus ombros. Todavia, ajudado pela bancada comunista e pelo partido, pude desempenhar minhas funções, não como desejava, mas como me foi possível (BEZERRA, 1979, p. 358).
\end{abstract}

A modéstia de Bezerra, uma das muitas qualidades presentes nos relatos dos que com ele conviveram, não permitiu que ele percebesse que sua atividade parlamentar foi, dentre seus camaradas da "bancada operária" do PCB, uma das mais ativas, com diversos pronunciamentos e um ativo engajamento em causas importantes. Outro exemplo que ilustra bem as dificuldades dos deputados operários na Constituinte é o do líder ferroviário Claudino José da Silva. Único deputado negro entre os 338 parlamentares, Claudino foi um dos deputados comunistas menos ativos. Ao todo, sua atividade resume-se à apresentação de cinco emendas à Constituição, quatro requerimentos, dois pronunciamentos e quatro apartes. Os discursos de Claudino, realizados nos dias 13 de fevereiro e 15 de março, versavam, respectivamente, sobre a atuação da Força Expedicionária Brasileira (FEB) na Segunda Guerra Mundial e sobre a situação dos negros no Brasil, a partir da homenagem prestada pela

\footnotetext{
${ }^{53}$ Os dados referentes à quantidade de emendas apresentadas por cada deputado foram extraídos do estudo de Braga (1998). Na somatória das emendas apresentadas, porém, o autor afirma que a bancada apresentou um total de 180 emendas. Somando as emendas individuais de cada parlamentar, porém, o número de emendas atinge apenas 170. A divisão das emendas por cada uma das "bancadas" do PCB e a tese de uma divisão social da atuação parlamentar é apresentada, pela primeira vez, em minha monografia de conclusão do Bacharelado em História. Para saber mais: cf. MEDEIROS, J. Das profundezas da História: Um comunista negro na Assembleia Nacional Constituinte de 1946. Monografia. (Bacharelado em História) - Universidade de Brasília, Brasília, 2013.
} 
Assembleia Constituinte à memória de Duque de Caxias e da Princesa Isabel, por ocasião do $59^{\circ}$ aniversário da abolição da escravidão. As descrições do primeiro discurso do único deputado negro da Constituinte dão conta de que Claudino levou muito tempo para concluí-lo e o fez com dificuldade. Expressando as visões dos jornais da época, o diário O Estado de São Paulo atacou o parlamentar afirmando que:

O orador ocupou a tribuna por um tempo excessivo, e lia imperturbavelmente, atrapalhava-se na leitura, cometia silabadas a todo instante. [...] O orador comunista, um autêntico popular e crioulo, cumpriu o seu dever partidário até o fim, apesar dos tropeços na leitura, cujo texto era rebarbativo, mesmo para letrados, tal o jargão em que estava escrito (NETTO, 1985, p. 94).

Sobre o mesmo episódio, o jornalista Mário Magalhães afirma:

\begin{abstract}
Ele não era autor daquele arrazoado, como se davam conta até as pastilhas que desenhavam no chão do prédio alguns dos mosaicos mais coloridos do Rio. Um dos quinze componentes da bancada comunista, Claudino recebera ajuda dos dois redatores que socorriam os camaradas de intimidade escassa com as letras. Sentado num canto da mesa que dirigia a sessão, um deles, Carlos Marighella, piscava para o outro, Jorge Amado, acomodado com os correligionários no flanco esquerdo do plenário. Celebravam duplo triunfo.

O primeiro era fazer do único negro retinto entre os 328 Constituintes o orador da intervenção mais longa. Claudino era alto como um poste, magro feito um palito e de uma cor que, no período em que trajou ternos e sapatos brancos, rendeu-lhe entre os camaradas o apelido de lápis - sua cabeça sugeria a ponta do grafite. [...] Contra ou a favor, ninguém se lembraria de falação mais demorada. O outro propósito foi constranger os adversários: receosos de insinuações de racismo, eles não escapuliriam para a sala do café (MAGALHÃES, 2012, p. 166-167).
\end{abstract}

A reconstituição da cena, embora dispondo de recursos narrativos próprios do jornalismo, permite-nos perceber duas características principais daquele primeiro pronunciamento: as dificuldades dos deputados operários com alguns ritos da Assembleia Constituinte e o racismo velado para com o único negro da Câmara dos Deputados.

Há pelo menos mais dois episódios que atestam uma flagrante ingerência das instâncias de direção em favor dos deputados "letrados". O primeiro é a já mencionada renúncia do ferroviário Márcio Scott, forçada pelo Comitê Regional de São Paulo. De acordo com informações do Tribunal Superior Eleitoral, Scott alcançou 13.570 votos contra os 10.595 do primeiro suplente, Milton Caires de Brito, dirigente do Comitê Central e da Comissão Executiva Nacional, que ascendera com a geração que tomou parte na reorganização do partido, em 1943 (BRASIL, 1950, p. 41). O segundo episódio refere-se a outra renúncia, mas, dessa vez, por um período de tempo menor. Entre 18 de março e 18 de 
junho, durante quase metade de toda a Constituinte, o deputado Abílio Fernandes, deputado operário da bancada gaúcha do PCB, licenciou-se dos trabalhos da Assembleia. Em seu lugar assumiu André Trifino Correia, um ex-comandante da coluna Prestes que lutara sob as ordens de Siqueira Campos, durante o movimento tenentista entre 1924 e 1927. Preso por diversas vezes e torturado no Estado Novo, Trifino optou pelo exílio, retornando ao Brasil e ingressando no PCB apenas após a anistia (BRAGA, 1998, p. 592). Apesar do impressionante currículo, é no mínimo estranho que um deputado comunista da importância de Abílio Fernandes (também, à época, secretário do partido no Rio Grande do Sul), abrisse mão do seu mandato por três meses, num momento de enorme ebulição política, em favor de um suplente com pouca vivência no interior do partido - embora fosse amigo próximo do grande líder do partido. Curiosamente, mesmo sendo militar, Trifino seria mais um a atestar as dificuldades travadas pelos comunistas no ambiente da Assembleia Constituinte: numa discussão acalorada no plenário do Palácio Tiradentes, o deputado gaúcho chamaria a atenção durante os trabalhos constituintes, por ter feito o gesto de endereçar uma "banana" a Barreto Pinto (PTB/DF), quando este tomou a palavra para defender a cassação do PCB e lançar acusações contra Luís Carlos Prestes (Idem).

Podemos supor que essa divisão - que até aqui se expressa apenas como uma espécie de "divisão social do trabalho legislativo" - não tenha gerado maiores consequências na dinâmica da bancada comunista, nem divergências relevantes sobre a intervenção dos comunistas naquele espaço. Mesmo porque a disciplina e o espírito partidário sempre foram, como veremos, uma característica marcante da organização dos comunistas no período. Além disso, a julgar pela participação dos deputados operários e suas proposições, sua presença na Assembleia Constituinte aportou enorme contribuição à busca por um regime efetivamente democrático.

Entre as emendas apresentadas por deputados comunistas de origem operária, estão aquelas que preveem a autorização da Câmara dos Deputados para a mobilização das Forças Armadas pelo Presidente da República, ou ainda, aquela que proíbe a extensão dos tribunais militares aos civis em tempo de paz ou em caso de crimes contra a segurança interna. Ambas foram apresentadas por Gregório Bezerra (Ibid., p. 515). Já Claudino José da Silva apresentou a emenda $\mathrm{n}^{\mathrm{o}} 3.600$, que determinava a punição por lei de práticas de discriminação racial e propaganda de luta religiosa (Idem).

Foram da autoria de Batista Neto as emendas: $n^{0}$ 2.892, dando à União competência exclusiva para taxar os capitais das empresas e sociedades anônimas, cujos lucros atingissem mais de $10 \%$ sobre o capital investido; $\mathrm{n}^{\mathrm{o}} 3.374$, determinando a participação dos 
trabalhadores na gestão das firmas, a fim de fiscalizar a destinação da parcela do lucro a que tinham direito por dispositivo constitucional; e $\mathrm{n}^{\circ} 3.375$, proibindo o trabalho a menores de 14 anos e o trabalho noturno e em indústrias insalubres para todos os menores (Ibid., p. 292). Por sua vez, coube a José Crispim a apresentação das emendas destinadas ao título "Da Declaração de Direitos", dentre as quais a que determinava a suspensão dos direitos políticos daqueles que difundissem ideias racistas e incitassem a luta religiosa; a que assegurava a todos os cidadãos o direito de resistirem às violações de suas liberdades e de seus direitos assegurados em lei; e a que garantia amplo direito de desfile e de reunião, bem como a que extinguia o estabelecimento de censura prévia por motivo de moralidade e de bons costumes (Ibid, 722). Como vemos, o fato de comporem a parte da bancada comunista que menos intimidade tinha com o processo legislativo ${ }^{54}$, os deputados "operários" apresentaram destacada contribuição aos trabalhos da Constituinte, reforçando uma plataforma em favor da ampliação de direitos e da eliminação dos últimos resquícios do Estado Novo.

A divisão entre "letrados" e "operários", no entanto, não se circunscrevia à bancada comunista na Assembleia Constituinte. Em julho de 1946, realizou-se no Rio de Janeiro a III Conferência Nacional do PCB. Lá os órgãos de direção foram eleitos pela primeira vez na legalidade e apresentados publicamente. Para o Comitê Central (espécie de direção nacional ampliada) são escolhidos Luís Carlos Prestes, Diógenes Arruda Câmara, João Amazonas, Pedro Carvalho Braga, Celso Cabral, Milton Caires de Brito, Moisés Vinhas, David Capistrano, José Maria Crispim, Giocondo Dias, Agostinho Dias de Oliveira, José Francisco de Oliveira, Francisco Gomes, Maurício Grabois, Lindolfo Hill, Sérgio Holmos, Carlos Marighella, José Martins, João Massena, Estocel de Moraes, Mautílio Muraro, Pedro Pomar, João Sanches Segura, Amarílio Vasconcelos, Agliberto de Azevedo, Abílio Fernandes, Lourival Vilar Costa, Domingos Marques e Jorge Herlein. Nota-se que dos sete membros da chamada "bancada letrada", apenas dois deles não faziam parte do Comitê Central (Jorge Amado e Alcedo Coutinho); enquanto isso, na bancada operária a conta se inverte: dos oito membros, apenas três compõe a instância máxima de direção do partido: Agostinho Neto, Abílio Fernandes e José Crispim.

Ao verificarmos a Comissão Executiva Nacional, instância que dirige o partido no diaa-dia, veremos que dos nove membros eleitos, apenas um faz parte da bancada operária: Agostinho Dias de Oliveira. Por outro lado, Grabois, Amazonas, Caires de Brito e Prestes

\footnotetext{
${ }^{54}$ Em relação à experiência prática no âmbito do parlamento não havia diferença entre "letrados" e "operários", já que todos eram deputados em primeira legislatura. O que supomos, por razões autoexplicativas, é que os deputados "letrados" tenham enfrentado menos dificuldades no transcorrer dos trabalhos da Constituinte que aqueles oriundos do trabalho popular e sindical.
} 
garantem ampla presença dos deputados letrados no órgão mais importante do partido (VINHAS, 1982, p. 93).

Além disso, os órgãos de imprensa do partido tinham forte presença dos dirigentes "letrados". Vale destacar que a direção desses órgãos conferia enorme prestígio aos seus responsáveis, seja pela importância estratégica destes instrumentos, num tempo em que a internet e a televisão sequer existiam e em que o rádio começava a se popularizar, seja pelo elemento simbólico destas publicações na tradição comunista: tanto Marx quanto Lênin eram homens das letras e dirigiram jornais revolucionários em suas respectivas épocas e países ${ }^{55}$.

Analisando a presença dos deputados "letrados" na direção destes órgãos, encontraremos Carlos Marighella à frente da revista teórica Problemas, da qual foi diretor até 1947. Já o jornal A Classe Operária, teve como editor o jornalista Mauricio Grabois, entre 1945 e 1949. O já renomado autor de Os subterrâneos da liberdade, Jorge Amado, também ocupou funções de direção junto a um dos jornais do partido, o diário Hoje, editado em São Paulo no contexto da democratização (1945-1946). Ao seu lado, na direção daquele órgão, estava Milton Caires de Brito, que colaborou no começo dos anos 1940 com a edição da revista Continental, órgão do CNOP.

Como se nota, a presença dos deputados "letrados" não era amplamente majoritária apenas nas instâncias do partido, mas também nos órgãos que irradiavam a política formulada nessas instâncias. Além do mais, esses espaços constituíam importantes redutos de poder simbólico que, sem dúvida, faziam pender em favor dos deputados "letrados" os pratos da balança no momento de definir o papel de cada um na condução da política comunista no interior da Assembleia Constituinte. Notamos, portanto, que a divisão entre "letrados" e "operários" não surgiu na Assembleia Constituinte: ela foi "importada" de outros espaços e apenas reproduzia relações de hierarquia pré-existentes.

Mas se, como notamos, essa proclamada diferença entre "letrados e operários" (que, como todo modelo analítico, é arbitrário por natureza) não provocou dificuldades relevantes na dinâmica interna da bancada, nem prejudicou o desempenho dos deputados que foram preteridos das posições de direção nos espaços reservados ao PCB na estrutura da Constituinte, qual a sua relevância? O que, para além de relações de hierarquia baseadas em critérios exógenos à própria bancada comunista, ela tem a dizer sobre a própria natureza da organização e da política comunista?

\footnotetext{
${ }^{55}$ No caso russo, a importância é ainda maior: a cisão do Partido Operário Social Democrata Russo entre Bolcheviques (maioria) e mencheviques (minoria) se consumou na luta pelo controle do Comitê Central, mas também, do jornal do partido, o lendário Iskra - "a centelha", em russo - logo após o II Congresso do POSDR, realizado em 1903 (LENIN, 1975, p. 125).
} 


\subsection{O bolchevismo e os bolcheviques}

Conforme vimos no primeiro capítulo deste trabalho, há muitas abordagens para o estudo dos partidos comunistas. Cada uma delas responde a determinados pressupostos que carregam em si visões de mundo, da política, da democracia etc. Para Duverger, por exemplo, os partidos comunistas fariam parte dos "partidos totalitários" e, por essa razão, suas ações, funcionamento, estrutura e ideologia teriam características próprias. A proposta comunista assumiria, no esquema de Duverger, um papel central, já que ela seria a forma pela qual o partido materializaria o controle total da vida de seus membros (PANDOLFI, 1995, p. 45). Para Michels, os partidos comunistas seriam a prova cabal da "lei de ferro da oligarquização", em que as massas abrem mão de suas "escolhas racionais" para delegar o poder aos burocratas de uma organização centralizadora e antidemocrática (MICHELS, 1981).

Questionando essa perspectiva, Antônio Gramsci insiste que é preciso "separar as coisas". Um problema seria a democracia interna (ou, precisamente, a falta dela) nas organizações comunistas, fenômeno ressaltado por Michels; outro, bem diferente, é o objetivo estratégico da organização política comunista, isto é, o Estado verdadeiramente democrático (CODATO; BRAGA, 2012). E que "para conquistar a democracia no Estado pode ser necessário (ou melhor, quase sempre é necessário) um partido fortemente centralizado" (GRAMSCI, 1984, p. 108). A dificuldade aqui, como se percebe, é evidente: como garantir que essa organização "fortemente centralizada", isto é, hierárquica, desigual e excludente, fosse perseguir um fim - a igualdade - que é o exato oposto da sua natureza? Ou ainda: como exatamente uma vez no poder, essa organização antidemocrática poderá ser democraticamente controlada? (CODATO; BRAGA, op. cit.). Esse é o problema colocado por Michels e, em cujo labirinto, os marxistas se perderam por quase cem anos, ora ignorando abertamente a relação entre democracia e socialismo, ora dando respostas insuficientes, que apenas "adiavam" a solução deste conflito para o futuro.

A estrutura das organizações comunistas, sejam elas partidos ou não, responde a uma complexa relação entre meios e fins. Por isso é fundamental determinar com precisão a que organizações exatamente no referimos quando falamos de partidos comunistas. A concepção que Michels, Duverger e Gramsci têm desses partidos é aquela forjada pelo processo de "bolchevização" das organizações partidárias, afiliadas à Internacional Comunista em todo o mundo após o rompimento definitivo dos revolucionários russos com a corrente 
socialdemocrata - que hegemonizara o movimento operário na Europa até a Primeira Guerra Mundial $^{56}$. Mas suas origens remontam aos fundadores do chamado "socialismo científico".

A questão do partido ganhou relevo na obra de Marx e Engels com a publicação, em 1848, do famoso Manifesto Comunista. Nele, os fundadores do socialismo esboçam a relação entre consciência de classe organização política na forma de partido:

Às vezes os operários triunfam; mas é um triunfo efêmero. O verdadeiro resultado de suas lutas é menos o sucesso imediato que a crescente união dos trabalhadores. Essa união é facilitada pelo crescimento dos meios de comunicação que são criados pela grande indústria e que permitem aos operários de diferentes localidades tomarem contato. Ora, é suficiente essa tomada de contato para centralizar as numerosas lutas locais que em toda parte assumem o mesmo caráter numa luta nacional, numa luta de classes. [...] Essa organização do proletariado em classe e, portanto, em partido político, é incessantemente destruída pela concorrência que existe entre os próprios operários. Mas ela renasce sempre e cada vez mais forte (MARX; ENGELS, 1978, p. 21).

Ou seja, Marx e Engels não ignoravam que a luta política dos trabalhadores poderia assegurar vitórias. Mas distinguiam essas vitórias - consideradas "efêmeras" - daquelas que os trabalhadores poderiam alcançar uma vez organizados na forma de partido político. E destacavam que não bastava a condição de operários para que houvesse consciência de classe. Seria a organização do proletariado, na forma de um partido, que poderia contornar a concorrência entre os operários. Para ressaltar que o papel dos comunistas organizados em partido não significava aprofundar as diferenças existentes no seio do proletariado, Marx e Engels asseveram que:

\begin{abstract}
Os comunistas não formam um partido à parte, oposto aos outros partidos operários. Não têm interesses diferentes dos interesses do proletariado. Os comunistas se distinguem dos outros partidos operários somente em dois pontos: 1) Nas diversas lutas nacionais dos proletários, destacam e fazem prevalecer os interesses comuns do proletariado, independentemente da nacionalidade; 2) Nas diferentes de desenvolvimento por que passa a luta entre operários e burgueses, representam, sempre e em toda parte, os interesses do movimento em seu conjunto (MARX; ENGELS, 2010, p. 51).
\end{abstract}

Além da ideia de que os comunistas faziam parte de um movimento mais amplo - o movimento operário - e que nele conviviam, jamais em oposição a outros partidos socialistas, o Manifesto destacava duas características que marcaram o movimento comunista internacional até os dias de hoje: a noção de que os partidos comunistas são os representantes gerais dos interesses do proletariado, isto é, aqueles que encarnam as finalidades últimas do

\footnotetext{
${ }^{56}$ Para conhecer mais sobre o rompimento entre comunistas e socialdemocratas cf. LENIN, V. I. A falência da Segunda Internacional. São Paulo: Kairós Livraria e Editora, 1979.
} 
movimento operário - a emancipação de todos os trabalhadores e a derrota revolucionária da burguesia - e o internacionalismo proletário, princípio segundo o qual a revolução socialista só seria efetivamente vitoriosa se fosse, também efetivamente, um processo mundial.

Apesar de reivindicar que "os comunistas não formam um partido à parte, oposto aos outros partidos operários", não demorou para que o próprio Marx notasse as divergências que existiam mesmo entre aqueles que se reivindicavam defensores do proletariado e da revolução social. A própria Associação Internacional dos Trabalhadores (AIT), fundada por diversas correntes políticas em 1864 - de comunistas a anarquistas, de reformistas a cooperativistas não durou mais que treze anos, sendo dissolvida em 1876 (MUSTO, 2014, p. 21-22). Havia divergências mesmo entre Marx e aqueles que se diziam seus seguidores. Num texto célebre, Marx dirige pesadas críticas ao anteprojeto de programa que seria discutido no Congresso de Gotha e selaria a união entre dois grupos socialistas alemães - para a criação do Partido Social-Democrata alemão. O texto seria publicado apenas em 1891, com o título de Crítica ao Programa de Gotha ${ }^{57}$. Além dele, são conhecidos hoje outras polêmicas travadas entre Marx junto a seus partidários. Em carta endereçada em 1879 a Bebel, Liebknecht e Barckle, comunistas alemães, Marx e Engels criticam as influências burguesas e pequeno-burguesas sobre o partido dos comunistas na Alemanha:

Há quase quarenta anos colocamos em primeiro plano a luta de classes como força
motriz direta da História e, em particular, a luta de classes entre a burguesia e o
proletariado como mais poderosa alavanca da revolução social. Portanto, é-nos
impossível caminhar junto com pessoas que tendam a suprimir do movimento essa
luta de classes. [...]. Não podemos, evidentemente, caminhar com pessoas que
declaram aos quatro cantos que os operários são muito pouco instruídos para poder
emancipar a si mesmos, e que eles devem ser libertados pelas cúpulas, pelos
filantropos burgueses e pequeno-burgueses. Se o novo órgão do partido toma uma
atitude que corresponda às ideias destes senhores, se essa orientação é burguesa e
não proletária, não nos restará mais nada para fazer, por mais lamentável que seja,
do que debater abertamente e romper a solidariedade da qual demos prova até agora
na qualidade de representantes do partido alemão no exterior (MARX; ENGELS,
1978, p. 30).

Como se vê, apesar das várias tentativas de "uniformizar" o movimento comunista no século XX, a divergência e a diversidade de pensamento eram uma característica primitiva da teoria social que surgiu e se desenvolveu a partir da obra de Marx e Engels. Essas divergências estão na base do surgimento da corrente formada pelos comunistas bolcheviques na Rússia que, autonomizando-se em relação às vertentes originais do marxismo europeu,

\footnotetext{
${ }^{57}$ A Crítica ao Programa de Gotha revela as divergências entre Marx e a corrente liderada por Ferdinand Lassalle no processo de fusão dos socialdemocratas alemães. Para conhecer mais das críticas de Marx cf. MARX, K. Crítica do Programa de Gotha. Coimbra: Centelha, 1975.
} 
produziriam interpretações políticas e organizativas totalmente originais entre o começo do século XX e a revolução de 1917.

O marxismo na Rússia teve suas origens em pequenos grupos dispersos que estudavam as obras de Marx no final dos anos 1890. Em março de 1898, um desses pequenos grupos fundaria o Partido Operário Social-Democrata Russo (POSDR). O partido fixara seu programa em "dois tempos": um programa mínimo, composto pelas tarefas democráticoburguesas (derrubada da autocracia czarista, estabelecimento de um sistema republicano democrático, garantia de direitos mínimos, dentre os quais, a jornada de trabalho e oito horas e o fim da servidão no campo); e um programa máximo, que continha as tarefas da revolução socialista (controle de todos os meios de produção, eliminação do latifúndio, estatização do sistema financeiro e instauração da ditadura do proletariado). A revolução, para os marxistas russos, também teria duas "etapas” (BOGO, 2005, p. 130).

Como um dos principais teóricos do grupo que impulsionou o marxismo na Rússia durante os primeiros anos do POSDR, Lênin dedicou boa parte de suas reflexões iniciais ao tema da organização partidária. Entre suas principais obras do período estão: As tarefas dos socialdemocratas russos (1897), O desenvolvimento do capitalismo na Rússia (1899), Carta a um camarada (1901) e Que fazer? (1902). Nas duas últimas, ele estabelece as razões pelas quais considera necessária uma organização partidária “de novo tipo" (BOGO, op. cit.., p. 132). Em Que fazer? Lênin apresenta as diferenças entre o que ele chamava de "trabalho artesanal dos economistas e a organização dos revolucionários”. Para Lênin, a primeira tarefa dos socialdemocratas deveria ser a criação de uma organização cujos membros tivessem como profissão a ação revolucionária. Ele acreditava que a luta política da socialdemocracia era muito mais complexa que a luta por melhores condições econômicas, e que exigia um tipo especial de organização. Levando em conta as condições de repressão impostas pelo czarismo, considerava que não seria possível um movimento revolucionário sólido sem uma organização estável de dirigentes profissionais. Em Carta a um camarada apontava como problemas da socialdemocracia: "a ausência de uma preparação séria e de uma educação revolucionária (não somente entre os operários mas também entre os intelectuais)"; a "utilização excessiva e inadequada do princípio eleitoral" e o "afastamento dos operários da verdadeira atividade revolucionária" (LÊNIN, 2005, p. 138).

Enquanto amadurecia essas posições, Lênin e seus seguidores afastavam-se daquele setor que defendia um partido mais amplo e menos dependente do trabalho dos revolucionários profissionais. Esse setor, liderado por Georges Plekhanov e Julius Martov, mantinha-se fiel à tradição marxista da Europa Ocidental, cuja principal referência era o PSD 
alemão. Em ambas, porém, a centralidade dos órgãos de imprensa era gigantesca. Para Lênin, aliás, o centro dirigente do partido era o próprio Iskra, "que possui correspondentes permanentes entre os operários e está estreitamente ligado ao trabalho interno da organização" (Ibid, p. 139).

Com a divisão do POSDR entre mencheviques (minoria) e bolcheviques (maioria), ocorrida no II Congresso do partido, em 1903, Lênin e seus partidários puderam testar na prática o modelo de organização defendido em Que fazer? e outros escritos. O partido bolchevique teria dois centros dirigentes: o Órgão Central (OC) e o comitê central (CC). O primeiro deveria dirigir ideologicamente, e o segundo, prática e politicamente. Nas instâncias dirigentes deveriam estar "socialdemocratas plenamente conscientes e dedicados inteiramente à ação revolucionária" (Idem). Além disso, Lênin destacava, sobre a participação de elementos proletários nestas instâncias, que "é necessário esforçar-se de modo especial para conseguir que cheguem a ser revolucionários plenamente conscientes, profissionais e que entrem no comitê o maior número possível de operários” (Ibid, p. 140). Apesar de defender que "quanto mais limitarmos o contingente de membros de uma organização desse tipo, a ponto de incluir nela pessoas que se ocupem profissionalmente das atividades revolucionárias, mais difícil será caçar essa organização", Lênin considerava que essa dinâmica não afetaria a relação destes revolucionários com as massas operárias. Em Que fazer? ele aborda a questão de forma curiosa, ao afirmar que a classe operária “fornece, todos os anos, um número sempre maior de descontentes, que querem protestar, que estão dispostos a cooperar, naquilo que puderem, na luta contra o absolutismo". O problema, porém, seria vincular estes indivíduos descontentes à organização revolucionária. A explicação para essa dificuldade, segundo Lênin, seria a falta de dirigentes capazes de realizar esse vínculo, já que:

\footnotetext{
[nesse] tempo não há homens porque não há dirigentes, não há chefes políticos, não há talentos organizadores capazes de organizar um trabalho simultaneamente amplo e unificado, coordenado, que permita utilizar todas as forças, mesmo as mais insignificantes" (LÊNIN, 1961, p. 223).
}

Em outubro de 1917, quando os bolcheviques tomaram o poder na Rússia, derrubando o governo provisório de Alexander Kerenski - e acelerando a passagem da etapa democráticoburguesa da revolução para sua etapa socialista -, as teses de Lênin sobre a organização partidária e as formas de luta parecem comprovar-se pelos fatos. Pela primeira vez na história uma revolução socialista era vitoriosa. E o era contrariando as leituras mecanicistas do marxismo europeu, que previam que a revolução aconteceria primeiro naqueles países nos 
quais as forças produtivas estivessem mais desenvolvidas (notadamente Alemanha e Inglaterra) e que fossem lideradas por um amplo partido de massas, como o tradicional PSD alemão. A cisão entre esses pontos de vista tomaria dimensões incontornáveis com o apoio da II Internacional - composta pelos partidos socialdemocratas da Europa ocidental - à Primeira Guerra Mundial, e com a carnificina por ela produzida. Cindido o movimento operário, a máxima de Marx proclamada no Manifesto, de que "os comunistas não formam um partido à parte, oposto aos outros partidos operários”, desmanchava-se pelas condições históricas. Dali em diante, o bolchevismo seria um divisor de águas na luta pelo socialismo em todo o mundo.

A vitória bolchevique fez surgir o modelo do "partido proletário de novo tipo": protótipo que levara os trabalhadores à vitória na Rússia czarista e inaugurara a primeira experiência na história inspirada nos pressupostos teóricos do socialismo científico. Não era pouco. O "bolchevismo" transformou-se num modelo reafirmado por diferentes dirigentes soviéticos, como Trotsky, Stálin e Bukharin. Todos, ao seu modo, trabalharam em favor da glorificação da experiência bolchevique e da sua "exportação" como modelo. Em sua expressão máxima, com a morte de Lênin e com a ascensão de Stálin, o bolchevismo ganhou o sugestivo nome de marxismo-leninismo e se converteu em ideologia oficial de todos os partidos comunistas alinhados à Internacional Comunista, especialmente após a Segunda Guerra Mundial. Nos artigos que compõem a obra Fundamentos do Leninismo, publicados em 1924, Stálin afirma sobre o leninismo que:

\footnotetext{
Uns dizem que o leninismo é a aplicação do marxismo às condições peculiares da situação russa. Esta definição contém algo de verdadeiro, mas está longe de encerrar toda a verdade. É certo que Lênin aplicou o marxismo à realidade russa e o aplicou de forma magistral. Mas se o leninismo não fosse mais que a aplicação do marxismo à situação peculiar da Rússia, o leninismo seria um fenômeno pura e exclusivamente russo. E, sem dúvida, sabemos que o leninismo é um fenômeno internacional e não exclusivamente russo. Eis porque entendo que esta definição peca por unilateralidade. [...]

O que é, pois, no fim das contas, o leninismo? O leninismo é o marxismo da época do imperialismo e da revolução proletária. Ou mais exatamente: o leninismo é a teoria e a tática da revolução proletária em geral, a teoria e a tática da ditadura do proletariado em particular (STÁLIN, 1975, p. 10)
}

Como podemos perceber, Stálin transferiu para o termo leninismo os atributos até então bem pouco associados e difundidos pelo Partido Comunista da URSS como sinônimos de bolchevismo. Seu principal antagonista, Leon Trotsky, reforçaria a mesma tendência vinte anos depois. Em sua obra Bolchevismo e Stalinismo, publicada em 1937, Trotsky afirma, por exemplo, que "o marxismo encontrou sua mais gloriosa expressão histórica no bolchevismo" e que sob sua bandeira "o proletariado obteve sua primeira vitória e fundou o primeiro Estado 
operário" (TROTSKY, 1978, p. 97). Apesar de ter colaborado para difundir o "mito bolchevique" enquanto foi parte da direção do Estado soviético, analisando o processo em termos retrospectivos, duas décadas depois da revolução de outubro, é justo reconhecer que Trotsky buscou dimensionar em termos históricos o bolchevismo, circunscrevendo-o como um dos fatores responsáveis pela vitória revolucionária, mas não como o único nem como o mais importante:

\begin{abstract}
O próprio bolchevismo jamais foi idêntico à Revolução de Outubro ou ao Estado soviético que dela surgiu. O bolchevismo considerava-se como um dos fatores históricos, seu fator "consciente", fator muito importante, mas não decisivo. Nunca pecamos por subjetivismo histórico. Víamos o fator decisivo - sobre a base dada pelas forças produtivas - na luta de classes, não só em escala nacional, como também internacional (TROTSKY, 1978, p. 99).
\end{abstract}

A concepção do partido de novo tipo está presente em diversas obras produzidas pelos dirigentes bolcheviques, ora associada à noção de "bolchevismo" ora ao termo "leninismo". Ela encontrou amplo terreno para difundir-se a partir do surgimento da Internacional Comunista, organismo criado como alternativa à "traição" da antiga Internacional Socialista. Ela foi fundada no final da Primeira Guerra Mundial, num contexto em que as burguesias em toda a Europa se voltavam para o combate ao bolchevismo soviético. Seu primeiro congresso, realizado em março de 1919, em Moscou, apesar de pouco expressivo numericamente (contou com apenas 51 presentes), foi marcado pela grande euforia provocada pelos levantes revolucionários na Alemanha e na Hungria. Em julho do ano seguinte, em seu segundo Congresso, mesmo diante do revés da revolução nesses países, os bolcheviques mantinham sua esperança numa revolução mundial então iminente e transmitiam esse sentimento aos demais presentes ao evento (PINHEIRO, 1991, p. 36). Tendo como centro das discussões a questão partidária, o organismo aprovou as famosas "vinte e uma condições" para a filiação dos partidos à Internacional. As normas tinham como objetivo servir como instrumento de seleção para impedir que a IC fosse invadida por lideranças de caráter reformista ou esquerdista. Vale lembrar que, no âmbito das correntes socialistas na Europa, os bolcheviques não tinham como adversários apenas a socialdemocracia: tão logo chegaram ao poder, os revolucionários russos foram alvo de toda sorte de ataques "à esquerda" por parte de grupos, 
que não reconheciam a consigna da Ditadura do Proletariado. Enfrentando esses grupos, Lênin dedicou-lhes um livro inteiro, intitulado Esquerdismo, doença infantil do comunismo ${ }^{58}$.

As vinte e uma condições previam, dentre outras medidas, "a criação, paralelamente à organização legal, de organismos clandestinos"; a denúncia do "social-patriotismo" e do "social-pacifismo, hipócrita e falso" e a "ruptura total com os setores socialdemocratas". Em termos organizativos, as condições exigiam que "os partidos pertencentes à IC devem ser construídos com base no princípio do centralismo democrático" e "depurados periodicamente para afastar os elementos pequeno-burgueses". Além disso, os partidos desejosos de entrar na IC deveriam "sustentar sem reservas todas as repúblicas soviéticas nas suas lutas com a contrarrevolução" e "excluir do partido elementos que não aceitem as condições aprovadas pelo Congresso da IC". Por fim, asseverava que "todas as decisões do Congresso da IC e de seu Comitê Executivo são obrigatórias para todos os partidos filiados" e que "todos os partidos aderentes à IC devem modificar seu nome e intitular-se Partido Comunista" (CARONE, 2003). Como observa Edward Hallet Carr, o que aconteceu não foi a fusão de uma certa quantidade de partidos comunistas de tamanho similar, mas "a submissão de um certo número de grupos fracos (em alguns casos embrionários ou em formação) a uma organização cujo principal apoio e força de motivação era, necessária e inevitavelmente, o poder do Estado soviético" (CARR apud PINHEIRO, 1991, p. 34).

\subsection{Bolchevismo à brasileira}

Seria no mínimo estranho se o bolchevismo (ou leninismo de Stálin) ${ }^{59}$ - trazendo consigo toda a carga simbólica e teórica que descrevemos, e sendo o vetor principal do surgimento dos partidos comunistas como os conhecemos - não exercesse uma influência decisiva em todos as dimensões do PCB (cultural, organizativa, simbólica, programática, retórica etc.). Fundado em 1922, o partido demorou a assimilar os preceitos fundamentais do marxismo. Na primeira década de existência, o estudo sistemático das obras de Marx e Lênin é restrito, inclusive, pela edição no Brasil de apenas dois livros de Lênin e um de Bukharin, até o fim da década de 1920, além do Manifesto Comunista. Somente aqueles militantes que

\footnotetext{
${ }^{58}$ Para conhecer a crítica de Lênin aos grupos esquerdistas europeus, notadamente holandeses, italianos e alemães, cf. LÊNIN, V. I. Esquerdismo, doença infantil do comunismo. São Paulo: Editora Anita Garibaldi, 1999.

${ }^{59}$ Sobre a relação entre stalinismo e leninismo cf. MORAS, João Quartim de. "A influência do leninismo de Stálin no comunismo brasileiro". In: História do Marxismo no Brasil. Volume II. Campinas: Editora da Unicamp, 2007b.
} 
conseguem ter acesso a obras editadas em outros idiomas é que têm condições de aprofundar seus estudos. É o caso de Octávio Brandão e Astrojildo Pereira (MORAES, 2007, p. 138). Bastante influenciado pela leitura de Fundamentos do leninismo, de Stálin, Brandão será o primeiro a utilizar o termo "marxismo-leninismo" numa publicação brasileira, o já mencionado ensaio Agrarismo e Industrialismo, publicado em 1924.

O termo marxismo-leninismo, no entanto, só passou a ser usado em documentos oficiais na URSS a partir de 1931, o que sugere que a "bolchevização" dos partidos comunistas é anterior à "canonização" da obra de Lênin e, portanto, mais vinculada às "vinte e uma condições" impostas pela IC. Ora, se o ponto de largada para a uniformização dos partidos comunistas à imagem e semelhança de seu homônimo soviético foi, como sustentamos, o II congresso da Internacional Comunista e a aprovação das "vinte e uma condições", logo, o processo de bolchevização começou quando Lênin ainda era o principal líder do partido em atividade, e respondia às necessidades de defesa da nascente república dos sovietes.

No caso do PCB, esse processo encontrou um partido com pouco acúmulo teórico, portanto, facilmente incorporável à dinâmica imposta pela IC. Ressalte-se ainda o ingresso de Prestes e de parte do movimento tenentista no partido e a depuração levada a cabo no final dos anos 1920, o que significou quase uma "refundação" do PCB no começo dos anos 1930 e uma substantiva perda de densidade programática ${ }^{60}$. Após o levante de 1935 e a reorganização de 1943, o PCB que emergiu para vida legal estava completamente "stalinizado". Não apenas pela retórica, que evocava os feitos do "guia genial dos povos", ou pela plena assimilação do "etapismo", enquanto estratégia para a construção do socialismo no Brasil, mas, sobretudo, pelo modelo partidário adotado. Sob todos os pontos de vista, o PCB se enquadra perfeitamente no padrão dos partidos comunistas forjados pela Internacional Comunista. Mas que padrão seria esse, afinal?

Daniel Aarão Reis Filho, em sua tese de doutorado, publicada em 1990 com o título $A$ revolução faltou ao encontro - os comunistas no Brasil, oferece uma interpretação um tanto

\footnotetext{
${ }^{60}$ Não é objeto deste trabalho aprofundar o nível de densidade programática do PCB, em relação às formulações oferecidas pela Internacional Comunista para a interpretação da América Latina, nem aferir o grau de dependência dos comunistas brasileiros em relação a essas formulações. Consideramos preliminarmente, analisando a bibliografia consultada, que o PCB se situava num esforço de dialética de conjugar assimilação (dos preceitos da IC) e interpretação autônoma (da realidade brasileira). Para aprofundar no tema, cf. PINHEIRO, P. S. Estratégias da Ilusão: a revolução mundial e o Brasil (1922-1935). São Paulo: Companhia das Letras, 1991 - que acentua as tendências de dependência em relação à IC - e cf. DEL ROIO, M. "O impacto da Revolução Russa e da Internacional Comunista no Brasil". In: MORAES, J. Q. de (org.). História do Marxismo no Brasil. vol. I. Campinas: Editora da Unicamp, 2007, que destaca os aspectos de autonomia em relação à IC.
} 
original sobre a natureza das organizações de esquerda que atuaram na luta armada contra a Ditadura Militar entre 1964 e 1970. Buscando interpretar as razões da "derrota" sofrida pela esquerda revolucionária, que aderiu à guerrilha urbana e rural naquele período, Reis Filho sustenta uma polêmica hipótese: as tendências antidemocráticas características daqueles agrupamentos, embora tenham agido como fatores de coesão, indispensáveis para o fortalecimento das organizações comunistas, enfraqueceram a capacidade dos comunistas de manterem contato com o processo histórico (REIS FILHO, 1990, p. 183). Os fatores determinantes que levaram ao fracasso da luta armada não resultariam, portanto, de "erros de avaliação" ou "debilidades" presentes naquelas organizações, mas da própria natureza daqueles agrupamentos: a legitimação permanente dos modelos internacionais, a dinâmica antidemocrática, a tensão máxima a que são submetidos propositalmente seus militantes e a presença marcante das elites sociais intelectualizadas, concorreriam para colocar os comunistas numa "esfera autônoma e em posição de superioridade" em relação às massas (Ibid, p. 185).

A essa controversa interpretação se opõe a obra de Marcelo Ridenti, O Fantasma da Revolução Brasileira, editada em 2005. Nela, Ridenti questiona as conclusões de Reis Filho sobre a relação entre a natureza das organizações armadas, que lutavam contra a Ditadura Militar, a derrota de sua luta pela derrubada do regime e a instalação de um sistema socialista. Destaca, ainda, os limites da hipótese sustentada pelo historiador carioca:

\begin{abstract}
No fundo, a análise de Daniel Reis Filho é o reverso daquela feita, corrente e reiteradamente, pelas autocríticas das organizações de esquerda: para estas, as vanguardas são sempre responsabilizadas pelas derrotas políticas, atribuídas a "erros" e "desvios" das próprias organizações; para Daniel Reis Filho, no entanto, as derrotas seriam atribuíveis às mesmas razões que levaram às vitórias em outras circunstâncias, noutros países: os fatores coesionadores $\left[{ }^{61}\right]$ internos das organizações comunistas de quadros, clandestinas. Nos dois casos, o centro da análise encontra-se deslocado, não está onde deveria estar (no movimento contraditório do social); mas na vontade e na atuação das supostas vanguardas. Pela tese de Reis Filho, como poderia a dinâmica interna das organizações comunistas ser compatível com aquela da luta de classes e da própria revolução? Só por mera coincidência história; a tese não oferece elementos para essa possível compatibilidade (RIDENTI, 2010, p. 253).
\end{abstract}

Assim, a dinâmica interna das organizações comunistas é pensada por Reis Filho como algo "exterior e diferente do movimento da luta de classes", como se este fosse totalmente autônomo em relação à forma como se organizam as vanguardas de esquerda. Como, então, explicar o fato de que algumas dessas vanguardas tenham, eventualmente, "encontrado" a

\footnotetext{
${ }^{61}$ Do espanhol, cohesionar, está relacionado a fatores que produzem coesão.
} 
revolução? Apenas por uma feliz coincidência histórica que uniu os comunistas a seu objetivo (RIDENTI, 2010, p. 253). Ao invés de perceber a organização e a ação dos grupos de esquerda em luta contra a Ditadura Militar como parte do movimento vivo da sociedade, Reis Filho considera tais grupos como politicamente isolados em seus princípios e vinculados a um “projeto histórico com vida própria” (REIS FILHO, 1990, p. 13). No entanto, como destaca Ridenti, os mecanismos de coesão interna das organizações descritos por Reis Filho devem ser levados em conta para demonstrar, paradoxalmente, uma tese oposta a dele: "em vez de permitir a sobrevivência das organizações comunistas sem qualquer sintonia com o movimento da luta de classes, a lógica interna das organizações torna-se autodestrutiva ao permanecer desenraizada socialmente" (RIDENTI, 2010, p. 255).

Nossa análise da história do PCB - como organização inspirada no "bolchevismo" nos leva à conclusão semelhante. Como veremos, foi precisamente quando buscou tornar-se um partido de massas que o PCB se vinculou mais fortemente à dinâmica real da luta de classes, relativizando o peso dos elementos de coesão - a estrutura leninista de organização para a ampla maioria de seus membros. Não obstante, se a crítica de Ridenti nos parece pertinente, uma vez que associa de forma mais precisa a relação entre meios (a forma de organização) e fins (a relação desta organização com um programa e uma forma de ação), não devemos deixar de reconhecer os méritos do modelo de análise proposto por Reis Filho, para compreender a estrutura das organizações comunistas tipicamente leninistas. A despeito de, segundo afirma Ridenti, “o modelo analítico proposto por Reis é [ser] mais bem aplicável, descritivamente, às organizações rigidamente estruturadas nos moldes 'marxistas-leninistas' (e stalinistas) como o PCB da época de Prestes", não podemos desconsiderar a contribuição dada por seu modelo analítico ao entendimento da natureza do que ele chama de "organizações de estado-maior". Também como Ridenti, acreditamos que o modelo proposto por Reis Filho é perfeitamente aplicável à análise do PCB dos anos 1940, já que, conforme vimos anteriormente, o partido havia concluído plenamente seu processo de "bolchevização" ao entrar na cena política legal. Para testar essa hipótese, descrevemos, de modo sucinto, os quatro fatores de coesão das organizações comunistas que dão base à formação das “organizações de estado-maior” (REIS FILHO, 1990, p. 653):

a) os mitos fundadores, tais como a inevitabilidade histórica da revolução socialista, a missão redentora do proletariado industrial e a imprescindibilidade do partido de vanguarda;

b) a dinâmica excludente e antidemocrática das organizações comunistas que se veem como elites políticas as quais detêm as "chaves do conhecimento" da história da humanidade; 
c) a estratégia da tensão máxima, composta de mecanismos que buscam assegurar coesão e disciplina ao corpo de indivíduos dedicado integralmente ao projeto revolucionário;

d) o papel das elites intelectualizadas, que comandam e constituem majoritariamente as organizações comunistas, especialmente em seus postos de direção.

Como demonstrou Ridenti, esse modelo analítico é apenas em partes válido para as organizações comunistas dos anos 1960 e 1970, já que muitas delas contestavam o papel organizacional do partido leninista clássico (RIDENTI, 2010, p. 256). No caso do PCB, organização tipicamente forjada nos moldes da Internacional Comunista dos anos 1930, o modelo analítico encontra o arquétipo perfeito.

Em primeiro lugar, os mitos fundadores funcionavam com perfeição. O PCB confiava plenamente - segundo atestam centenas de documentos oficiais - que a revolução esperada e inevitável seria promovida pelo proletariado, tal como vaticinara Marx em seu Manifesto Comunista, quase um século antes. A missão histórica da classe trabalhadora também seria celebrada nos textos de Stálin, incluindo seu "dever" de fazer a revolução mesmo onde a maioria do proletariado ainda não houvesse compreendido seus benefícios (REIS FILHO, 1990, p. 111). Para garantir o cumprimento da profecia revolucionária revelada pela análise científica da realidade e, portanto, dos processos históricos desvendados pela teoria, um partido de vanguarda seria indispensável. A combinação entre a teoria e a vinculação com os interesses da classe operária distinguiria os comunistas como um "agrupamento de elite" que, conhecendo a dinâmica do processo histórico, estaria apto a liderar os trabalhadores à redenção de toda a humanidade (Ibid, p. 113). Na História do Partido Comunista da URSS, obra de grande impacto sobre várias gerações de comunistas brasileiros e redigida sob a coordenação de Stálin, a supremacia do partido e o papel da vanguarda revolucionária são descritos como parte indispensável para o sucesso da revolução, impensável sem seu partido (Ibid, p.114). Essa compreensão explica o desprezo dos comunistas pelas demais organizações de esquerda, especialmente no período em que hegemonizaram o movimento operário após sua legalização em 1945.

Em segundo lugar, a estrutura altamente verticalizada, cuja ascensão dependia de múltiplos fatores que excluíam dessa possibilidade a maioria dos militantes comunistas, também é uma forte característica do PCB dos anos 1940. Uma vez considerada a organização que detém as chaves do conhecimento histórico - o materialismo dialético de Marx e a teoria da organização partidária de Lênin -, o partido comunista criará mecanismos mais ou menos rígidos para a adesão de novos militantes a suas fileiras. Embora o ingresso do maior número possível de indivíduos fosse considerado desejável, os critérios estipulados em cada período 
para a filiação ao partido - e desde sempre pela observância do caráter excepcional da organização comunista - acabaram por determinar o ritmo, o perfil e as formas de expansão indicados por suas instâncias de direção. Além disso, definidos os órgãos superiores do partido em seus fóruns de eleição, os militantes de base deviam seguir rigorosamente as decisões oriundas de tais órgãos, segundo o princípio do centralismo democrático, a partir do qual todos defendiam em uníssono as posições da maioria, uma vez concluído o período de discussão sobre determinado tema. E para ascender a esses órgãos de direção, o indivíduo deveria destacar-se como o melhor entre os melhores, demonstrando conhecimento da teoria revolucionária, liderança, firmeza e, de perferência, presença junto a algum trabalho de massas. Como destaca Reis Filho, o sentido antidemocrático e excludente dessa dinâmica era apenas, entre os comunistas, uma extensão, um desdobramento - e uma confirmação - de seu caráter de elite, que decorria de suas opções políticas e teóricas e que fazia parte de sua condição de vanguarda histórica (REIS FILHO, 1990, p. 142).

Em terceiro lugar, era largamente utilizada aquela que Reis Filho descreveu como estratégia da tensão máxima: conjunto de mecanismos de coesão que atingem, sobretudo, os níveis inferiores da organização partidária, tais como o "complexo da dívida", o "leque das virtudes", o "massacre das tarefas", a "celebração da autoridade" e a "ambivalência das orientações".

O chamado "complexo da dívida" é descrito por Reis Filho como o mecanismo que inferioriza o militante diante do partido e coloca-o em débito eterno para com a organização. Ao ingressar no partido, o indivíduo viverá sensações inebriantes de superioridade, uma vez que passou a fazer parte de uma elite política que tem as chaves da revolução socialista e da libertação da humanidade. No entanto, o lembrará sempre que essa superioridade é decorrente única e exclusivamente da força do Partido. Por isso, a noção de débito permanente para com a organização assumirá a forma de um "complexo": o militante, limitado e inexperiente, cheio de "vícios" e "desvios" encontrará no partido o manancial de conhecimento e experiência prática que o permitirá transformar-se num "homem novo" (Ibid, p. 120). Por isso a centralidade da formação política e do estudo teórico nas organizações comunistas. O "leque das virtudes" é a outra face deste processo de formação do "homem novo" após o ingresso do indivíduo no partido. Para saudar a dívida para com a organização, o militante deve cultivar as mais belas qualidades, de acordo com os valores superiores representados pela causa comunista: simplicidade, dedicação, firmeza, disciplina, modéstia, devotamento. Em dezembro de 1967 o PCB chegou a listar essas qualidades em seus novos estatutos (Ibid, p. 122). Elas deveriam ser demonstradas no cumprimento das tarefas partidárias, tais como o 
estudo teórico, o debate político sobre a linha política do partido em espaços coletivos de reunião, o trabalho nas frentes de massas, a agitação e a propaganda revolucionárias, etc. Tarefas internas e externas que consumiriam o tempo e a dedicação intelectual de todos os militantes, independentemente da posição que ocupassem no interior do partido. É o massacre das tarefas de que fala Reis Filho em sua obra (Ibid, p. 124).

Outro mecanismo de coesão importantíssimo e fortemente presente nos partidos comunistas é a chamada “celebração da autoridade". No PCB essa celebração deu-se em torno da carismática figura de Luís Carlos Prestes, mas começara bem antes, com o culto a Marx e Engels, os "pais fundadores" do socialismo científico, passando por Lênin e Stálin. Outros partidos e organizações reproduziram - e reproduzem - esse culto, não apenas aos fundadores do marxismo, mas também em expressões de menor vulto, como Trotsky e Rosa Luxemburgo. Com o fracionamento do movimento comunista internacional a partir da crise sino-soviética ${ }^{62}$, outros heróis foram introduzidos no panteão dos grandes revolucionários do século XX, como Mao Tsé Tung, Ho Chi Min, Che Guevara e Fidel Castro. Esses nomes encarnariam o símbolo do líder comunista: conhecimento teórico, capacidade organizativa, espírito de sacrifício e altos valores morais. No caso de Prestes, os comunistas souberam disseminar a imagem do "cavaleiro da esperança". Segundo Reis Filho, o recurso à celebração da autoridade "unifica a organização, fornece uma fonte viva de argumentos de autoridade, cria um arquétipo referenciador - teórico, político, moral, que dirime, eventualmente, dúvidas, divergências, decide e dá a última palavra nas crises” (REIS FILHO, 1990, p. 130).

Outro forte elemento de coesão estaria na ambivalência das orientações políticas. Se, por um lado, posições pouco claras provocam dúvidas e instauram confusão, por outro, acomodam mais facilmente divergências. No PCB pós-1945 essa talvez seja, como veremos, uma das características mais marcantes de seu discurso. Como destaca Reis Filho, nem a participação da burguesia nacional na revolução brasileira, posição defendida ardorosamente pelos comunistas após sua legalização, escapa de ambiguidades. Se ora o PCB descreve a burguesia como "objetivamente revolucionária" (posto que o Brasil guarda ainda resquícios feudais), em seguida alerta para sua subordinação e cumplicidade para com o imperialismo. Chegou-se a falar numa aliança "com e contra a burguesia" (REIS FILHO, 1990, p. 131).

\footnotetext{
${ }^{62}$ A crise sino-soviética caracterizou-se pelo rompimento das relações políticas e diplomáticas entre a República Popular da China (governada pelo Partido Comunista Chinês) e a União Soviética, entre o final da década de 1950 e início dos anos 1960. Essas tensões chegaram a alcançar a forma de conflito armada entre os exércitos dos dois países em março de 1969.
} 
Por fim, o último elemento que compõe a chamada estratégia da tensão máxima é a síndrome da traição. Uma vez vinculado ao partido, o indivíduo estabelece uma relação com determinados postulados que transcendem a própria organização: está vinculado a um projeto de humanidade. O seguinte caso é ilustrativo: quando Octávio Brandão perdeu seu mandato de vereador na cidade do Rio de Janeiro, em 1948, foi em seguida preso, torturado e caiu na clandestinidade. Vivendo com extremas dificuldades, não fez mais que queixar-se, afirmando que "há mais de seis anos vivo das esmolas dos amigos, sem tarefa nem ligação com o PC, completamente abandonado, num desconforto atroz - físico, moral e intelectual”. Apesar disso, Brandão jamais mencionou a possibilidade de rompimento com o PCB. Em momentos de crise, um comunista dificilmente questionava o ideal de revolucionar o mundo ou o partido organizado sob os princípios do "leninismo" (FERREIRA, 2002, p. 278). Aquele que opta pelo rompimento com o partido será considerado um traidor, um inimigo que enfraquece a luta e que, “objetivamente”, faz o jogo dos inimigos do povo (REIS FILHO, 1990, p. 134).

O quarto e último fator de coesão das organizações de estado-maior seria sua composição social. Segundo Reis Filho, analisando as organizações da esquerda armada dos anos 1960 e 1970, a partir dos dados disponíveis no projeto Brasil Nunca Mais ${ }^{63}$, nota-se uma expressiva presença de trabalhadores intelectuais entre torturados, mortos e processados. Aqui a transplantação mecânica dos dados analisados nos anos 1960/70 para a realidade de 1945 pode resultar enganadora. Em primeiro lugar, porque a esquerda armada que se engajou na luta contra a Ditadura Militar era formada por grupos com baixa influência de massas e, assim, pouca capacidade de vincular-se ao trabalho operário - inclusive pelas condições impostas pela clandestinidade. Por sua vez, relatos da época dão conta de que o PCB em 1945 pode ter chegado a algo em torno de 200 mil filiados e tinha entre seus quadros artistas e intelectuais como Portinari, Di Cavalcanti, Lazar Segall, Oscar Niemeyer, Graciliano Ramos, Carlos Drummond de Andrade, Oswald de Andrade, dentre outros (KONDER, 2004, p. 67). Era, portanto, um partido de massas em construção. No entanto, um dos elementos apontados por Reis Filho como fortemente influenciado pela presença de setores sociais intelectualizados, e que é comum tanto às organizações dos anos 1960/70 quanto ao PCB de 1945, é a permanente defesa dos intelectuais revolucionários. Para Lênin, a perspectiva revolucionária - isto é, a passagem da consciência sindical-corporativa à consciência de classe

\footnotetext{
${ }^{63} \mathrm{O}$ projeto Brasil: Nunca Mais reuniu um grupo de especialistas que se dedicou durante 8 anos a reunir cópias de mais de 700 processos políticos que tramitaram pela Justiça Militar entre abril de 1964 e março de 1979. O resumo desta pesquisa está num livro que reúne dados sobre a repressão e a tortura que se abateram sobre o Brasil na Ditadura Militar. Para saber mais cf. ARQUIDIOCESE DE SÃO PAULO. Brasil: Nunca Mais. Petrópolis: Vozes, 1985.
} 
- não poderia prosperar sem a ajuda dos intelectuais revolucionários. Isso significa que um operário, individualmente, não poderia acessar por contra própria a teoria socialista: isso só seria possível na condição de revolucionários profisssionais, isto é, como intelectuais. Assim, os militantes seriam todos intelectuais. O operário, para se "candidatar" à condição de intelectual, deveria deixar sua condição original para, nessa metamorfose, perder as determinações de sua origem social (REIS FILHO, 1990, p. 144). O peso que o papel dos intelectuais tinha na dinâmica do PCB, mesmo que tomada em sua acepção mais formal, era grande. Como já vimos, não era coincidência que os órgãos de imprensa fossem dirigidos por figuras de proa no partido. Dirigir um jornal - tal como fizeram Lênin ou Marx - era coisa para poucos. Aqueles que comandavam a imprensa partidária tinham peso ou influência nas instâncias decisórias do partido. Em tempos de legalidade, essa influência, evidentemente, estendia-se até o parlamento e ajudava a moldar o perfil e o funcionamento da bancada comunista em todas as instâncias de representação - incluindo a Assembleia Constituinte.

Como vimos, o modelo oferecido por Daniel Reis Filho para análise das organizações comunistas dos anos 1960/70 pode ser utilizado para interpretar outras "organizações de estado-maior" inspiradas nas formas leninistas de organização e inscritas na tradição do bolchevismo da III Internacional. Consideramos, como sugere Marcelo Ridenti, que o modelo analítico proposto por Reis Filho é inclusive mais bem aplicável às organizações "rigidamente estruturadas nos moldes marxistas-leninistas", como o PCB dos anos 1940, do que para as esquerdas armadas do período militar (RIDENTI, 2010, p. 255). Resta verificar em que medida os mecanismos de coesão baseados nos mitos fundadores, na dinâmica excludente/antidemocrática, na "estratégia da tensão máxima" e no papel das elites sociais e intelectuais agiam sobre o PCB após 1945 e como influenciaram o trabalho de sua bancada na Constituinte de 1945.

\subsection{O PCB como organização de estado-maior}

Em maior ou menor grau, o PCB sempre buscou refletir a concepção bolchevique de organização partidária. Embora com notáveis lampejos de independência e criatividade, fazia parte do "ser comunista" referenciar-se na até então única revolução socialista vitoriosa. Já em 1926, na Revista Proletária, os comunistas brasileiros defendiam que: 
proletariado a noção fundamental de seu destino histórico e a compreensão sistematizada de seus profundos, de seus verdadeiros interesses (FERREIRA, 2002, p. 39)

A noção de que o proletariado detém ontologicamente o papel histórico de derrotar a exploração capitalista sobre os que vivem do trabalho, e de que este papel seria "revelado" pelo partido de vanguarda para promover a inevitável revolução socialista, já estava presente nos primeiros anos do PCB. Saindo do processo de reorganização, em 1943, o partido encontrava-se plenamente "bolchevizado". Isso significa que ele incorporara plenamente os pressupostos políticos, discursivos e organizativos do leninismo difundido pelo PC soviético o leninismo de Stálin. Esta constatação é autoevidente nos documentos oficiais do Comitê Central, nos discursos de seus deputados ao longo da Assembleia Constituinte, em toda a propaganda partidária e nos jornais comunistas. Além de plenamente alinhado à política das frentes populares antifascistas, formulada pela Internacional Comunista no final dos anos 1930, o PCB também adotara uma determinada forma de ser traduzida nas medidas organizativas e na visão que tinha de si e das classes trabalhadoras.

Logo após sua anistia, em maio de 1945, Prestes profere famoso discurso no estádio de São Januário, no Rio de Janeiro, em que apresenta as linhas gerais da "união nacional". Além disso, menciona o papel central do proletariado ao qual caberia

um papel dirigente e fundamental nesse grande avanço de unificação nacional, porque só a classe operária organizada sindicalmente pode realmente mobilizar as grandes massas populares e fazer com que a política nacional se desenvolva mais rapidamente no sentido da democracia e da liberdade (CARONE, 1982, p. 37).

Com isso, mesmo circunscrevendo o papel do proletariado à mobilização das massas em favor da "democracia e da liberdade" - e não do socialismo, já que a etapa a ser cumprida era democrático-burguesa - o PCB continua acreditando na missão revolucionária do proletariado que, como vimos, é um dos "mitos fundadores" que caracterizam as organizações de estado-maior. Ao mesmo tempo, a "imprescindibilidade do partido de vanguarda" está presente em diversos documentos. Mesmo em 1949, já depois do manifesto de janeiro do ano anterior, em que o PCB promove sua "apreciação autocrítica" defendendo uma guinada tática contra o governo Dutra, fica claro como o partido se vê diante do movimento operário. Mencionando Stálin, um documento afirma que “o Partido não apenas deve marchar para adiante, mas também arrastar consigo as grandes massas. Marchar para diante sem arrastar as grandes massas significa, de fato, ficar-se para trás do movimento, ficar-se à retaguarda do movimento" (Ibid, p. 103) 
No informe apresentado ao Comitê Central do partido em 1945 sobre a organização dos Comitês Populares Democráticos, espaços de mobilização contra a guerra e de recrutamento ao $\mathrm{PCB}$, fica clara a influência da estrutura leninista de organização. Após organizar uma "Comissão Provisória de Organização", diz o documento, esse organismo deve distribuir tarefas entre seus membros, visando "organizar um plano de reivindicações locais realizáveis", "coletar dinheiro" e "realizar toda a propaganda ao seu alcance - pela imprensa, volante, painéis, faixas, inscrições murais, etc." (Ibid., p. 58). Era o "massacre das tarefas" levado às instâncias de base do partido.

Na III Conferência Nacional do PCB, realizada em julho de 1946, as resoluções aprovadas reafirmam integralmente, em termos políticos e organizativos, a concepção leninista que o PCB tinha de si e da luta de classes no Brasil. Primeiro, acentua como tarefa urgente "elevar o nível político e ideológico de todo o Partido", uma vez que o próprio crescimento do PCB estaria "cada vez mais dependente da formação e educação de novos quadros, cujo atraso precisa ser vencido com energia, decisão e audácia” (Ibid., p. 70). Aqui notamos o chamado "leque das virtudes" operando para reforçar uma visão psicologizante da organização - que é tratada como sujeito de valores morais próprios - e seus efeitos sobre o conjunto dos militantes. Mais à frente o documento afirma que, diante das condições políticas do país, o crescimento do partido exige cada vez mais "homens firmes, comunistas conscientes, capazes de se orientar sozinhos, de isolados aplicarem a linha do partido, em condições, enfim, de sentir e compreender ou resistir a qualquer viragem”. Para cumprir esta tarefa, a III Conferência Nacional cria uma secretaria específica de educação e propaganda, com a tarefa de "ajudar decisivamente o trabalho de organização do Partido através da educação ideológica e política de seus quadros" (Ibid., p. 71). Com isso, reforça-se a celebração ao papel dos intelectuais comunistas, aqueles capazes de, através do estudo dedicado, compreender e transmitir a teoria revolucionária.

Assinalando que a luta pela paz, pela democracia e pelo progresso exigia um "forte e poderoso Partido Comunista", a III Conferência aponta a necessidade de "dar a máxima atenção ao trabalho de fortalecimento das direções" com vistas a promover "os militantes que demonstrem possibilidades de se transformarem rapidamente nos dirigentes que necessitamos". Para tanto, "a política de concentração deve constituir um dos objetivos fundamentais de todos os organismos do Partido" (Idem). Ou seja, o crescimento do partido reclamava não uma maior integração das bases com vistas à democratização das decisões, mas uma maior concentração das decisões nas cúpulas partidárias com objetivo de evitar “desvios” em relação à linha oficial aprovada pelas instâncias superiores. A máxima 
observância à "linha oficial" é parte das exigências da militância comunista, contra a qual operam o complexo da dívida e a síndrome da traição.

A celebração da autoridade - encarnada, sobretudo, no culto a Stálin, mas também a Prestes - também é facilmente constatada em vasta bibliografia e na imprensa comunista da época. A partir da eleição de 1945, o partido comunista se convertia cada vez mais no "partido de Prestes e do povo". Mesmo que tenha tido uma militância partidária extremamente limitada antes da reorganização do partido, Prestes fora profundamente associado ao PCB após a democratização e mesmo antes dela (vale lembrar que Prestes foi eleito SecretárioGeral do partido durante a Conferência da Mantiqueira mesmo estando preso). Evidentemente, a mística de Prestes antecedia a seu ingresso no partido, graças à extraordinária marcha que liderara nos 1920. Mas o "Cavaleiro da Esperança", como ficou conhecido depois da obra de Jorge Amado, foi o típico exemplo do culto à personalidade do período em que vigorou a hegemonia stalinista sobre os partidos comunistas de todo o mundo. Enquanto para o secretário-geral do PC soviético eram reservados os títulos de "guia genial dos povos", "maior defensor da paz" e "mestre e guia amado", para Prestes utilizavam-se os epítetos de "líder do proletariado e do povo brasileiro", "campeão continental da luta contra o imperialismo" e "grande esperança do povo" (FERREIRA, 2002, p. 251).

A ambivalência das orientações políticas, outra característica atribuída às organizações de estado-maior, ficaria por conta da própria política de "união nacional" defendida pelo partido. Ora pedindo ordem e tranquilidade aos inquietos trabalhadores urbanos, ora conclamando à mobilização contra os resquícios fascistas; ora empenhando-se na luta em favor das medidas democráticas do governo Dutra, ora denunciando as medidas autoritárias do mesmo, a política de "união nacional” foi a expressão máxima da ambivalência política do PCB nos anos 1940.

O massacre das tarefas é percebido na já mencionada passagem de Gregório Bezerra, quando afirma que suas atividades na Assembleia Constituinte foram modestas porque "havia enorme acúmulo de tarefas partidárias e de massas" que recaíram sobre ele, mesmo após sua eleição (BEZERRA, 1979, p. 358). A infinidade de reuniões, a opção por realizar prestações de contas dos mandatos em praça pública, o trabalho da imprensa partidária, a formação política, as células de base, as iniciativas nas frentes de massas (sindical, popular, juventude, etc.), faziam do militante comunista uma fonte inesgotável de energia a serviço do partido. Como lembra Leôncio Basbaum sobre o período, "minha vida mudou inteiramente de rumo, acabaram-se os namoricos e bailaricos e praticamente me isolei dos poucos colegas para me consagrar por inteiro às minhas tarefas" (FERREIRA, 2002, p. 89). 
Portanto, não é difícil demonstrar o quanto o PCB dos anos 1940, com seu processo de bolchevização concluído, era uma típica organização de estado-maior, como descreve Daniel Reis Filho: uma liderança excludente e altamente verticalizada, sustentada em mitos fundadores comuns a qualquer organização comunista, mas baseada em instrumentos que visam manter máxima tensão (massacre das tarefas, celebração da autoridade, ambivalência das orientações políticas etc.) e a coesão do corpo partidário. Ao mesmo tempo, consideramos ter demonstrado o papel das elites sociais e intelectuais na reprodução dos padrões organizativos importados do leninismo de Stálin, no qual os homens das letras, o estudo, o conhecimento e a imprensa revolucionária cumprem um papel central.

No entanto, é forçoso admitir que a natureza centralizadora do leninismo sofreu inegáveis abalos com a política de abertura do PCB que buscou transformá-lo num "partido de massas". Diferente do partido que existiu até a reorganização, clandestino, de quadros, restrito à defesa dos interesses do proletariado, o tipo de partido perseguido pelos comunistas a partir de 1945 era um amplo partido de massas, que permitisse a filiação de todos aqueles que aceitassem as determinações de seu estatuto ${ }^{64}$ e vinculado aos interesses de "todo o povo" e não de uma classe específica (PANDOLFI, 1995, p. 145). Dulce Pandolfi lembra que, durante a legalidade, foram contrariadas todas as normas de filiação oficialmente estabelecidas pelo partido em favor de critérios mais "frouxos" de recrutamento. Ao contrário das rígidas regras de filiação, as fichas para ingresso no partido chegaram a ser distribuídas em logradouros públicos, sendo seu preenchimento suficiente para ingressar no PCB (Ibid., p. 146).

Esse crescimento, embora louvado como parte do processo de transformação do partido numa organização de massas, era também objeto de preocupação. Buscava-se manter a uniformidade e a homogeneidade, evitando influências consideradas nefastas ao PCB:

Sem dúvida, existem distintos graus de inserção e pertencimento a uma organização
comunista. A identidade é um processo que depende da socialização. Na realidade, o
"ser comunista" é algo mais forte do que o "ser filiado" a uma organização
comunista. Durante o período de legalidade, como o objetivo era transformar o
antigo partido de quadros em uma organização de massas, os dispositivos rígidos
para ingresso no partido foram relaxados. Contudo, acreditava-se que aqueles novos
filiados iriam sofrer um processo de "conversão". Através, sobretudo, dos estudos do
marxismo-leninismo, eles se transformariam e "verdadeiros comunistas"
(PANDOLFI, 1995, p. 149).

${ }^{64}$ Sobre os estatutos, já vimos que, para atender aos requisitos da Justiça Eleitoral, o PCB não faz referências ao marxismo, à luta de classes, ao leninismo ou à ditadura do proletariado. No entanto, Pandolfi lembra que, na verdade, naquele período o partido possuía dois estatutos: um legal, registrado junto às autoridades eleitorais, e um clandestino, para atender à proposta partidária leninista (PANDOLFI, 1995, p. 145). 
No entanto, se as análises de Pandolfi parecem corretas quanto às transformações vividas pelo PCB em sua estrutura organizativa, é presumível que essas transformações tenham se mantido restritas aos níveis mais baixos da organização. Com isso, conviviam dentro do mesmo partido uma organização de massas para a imensa maioria dos filiados e um partido de quadros de tipo leninista para os níveis superiores de direção.

Em todos os documentos disponíveis, as referências à hierarquia partidária e suas instâncias mostram-se fiéis às concepções leninistas e as preocupações quanto ao risco de desvios se circunscreve às instâncias de base. Ademais, como demonstramos, a escolha para os membros dos organismos superiores segue rigorosamente os critérios característicos das organizações de estado-maior, com grande presença de intelectuais dedicados integralmente ao trabalho partidário profissional, o que se reproduz também na bancada comunista que atuou em nome do PCB na Assembleia Constituinte e na divisão de trabalho entre deputados "letrados" e "operários".

\subsection{Entre a intenção e o gesto}

Leôncio Martins Rodrigues, analisando a relação entre as instâncias de direção e a origem social de seus dirigentes, oferece-nos uma alternativa interpretativa para compreender os limites na democracia partidária do PCB. Segundo ele, a crescente influência das classes médias e dos militares a partir dos anos 1930 nas esferas de direção do partido teria colaborado para os sucessivos erros de interpretação da realidade brasileira, donde se destacaria a "quartelada" de 1935 (RODRIGUES, 1997, p. 383). Ele ressalta, todavia, que:

\footnotetext{
Não se pretende afirmar que os membros das classes trabalhadoras fossem capazes de uma apreciação mais correta da situação política nacional, mas sim que o tipo de política, a tática e a orientação ideológica do PCB refletiram o declínio da participação operária e popular em benefício das classes médias e altas (Idem).
}

No entanto, todo o seu argumento visa demonstrar que as dificuldades do PCB em vincular-se às massas e interpretar corretamente seus desejos têm origem na composição social das instâncias dirigentes do partido. Embora nos pareça bastante reducionista, há pelo menos dois elementos com os quais Rodrigues aporta importante contribuição à análise que buscamos desenvolver neste trabalho. O primeiro é a confirmação, a partir de uma abundante documentação, da enorme desigualdade na ocupação dos espaços de direção do PCB em diferentes épocas, com forte predomínio de elementos oriundos das classes médias e altas. $\mathrm{O}$ 
segundo, é a relação entre a ocupação dos espaços de direção e as condições materiais que permitiam ou impediam a determinado indivíduo sua ascensão à condição de "revolucionário profissional" tal como exigido pela estrutura leninista do partido.

Sobre o primeiro elemento, Rodrigues demonstra que, de um partido fundado por operários de formação anarquista, o PCB foi gradualmente transformando-se numa agremiação predominantemente dirigida por indivíduos cujas origens remetem aos setores médios e superiores do extrato social brasileiro. Seu estudo destaca que

os dirigentes do PCB provieram fundamentalmente dos intelectuais (especialmente jornalistas e professores), profissionais liberais (médicos e advogados) e, em meados da década de trinta, do Exército (capitães e tenentes), quase todos eles de famílias tradicionais brasileiras, do Nordeste e do Estado do Rio, especialmente (Ibid., p. $385)$.

Quando o PCB volta à legalidade, em 1945, como já demonstramos, são precisamente indivíduos oriundos destes setores que ocuparão as instâncias de direção e os órgãos da imprensa comunista. O segundo elemento que atesta um processo de "seleção natural" entre as classes sociais é a dinâmica imposta pelo trabalho político nos moldes leninistas adotados pelo PCB. Segundo ele, os intelectuais de renome, por exemplo, mantinham-se normalmente afastados do centro decisório do partido devido às exigências do trabalho político profissional. Segundo ele, a ascensão na hierarquia de um partido como o PC exigia, dentre outras qualidades, dedicação integral ao Partido, disciplina partidária e respeito à rigidez ideológica imposta pela ortodoxia da época (Ibid., p. 412). Estes elementos, seguramente, eram menos impeditivos a lideranças populares que, ademais, poderiam ter nas instâncias superiores do partido um meio de diferenciação social e status. Ainda assim, os dados fornecidos por Rodrigues atestam justamente o contrário, mostrando que, mesmo diante de contradições menores com as exigências partidárias de tempo e dedicação, ainda assim, os militantes oriundos das classes populares eram, não raro, destacados para tarefas que não incluíam a presença nas instâncias decisórias mais importantes.

A explicação de Rodrigues, entretanto, atribui um peso excessivo às variáveis associadas à origem social dos dirigentes pecebistas como meio para explicar as posições políticas do partido. A pretensa associação entre os erros políticos e a incapacidade de interpretar corretamente os anseios do proletariado por conta da classe de origem da maioria dos dirigentes do PCB nos parece insuficiente como alternativa interpretativa. Assim fosse, partidos cuja presença de operários nas instâncias de direção fosse significativa estariam melhor preparados para representar esses interesses, coisa que a história política recente do 
Brasil mostra não ser condizente com a realidade.

Diferente de Rodrigues, pensamos que não é propriamente a origem social que provoca a diferenciação na ocupação de espaços nas instâncias de direção no partido e na bancada do PCB. A diferenciação existe a priori e é parte da dinâmica das sociedades de classe em que estão inseridos todos os partidos comunistas fora do poder. Lutar contra ela aderindo às muitas formas de glorificação do operariado já se mostrou incapaz de reverter certa tendência à centralização do poder decisório entre indivíduos oriundos das camadas médias e superiores ${ }^{65}$.

Sustentamos, ao contrário, que essa divisão, existente como elemento exterior ao PCB, foi potencializada nos anos 1940 pela estrutura de funcionamento adotada pelo PCB enquanto organização de estado-maior de tipo leninista, onde o lugar do trabalho profissional, o domínio da teoria revolucionária e a capacidade de interpretá-la, bem como a dedicação integral à burocracia partidária, são elementos hipervalorizados política e culturalmente.

Assim, a ocupação desigual dos espaços nas instâncias de direção, na imprensa e a “divisão social" do trabalho dos parlamentares comunistas na Assembleia Constituinte entre letrados e operários - estes últimos relegados a um segundo plano em relação àqueles - é resultado direto da estrutura leninista assimilada pelo PCB desde sua reorganização, que privilegia a ascensão de indivíduos com mais condições de acesso à doutrina marxistaleninista e com maior disposição para o trabalho político profissional. A origem deste padrão organizativo, como vimos, está na divisão entre mencheviques e bolcheviques e encontra amparo até mesmo no nascimento do movimento socialdemocrata do século XIX, dirigido por vários "homens das letras". Esta constatação poderia levar-nos a naturalizar o processo de centralização política dos partidos comunistas como inerente a todos os partidos, sugerido por Michels. Uma vez que a natureza das organizações de estado-maior é ontologicamente marcada pelas características descritas neste capítulo, seria possível ter partidos comunistas imunes à "lei de ferro" da oligarquização?

Não é objeto deste trabalho desenvolver uma discussão de fundo entre meios e fins políticos, especialmente na análise de um período tão curto e de tantas transformações como aquele que se inscreve entre a reorganização do PCB, sua legalização e posterior cassação. De qualquer forma, consideramos que nenhuma análise válida sobre a natureza organizativa e política dos comunistas brasileiros no referido período pode se assentar unicamente em

\footnotetext{
${ }^{65} \mathrm{Um}$ dos exemplos foi a tentativa de infiltrar elementos da classe média em fábricas com o duplo objetivo de "proletarizar" a organização e recrutar operários. O máximo exemplo desta experiência, chamada comumente de "obreirismo", foi desenvolvido por algumas organizações clandestinas que lutavam contra a Ditadura Militar.
} 
fatores exógenos - caráter restritivo da democracia liberal de 1945, anticomunismo, imaturidade política da classe operária, dependência teórica e política em relação à União Soviética, dentre outros - bem como unicamente em fatores endógenos - autoritarismo imanente dos partidos comunistas, origem social de seus membros, assimilação incorreta dos "verdadeiros" preceitos do leninismo etc. Uma análise assentada nas referências explicitadas no primeiro capítulo deste trabalho, e na análise concreta do percurso histórico descrito no capítulo seguinte, deve considerar, nas palavras de Gildo Marçal Brandão, não o "dever ser" da revolução que o PCB não quis ou não pode fazer, mas o exame da gênese retardatária e a função social da "via brasileira ao socialismo" num contexto de construção de uma nova ordem burguesa no Brasil dos anos 1940. Em outras palavras: compreender como um sujeito político é "filho do seu tempo" (BRANDÃO, 1997, p. 31).

Recém-saídos da clandestinidade a que foram condenados não apenas por seus erros táticos, mas também pela indisposição das elites brasileiras em conviver com um corpo estranho como o PCB, os comunistas se adaptaram rapidamente à democracia liberal surgida como resultado na luta entre as diferentes frações da burguesia brasileira. Obtiveram um excelente resultado eleitoral apenas semanas depois de conquistarem seu registro legal e tiveram um importante papel na promulgação de uma Constituição que, se bem que limitada, significou um avanço em relação ao Estado Novo. Nesse percurso, o PCB defendeu os direitos sociais de todos os explorados, o Estado laico, a independência de poderes, o fim dos mecanismos repressivos, os direitos das minorias indígenas e das maiorias negras, a extinção do Senado, o controle estatal sobre a economia, a defesa dos recursos naturais e uma relação de cooperação com os demais países, baseada na cultura da paz e da coexistência pacífica. Diante desse histórico é difícil conceber, como sugerem alguns, que o PCB foi incapaz de se adaptar à democracia, seja por sua natureza internamente antidemocrática e excludente, seja pela proclamação de seus princípios revolucionários - ademais, totalmente abandonados no período mencionado.

A relação do PCB com a nova ordem, independentemente de juízos sobre a correção da tática de "união nacional" 66 , produziu transformações tanto no partido quanto na realidade sócio-política que nasceu após os trabalhos da Assembleia Constituinte. Ao contrário do que imaginam alguns, foi precisamente quando buscou tornar-se um partido de massas que o PCB se vinculou mais fortemente à dinâmica real da luta de classes, relativizando o peso dos elementos de coesão - a estrutura leninista de organização - para a ampla maioria de seus

\footnotetext{
${ }^{66}$ Já deixamos suficientemente explícito no início deste capítulo nossa avaliação crítica dos efeitos da tática de União Nacional, sendo desnecessário retomar um balanço sobre o tema.
} 
membros. Essas transformações não alcançaram os níveis mais altos da hierarquia partidária ou da bancada comunista na Constituinte, como vimos. Mas elas não estavam imunes a seus efeitos. Nunca saberemos que resultados teria a exposição prolongada de um partido de massas com as características do PCB a uma democracia liberal - para o bem e para o mal.

A proposta de "democracia progressiva", uma espécie de estratégia de transição pacífica e democrática do capitalismo para o socialismo, ganhava cada vez mais centralidade nas posições do PCB (PANDOLFI, 1995, p. 165). Essa perspectiva estava em franca expansão na Europa, após ser formulada por Palmiro Togliatti e assumida pelo partido comunista italiano em 1945. Para Dulce Pandolfi, a assimilação deste conceito por parte do PCB representava uma clara "ruptura com a concepção bolchevique de revolução". Por que não supor que, como aconteceu com outros partidos comunistas, essa adaptação poderia produzir profundas transformações em sua dinâmica interna?

Além disso, como destaca Brandão, o PCB conquistou força relativa junto às classes trabalhadoras e, qualquer que fosse a sua própria orientação ou sua estrutura interna, tenderia, por força da ausência de outros partidos operários de massas, a manter boa representatividade dentro do jogo eleitoral e questionar as bases do populismo plebiscitário emergente (BRANDÃO, 1997b, p. 27). Explicar a opção pela forma de organização de estado-maior apenas pela "tradição" em que se inscrevia o PCB é uma opção extremamente unilateral. Além dos "mandamentos" do leninismo, essa forma respondia também a condições históricas: os mais de 20 anos de ilegalidade a que esteve submetido o PCB foram produzidos por sua dinâmica interna, pelo conteúdo dos estratos sociais que o compunham ou por uma opção consciente pela marginalidade política. $\mathrm{O}$ veto à participação política formal imposto pelas elites aprofundou a dependência política de modelos externos e manteve vigente, como que por inércia, determinadas práticas internas ${ }^{67}$. Isso, obviamente, não deve ser um atenuante em relação a suas debilidades, limitações, muito menos às suas responsabilidades pela adoção de posições políticas equivocadas que subestimavam adversários ou hipervalorizavam o prestígio do PCB como "partido da classe". Como, felizmente, não estamos num tribunal histórico, estas ressalvas são supérfluas.

A opção do PCB foi buscar construir um elo entre a ação da classe e a participação institucional, o que não lhe foi permitido pelas elites nacionais de forma duradoura (Ibid., p. 29). Apesar disso, a curta experiência do partido no contexto da legalidade democrática

\footnotetext{
${ }^{67}$ Basta lermos os relatos sobre o aparato de segurança que o PCB manteve após sua legalização, descritos por Daniel Aarão Reis Filho na recém-publicada biografia de Luís Carlos Prestes e a "nostalgia" da clandestinidade.
} 
limitada de 1946 e sua participação na Assembleia Constituinte daquele ano nos permite perceber os efeitos da experiência democrática sobre o partido, independente da influência objetiva de modelos exteriores ou dos duros anos de ilegalidade que levaram o partido a adotar um modelo organizativo excludente e antidemocrático. Independente do grau de consciência que os comunistas tinham em relação a suas possibilidades históricas, está claro que sua permanência enquanto ator do jogo político legal transformaria não apenas a dinâmica da luta de classes no Brasil, mas, fundamentalmente, sua própria estrutura enquanto partido, aproximando meios e fins, ou ainda, intenção e gesto. 


\section{CONSIDERAÇÕES FINAIS}

Como se pode perceber, optamos por realizar um percurso que teve início com os problemas envolvendo os estudos da história política e que passou pela verificação de algumas hipóteses na experiência concreta do Partido Comunista Brasileiro para, em seguida, propor uma síntese interpretativa que apontasse algumas conclusões sobre a história dos comunistas na complexa experiência da democratização vivida pelo Brasil a partir de 1945.

O mundo que surgiu dos escombros da Segunda Guerra Mundial era uma mescla entre o velho e o novo. De um lado, fortaleceu as tendências que levavam gradualmente os Estados Unidos à condição de superpotência do mundo ocidental, de outro, soterrou o nazifascismo que ameaçara o mundo por vinte anos - apesar dos "resquícios" presentes em países como Espanha e Portugal. No campo das esquerdas, a Segunda Guerra Mundial fortaleceu o poderio da União Soviética como líder absoluta entre as nações socialistas, mas também fez surgir as chamadas "democracias operárias", como na Iugoslávia, e fortaleceu outras vias possíveis ao socialismo na China e na Itália, por exemplo. No Brasil, o fim da Segunda Guerra Mundial ajudou a colocar fim a uma Ditadura que durara oito anos e a viabilizar uma ponte para a democratização. Mas esse processo redundou na eleição de um candidato à presidente apoiado pelo ditador e seu partido e na conformação de uma democracia limitada e excludente. Entre os comunistas brasileiros, o fim da guerra simbolizou o fim da clandestinidade, a abertura para a formação de um partido de massas e o contato com um novo ordenamento institucional, porém, sem alterar significativamente a natureza de "organização de estadomaior" do PCB e seus pressupostos políticos e filosóficos fundamentais. Como se nota, o imediato pós-guerra é um tempo de rupturas e continuidades, de convivência entre o velho e o novo, de transição. É difícil, pois, chegar a conclusões peremptórias sobre a atuação da bancada comunista na Assembleia Constituinte. A natureza contraditória daquele espaço, as transformações pelas quais passavam o país e o mundo e a metamorfose que o próprio PCB vivia, turvam nossa análise e alimentam ainda hoje incontáveis controvérsias historiográficas sobre esses temas.

Em primeiro lugar, podemos concluir que a transição pelo alto, conduzida pelas forças políticas comprometidas com a construção de uma nova ordem político-institucional que mantivesse intocados os interesses das elites nacionais, foi parcialmente bem-sucedida. Como destaca Giovanetti Netto, "as linhas de continuidade e permanência pairaram muito acima dos apelos democratizantes, revelando a força e eficácia na transmissão para o novo período que 
se iniciava, elementos característicos do Estado Novo" (NETTO, 1982, p. 1984). As eleições de 1945 não colocaram em risco o establishment, já devidamente preservado pelo golpe de outubro daquele ano, e os partidos surgidos da democratização, com a exceção do PCB, serviram como instrumentos de mediação entre o Estado e determinadas frações da sociedade. Como resultado, este processo de transformações deu origem a uma democracia representativa limitada.

No caso da Assembleia Constituinte, constatamos facilmente os efeitos dessas limitações sobre o processo legislativo. Propostas que buscavam assegurar a ampliação de direitos civis, políticos e sociais, foram constantemente barradas pelos maiores partidos da Assembleia Constituinte, quando não sumariamente ignoradas. A subalternidade em relação ao governo Dutra e aos resquícios do Estado Novo, seja na aceitação da utilização da carta constitucional de 1937 como base para a nova Constituição, seja na dificuldade de legislar enquanto o governo editava centenas de decretos-lei, também atesta as fragilidades da Constituinte e sua resistência às reformas políticas, sociais e econômicas reclamadas por diversos setores da sociedade. O resultado é, portanto, uma carta constitucional que assegurou a ampliação de direitos políticos básicos, mas pouco contribuiu para viabilizar um processo de democratização pleno da vida política do país.

Neste contexto, o PCB apostou todas as fichas numa democratização cujo sucesso dependia de múltiplos fatores. Nos meses anteriores à queda de Vargas, o movimento popular vinha retomando a iniciativa política: no fim de 1943, os estudantes saíram às ruas pedindo o fim do Estado Novo, após o bombardeio aos navios brasileiros pela marinha alemã, um forte movimento exigiu do governo Vargas a entrada no Brasil na guerra que se desenrolava na Europa, enquanto os trabalhadores organizavam greves e protestos em todo o país. Às vésperas do retorno à democracia, a anistia permitia a libertação de muitos dirigentes comunistas e a legalização de todos os partidos. Paralelamente, Vargas organizava o Partido Trabalhista Brasileiro (PTB) com o objetivo de frear a influência comunista entre os trabalhadores e criar uma referência reformista a partir da legislação herdada do Estado Novo (GOMES, 2005, p. 95). Assim, o processo de democratização encontrou um cenário politicamente convulsionado e pouco propício à tática da "união nacional" e às promessas de paz duradoura que ela trazia consigo.

Mesmo assim, o PCB levou essa política às últimas consequências. Pouco antes da posse de Dutra, o Comitê Nacional do partido reafirmou a tática de "união nacional" e aprovou o "apoio franco e decidido" aos atos democráticos do novo presidente e a "luta intransigente, se bem que pacífica, ordeira e dentro dos recursos legais" a eventuais 
retrocessos reacionários. Acreditando nas possibilidades que a democratização abria, a plataforma do PCB à Constituinte teve como centro as tarefas de constituição de uma típica democracia liberal. Após oito anos de Ditadura, não era uma plataforma menos importante. Mas até onde poderia o PCB subordinar outras conquistas políticas e econômicas dos trabalhadores a essa tarefa?

Com o início da Constituinte, o partido foi colocado numa posição extremamente delicada. De um lado, preservou Dutra de ataques diretos. De outro, denunciou a orientação conservadora assumida, desde o início, pelo governo e pela Assembleia; enquanto isso, defendia que os trabalhadores deveriam se dedicar à construção da Unidade Nacional, da paz e da ordem social, mesmo que, para isso, precisassem "apertar o cinto". A busca da paz a qualquer custo levou o PCB a uma clara política de colaboração de classes. Prova disso foi a posição do partido diante das várias greves que eclodiram no período. Num primeiro momento, os comunistas chegaram a desestimular seguidamente as manifestações e as greves. Aliás, não era raro imputá-las a "provocadores" que queriam desestabilizar a nascente democracia.

$\mathrm{Na}$ da Assembleia Constituinte, o PCB agia isolado na maioria das vezes. Um clima de hostilidade permeava a relação dos demais parlamentares - especialmente os da UDN e do PSD - com os deputados comunistas. O deputado Octávio Mangabeira (UDN/BA), no episódio envolvendo as polêmicas declarações de Prestes sobre uma hipotética guerra entre Brasil e URSS, declarou que seu partido estava pronto a cooperar com o governo Dutra na repressão às atividades comunistas no Brasil. A imprensa, por sua vez, buscava desgastar a imagem do PCB, abordando sua atuação na Constituinte como algo incompatível com a democracia. O jornal $O$ Estado de São Paulo afirmara que “Os comunistas, já no primeiro dia de verificação de poderes, se salientaram como elementos perturbadores da marcha dos trabalhos" (NETTO, 1985, p. 93). Como se percebe, o PCB foi visto pela grande imprensa e pelos demais partidos como um corpo estranho, um convidado indesejável na Assembleia Constituinte. Este sentimento só aumentava a cada episódio em que o partido entrava em sintonia com as expectativas populares.

No interior da bancada, como vimos, vigorou uma dinâmica que privilegiou deputados oriundos das classes médias ou com acesso a um razoável nível de educação formal. A divisão entre "letrados" e "operários", facilmente observável na quantidade de emendas, discursos, apartes e demais medidas legislativas propostas por cada uma dessas "bancadas", é consoante com as abordagens que destacam a profunda desigualdade na ocupação dos espaços de 
direção do PCB, a partir dos anos 1930, e a natureza excludente e antidemocrática do partido em relação à ascensão das classes populares às suas instâncias de direção.

Mas, diferentemente dessas abordagens, não consideramos que a formação de elites sociais e intelectuais no interior do partido seja a chave para a explicação de fenômenos externos, isto é, não consideramos que atestar a natureza excludente das organizações de estado-maior seja suficiente para explicar opções políticas, táticas ou leituras equivocadas da realidade ao longo da história do PCB. Como pensamos ter demonstrado, a estrutura leninista dos partidos "bolchevizados" pela política de homogeneização da Internacional Comunista apenas amplificou uma divisão inerente às sociedades de classes como no Brasil, fundadas na profunda desigualdade material e simbólica entre aqueles que tiveram ou não acesso aos meios formais de educação. A assimilação dos pressupostos descritos por Daniel Aarão Reis Filho como inerentes às organizações de estado-maior apenas aprofundou a divisão e interditou transformações nas formas de conceber a organização.

Como vimos, essas características ganham relevância à medida que o partido se matem à margem dos processos sociais e políticos mais relevantes. Ao entrar em contato com a dinâmica da luta de classes, com todas as suas contradições e exigências, o modelo organizativo perdeu força - ao menos na base da "pirâmide" do PCB -, demonstrando que a estrutura hierárquica rígida herdada do processo de "bolchevização" não era impermeável às tensões da luta política. Infelizmente, a efêmera vida legal dos comunistas no pós-guerra não nos permitiu observar mudanças nos níveis mais altos das instâncias partidárias, que seguiram reproduzindo o modelo leninista quase sem mediações. Ademais, como lembra Marcelo Ridenti em relação às organizações de estado-maior dos anos 1960/1970, as normas de funcionamento interno das organizações de esquerda não eram tomadas pelos militantes como algo imposto contra sua vontade, mas consideradas legítimas e necessárias. No entanto, discordamos dele quando afirma que "as críticas a essas normas só cresceriam no seu interior na medida em que aumentasse seu isolamento social" (RIDENTI, 2010, p. 260). Ao contrário: é sua ampliação e o fim de seu isolamento social que colocam em xeque um padrão organizativo pensado para pequenas organizações conspiratórias do começo do século. Foi assim que o "bolchevismo" foi abandonado por vários partidos de massas ao longo do século $\mathrm{XX}$, e não o contrário.

Entre as conclusões da participação dos comunistas na Assembleia Constituinte, Giovanetti Netto sugere que a rápida mudança da conjuntura nacional e internacional não foi devidamente percebida pelo PCB graças à lentidão de sua direção e a precária relação desta com suas bases (NETTO, p. 1982, p. 195). Não verificamos, no entanto, em que medida esses 
fatores possam ter contribuído com a cassação do PCB, uma vez que as iniciativas tomadas pelas elites políticas para inviabilizar a presença do partido no jogo político-eleitoral foram desde o princípio denunciadas pelos comunistas em todas as frentes, inclusive no parlamento. Embora a problemática da crítica (prefiro aos termos absolvição ou condenação) ao PCB seja complexa, não podemos deixar de mencionar que sua derrota está inscrita num contexto muito mais amplo de perseguição aos partidos comunistas, o que não exime, evidentemente, os comunistas brasileiros diante da notória superestimação das possibilidades que a democracia representativa oferecia num processo de transição conservadora. Tampouco se trata de forjar um debate com o PCB, confronto do qual sempre saímos vitoriosos, pois necessariamente prejudicada pela defasagem histórica e até pela ausência de interlocutor (ALMEIDA, 2003, p. 85). Apenas devemos, como sugerem alguns autores, compreender que os fatores endógenos burocratização, apego a modelos interpretativos rígidos, dependência teórica, os "erros de Prestes", a predominância de elementos "pequeno-burgueses" nas instâncias de direção jamais poderão explicar por si só os rumos do PCB. Para isso, é necessário colocar estes elementos em constante diálogo com os elementos exógenos, a saber, o nível de consciência dos trabalhadores assalariados urbanos, a natureza do sistema político, seus limites e fragilidades, a correlação de forças interpartidárias, as relações do país com outros sujeitos no plano internacional, o início da guerra fria; dentre outros. Em outras palavras, não é possível considerar que a derrota sofrida pelo PCB em 1947 possa ser atribuída apenas a ele próprio, como boa parte da historiografia tem feito.

Sobre a presença do PCB na Assembleia Constituinte, podemos afirmar com segurança que a intervenção dos comunistas buscou permanentemente o aprofundamento da democracia política e social e a consolidação/ampliação de direitos. Ao todo foram realizadas 180 sessões durante os trabalhos da Constituinte, sendo que a primeira sessão se realizou em

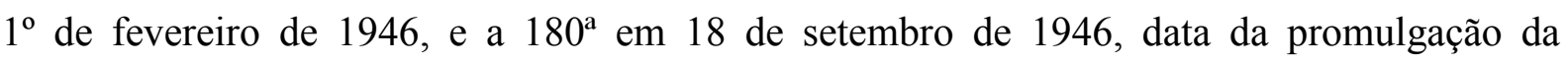
Constituição. Analisando as proposições e discursos dos parlamentares do PCB, percebemos que as iniciativas da bancada comunista tinham como objetivo a garantia das liberdades individuais e coletivas. O partido entendia que a construção de uma democracia estável era parte da estratégia de aliança com setores das classes dominantes para fazer avançar a luta pelo socialismo e superar a etapa "democrático-burguesa" da revolução brasileira. Por isso, a opção por defender transformações de maneira "ordeira e pacífica" e não afrontar diretamente o governo conservador do General Dutra. Ainda que movida por uma análise incorreta da realidade brasileira - característica das interpretações do marxismo para o Brasil nos anos de 1940, marcada pelo menosprezo à cultura política conservadora dos diversos setores sociais 
brasileiros (trabalhadores, pequena burguesia, setores médios etc.), pela subestimação das forças conservadoras e pela exagerada confiança na frágil democracia aberta com o fim do Estado Novo - não podemos desconsiderar o contexto no qual esta estratégia se desenvolveu.

Obviamente que, para as perspectivas de um partido efetivamente comprometido com a superação da ordem capitalista, mesmo numa estratégia de aliança de classes, a Constituinte foi bastante frustrante. Por ocasião do $1^{\circ}$ aniversário da promulgação da Constituição de 18 de setembro de 1946, Prestes reconheceu, em discurso proferido no Senado, que "se não fizemos uma Constituição progressista, promulgamos uma Constituição democrática" (BRAGA, 2003, p. 649). A afirmação revela uma indisfarçada frustração. É inegável, porém, que mesmo para esse tímido resultado, a contribuição da bancada comunista foi decisiva. 


\section{REFERÊNCIAS}

Fontes:

ABREU. A. de A. Dicionário Histórico Biográfico Brasileiro (1930-1983). Rio de Janeiro: Editora FGV, 1984.

ALBERTI, V. O século do moderno: modos de vida e consumo na República. In: GOMES, A. M. de C.; PANDOLFI, D.; ALBERTI, V. (coord.). A República no Brasil. Rio de Janeiro: Nova Fronteira, 2002.

ARQUIVO DE MEMÓRIA OPERÁRIO DO RIO DE JANEIRO (AMORJ). Partido Comunista Brasileiro: da insurreição armada à união nacional (1935-1947). Rio de Janeiro: AMORJ/UFRJ, 2009.

ARQUIVO PÚBLICO DO PARANÁ. Delegacia de Ordem Política e Social (DOPS). Curitiba. Carta circular $n^{\circ} 1$ do Secretariado Nacional a todos os Comitês Estaduais $e$ Territoriais do Partido Comunista do Brasil: "Mobilização de todo o Partido para a campanha eleitoral”, fls. 261-265, Pront. 1468d, Top. 174, Partido Comunista Brasileiro. 03 set. 1945.

BRAGA, S. S. Quem foi quem na Assembleia Nacional Constituinte de 1946. Um perfil socioeconômico da Constituinte de 1946. Brasília: Câmara dos Deputados, 1998.

. Luiz Carlos Prestes. O Constituinte, o Senador (1946-1948). Brasília: Senado Federal. Edições do Senado Federal, vol. 10., 2003.

BRASIL. Assembleia Constituinte. Anais da Assembleia Constituinte de 1946. Rio de Janeiro: Imprensa Nacional. 1946-1951. set. 1946 .

Diário da Assembleia Constituinte. Rio de Janeiro: Imprensa Nacional, 02 fev., 19

Lei $n^{\circ}$ 648/1949. Câmara dos Deputados. Disponível em:

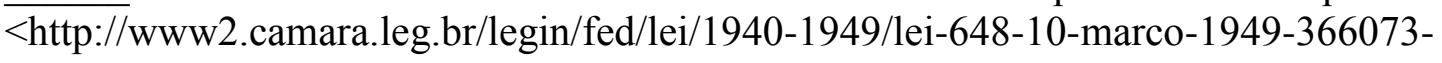
publicacaooriginal-1-pl.html>. Acesso em: 20, dez., 2015.

. Processo de Registro do Partido Comunista do Brasil. Tribunal Superior Eleitoral. Distrito Federal: 1945.

. Processo 411/412 - Cancelamento do Registro do Partido Comunista do Brasil. Distrito Federal: 1947.

. Dados estatísticos: eleições federal, estadual e municipal realizadas no Brasil a partir de 1945. Distrito Federal: 1950.

. Eleições de 15 de novembro de 1986. Candidatos e votos obtidos. Brasília: Centro de Documentação e Informação/Coordenação de Publicações, 1987.

CARONE, E. O PCB (1922-1943). São Paulo: Editora Difel, vol. I, 1982. 
O PCB (1943-1964). São Paulo: Editora Difel, vol. II, 1982.

FOLHA DA MANHÃ. O Momento político. São Paulo, p. 12., 02 fev. 1946.

FRANCO, A. A. de M. A Câmara dos Deputados - Síntese Histórica. Brasília: Câmara dos Deputados, 1978.

GIOVANNETTI NETTO, E. O PCB na Assembleia Constituinte de 1946. São Paulo: Editora Novos Rumos, 1986.

OUTHWaite, W.; BOTTOMORE, T. (org.). Dicionário do Pensamento Social do Século $X X$. Rio de Janeiro: Jorge Zahar, 1996.

SANTOS, W. Votos e partidos: almanaque de dados eleitorais; Brasil e outros países. Rio de Janeiro: Fundação Getúlio Vargas, 2002.

\section{Bibliografia:}

ALÉM, S. F. Os trabalhadores e a redemocratização: estudos sobre o Estado, partidos e participação dos trabalhadores na conjuntura da guerra e do pós-guerra imediato (1942-1948). Campinas: Unicamp/IFCH, (Dissertação de Mestrado), 1981.

ALMEIDA JR., A. M. de. Do declínio de Estado Novo ao suicídio de Getúlio Vargas. In: FAUSTO, B. (org.). História Geral da Civilização Brasileira. São Paulo: Difel, vol. 10, 1981.

ALMEIDA. L. F. R. de. Insistente desencontro: o PCB e a revolução burguesa no período 1945-1964”. In: MAZZEO, A. C.; LAGOA, M. I. Corações Vermelhos: os comunistas brasileiros no século XX. São Paulo: Cortez, 2003.

ALMINO, J. Os democratas autoritários: liberdades individuais, de associação política e sindical na Constituinte de 1946. São Paulo: Brasiliense, 1980.

BARATA, A. Vida de um Revolucionário (memórias). Rio de Janeiro: Editora Melso, 1968.

BARROS, J. D’A. O Campo da História. Petrópolis: Editora Vozes, 2004.

. História Política: Dos Objetos Tradicionais ao Estudo dos Micropoderes, do Discurso

e do Imaginário". In: Educere et Educare. Revista de Educação, ano 4, nº1. Cascavel: Unioeste, 2009.

BASBAUM, L. Uma vida em seis tempos (memórias). São Paulo: Alfa Ômega, 1976.

BRANDÃO, G. M. A esquerda positiva. As duas almas do Partido Comunista - 1920/1964. São Paulo: Editora Hucitec, 1997.

. A ilegalidade mata: o Partido Comunista e o sistema partidário (1945-64). Revista Brasileira de Ciências Sociais, São Paulo, n.33, pp. 23-34., 1997 b. 
BRANDÃO, O. Agrarismo e Industrialismo: Ensaio marxista-leninista sobre a revolta de São Paulo e a guerra de classes no Brasil - 1924. São Paulo: Editora Anita Garibaldi, 2006. . Combates e Batalhas. São Paulo: Alfa Ômega, 1978.

BERSTEIN, S. Os Partidos. In: REMOND, R. (Org.). Por uma história política. Rio de Janeiro: FGV, 2003.

Culturas políticas e historiografia. In: AZEVEDO, C. et al. Cultura Política, Memória e Historiografia. Rio de Janeiro: FGV Editora, 2009.

BEZERRA, G. Memórias. Rio de Janeiro: Civilização Brasileira, 1979.

BOBBIO, N. Qual Socialismo? Discussão de uma alternativa. Rio de Janeiro: Paz e Terra, 2001.

BOGO, A. (org.). Teoria da Organização Política. Escritos de Engels, Marx, Lenin, Rosa e Mao. São Paulo: Editora Expressão Popular, vol. I, 2005.

CANALE, D. Problemas da Construção da História do Partido Comunista Brasileiro. In: Novos Rumos, ano 1, nº 1. São Paulo: Instituto Astrojildo Pereira, jan/fev/mar 1986.

CAPELATO, M. H. R. História Política. In: Revista de Estudos Históricos. vol. 9, nº17, p. 161-165. Rio de Janeiro: Fundação Getúlio Vargas, 1996.

CARDOSO, C. F. História e Poder: uma nova história política? In: CARDOSO, C.; VAINFAS, R. (org.). Novos domínios da história. Rio de Janeiro: Elsevier, 2012.

CARONE, E. O Estado Novo (1937-1945). São Paulo: Editora Difel, 1976.

A Internacional Comunista e as 21 condições. In: Gramsci e o Brasil, 2003. Disponível em: $<$ http://www.acessa.com/gramsci/?page=visualiz ar\&id=109>. Acesso em 18, dez., 2015.

CARR, E. H. Que é a história? Rio de Janeiro: Paz e Terra, 1978.

CASTRO, H. C. Cultura Política: a tentativa de construção de um conceito adequado à América Latina. In: Revista de Estudos e Pesquisas sobre as Américas, vol. 2, nº 1, JaneiroJunho. Brasília: 2008.

CAVALCANTE, B. Certezas e ilusões: os comunistas e a redemocratização da sociedade brasileira. Rio de Janeiro: EDUFF, 1986.

CERRONI, U. Teoria do Partido Politico. São Paulo: LECH, 1982.

Para una teoria del partido político. In: Teoria Marxista del Partido Político.

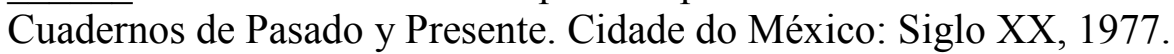

CHILCOTE, R. H. Partido Comunista Brasileira: conflito e integração. Rio de Janeiro: Edições Graal, 1982. 
Theories of Comparative Politics. Boulder: Westview Press, 1994.

COUTINHO, C. N. Gramsci. Um estudo sobre seu pensamento político. Rio de Janeiro: Civilização Brasileira, 2007.

CODATO, A.; BRAGA, M. do S. S. Robert Michels, Gramsci e a ciência política contemporânea. In: Revista de Sociologia e Politica. vol. 20, $\mathrm{n}^{\circ} 44$, Universidade Federal do Parána, Curitiba, nov. de 2012.

D'AleSSiO, M. M.; JANOTTI, M. de L. M. A Esfera do Político na Produção Acadêmica dos Programas de Pós-Graduação (1985-1994). In: Revista Estudos Históricos. vol. 9, $\mathrm{n}^{\mathrm{o}} 17$, p. 123-149. Rio de Janeiro: Fundação Getúlio Vargas, 1996.

DEL ROIO, M. O impacto da Revolução Russa e da Internacional Comunista no Brasil. In MORAES, J. Q. de (org.). História do Marxismo no Brasil. Campinas: Editora da Unicamp, vol. I, 2007.

DELGADO, L. de A. N. PTB: do getulismo ao reformismo (1945-1964). São Paulo: LTr, 2011.

DULlES, J. W. F. O Comunismo no Brasil. Rio de Janeiro: Nova Fronteira, 1985.

DUVERGER, M. Os Partidos Políticos. Rio de Janeiro: Zahar, 1970.

FALCON, F. História e poder. In: CARDOSO, C. F. S.; VAINFAS, R. (org.). Domínios da história: ensaios de teoria e metodologia. Rio de Janeiro: Campus, 1997.

FERNANDES, F. A revolução burguesa no Brasil. Rio de Janeiro: Zahar, 1974.

FERREIRA, J. Prisioneiros do Mito: cultura e imaginário político dos comunistas no Brasil (1930-1956). Niterói: EdUFF, 2002.

A democratização de 1945 e o movimento queremista. In: ;; DELGADO, L.

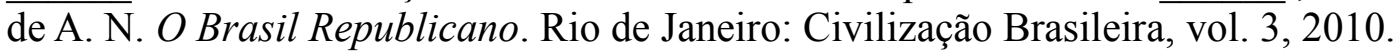

.; DELGADO, L. de A. N. (Org.). O Brasil Republicano. Rio de Janeiro: Civilização Brasileira, vol. 3, 2007.

FERREIRA. P. R. O Conceito de Revolução na Esquerda Brasileira (1920-1946). Londrina: Editora da UEL, 1999.

FICO, C. O Brasil no Contexto da Guerra Fria: Democracia, Subdesenvolvimento e Ideologia do Planejamento (1946-1964). In: MOTA, C. G. Viagem Incompleta: a Experiência Brasileira (1500-2000) - A Grande Transação. São Paulo, Ed. Senac São Paulo, 2000.

FOUCAULT, M. A Microfisica do Poder. Rio de Janeiro: Graal, 2010.

GAMA NETO, R. B. A Legislação Eleitoral de 1945 e suas Consequências Políticas. Textos e Debates (UFRR), v. 01, pp. 45-50, 1995. 
GARCIA. F. C. Partidos Políticos e Teoria da Organização. São Paulo: Cortez \& Moraes, 1979.

GOMES, A. M. de C. A invenção do trabalhismo. Rio de Janeiro: Editora FGV, 3. ed., 2005.

GORENDER, J. Combate nas Trevas. A esquerda brasileira: das ilusões perdidas à luta armada. São Paulo: Ática, 1987.

O ciclo do PCB (1922-1980). In: FORTES, A. (org.). História e perspectivas da esquerda. São Paulo: Editora Fundação Perseu Abramo, 2005.

GRAMSCI, A. Cadernos do Cárcere. Rio de Janeiro: Civilização Brasileira, 1999.

. Roberto Michels e os partidos políticos. In: GRAMSCI, A. Maquiavel, a política e o Estado moderno. Rio de Janeiro: Civilização Brasileira, 1984.

HIPÓLITTO, L. PSD: de raposas e reformistas. Rio de Janeiro: Paz e Terra, 1985.

HOBSBAWM, E. Nações e Nacionalismos desde 1780. Rio de Janeiro: Paz e Terra, 1990.

. A política da identidade e a esquerda. In: NEVES, J; DIAS, B. P. (coord.). A política de muitos: povo, classe e multidão. Lisboa: Tinta da China, 2011.

. Sobre a História. São Paulo: Companhia das Letras, 1998.

IANNI, O. Pensamento social no Brasil. Bauru: Edusc, 2004.

JULLIARD, J. A Política. In: LE GOFF, J.; NORA, P. (orgs.). História - novas abordagens. Rio de Janeiro: Francisco Alves, 1997.

KONDER, L. A democracia e os comunistas no Brasil. Rio de Janeiro: Edições Graal, 1980.

LENIN, V. I. A falência da Segunda Internacional. São Paulo: Kairós Livraria e Editora, 1979.

. Carta a um camarada. In: BOGO, A. (org.). Teoria da Organização Política. Escritos de Engels, Marx, Lenin, Rosa e Mao. Vol. I. São Paulo: Editora Expressão Popular, 2005. 1999.

. Esquerdismo, doença infantil do comunismo. São Paulo: Editora Anita Garibaldi,

. Partido Proletário de Novo Tipo: a importância mundial do bolchevismo. Lisboa: Edições Avante, 1975.

Que hacer? Moscou: Editorial Progresso, 1961.

LIMONGI, F. Eleições e Democracia no Brasil: Victor Nunes Leal e a Transição de 1945. In:

Dados - Revista de Ciências Sociais. Rio de Janeiro, vol. 55, nº 1, p. 37-69, 2012. 
LÖWY, M. O marxismo na América Latina. Uma antologia de 1909 aos dias atuais. São Paulo: Editora Fundação Perseu Abramo, 3. ed., 2012.

MAZZEO, A. C. Sinfonia Inacabada: a política dos comunistas no Brasil. São Paulo: Boitempo, 1999.

MAGALHÃES, M. M. O guerrilheiro que incendiou o mundo. São Paulo: Companhia das Letras, 2012.

MAGRI, L. Problemas de la teoria marxista del partido revolucionário. In: Teoria Marxista del Partido Político. Cuadernos de Pasado y Presente. Cidade do México: Siglo XX, 1977.

MARX, K. Critica do Programa de Gotha. Coimbra: Centelha, 1975.

. O 18 Brumário de Luís Bonaparte. São Paulo: Boitempo Editorial, 2011.

1978.

.; ENGELS, F.; et al. A questão do partido. São Paulo: Kairós Livraria e Editora, . O Manifesto do Partido Comunista. São Paulo: Boitempo Editorial, 2010.

MEDEIROS, J. A atualidade de Esquerdismo, doença infantil do comunismo. In:

Um mundo a ganhar - e outros ensaios. Rio de Janeiro: Editora Multifoco, 2012.

. Das profundezas da História: Um comunista negro na Assembleia Nacional

Constituinte de 1946. Monografia. (Bacharelado em História) - Universidade de Brasília, Brasília, 2013. Disponível em:

$<$ http://bdm.unb.br/bitstream/10483/6770/1/2013_JulianoMedeiros.pdf $\geq$. Acesso em: 21, dez., 2015.

MENDONÇA, S. R.; FONTES, V. História e Teoria Política. In: CARDOSO, C.; VAINFAS, R. (org.). Novos domínios da história. Rio de Janeiro: Elsevier, 2012.

MICHELS, R. Sociologia dos partidos políticos. Brasília: Editora da UnB, 1981.

MOORE JÚNIOR. As origens sociais da ditadura e da democracia: senhores e camponeses na construção do mundo moderno. São Paulo: Martins Fontes, 1975.

MONTEIRO, C. A campanha eleitoral comunista no contexto da legalidade do PCB. In: Opsis. Vol. 12, n², pp. 91-105, Catalão: jul/dez 2012.

MORAES, J. Q. de. A evolução da Consciência Política dos Marxistas Brasileiros. In: História do Marxismo no Brasil. Campinas: Editora da Unicamp, vol. II, 2007a.

A influência do leninismo de Stalin no comunismo brasileiro. In: História do Marxismo no Brasil. Campinas: Editora da Unicamp, vol. II, $2007 \mathrm{~b}$.

MOTTA, R. S. A História Política e o conceito de cultura política. In: Anais do X Encontro Regional de História. Mariana: 1996. 
A Cultura Política na História”. In: NAPOLITANO, M.; MOTTA, R. S. Cultura política e produção cultural. Belo Horizonte: Editora da UFMG, 2013.

MUSTO, M. Trabalhadores, uni-vos! Antologia Política da Primeira Internacional. São Paulo: Boitempo Editorial, 2014.

NERES, G. M.; DEL ROIO, M. O 'novíssimo príncipe'. Gramsci e a reconstrução da teoria marxista do partido. In: Tempo de Ciência. Toledo, nº 40, vol. 20, 2013.

OLIVEIRA, P. M. Al. de. O candidato civil do PCB: a trajetória política do engenheiro Yêddo Fiúza (1930-1947). Dissertação (Mestrado em História) - Universidade Federal de Juiz de Fora, Juiz de Fora, 2012.

PACHECO, E. A formação da esquerda no Brasil. Ijuí: Editora Unijuí, 2008.

PANDOLFI, D. Camaradas e Companheiros. História e memória do PCB. Rio de Janeiro: Relume-Dumará e Fundação Roberto Marinho, 1995.

PANEBIANCO, A. Modelos de Partido: organização e poder nos partidos políticos. São Paulo: Martins Fontes, 2003.

PINHEIRO, P. S. Estratégias da Ilusão: a revolução mundial e o Brasil (1922-1935). São Paulo: Companhia das Letras, 1991.

PRESTES, A. L. Da insurreição armada (1935) à "união nacional” (1938-1945): a virada tática na política do PCB. São Paulo: Paz e Terra, 2001.

Os comunistas brasileiros (1945-1956/58): Luiz Carlos Prestes e a política do PCB. São Paulo: Editora Brasiliense, 2010.

RAMOS, F. P. História e Poder. In: Para Entender a História. ano 1, set. de 2010.

REIS, D. A luta de classes no Brasil e o PCB. São Paulo: Novos Rumos, 1983.

REIS FILHO, D. A revolução faltou ao encontro: os comunistas no Brasil. São Paulo: Brasiliense, 1990.

2014.

Prestes: um revolucionário entre dois mundos. São Paulo: Companhia das Letras,

REMOND, R. (org.). Uma história do Presente. In: . (org.). Por uma história política. Rio de Janeiro: FGV, 2003.

. Do Político. In: . (org.). Por uma história política. Rio de Janeiro: FGV, 2003. Por que História Política?. In: Revista Estudos Históricos, vol. 7, n 13, p. 8-19. Rio de Janeiro: CPDOC/FGV, 1994.

RENÓ, L. Teoria da Cultura Política: vícios e virtudes. In: $B I B, N^{\circ} 45,1^{\circ}$ sem., p. 71-92. Rio de Janeiro: 1998. 
RIDENTI, M. O fantasma da Revolução. São Paulo: Editora da Unesp, 2010.

RODRIGUES, L. M. O PCB: Os dirigentes e a organização. In: FAUSTO, B. (dir.). História Geral da Civilização Brasileira. Rio de Janeiro: Bertrand Brasil, vol. III, tomo 10, 1997.

ROSA, M. C. C. Conceito de Partido Político Moderno. In: Revista Mediações. Londrina: vol. $1, \mathrm{n}^{\mathrm{o}} 2$, p. 65-69, 1996.

RUY. J. C. Luta de Classes na Constituinte de 1946. In: OLIVEIRA, P. de. Perfis Parlamentares: João Amazonas. Brasília: Edições Câmara dos Deputados, nº 57, 2011.

SANTANA, M. A. Homens Partidos: comunistas e sindicatos no Brasil. São Paulo: Boitempo Editorial, 2001.

SILVA, F. T.; SANTANA, M. A. O equilibrista e a política: o 'Partido da Classe Operária' (PCB) na democratização (1945-1964). In FERREIRA, J.; REIS, D. A. (org.). Nacionalismo e Reformismo Radical (1945-1964). Rio de Janeiro: Civilização Brasileira, 2007.

SILVA, H. 1944: o Brasil na guerra. Rio de Janeiro: Civilização Brasileira, 1974.

SEGATTO, J. A. Reforma e Revolução. As vicissitudes políticas do PCB (1954-1964). Rio de Janeiro: Civilização Brasileira, 1995. . Breve História Politica do PCB. Belo Horizonte: Oficina de Livros, 1989.

SOARES, G. A. D. A democracia interrompida. Rio de Janeiro: Editora FGV, 2001.

SODRÉ, N. W. Contribuição à história do PCB. São Paulo: Global Editora, 1984.

SOUZA, M. do C. C. de. Estado e Partidos Politicos no Brasil (1930-1946). São Paulo: Alfa Ômega, 1976.

STÁLIN, J. Fundamentos do Leninismo. Lisboa: Editorial Estampa, 1975.

TROTSKY, L. Bolchevismo e Stalinismo. In: MARX, K.; ENGELS, F.; et al. A questão do partido. São Paulo: Kairós Livraria e Editora, 1978.

VIANA, S. B. Política econômica externa e industrialização: 1946-1951. In: ABREU, M. (org), A Ordem do Progresso: Cem Anos de Política Econômica Republicana 1889-1989. Rio de Janeiro: Editora Campus, 1990.

VIANNA, L. W. Liberalismo e Sindicatos no Brasil. Rio de Janeiro: Paz e Terra, 1978.

VILlA, M. A. História das Constituições Brasileiras. São Paulo: Editora Leya, 2011.

VINHAS, M. O Partidão: a luta por um partido de massas (1922-1974). São Paulo: Hucitec, 1982. 
VIZENTINI, P. G. F. A Guerra Fria. In: REIS FILHO, D. A.; FERREIRA, J.; ZENHA, C. (org.). $O$ século $X X$ - O tempo das crises: revoluções, fascismos e guerras. $3^{\mathrm{a}}$ ed., Rio de Janeiro: Civilização Brasileira, p. 195-225, 2005.

WEFFORT, F. Democracia e Movimento Operário: algumas questões para a história do período 1945/1964. In: Revista da Cultura. vol. 1, nº 1, ago. 1979. 